UNIVERSIDADE DE SÃO PAULO

FACULDADE DE FILOSOFIA, LETRAS E CIÊNCIAS HUMANAS DEPARTAMENTO DE LETRAS CLÁSSICAS E VERNÁCULAS

PROGRAMA DE LITERATURA BRASILEIRA

\title{
FRATURAS NO OLHAR: REALIDADE E REPRESENTAÇÃO EM CORNÉLIO PENNA
}

André Luis Rodrigues 
UNIVERSIDADE DE SÃO PAULO

FACULDADE DE FILOSOFIA, LETRAS E CIÊNCIAS HUMANAS

DEPARTAMENTO DE LETRAS CLÁSSICAS E VERNÁCULAS

PROGRAMA DE PÓS-GRADUAÇÃO EM LITERATURA BRASILEIRA

\title{
FRATURAS NO OLHAR: REALIDADE E REPRESENTAÇÃO EM CORNÉLIO PENNA
}

\author{
André Luis Rodrigues
}

Tese apresentada ao Programa de Pós-Graduação em Literatura Brasileira, do Departamento de Letras Clássicas e Vernáculas da Faculdade de Filosofia, Letras e Ciências Humanas da Universidade de São Paulo, para obtenção do título de Doutor em Letras.

Orientador: Prof. Dr. Alcides Celso de Oliveira Villaça 


\section{AGRADECIMENTOS}

Entre o início e o término de um trabalho como este, entre as incertezas da escolha, a errância das intuições e a imprecisão das idéias - passando depois por um sem-número de fases intermediárias - até o trabalho concluído, embora nunca inteiramente pronto, entre uma e outra coisa há sempre e inevitavelmente um intervalo, não necessariamente negativo, pois que às vezes é resultado da opção consciente por novos caminhos e impensadas veredas. Haverá perdas, contudo, que independeram do desejo do desvio e darão origem a maiores ou menores lacunas que se queria a todo custo evitar. Explicações para alguns desses grandes e pequenos hiatos não devem faltar, mas torna-se muito difícil expressá-las sem que essa expressão se assemelhe a um pedido de desculpas. Assim, melhor nem falar nisso. Por outro lado, não há como não pensar que aquele intervalo poderia ser muito maior, arriscado mesmo a se tornar em grande abismo. Se isso não se deu - e não cabe a mim julgar -, foi devido também e principalmente a algumas pessoas e instituições que passo a nomear. A elas o meu muito obrigado.

Ao Alcides Villaça, que generosamente me acolheu no mestrado e agora no doutorado, pela orientação dedicada, pela presença amiga e pelas conversas prazerosas, aquelas sobre trabalho e as jogadas fora. A Ayde Veiga Lopes, que veio a se revelar uma conhecedora ímpar da obra de Cornélio Penna, com quem pude também dialogar com enorme proveito. Aos professores Lúcia Helena de Oliveira Vianna, Benedito Antunes, Elias Thomé Saliba e Vagner Camilo, pelas diferentes leituras desta tese todas sensíveis, cuidadosas e críticas no melhor sentido - e pelo diálogo fecundo, pleno de observações e sugestões importantíssimas para a continuidade de um trabalho que é sempre interminável. Aos professores Ariovaldo José Vidal e, novamente, Elias Thomé Saliba, pela leitura atenta e problematizadora do relatório de qualificação, bem como pelas diversas sugestões e comentários enriquecedores. À professora Yudith Rosenbaum, pelo curso da pós-gradução sobre a literatura de Clarice Lispector, verdadeiramente instigante e proveitoso. Ao professor Nicolau Sevcenko, também por um curso da pós-graduação, no Departamento de História, de que pude participar como ouvinte, sobre "cultura popular", em aproximação sempre muito original e bastante fecunda. Ao professor Marcos Vinicius Mazzari, pela oportunidade de assistir a algumas aulas de seu curso de pós-graduação, ambicioso e inspirador, sobre Fausto e o 
tema do pacto, e pela presença sempre amiga e prestativa. Ao prof. Murilo Marcondes Moura, pelas conversas francas e agradáveis, sobre a literatura e a vida, em que invariavelmente acabo por aprender algo novo. Ao prof. Vagner Camilo, também pela empatia que nunca deixou de demonstrar quando casualmente nos encontrávamos, não se esquecendo de dizer uma palavra encorajadora sobre o trabalho com Cornélio ou de fazer um valioso comentário sobre o escritor.

Aos meus amigos e colegas em algum momento ligados à Universidade e à pósgraduação, José Hélder Pinheiro Alves, professor da Universidade Federal de Campina Grande, Ieda Lebensztayn, Alexandre Koji Shiguehara, Maria Claudete de Souza Oliveira, Ana Luíza Reis Bedê, Maria Rejane Araújo Tito, César Mota Teixeira, Mário Alex Rosa, Cristiane Rodrigues, Simone Rossinetti Rufinoni, Adriana Morelli, Luciane Colucci Alves, Maristela Reggiani, Maria Salete Magnoni, Ismara Izepe de Souza e Maria do Carmo Malheiros, por diferentes sugestões, textos ou livros indicados ou dados como presente, verdadeiro dom, pela revisão da versão em inglês do resumo ou simplesmente pela pergunta interessada "como vai o trabalho?", por tudo que de algum modo tenha se materializado aqui, sem que eventualmente venham a se dar conta disso, pelo diálogo e pelo convívio que talvez pudessem ter sido mais freqüentes não fossem muitas vezes a distância e o envolvimento de cada um com seu trabalho.

Aos funcionários da Biblioteca e do Arquivo-Museu de Literatura Brasileira da Fundação Casa de Rui Barbosa e particularmente à profa. Eliane Vasconcellos, que o chefia, que tão bem me receberam e de modo tão prestativo e gentil. Ao dr. Fernando de Queirós Mattoso, que também de maneira muito cortês atendeu prontamente o pedido de um desconhecido, vindo de São Paulo ao Rio de Janeiro, autorizando-o a reproduzir boa parte do acervo de Cornélio Penna junto à Casa de Rui Barbosa, bem como à sra. Neila, sua secretária. Aos funcionários da Biblioteca do Instituto de Estudos da Linguagem da Unicamp e aos funcionários da Biblioteca Florestan Fernandes, da FFLCH / USP.

À CAPES, pela bolsa concedida, pois sem esse apoio a realização deste trabalho seria muito mais difícil.

Por fim, um agradecimento especial a Elena Pajaro Peres e Nelson Aprobato Filho. Quaisquer palavras em relação à importância de um e de outro nesses últimos anos, do ponto de vista intelectual e de vida, não expressariam de modo algum a dívida enorme que existe e que nunca poderá ser paga. Dos tempos do "Deviração" aos nossos 
encontros informais, uns como outros abertos à discussão de idéias e ao riso, nosso convívio foi fundamental para que eu pudesse realizar este trabalho.

E como não poderia deixar de ser, a Lígia Yuri Ono Rodrigues e a Mitiko Ono deixo aqui um muito obrigado por tudo que me proporcionaram nesses últimos anos de trabalho árduo e um pedido de desculpas pela ausência, pela presença ausente e pela presença ultimamente um pouquinho irritada... 


\section{RESUMO}

Esta abordagem da obra de Cornélio Penna compreende uma leitura dos quatro romances por ele publicados - Fronteira, em 1935; Dois romances de Nico Horta, em 1939; Repouso, em 1948; e A menina morta, em 1954 - que intenta refletir sobre alguns de seus aspectos fundamentais, como o estranhamento e a incomunicabilidade, a loucura e a morte, a sexualidade e a transgressão, a projeção da intimidade nas coisas e a natureza hostil voltada contra o homem, as crenças e superstições, o fatalismo e a herança irrecusável do passado, o mobiliário antigo e as velhas casas habitadas por espectros e fantasmas, e especialmente a condição do negro e a escravidão. Busca-se estudar também as inter-relações entre esses e outros motivos que atravessam toda a sua produção romanesca - ambientada numa Itabira atemporal na região montanhosa de Minas Gerais, nas três primeiras obras, e em uma grande propriedade produtora de café com o uso de mão-de-obra escrava, no Vale do Paraíba, na última - e a linguagem do escritor e a forma dos romances, de modo que as tensões, as alternâncias, as inversões, os paradoxos e mesmo eventuais incongruências possam ser vistos de algum modo como homólogos às divisões do sujeito, agravadas na primeira metade do século XX, entre outras coisas, pela acelerada expansão do sistema capitalista ainda que (ou sobretudo) num país periférico, e pelos choques que nele se dão entre modernidade e atraso, entre civilização e barbárie. O olhar de um artista cindido, o pintor como o escritor, capta um homem e um mundo também fraturados, e a forma e temática de suas obras trazem inscritas tais fissuras. Ainda quando pareça furtar-se à dramatização do próprio tempo, a obra corneliana é representação, não no sentido da mímesis vista como imitatio, mas como diferença, como o que se põe em relação tensa com a realidade. Para melhor entender o contexto em que se dão essas fraturas, indaga-se a respeito da personalidade do escritor, monarquista e católico, e das dicotomias de então, notadamente aquelas que marcaram as décadas de 20 e 30, o que é feito, em grande medida, a partir do confronto entre o pensamento de Tristão de Athayde e o de Sérgio Buarque de Holanda. Por fim, esboça-se alguma reflexão sobre o significado da produção corneliana em seu tempo e em nossos dias.

\section{PALAVRAS-CHAVE:}

\section{Romance, Literatura Brasileira, Modernidade, representação, realidade}




\section{ABSTRACT}

This approach to Cornélio Penna's works comprehends four novels published by the author - Fronteira, in 1935; Dois romances de Nico Horta, in 1939; Repouso, in 1948; and A menina morta, in 1954 - and tries to reflect on some of their fundamental aspects, such as estrangement and incommunicability, madness and death, sexuality and transgression, projection of intimacy on things and hostile nature against man, beliefs and superstitions, fatalism and the irrecusable legacy of the past, old furniture and old houses inhabited by phantoms and ghosts, and above all, the condition of black people and slavery. Also investigated are interrelationships between these and other motives that permeate his novels - set in a timeless Itabira in the Minas Gerais mountains (the first three novels), and in a large Vale do Paraíba coffee plantation tilled by slaves (the last novel) - and the author's language, and the form of novels, so that tensions, alternations, inversions, paradoxes, and even occasional incongruences can be somehow regarded as homologues to the divisions of the subject, which are aggravated in mid20th century by, among other things, the accelerated expansion of the capitalist system even (or above all) in a peripheral country, and the shocks between modernity and backwardness, civilization and barbarity. The glance of a divided artist, the painter as well as the writer, captures a man and a world that are also fractured, and the form and themes of his works also show such fissures. Even when it seems to escape the drama of time itself, the Cornelian novel is representation not in the sense of mimesis seen as imitatio, but as difference, something in tense relationship with reality. In order to better understand the context in which such fractures occur, one queries the writer's personality, a Catholic monarchist, and the dichotomies of his time, particularly those that marked the 1920s and the 1930s, as shown to a large extent in the confronting ideas of Tristão de Athayde and Sérgio Buarque de Holanda. Finally, some reflection is undertaken on the meaning of the Cornelian production to his day and to our time.

\section{KEY WORDS:}

Novel, Brazilian literature, modernity, representation, reality 


\section{SUMÁRIO}

1. DOIS MUNDOS E DOIS PONTOS DE VISTA: CORNÉLIO PENNA E SEU TEMPO 08

1.1. Dissonâncias e contrastes reveladores; tons e entretons 09

1.2. Perspectivas: Sérgio e Tristão 25

2. CAMINHOS E DESCAMINHOS EM MEIO ÀS MONTANHAS: OS DOIS MUNDOS DE ITABIRA EM TRÊS ROMANCES CORNELIANOS 42

2.1. $O$ candeeiro e a lâmpada elétrica 43

2.2. Entre o campo e a cidade 70

2.3. Círculo mágico: encantamento e dissolução 85

3. DAS MONTANHAS DE ITABIRA AO VALE DO PARAÍBA: O NEGRO EM PRIMEIRO PLANO 115

3.1. A figuração do negro de Fronteira a Repouso 116

3.2. O escravo, o agregado, o proprietário e as meninas mortas 123

4. FRATURAS NO OLHAR: REALIDADE E REPRESENTAÇÃO EM

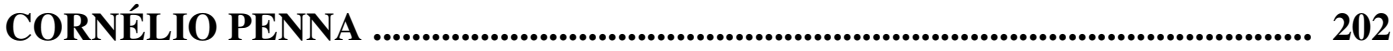

4.1. Fraturas no olhar: realidade e representação em Cornélio Penna ................ 203

4.2. O romance corneliano em seu tempo e depois ................................................ 248

REFERÊNCIAS BIBLIOGRÁFICAS ......................................................................... 257

Reprodução de imagens do acervo de Cornélio Penna - Arquivo-Museu de Literatura Brasileira - Fundação Casa de Rui Barbosa, a partir de cópias fotográficas digitais (seis páginas, não numeradas, em papel especial) 268 


\section{DOIS MUNDOS E DOIS PONTOS DE VISTA: CORNÉLIO PENNA E SEU TEMPO}

Estaríamos vivendo assim entre dois mundos: um definitivamente morto e outro que luta por vir à luz.

Sérgio Buarque de Holanda

Cornélio parecia um homem desembarcado por engano neste planeta.

Murilo Mendes 


\subsection{Dissonâncias e contrastes reveladores; tons e entretons}

Que encanto encontrei nesse homem do qual tantos motivos me separavam,

esse Cornélio Pena monarquista que ouvia música somente em caixinhas de música; que odiava a poesia e os poetas, a arte moderna, o cinema; cujo pintor preferido era a baronesa de Paraná;

esse homem insociável, que não gostava de fazer nem de receber visitas; que não usava colaborar em jornais; que não respondia a cartas.

(...)

Cornélio parecia um homem desembarcado por engano neste planeta. Num século que pretende nivelar em tom cinzento a indistinta massa humana, ele pertencia ao número dos que representam algo de excepcional.

Sofrendo de estrabismo convergente, seus olhos litigavam entre si e com o interlocutor; o riso sarcástico, de alguém que sabe aplicar com muita precisão os seus adjetivos. Feria rindo. A voz parecia sair de um gramofone fanhoso, "a voz das coisas que o cercavam".

Essas coisas eram objetos "antigos". (Como são recentes essas nossas antiguidades!) A cada um, fosse um móvel, um leque, um bastão, uma salva de prata, atribuía uma história particular, um significado próprio. (...)

(...)

Assim eram as insólitas reações de Cornélio Pena: homem qualitativo num mundo quantitativo, homem que noivava diante do Santíssimo Sacramento exposto, e que sofrera a influência do forte charme de Itabira do Mato Dentro, cidade onde só passara um período da infância.

("Cornélio Pena", Murilo Mendes, Transístor, pp. 164-5)

Coube ao poeta, munido de sua grande sensibilidade e notável capacidade de expressão, compor a imagem tão concentrada e precisa do contraste entre a personalidade desse homem estranho ${ }^{1}$ e a natureza do estranho mundo em que ele vivia: "homem qualitativo num mundo quantitativo". E a atitude desse homem diante desse mundo só podia ser de recusa, de negação de seu tempo, do tempo presente. O mundo,

\footnotetext{
${ }^{1}$ Nas palavras de Adonias Filho, o "grande e estranho romancista". (Cornélio Pena - romance, p.10)
} 
porém, ainda que com algum atraso, paga na mesma moeda, recusando um lugar ao escritor. Tornou-se quase um lugar-comum dizer do "sem-lugar" da obra de Cornélio Penna e do próprio escritor no panorama da literatura brasileira, de um lado, e da ficção dos "anos 30", de outro. Isso em geral para aqueles poucos que conhecem e admiram a sua obra, e que o fazem como o elogio dessa singularidade ${ }^{2}$. A expressão utilizada por assim dizer num sentido próprio pode igualmente aludir ao esquecimento que tal obra vem sofrendo, com raras exceções, seja nas livrarias e bibliotecas, seja nos ensaios da crítica ou nos estudos e trabalhos acadêmicos, lugares em que Cornélio Penna quase não tem lugar. Seus romances só foram recentemente reeditados porque uma estudiosa, Maria Helena Alves, apaixonada por eles, decidiu-se a abrir em 1996 uma editora, a Artium $^{3}$, tão-somente para esse fim. Contudo, em menos de dez anos estavam todos esgotados e a editora, ao que parece, fechada. Embora as boas obras de referência não deixem de mencioná-la, ressaltando inclusive a sua qualidade, a produção acadêmica sobre a obra de Cornélio Penna é mínima se comparada àquela dedicada a outros importantes escritores do período. A recepção crítica dessa obra, a despeito de seu indiscutível valor, também não é muito extensa, e em larga medida concentrada ao longo da publicação de seus romances, entre os anos de 1930 e 1950. É durante esse período e até a sua morte, contudo, que esse escritor, hoje praticamente desconhecido, é considerado pela crítica e pela imprensa em geral como um dos maiores escritores brasileiros ${ }^{4}$.

\footnotetext{
${ }^{2}$ É ainda Adonias Filho, um dos maiores admiradores de Cornélio Penna, quem afirma: "Ignorando o que possa ter acontecido, quer como movimentação social, quer como renovação artística, associa ao caminho iniciado com Fronteira a preocupação literária dêste Repouso - à margem do tempo, pois permanece o mais singular dos modernos romancistas brasileiros." ("O Coração violado", Modernos ficcionistas brasileiros, p. 29) E Fausto Cunha, em seu excelente ensaio sobre a obra corneliana, exprime praticamente a mesma idéia com outras palavras: "A citação de um Octavio de Faria, de um Lúcio Cardoso ou de Graciliano Ramos não impede que se reconheça a solidão quase absoluta de Cornelio Penna, ..." ("Forma e criação em Cornelio Penna", Situações da ficção brasileira, p. 124)

${ }^{3} \mathrm{Na}$ edição de Fronteira, publicada em 2001, consta uma nota informando que desde 1996 a editora vem tentando encontrar o herdeiro ou herdeiros da obra de Cornélio Penna sem sucesso e que continuariam envidando esforços nesse sentido, o que não deixa de ser mais um dado inquietante sobre o vazio que circunda a história da vida e da obra do escritor.

${ }^{4}$ No prefácio para a nova edição de sua obra fundamental sobre o romance corneliano, Luiz Costa Lima alude à dificuldade de se comprovar hoje a consagração que Cornélio Penna teria tido em vida, desde o lançamento de Fronteira até a publicação de A menina morta, o que é mencionado por mais de um crítico. Essa comprovação é mesmo muito difícil, mas torna-se possível por meio de consulta ao acervo do escritor junto à Fundação Casa de Rui Barbosa, em que se pode ter acesso a três grossas pastas com recortes de jornal cuidadosamente organizados, trabalho que deve ter sido realizado pela esposa de Cornélio. Ali pode ser vista enorme quantidade de artigos elogiosos à obra corneliana (segundo um deles, "das mais poderosas e originais de nossa ficção contemporânea"), como inúmeras matérias, nos mais diversos jornais do país, quando da morte do escritor, lamentando-a e referindo-se a ele como "o grande romancista", "um de nossos maiores romancistas"; "uma das maiores figuras de nossa ficção contemporânea" ou "um dos mestres da literatura de introspecção". No jornal Correio da Manhã, do dia
} 
Curiosamente ou sintomaticamente, a vida de Cornélio Penna foi sempre marcada, se não pela falta de lugar, pela experiência do deslocamento constante ${ }^{5}$, sendo o escritor em diversos aspectos um exemplo muito adequado daqueles "primos pobres" tão bem caracterizados por Sérgio Miceli' ${ }^{6}$. Nascido em Petrópolis, em 1896, muda-se com a família para Itabira, Minas Gerais, em 1897, e apenas um ano depois, com a morte do pai, mãe e filhos acabam novamente se mudando, desta vez para Pindamonhangaba, no interior de São Paulo, onde viviam alguns parentes (antes disso, a mãe do escritor havia se dirigido com os filhos ao Rio de Janeiro na expectativa de viver na companhia da mãe, mas ao chegar à cidade toma conhecimento de que ela acabara de falecer). Em 1900, voltam novamente a morar em Itabira, residindo em diversas casas, e depois de um ano retornam a Pindamonhangaba, para em seguida se estabelecerem em Campinas. No final de 1913, Cornélio muda-se com a família para a capital, e no ano seguinte ingressa na Faculdade de Direito do Largo de São Francisco. Terminada a faculdade em 1919, sem esperar o resultado dos exames, acreditando que havia sido reprovado numa das matérias, o que só muito depois se mostrará um equívoco, muda-se para a casa de um irmão em Niterói e passa a trabalhar como ilustrador e redator em dois periódicos no Rio de Janeiro, $O$ Combate e $A$ Razão, e algum tempo depois em $O$ Jornal, em que teria publicado desenhos, crônicas e contos. Durante alguns anos, porém, vive ainda alternadamente entre o Rio e São Paulo até entrar para o Ministério da Justiça e fixar residência em Niterói, a partir de 1925, e depois em Botafogo, no Rio de Janeiro, em 1927.

A atividade artística começara com a pintura, tendo se descoberto pintor aos onze anos de idade, mas é só muitos anos depois, em 1923, que expõe pela primeira vez alguns quadros seus, no Salão da Primavera. Em 1928, realiza com sucesso a primeira exposição individual, no Saguão dos Empregados do Comércio. Pouco tempo havia se passado, porém, quando, ao terminar de pintar um belíssimo quadro intitulado "Anjos combatentes", decide desistir da pintura, embora continue produzindo por mais alguns

15/10/55, na seção "Escritores Brasileiros Contemporâneos", dedicada naquela ocasião a Cornélio Penna, Renard Perez afirma ser o escritor "o representante máximo de nosso romance introspectivo e talvez tenha sido Fronteira a mais expressiva estréia de literatura brasileira de todos os tempos."

5 A maior parte dos dados biográficos a que tive acesso foi retirada da pequena biografia do escritor escrita por Renard Perez, feita a partir, creio, dos dados colhidos em 1955, incluída em Escritores brasileiros contemporâneos, e do depoimento do próprio Cornélio a Ledo Ivo, publicado em $O$ Jornal, em 1948, e reproduzido nos Romances completos, da editora Aguilar, de 1958, bem como de entrevistas e artigos do acervo do escritor junto ao Arquivo-Museu de Literatura Brasileira da Fundação Casa de Rui Barbosa.

${ }^{6}$ Intelectuais à brasileira. 
anos, sobretudo ilustrações para a publicação de livros escritos por amigos. O motivo alegado mais tarde é que fazia "literatura desenhada" ou "literatura pintada". Há entretanto outras motivações: em sua algo patética "Declaração de insolvência", publicada em A Ordem, em junho de 1929, critica o isolamento a que são relegados os artistas plásticos no Brasil e afirma o nosso maior "adiantamento literário". Quaisquer que sejam os motivos, uma tal desistência é no mínimo surpreendente, se considerarmos o relativo sucesso da exposição individual e a alta conta em que era tida sua produção pictórica. De fato, a despeito do estado relativamente precário de boa parte dos desenhos e pinturas que se encontram no acervo junto à Fundação Casa de Rui Barbosa $^{7}$, eles ainda impressionam. De qualidade diversa, certamente produzidos em momentos muito distintos e para diferentes fins - a maior parte constituída de estudos, esboços e obras inacabadas -, alguns são absolutamente notáveis e não é por acaso que deram origem a textos tão inspirados como aquele do contemporâneo Murilo Araújo ${ }^{8}$ e, mais recentemente, o belo ensaio de Alexandre Eulálio ${ }^{9}$. Da proclamação da desistência da pintura até a edição do primeiro romance, passaram-se seis anos: em 1935, Cornélio Penna publica Fronteira, e depois disso publicará apenas outros três romances, a relativamente longos intervalos, até sua morte em 1958: Dois romances de Nico Horta, em 1939; Repouso, em 1948; e A menina morta, em $1954^{10}$. Deixará ainda fragmentos de um romance inacabado - Alma branca.

Um ano depois da publicação do primeiro livro, Cornélio Penna é nomeado Diretor do Instituto de Artes da Universidade do Distrito Federal, e em 1938, VicePresidente da Sociedade Brasileira de Belas-Artes, para o período 1938/39, embora já tivesse abandonado definitivamente a pintura pelo menos desde 1935, quando ele mesmo se encarregara das ilustrações para a edição de Fronteira. O acervo do escritor

\footnotetext{
${ }^{7}$ Que fique bem claro: não por qualquer descuido na conservação do acervo, que ao contrário parece muito bem cuidado. Esse estado deve ter se originado durante a própria vida do escritor, que mantinha seus trabalhos no "desvão da escada" de sua residência, local a que se referia como "necrotério". Ledo Ivo, convidado a vê-los, alude aos "quadros que tão comentados foram, há anos, com suas linhas atormentadas, bizarras, de um colorido ainda vivíssimo e estranho". (p. LXI)

8 "O gênio macabro de Cornélio Penna", in: Romances completos, p. 1317-21.

9 "Os dois mundos de Cornélio Penna", in: Escritos, p. 443-63. Muito tempo depois de ter tomado conhecimento desse estudo é que fui descobrir ter sido ele composto para fazer parte do catálogo da exposição realizada em 1979 na Fundação Casa de Rui Barbosa, que incluía manuscritos, documentos, objetos pessoais, desenhos e pinturas de Cornélio Penna, quando de sua doação à Fundação pela esposa do escritor, Dona Maria Odília de Oliveira Penna. Essa "descoberta" só foi possível graças à gentileza da profa. Eliane Vasconcelos, chefe do Arquivo-Museu de Literatura Brasileira da Fundação Casa de Rui Barbosa, que generosamente forneceu-me uma cópia desse precioso catálogo.

${ }^{10}$ Todas as citações da obra de Cornélio Penna ao longo do presente trabalho foram retiradas das edições da Artium, que constam da Bibliografia ao final do texto; em caso contrário, as referências serão explicitamente mencionadas em notas de rodapé.
} 
na Fundação Casa de Rui Barbosa contém também, entre outros documentos, um abaixo-assinado a ele dirigido para que não se exonerasse da direção do Instituto, datado de março de 1936, contendo, dentre outras, as assinaturas de Andrade Muricy, Candido Portinari, Carlos Leão, Sylvia Meyer, Gilberto Trompowsky, Villa Lobos, Adelino Magalhães e João Condé. Tendo permanecido por apenas dois meses à frente do Instituto, que motivos o teriam levado ao pedido de exoneração? O fato é que Cornélio resolveu ficar. A edição dos Romances completos traz uma fotografia tirada durante um almoço no "Automóvel Clube", em outubro de 1937, em homenagem ao Diretor do Instituto de Artes da Universidade do Distrito Federal, Cornélio Penna. E uma correspondência do início de 1938, enviada pela comissão de festas dos formandos de 1937 da Universidade do Distrito Federal, comunica-lhe que resolveram homenageá-lo "por ocasião das suas festas de formatura", enquanto um outro comunicado, assinado pelo então reitor Alceu Amoroso Lima, informa-lhe ter sido designado para a presidência da banca de exames de História da Arte para o concurso de habilitação aos cursos da Universidade no ano de 1938.

Ao publicar seu segundo romance, Cornélio Penna encontrava-se numa situação de estabilidade como nunca talvez conhecera. A impressão é que finalmente cessara o ciclo de mudanças que sempre caracterizou sua vida. Contudo, em 1941, resolve simplesmente abandonar o emprego no Ministério da Justiça, ao que parece depois de ter recebido "algumas heranças"11, e volta para São Paulo, passando a viver em companhia da mãe até a morte dela em 1943. A ligação que o filho tinha com ela seria muito forte, e parece-me que é à sua perda que Cornélio irá um dia aludir ao mencionar a "maior escuridão que os pobres seres humanos podem enfrentar" e o "vácuo que se abriu diante" dele, mas que por fim conseguiu ultrapassar. Ainda em 1943, retorna ao Rio de Janeiro e, aos 47 anos de idade, casa-se com Maria Odilia de Queiroz Matoso.

A sua vida teria sido caracterizada desde a infância pelo solipsismo: "era uma criança solitária, inquieta, mas só interiormente, que não sabia brincar, e passava a maior parte de meu tempo em duas salas vazias, com os brinquedos diante de mim, a

\footnotetext{
${ }^{11}$ A informação é dada por Afonso F. Schmidt em depoimento citado por Luiz Costa Lima (op. cit., p. 11), em que o poeta se refere igualmente à "libertação" do Ministério de Justiça que teria se seguido ao recebimento dessas heranças. Afirma, contudo, que isso teria ocorrido em 1937 e não em 1941. De fato, no acervo de Cornélio consta cópia do testamento de Zeferina Marcondes Carneiro Leão, Baronesa do Paraná, em que ela deixa ao escritor quatro prédios na Praia de Botafogo, ao pé do morro da Viúva, datado de outubro de 1936.
} 
imaginar o que devia se passar com êles..."12 E na época do ginásio, quando perdeu uma das vistas:

Vivia um pouco afastado dos colegas, sem amigos, mas já nesse tempo a vida me ensinara rudemente os seus perigos, pois aos dez anos feri a vista direita, e perdi tôda a visão, e daí o meu martírio de criança, proibido de ler, e ouvindo através da porta de meu quarto, a recomendação ansiosa: - Apague a luz, que você fica cego... ${ }^{13}$

Essa situação não se altera em absoluto na vida adulta, bem ao contrário vai dar origem e tornar mais disseminada com o tempo a imagem de reservado, misterioso e intratável ${ }^{14}$ que Cornélio carregou ao longo de sua vida. No caso dos meios literários, apesar da amizade com diversos escritores e intelectuais, como Lúcio Cardoso, Marques Rebelo, Murilo Mendes e Adonias Filho, a reserva a que se votou foi mais do que consciente:

Não se pode imaginar o verdadeiro horror que tenho de viver artificialmente, de criar sem sentir um personagem, e depois ficar prisioneiro dêle, e ter de tomar atitudes literárias, de viver literàriamente. Não me cabe êsse papel e não sei representá-lo, e fico humilhado quando me prendo a dizer coisas artísticas... Vivo apenas a minha vida, e acho tão difícil, tão complicado o vivê-la, já me sinto tão cansado, só com isso, que o isolamento para mim é um refúgio e uma necessidade. ${ }^{15}$

Isolamento não só dos homens como do próprio tempo, na vida como na literatura, é o que parece ter sido uma busca constante por "esse homem insociável, que não gostava de fazer nem de receber visitas", "que não respondia a cartas" e "que odiava a poesia e os poetas ${ }^{16}$, a arte moderna, o cinema”. Embora tudo isso deva ser o seu tanto relativizado à medida que conhecemos um pouco mais da vida do escritor, parece inegável ao menos o desejo cada vez mais intenso de se isolar do mundo, cuja realização foi sendo conquistada gradativamente sem nunca dar-se de maneira absoluta.

\footnotetext{
${ }^{12}$ Romances completos, p. LVI.

${ }^{13}$ Id. ibid., p. LVII.

${ }^{14}$ Luiz Costa Lima se refere à "fama de espinho ambulante que acompanhava o escritor." (Op. cit., p.10)

${ }^{15}$ Romances completos, p. LXVI.

${ }^{16}$ Cabe aqui o esclarecimento de que não era absoluto esse "ódio", mas dirigido aos poetas de seu tempo: "Detesto poesia porque ela deixou de ser o canto do berço de todos os homens, a música que os acalentava e fazia adormecer as suas dores e se tornou uma 'flor da civilização'." (Depoimento a Ledo Ivo, in: Romances completos, p. XLVI)
} 
A despeito da notoriedade desse anelo, Ledo Ivo o procurou em sua residência "nova" em Laranjeiras, depois de ter descoberto in loco que ele se mudara de Botafogo, e nos deixou um depoimento da visita e da conversa que manteve com o escritor. Alguns momentos desse importante testemunho ilustram muito bem a vida retirada que Cornélio Penna levava, quase totalmente alheia aos acontecimentos mais recentes:

A casa onde reside Cornelio Penna, em Laranjeiras, dá frente para a rua, e, com a sua alta porta de madeira pintada de escuro, côr de bronze antigo, lembra logo um pequeno convento. Para essa impressão, muito contribui o estar sempre de janelas cerradas, bem como o seu ar de recolhimento e de silêncio, no meio das outras residências ruidosas e muito abertas. $\mathrm{O}$ grande vitral que nos surge logo aos olhos, com duas figuras graves, de olhar sereno, aumenta a sensação de paz e de longitude, que os móveis sombrios, os papéis de côres discretas, a grande quantidade de quadros de pinturas de tons velados e os enormes retratos de família ainda mais acentuam. Não é uma casa mobiliada com móveis antigos, é todo um ambiente que vive tranqüilo, um pouco sonolento, indiferente ao que se passa lá fora, e parece imutável. Sabíamos que esta era outra residência de Cornelio Penna, pois fôramos procurá-lo no Bairro de Botafogo, mas era impossível acreditar que aquêles sofás, aquêles tapetes, aquêles móveis preciosos de tartaruga e bronze tivessem vindo para onde estavam há poucos anos, carregados aos trambolhões pelas ruas... Ali deviam estar há muito tempo, colocados por mãos que já foram devoradas pela morte, e seria um crime retirá-los de seus lugares. (Ledo Ivo, “A vida misteriosa do romancista Cornelio Penna”, p. LIII)

Essa vida reclusa, carregada e sobrecarregada do passado, encontra correspondência numa obra que parece evitar, em grande medida, a descrição do que seria mais especificamente moderno ou modernista. Assim, se há referência em praticamente todos os romances a fotografias e a trens e locomotivas, o que é num certo sentido mais típico do século XIX do que do XX, é inútil procurarmos neles alusões a automóveis, a aviões, a arranha-céus, a conglomerados industriais, ao telefone, ao rádio, ao cinema, a sindicatos e greves, a revoluções, a bombas ou a qualquer uma das duas guerras mundiais, que Cornélio pôde acompanhar em vida, isto é, a tudo o que, tendo ou não origem no século $\mathrm{XX}$, passou a representar o que é mais característico desse, 
segundo Eric Hobsbawn, "breve século" tão mortífero ${ }^{17}$. Nenhum de seus romances é ambientado numa cidade grande ou numa capital, apesar de ter vivido a maior parte de sua vida em cidades como Campinas, São Paulo e Rio de Janeiro. Ao contrário, passamse sempre em vilas ou pequenas cidades, ou então no campo. E ainda assim, o tempo não é o presente, mas o passado, cada vez mais recuado na seqüência cronológica da publicação dos quatro romances, como notou e demonstrou com argúcia Luiz Costa Lima, a despeito da ausência neles de marcas temporais muito precisas.

Não valeria a pena indagar se não se aplica aqui o provérbio de que as aparências enganam ou pelo menos se é mesmo possível escapar ao próprio tempo e se ele não acaba se manifestando à revelia daquele que pretende a ele se furtar? Se buscou, de modo consciente ou não, representar "os valores eternos que surgiram com a última criatura - a liberdade em aceitar ou negar ou pecado, a procura da própria razão de ser do destino, a preparação para a morte, o encontro extremo com Deus"18, se pretendeu figurar a condição humana num sentido por assim dizer universal, como querem alguns de seus críticos ${ }^{19}$, não teria Cornélio representado de algum modo os homens do mundo e do tempo em que viveu? Como Balzac, conservador e monarquista, pôde compor um painel amplo e verossímil do homem do século XIX, isto é, do homem moderno, muito superior àquele de Zola - de acordo com a aguda observação de Lukács -, não poderia ter Cornélio Penna trazido para a sua obra as angústias do homem do século $\mathrm{XX}$, diferentes daquelas do homem retratado n’ A Comédia Humana (ressalvada a inevitável desigualdade entre o homem que vive no centro e aquele outro, num país periférico) apenas talvez por uma questão de grau (com o Capitalismo agora plenamente implantado e onipresente, o sobreviver inteiramente sobreposto ao viver, o quantitativo, ao qualitativo, o parecer e o ter, ao ser, o monólogo, ao diálogo, o representar, ao agir, o ruído, ao silêncio, a sociedade do espetáculo ${ }^{20}$, enfim, não muito diferente da que hoje

\footnotetext{
17 "Como comparar o mundo da década de 1990 ao mundo de 1914? Nele viviam 5 ou 6 bilhões de seres humanos, talvez três vezes mais que na eclosão da Primeira Guerra Mundial, e isso embora no Breve Século XX mais homens tivessem sido mortos ou abandonados à morte por decisão humana que jamais antes na história." (Era dos extremos: o breve século XX - 1914-1991, p. 21)

${ }_{18}$ Adonias Filho, Cornélio Pena - romance, p. 10.

19 Outros, por seu turno, embora não tenham ressaltado a historicidade da obra corneliana (diferente da representação histórica), seu caráter de obra do seu tempo, não ficaram limitados a essa visão algo restrita do universal. Sirva-nos de exemplo o ensaio curtíssimo de Haroldo Bruno sobre o escritor: "O tema dos romances do Sr. Cornelio Penna é um problema de consciência. Talvez a sua feição pessimista tenha à luz duma interpretação religiosa fundamento no pecado original, na noção de culpa que sòmente o sofrimento redime. Para nós é apenas isto: o desejo em tôda criatura realmente lúcida de achar a razão última da existência." ("Um romance de Cornelio Penna", p. 216)

${ }^{20}$ É por meio de pares antinômicos como esses que Guy Debord descreve essa sociedade, em sua obra fundamental, A sociedade do espetáculo.
} 
conhecemos), de modo quiçá também superior ao de alguns escritores que conscientemente e mesmo programaticamente pretenderam retratar esse mesmo homem, em meio aos conflitos sociais e políticos de então, naquilo que se convencionou chamar literatura social-regionalista dos anos 30? Não seria essa fuga em si mesma uma das características fundantes da modernidade, ligada de modo estreito ao sentimento de desconforto, de desamparo nesse mundo "novo"?

Ocorre que também o mundo figurado ao longo dos quatro romances contém elementos plenamente reconhecíveis no presente do escritor ou pelo menos num passado bem recente. Foi isso, aliado ao poder descritivo incomparável do escritorpintor, que fez com que Bandeira anotasse:

Só em Repouso vim aprender a decifrar a alma de uma velha cidade mineira onde morei durante um ano - Campanha, a velha Campanha da Princesa da Beira, terra de minha querida amiga Donana, cuja dolorida vivência seria um tema que só em Cornelio encontraria seu cabal romancista. ${ }^{21}$

É igualmente possível reconhecer traços da obra presentes até hoje em nossa sociedade, tanto no que se refere a vilas e lugarejos muito semelhantes ainda aos descritos por Cornélio, como ainda em diversos recantos ou meandros de nossas metrópoles, em que o arcaico insiste em sobreviver lado a lado com o que há de mais supostamente moderno ou pós-moderno. Embora não haja descrições das grandes cidades e das capitais, elas são mencionadas algumas vezes, e ora é dito que este ou aquele personagem esteve numa delas, ora que para lá se dirige. A alusão a trens e locomotivas, a fotografias e a lâmpadas elétricas em praticamente todos os romances deve nos fazer notar que o passado narrado não é nunca muito remoto, estando em alguns casos relativamente próximo do próprio tempo escritor. O mesmo pode ser dito, por exemplo, das referências à extração do minério de ferro, em Fronteira, e à chegada de um semnúmero de produtos importados da Europa, n’ A menina morta, sem contar as menções mais diretas, como a fala do juiz, em Fronteira, que faz alusão a Floriano Peixoto e à Revolta Saldanha da Gama, de que teria participado.

Se Cornélio parece de fato ter desembarcado por engano no planeta (na outra imagem feliz do poeta) ou no século, talvez seja possível pensar que a sua personalidade

\footnotetext{
21 "Grandes perdas", Poesia e prosa, Rio de Janeiro, Aguilar, 1958, volume II, p. 614, apud Irene Jeanete Gilberto Simões, Oficina de artista - a linguagem dos romances de Cornelio Penna, p. 13.
} 
algo estranha e o estranhamento do que acontecia à sua volta possibilitaram um distanciamento que outros não tinham para olhar para o mundo e o tempo, sem contudo, malgrado seu, obter escapar inteiramente de um e de outro. Ao passo que a seta do tempo como que se inverte, sendo figurado a cada romance mais recente um passado mais distante, a sua obra, como veremos, será marcada não tanto pela negação, como pela inversão, pelo quiasmo, pelo avesso. Ao rumar para o passado ao invés de voltar-se para o futuro, ao deslocar-se como que na contramão do movimento mais evidente na literatura do tempo, essa obra, construída em muitos aspectos como que às avessas, pôde mostrar uma realidade que, por assim dizer, se encontrava ela mesma do avesso ${ }^{22}$. Porque o mundo em que se vive no Brasil (e, de modo mais ou menos acentuado, um pouco por toda parte) ao final do século XIX e que avança pelo século XX é um mundo às avessas, um mundo que Euclides retratara tão bem n'Os Sertões, em que o civilizado vira bárbaro e a civilização, barbárie ${ }^{23}$; um mundo cujas contradições Murilo Mendes, para citá-lo uma vez mais, evoca de modo tão sugestivo na exclamação interpolada e que assim sugere não teve como refrear: "Como são recentes essas nossas antiguidades!" A obra corneliana será então marcada pelas tensões entre passado e presente, entre natureza e cultura, entre o campo e a cidade, entre o arcaico e o moderno, entre o subjetivo e o objetivo, entre o sujeito e o mundo, entre o indivíduo e a multidão, isto é, as tensões mesmas que caracterizam o homem dos primeiros decênios do século XX, especialmente daquele que vive nesse país "fronteiriço".

O fato de ser católico ou de ter sido leitor e admirador de São João da Cruz, e mesmo de ter supostamente pretendido trazer questões religiosas e de fé para os romances, não só não restringe o seu sentido mais amplo como é ele mesmo índice da angústia e do sentimento de desamparo do homem na modernidade e que busca de algum modo um apoio na religião ${ }^{24}$. Como afirmou Fausto Cunha a respeito das

\footnotetext{
22 "na obra de Cornélio Penna estabelece-se uma ligação com a realidade brasileira. Mas uma ligação elíptica, nebulosa, e por isso tão instigante quanto incômoda." (Marcelo Tadeu Schincariol, Em busca da alma de Itabira: uma leitura de Cornélio Penna, p. 47.)

${ }^{23}$ Essas questões foram desenvolvidas de modo bastante abrangente e aprofundado no segundo capítulo ("Civilização e barbárie") da tese de doutorado de Josalba Fabiana dos Santos. As posições da autora em muitos momentos coincidem com as minhas, mas me parece que a associação por ela proposta entre a história brasileira e o enredo dos romances cornelianos poderia ter sido menos direta e mais matizada. A falta de algumas mediações de sua interpretação já se evidencia no título mesmo do trabalho, Fronteiras da nação em Cornélio Penna, a que não faltam contudo muitas outras qualidades.

${ }^{24}$ Em Orfeu extático na metrópole, Nicolau Sevcenko mostra como no início do século o sentimento e a fé religiosos tendem a ser deslocados para o esporte (especialmente o futebol), a escultura monumental ou o cinema, dando origem ao que ele denomina "rituais modernos", e como ao mesmo tempo, especialmente com a experiência traumatizante da guerra, ganha força o sentimento propriamente religioso e místico.
} 
próprias personagens cornelianas: "Quando as almas se voltam para Deus, êsse refúgio é uma fuga, o desejo não de salvação moral ou espiritual mas simplesmente de salvação, e eis que é um Deus de imagem, um Deus que é uma posta-restante para endereços desconhecidos." 25 Há uma outra dimensão dessa religiosidade a ser colocada em questão, ainda que com cautela, sobretudo se a consideramos juntamente com o monarquismo do escritor. É preciso indagar se haveria aí apenas uma coincidência com os movimentos populares messiânicos, também eles católicos e monarquistas, e de que Canudos é o melhor exemplo. A história de Maria Santa em Fronteira deve ser suficiente para nos mostrar que essas reflexões não são aleatórias ou abusivas. A princípio, salta aos olhos uma diferença fundamental: o isolamento de um e o caráter aglutinador do outro. Pode-se questionar se não teria sido justamente essa solidão, num tempo em que a palavra massificação praticamente adquire o sentido com que hoje a conhecemos, que permitiu ao escritor figurar uma multidão que ainda não é massa. Tendo mostrado um Brasil tão arraigado a práticas medievais, em que a religião se mistura à magia, a fé religiosa a crenças e superstições populares, tendo figurado os cultos aos santos, as rezas e as procissões tão plásticas e sensacionais, no sentido etimológico da palavra, e ainda os ritos africanos e os hábitos mais comezinhos da casagrande e da senzala, grande parte disso ainda tão presente tanto no seu como em nosso próprio tempo, é no mínimo curioso ver esse escritor rotulado de intimista e introspectivo sem que se frise, ao menos concessivamente, o fato de ter retratado tão bem esses aspectos da realidade brasileira. Não será por que muitos não quiseram e não querem ver essa realidade, especialmente numa figuração em que ela praticamente vem desacompanhada (ou acompanhada de maneira tímida e sem dar-lhe grande destaque) de sua outra face, a sua contraface "moderna", à qual se costuma dar muito mais valor e na qual se projetam o nosso suposto destino inalienável de país do futuro e os anseios de que nosso atraso venha a ser não mais que uma sombra do passado?

Reconhecer o que pode ter fugido à consciência do escritor, isto é, do que pode haver de inescapável nessa e em outras figurações, talvez nos ajude a não incorrer no que considero um erro por parte de alguns críticos ou pelo menos um argumento que me parece o seu tanto desajustado, ao contestarem a crítica feita por Mário de Andrade $^{26}$ e enfatizarem, ao contrário dele, a extrema coerência dos elementos estranhos, imotivados ou inexplicáveis presentes na obra corneliana. Se Cornélio figura um mundo ele mesmo

\footnotetext{
${ }^{25}$ Op. cit., p. 128.

26 "Romances de um antiquário", O empalhador de passarinho, pp. 125-8.
} 
estranho e inexplicável, um mundo onírico e terrificante, irracional e contraditório, teria todo o direito de colocar em seus romances esses elementos misteriosos, que nesse contexto fariam todo o sentido. Mas a impressão que fica diante de uma tal justificativa é a de que, nesse caso, o mais irracional só pôde vir à tona por meio da utilização da consciência mais desperta e da razão mais abstrata. Parece mais próximo da verdade atribuir aqueles elementos não apenas à consciência do criador como também, e sobretudo, à sensibilidade que logra captá-los no mundo e no tempo em que vive. Não se trataria assim apenas de escolher elementos de sonho para ambientar um mundo onírico, mas de que a escolha encontra sua motivação na vida e na história do escritor. Isso não significa absolutamente a afirmação de sua inconsciência. Muito ao contrário, penso mesmo, embora seja talvez difícil prová-lo, que Cornélio Penna não só teria lido a crítica do autor do Macunaíma como, em larga medida, a levou em consideração, passando, a partir de Repouso, a situar o mistério não mais em elementos que parecem imotivados, que "nada justificam, nada condicionam", mas em outro nível, que a análise deverá precisar, mais próximo da realidade que do sonho, por isso muito mais aterrorizante.

Seja pelas tensões apontadas, seja por revelar um Brasil que não se queria reconhecer, seja ainda pela dificuldade em enquadrá-la inteiramente num dos pólos da ficção contemporânea, a crítica, a despeito das qualidades que logo reconheceu na obra corneliana, não deixou de fazer sérias restrições. Como afirma Irene Simões,

se, por um lado, em alguns momentos, (...) priorizou o enfoque temático, situando Cornelio Penna entre os grandes escritores, na moderna ficção universal, por outro lado, mostrou grande desconfiança quanto à composição da obra. Enredo mal estruturado, personagens soltas, repetições de frases e até certos vícios de linguagem foram apontados pelos críticos. ${ }^{27}$

Além disso, enquanto muitos encararam a obra corneliana como moderna, outros sublinharam o que nela viam como passadismo, caracterizando a sua produção como romântica, gótica ou decadentista. É também para tomar partido diante dessas questões que este estudo se debruça sobre essa obra, procurando analisá-la em diversos níveis na busca de uma melhor compreensão desses e de outros problemas, tenham ou não sido apontados pela crítica, indagando em que medida se trata mesmo de defeitos de

${ }^{27}$ Oficina de artista: a linguagem dos romances de Cornelio Penna, p. 4. 
composição ou se, ao contrário, teriam eles um sentido dentro da obra, além de buscar compreender qual seria esse sentido.

Um desses casos é o aparente descompasso ou intervalo entre a expressão em diversos momentos minuciosa e detalhista da realidade (presente desde o primeiro romance, mas que se exacerba n' A menina morta), e a afirmação, geralmente por parte do narrador ou de algum personagem, da impossibilidade de chegar à verdade das coisas. Em outras palavras, a escritura insiste em descrever a realidade exterior, muitas vezes de maneira pormenorizada, ao tempo em que adianta ser essa realidade assim descrita inútil para o conhecimento da verdade, sempre inalcançável e misteriosa, e que não se dará a conhecer ${ }^{28}$. Uma resposta preliminar, a ser ou não confirmada, é que o escritor procura mostrar que, mesmo se virarmos e revirarmos a realidade, buscando descrever seus detalhes mais ínfimos e mais recônditos, haverá sempre algo que nos escapa. Se para ele esse algo encontra resposta apenas na fé e na religião, não é talvez indevido associarmos nós outros essa impossibilidade de conhecimento e essa incerteza a algumas conclusões a que chegaram e chegavam, naquele mesmo tempo, homens acima de qualquer suspeita de deixarem seu pensamento ser influenciado por argumentos religiosos ou metafísicos: Einstein ${ }^{29}$, Planck, Bohr, Heisenberg... Sirva de exemplo um comentário muito posterior de Ilya Prigogine, o físico-químico que propôs a teoria da complexidade e o princípio da incerteza, sobre Niels Bohr e seu princípio da complementaridade:

La vraie leçon du principe de complémentarité, celle qui peut être traduite dans d'autres champs de connaissance, comme Bohr avait toute sa vie essayé de le faire, c'est san doute cette richesse du réel qui déborde chaque langage, chaque structure logique, chaque éclairage conceptuel; chacun peut seulement en exprimer - mais réussit à en exprimer - une partie; ainsi, la musique n'est épuisée par aucune de ses stylisations, le monde des sons est plus riche qu'aucun des langages musicaux, que soit celui de la musique esquimaude, de Bach ou de Schönberg, ne peut l'exprimer; mais chacun constitue un choix, une exploration élective et, en tant que tel, la possibilité d'une plénitude. ${ }^{30}$

\footnotetext{
${ }^{28}$ A problematização dessa questão foi feita pelo prof. Alcides Villaça.

${ }^{29}$ Quanto a Einstein, isso é verdade pelo menos no momento em que propõe a Teoria da Relatividade; depois, virá a afirmação famosa de que "Deus não joga dados", embora mesmo aí haja controvérsias a respeito de sua interpretação.

${ }^{30}$ La nouvelle aliance, pp. 312-4 (grifo em negrito meu).
} 
Ainda que se enfatize aqui que não se trata de fazer qualquer afirmação, mais ou menos categórica, a respeito do conhecimento dessas descobertas e teorias por parte de Cornélio Penna, cabe ao menos notar uma possível afinidade entre as suas sugestões de que a verdade não pode ser dada simplesmente pela observação da realidade com, por exemplo, o que se depreende do princípio da complementaridade de Bohr de que a riqueza do real não pode ser expressa senão parcialmente por uma única linguagem ou por determinada estrutura lógica. É possível também nos valer das palavras do próprio Bohr retiradas de uma conferência de 1938, três anos depois da publicação de Fronteira:

Quão imperiosa não foi também a advertência que recebemos, em nossa época, sobre a relatividade de todos os juízos humanos, através da revisão renovada dos pressupostos subjacentes ao uso inambíguo até mesmo de nossos conceitos mais elementares, como o espaço e o tempo, os quais, ao revelarem a dependência especial em que estão todos os fenômenos físicos do ponto de vista do observador, tanto contribuíram para a unidade e a beleza de toda a nossa visão de mundo? ${ }^{31}$

Reconhecer a relatividade dos juízos humanos é afirmar a impossibilidade de se chegar ao conhecimento de uma verdade única e absoluta, o que de certo modo pode ser entrevisto na permanência do mistério na obra corneliana por mais que a realidade observada seja, com relativa freqüência, descrita de maneira pormenorizada. Se não for despropositado o estabelecimento dessas relações, será possível ver nelas a confirmação de que Cornélio Penna não só não se encontra desvinculado de seu tempo como que esses vínculos acabam por se manifestar de algum modo em sua obra.

Outra explicação para o paradoxo apontado poderia ser dada pela aproximação da atitude do escritor, extensiva ao homem em geral, à de Sísifo, tal como o mito é interpretado por Camus. A tarefa ou o castigo de rolar a pedra montanha acima é inevitável e inescapável, por mais que se saiba que ela sempre tornará ao mesmo lugar para que tudo possa recomeçar. Para além da inutilidade e do sem-sentido da ação, haveria sempre a possibilidade de se refletir sobre ela, especialmente quando se retorna montanha abaixo para o recomeço. O homem pode assim refletir sobre a sua condição absurda mesmo que nunca chegue à descoberta do seu sentido. No caso de Cornélio

\footnotetext{
31 "Filosofia natural e cultura humanas", in: Física atômica e conhecimento humano: ensaios 1932-1957, p. 30 .
} 
Penna, a sua obra poderia ser vista também como a constatação da impossibilidade de se chegar a essa descoberta e, ao mesmo tempo, a inevitabilidade de se continuar a procura, sabendo de antemão que a resposta será sempre o mistério. Haverá certamente outras possibilidades de interpretação, assim como talvez não deixe de ser defensável o ponto de vista de que existiria no romance algum problema de composição.

De tudo o que foi dito, penso que o mais importante é tentar compreender a obra de Cornélio Penna num duplo sentido, universal e particular, nos quais a morte é um tema central. De um ponto de vista mais amplo, pode-se entender a angústia e o mistério como desde os tempos mais remotos ligados à morte, de que não se destaca a impressão do sem-sentido da vida. De outro ponto de vista, mais restrito ou mais histórico, é preciso indagar até onde o sistema econômico e político vigente desde o final da Idade Média e o começo da era Moderna, passando pela Revolução Industrial no século XVIII e pela Segunda Revolução Industrial, no XIX, e implantado em ou transplantado para um país colonial, de direito ou de fato, não seria responsável pelo acirramento dessa angústia e desse sentimento, ao passo que o mistério é aparentemente esclarecido e a morte, por sua vez, negada. Em que medida um dos incômodos mais sensíveis causados pela ficção corneliana não seria o restabelecimento da ligação entre angústia, morte, o sem-sentido da vida e a reposição do mistério no centro da reflexão em um mundo, a despeito de seu atraso, que se crê tão esclarecido?

$* * * * *$

O amigo Lúcio Cardoso registrou em diário, entre outras menções ao autor de Fronteira, uma visita que fez à mulher de Cornélio Penna depois de sua morte:

Visita ontem à noite à viúva de Cornélio Pena. Maria Odília recebe-me num salão cheio de objetos que me são velhos conhecidos - a caixa de música com seus grandes discos de metal, os dois quadros das perdizes, o trabalho da Baronesa do Paraná, a menina morta... todo o ambiente se acha profundamente impregnado de Cornélio Pena, e a viúva me diz: "sua ausência se faz sentir minuto por minuto" - e eu respondo - "é isto, a morte". Porque não há morte para aquêles que não são amados, mas há uma única para os que o foram muito. Relembrando coisas do morto, suas implicâncias, seus entusiasmos - e ela afirma, comovida, que o morto a acompanha sempre, e que naquele momento mesmo ali se acha, ao lado dela, na 
sala. Eu não duvido, tão poderosa é a lembrança do amigo desaparecido e continuamos a conversar num tom mais baixo, como se respeitássemos a presença de alguém que ali estivesse. Durante um momento em que a viúva se afasta a fim de fazer um café, levanto-me, toco com os dedos velhos e preciosos objetos: um álbum de retratos, imagens, o espaldar das cadeiras de jacarandá. Tudo aqui é arrumado como antigamente se arrumava uma casa no Brasil - e sente-se, mas vivo do que nunca, êsse amor do autor pela sua terra, pela sua gente, "por essa alma que buscamos tanto", como se refere êle num trecho sôbre o Itabirismo, e que vislumbrava exatamente Itabira, como um depósito rico e excepcional dêsse angustiado espírito de brasilidade. (Lúcio Cardoso, Diário completo, pp. 259-60)

A fotografia de Cornélio Penna estampada na edição da Artium de Dois romances de Nico Horta, cujo original pode ser visto no acervo do escritor junto à Fundação Casa de Rui Barbosa, impressiona pelo jogo de luz e sombra, como se o fotógrafo, conhecedor e admirador da obra corneliana (que talvez, à época da fotografia, ainda estivesse por ser feita), procurasse transpor para a imagem capturada do escritor os tons do branco e do negro e especialmente os incontáveis entretons do cinza que recobrem praticamente cada uma das páginas de seus romances. De terno e gravata impecáveis, cabelos curtos penteados para trás, meio de perfil, o escritor nos fita de maneira grave e enigmática. Do lado esquerdo vem a dedicatória do livro "à [sua] melhor amiga ITABIRA DO MATO DENTRO”. Na personificação de Itabira e no conjunto formado pela foto e pela dedicatória, podemos entrever a dedicação amorosa e a seriedade com que praticou a arte em que se lançou à tarefa de conhecer Itabira mais a fundo para melhor compreendê-la, e por extensão ao homem e ao Brasil de seu tempo, para aquém ou para além do maniqueísmo que só consegue enxergar ou o branco ou o negro, ou isto ou aquilo, e das constrições desse mesmo tempo, que pretendeu "nivelar em tom cinzento a indistinta massa humana”. 


\subsection{Perspectivas: Sérgio e Tristão}

Os anos 30, em que Cornélio Penna começa a escrever e em que irá publicar seus dois primeiros romances, teriam sido marcados no Brasil por posicionamentos extremados, tendo-se estabelecido assim polaridades que no próprio tempo chegaram a ser vistas como exclusivistas e irreconciliáveis por muitos intelectuais e escritores, para quem parecia quase inescapável a adesão a uma das duas correntes então constituídas. O distanciamento histórico, que com alguma freqüência nos leva a aparar arestas, desfazer saliências e eliminar reentrâncias, parece num primeiro momento - e durante um bom tempo - ter propiciado a impressão de ter sido absoluta essa dicotomia a ponto de tornar muito difícil a especulação não apenas sobre um impensável terceiro não-excluído ${ }^{32}$, como sobre qualquer pensamento que não se enquadrasse inteiramente numa ou noutra posição. Ou se era de esquerda, ou de direita. Comunista ou integralista. Ateu ou católico. Regionalista ou intimista. Ou isto, ou aquilo. Poucos parecem ter conseguido lançar um olhar para esses anos em busca de uma visão menos redutora ou mais compreensiva e matizada dos extremismos de então, o que talvez só tenha ocorrido em maior escala num período mais ou menos recente ${ }^{33}$.

Como quer que seja, matizar não significa negar; buscar uma visão que dê conta da complexidade das posições tomadas pelos homens do tempo não implica o não reconhecimento de que naquele momento muitos se sentiram constrangidos de fato a optar entre posições extremas. Ademais, antes de insistir no que pode haver de relativo no caráter dicotômico do período, caberia talvez enfatizar a relatividade do próprio modo como ficou conhecido esse período pela historiografia e sobretudo pela história da literatura: os "anos 30". Isto é, por óbvio que pareça, é preciso insistir que esses posicionamentos divergentes não têm início em 1930 para desaparecer em 39 ou 40. Sobretudo no que se refere aos artistas e intelectuais, suas origens remontariam pelo menos a 1922. É o que se pode depreender das palavras de Sérgio Buarque de Holanda,

\footnotetext{
32 Immanuel Wallerstein, "O tempo, a duração e o terceiro não-excluído: reflexões sobre Braudel e Prigogine".

33 "Como decorrência do movimento revolucionário e das suas causas, mas também do que acontecia mais ou menos no mesmo sentido na Europa e nos Estados Unidos, houve nos anos 30 uma espécie de convívio íntimo entre a literatura e as ideologias políticas e religiosas. Isto, que antes era excepcional no Brasil, se generalizou naquela altura, a ponto de haver polarização dos intelectuais nos casos mais definidos e explícitos, a saber, os que optavam pelo comunismo ou o fascismo. Mesmo quando não ocorria esta definição extrema, e mesmo quando os intelectuais não tinham consciência clara dos matizes ideológicos, houve penetração difusa das preocupações sociais e religiosas nos textos, como viria a ocorrer de novo nos nossos dias em termos diversos e maior intensidade." (Antonio Candido, "A revolução de 1930 e a cultura", A educação pela noite \& outros ensaios, p. 188, grifos meus.)
} 
que teve participação fundamental no movimento modernista, embora não estivesse presente na "Semana":

O célebre episódio da Academia Brasileira de Letras, de onde Graça Aranha saiu triunfalmente carregado por Alceu Amoroso Lima e Murilo Araújo e ainda escorado por Prudente de Morais, neto, sugere à primeira vista a persistência desse cunho unitário em que parecia fixado o movimento modernista a partir da Semana de Arte Moderna.

Longe, porém, de significar o coroamento de uma perfeita harmonia de intenções e propósitos entre os participantes da revolução, esse episódio representou, a bem dizer, uma última e desesperada tentativa para sustar a inevitável deterioração daquela unanimidade superficial e, em suma, fictícia. ${ }^{34}$

É de se acreditar também que, embora o ápice da radicalização por parte dos dois grupos que podiam ser entrevistos já em 1922 deva ter se dado durante os anos de 1930, essa polarização tenha permanecido ao longo dos anos marcados pela Segunda Grande Guerra e que talvez somente encontre algum apaziguamento a partir de meados da década de 1950, se não for aqui de todo inadequada a utilização de uma palavra que tem paz como radical, e se é de fato verdadeira a imagem de um certo consenso que se fez dessa década sobretudo em sua segunda metade.

Com quase quarenta anos quando escreve e publica Fronteira, Cornélio Penna tinha pouco mais de trinta anos de idade em meados dos anos 20. Era já um artista, tendo a primeira escolha recaído sobre a pintura. Havia cursado a Faculdade de Direito do Largo São Francisco e, ao concluí-la, mudara-se para o Rio e passara a trabalhar em alguns jornais como ilustrador e depois redator. Tinha amizade com diversos intelectuais e escritores, como Murilo Mendes, Marques Rebelo, Alceu Amoroso Lima e Octavio de Faria. Em 1936, um ano depois de publicar o primeiro romance, assumira a direção do Instituto de Artes da Universidade do Distrito Federal, e dois anos depois fora eleito para a vice-presidência da Sociedade Brasileira de Belas-Artes. Assim, é inevitável pensar que ao longo das décadas de 20 e 30 Cornélio Penna tenha tido um momento fundamental de sua formação intelectual, marcada de algum modo pelo "diálogo" com as diferentes correntes do tempo.

\footnotetext{
${ }^{34}$ Sérgio Buarque de Holanda, Tentativas de mitologia, São Paulo, Perspectiva, 1979, p. 273.
} 
Desse modo, talvez seja produtivo para a compreensão de sua obra lançar um olhar sobre esse período, mas em lugar da visão panorâmica, em que se perdem os detalhes, uma visada que procure ao contrário enfatizá-los. A inatingível e insana tarefa de olhar para tudo em todos os seus pormenores - materializada no genial e tão conhecido conto de Borges sobre a confecção do mapa que se quis tão perfeito, para dar conta de cada reentrância, de cada mínimo recorte da geografia da paisagem que se queria mapear, que terminou por recobri-la inteiramente, reproduzindo-a tal e qual, com sua mesma dimensão - será aqui substituída pela escolha de duas figuras fundamentais, e ainda de um ou dois textos igualmente fundamentais de cada uma delas, embora lançando-se mão sempre que necessário de outros textos de apoio - isto é, a opção por um exame um pouco mais demorado de um ou outro fragmento, de uma ou outra faixa estreita de terreno, com uma reentrância aqui, outra ali, mas tudo tão significativo do todo inefável que talvez acabe por dar dele uma idéia relativamente bem acurada, quiçá mais rica que um panorama que tivesse de antemão tal propósito. $O$ fato de que o pensamento de Sérgio Buarque de Holanda e o de Tristão de Athayde não possam absolutamente ser considerados típicos de cada uma daquelas correntes, e muito menos passíveis de nelas serem enquadrados, parece antes uma vantagem que um problema, pois o confronto entre as posições desses dois intelectuais ${ }^{35}$ - confronto notável, que de fato ocorreu e que penso ter sido dos mais fecundos - poderá ao final mostrar-se revelador não apenas das profundas divergências que estavam na ordem do dia como de sua grande complexidade, irredutível a toda e qualquer leitura maniqueísta.

Em 1925, no terceiro número da revista Estética, dirigida por Prudente de Morais Neto e Sérgio Buarque de Holanda, este fez publicar um artigo intitulado "Perspectivas". É quase inacreditável que fora um jovem de apenas 23 anos quem escrevera um ensaio como aquele. Não tive acesso à revista, mas a transcrição do texto ocupa não mais que cinco páginas impressas no primeiro volume do livro fundamental organizado por Antonio Arnoni Prado, que traz os estudos de crítica literária publicados por Sérgio Buarque de 1920 a $1959^{36}$.

Proclamando, entre outras coisas, que a mediocridade ou a grandeza do mundo visível só dependem da qualidade da representação que dele se faz, e que assim a "arte poética", mais do que nunca, havia de ser "uma declaração dos direitos do Sonho", o

\footnotetext{
35 A generosa sugestão desse confronto partiu do prof. Elias Thomé Saliba durante o exame de qualificação.

${ }^{36}$ O espírito e a letra: estudos de crítica literária I, p. 214-8.
} 
jovem Sérgio Buarque investe contra o pensamento e a palavra que lhe parecem confortavelmente instalados, que se costuma chamar expressão mas que são menos que reflexo, contra "o sacrifício de tudo quanto escapa à lógica da continuidade", contra "a engenhosa caligrafia que os homens inventaram para substituir o desenho rígido e anguloso das cousas", contra - enfim - tudo o que toma partido do que é morto e acaba por negar a vida. Diante dos grandes sistemas que uniformizam, que nivelam, que subordinam o singular ao universal, que consideram inútil "o que há em cada um de individual" para a formação do conceito, Sérgio Buarque se alinha ao lado de "certos homens" para quem "o essencial continua sendo o que há de particular, o que há de milagroso, o elemento irredutível em cada cousa".

Nos primórdios da arte, nas paredes das cavernas, já se encontrariam os rudimentos desse "afã de reduzir o informe à forma, o livre ao necessário, o acidental à regra”, pois, muito mais que por um impulso de libertação, aqueles homens teriam sido levados pelo “desejo invencível de negar a vida em todas as suas manifestações”. Esse ponto de vista, segundo o próprio Sérgio, propõe-lhe diversas perspectivas que não lhe cabe resumir nesse artigo, e o parágrafo final assim introduzido parece-me algo obscuro, inteiramente de acordo com o paradoxo que poderia ser considerado o mote fundamental de todo o texto: "Só à noite enxergamos claro." Se queremos conhecer e expressar a vida e não a morte, podemos encontrá-la tão-somente nas profundezas, nas "regiões inexploradas", nas zonas obscuras e sombrias, sobre as quais ainda não se projetou a luz do pensamento formal e abstrato, que retira a vida do que se propõe a conhecer na medida mesma em que o ilumina. Daí as imagens utilizadas de dissecação, atmosfera irrespirável, linguagem dos cemitérios.

"Só à noite enxergamos claro." Somente nas "expedições armadas" pelos domínios do sonho, do instável, do provisório, do contingente, da renúncia a essa linguagem morta, só assim é que o homem poderá buscar "atrair a tempestade, invocar o demônio ou realizar o mistério dentro do cotidiano". A morte, contudo, continua a ser sempre uma poderosa atração, pois nem "todos sentiram que não é necessário renunciar à vida para descobrir o 'irreal' e que ao contrário o que parece mais real e até mesmo que se apresenta mais dócil à verificação comporta uma parte de mistério imprevisível e traz concessões escandalosas ao irracional".

Se pensarmos então nas menções feitas à representação e à realidade, o pensamento que se expressa nesse ensaio tão denso é o de que, se esse mistério e esse irracional fazem parte da vida, a sua expressão só será viva se não descartá-los, mas ao 
contrário incorporá-los em seu tecido, em sua textura, em sua forma. Ao mesmo tempo, são essas expressões ou representações que fazem a grandeza do "mundo visível", da realidade, da vida. Nesse sentido, embora não se trate de um texto artístico, "Perspectivas" parece trazer em sua estrutura algo da homologia entre forma e conteúdo própria das criações da arte e da poesia. Em vez de um pensamento que procede por indução ou dedução, por meio de definições precisas e da paulatina refutação de idéias contrárias, Sérgio Buarque parece optar quase sempre por imagens e aforismos, procedendo por assim dizer mais por justaposição e acréscimo que pelo encadeamento e concatenação de idéias, mais por meio da parataxe do que da hipotaxe.

Em 04 de outubro de 1925, poucos meses portanto após o lançamento do terceiro número de Estética, Tristão de Athayde dá notícia dessa publicação e submete "Perspectivas" de Sérgio Buarque de Holanda a uma cerrada crítica ${ }^{37}$. O artigo, embora "um pouco obscuramente escrito", teria sido "profundamente pensado", e estaria "errado também profundamente". Segundo Tristão tratava-se - sem mencioná-lo - de uma apologia do "supra-realismo", e não só não trazia nada de novo em relação ao que fora proposto por um grupo de ex-dadaístas europeus como tinha o agravante de fazê-lo em nome da vida, enquanto estes "estavam muito conscientes que aquilo era a 'morte" ". À visão expressa no artigo de que "toda conformação do informe é uma morte, pois que só o caos tem vida", Tristão responde:

A vida é justamente o que se organiza, o que se coordena, o que se conforma. $\mathrm{O}$ caos não é vida, é simples agitação. A tendência à razão é a lei de insuflação de vida. O silêncio é o predecessor da morte. E o sono, mais ainda. O sonho pouco tem de autônomo. O sonho é um resíduo ou uma aspiração à vida. Ele é feito de pedaços descozidos de vida. O sonho pouco nos revela do que não esteja na vigília. E o estado do sonho é sempre um estado de semi-inércia. O sonho lembra a vida, é uma sombra vaga de vida, não existiria sem a vida. O sonho é a sombra da vida.

No caso dos europeus, profundamente marcados pela experiência da guerra, esse tomar partido do que, segundo Tristão, representa a "morte" seria plenamente compreensível ainda que como um "horrível [...] grito sincero de desespero". No Brasil, nada mais seria que o resultado do hábito que data de um século de imitar, repetir e “refletir docilmente movimentos alheios". E, ao final de seu artigo, depois de associar o

${ }^{37}$ Alceu Amoroso Lima, “A salvação pelo angélico”, Estudos literários, p. 988-94. 
"supra-realismo" ao desvario, aos delírios do subjetivismo e da anarquia, como aqueles trazidos pela poesia do Sr. Oswald de Andrade, Tristão de Athayde contrapõe ao "Só à noite enxergamos claro" de Sérgio Buarque e ao artigo como um todo o seu "ponto de vista": "Nunca tivemos, como hoje, tanta necessidade de consciência, de lucidez, de disciplina, de predomínio da claridade sobre o obscuro.” E conclui: "para nós, que ainda não conseguimos escalar o divino, só uma salvação nos resta: o angélico.”

Passados exatos doze meses, Sérgio publica na Revista do Brasil (15 de outubro de 1926) um outro artigo, intitulado "O lado oposto e outros lados",38, em que - sem meias-palavras e com certa virulência - as divergências apenas sugeridas até então são definitivamente explicitadas, dando inclusive "nome aos bois". Começa pelo "lado oposto", o dos "acadêmicos modernizantes", dos que "aparentaram por certo tempo responder às instâncias da nossa geração", mas que "falharam irremediavelmente", dos que "fazem todo o possível para sentirem um pouco a inquietação da gente da vanguarda" e que na verdade "idealizam [...] a criação de uma elite de homens, inteligentes e sábios, embora sem grande contato com a terra e com o povo [...], gente bem-intencionada e que esteja de qualquer modo à altura de nos impor uma hierarquia, uma ordem, uma experiência que estrangulem de vez esse nosso maldito estouvamento de povo moço e sem juízo": Graça Aranha, Ronald de Carvalho, Renato Almeida, Guilherme de Almeida e Tristão de Athayde. Esses "hoje [...] não significam mais nada para nós". Do outro lado, os que contam, os que "representam o ponto necessário de resistência contra as ideologias do construtivismo": Oswald de Andrade, Prudente de Morais Neto, Couto de Barros, Antônio de Alcântara Machado, Manuel Bandeira, Ribeiro Couto e Mário de Andrade. A este, porém, cujas realizações lhe parecem das mais admiráveis, faz um alerta: o ponto fraco de sua obra, o que nela há de "mau" (ainda que sempre admirável) encontra-se quase invariavelmente naquilo que seu pensamento coincide com o de Tristão de Athayde. Este é visto como o escritor mais representativo daquela tendência e seu pensamento mais considerável que o dos demais, por isso mesmo merecedor de uma recusa ainda mais decidida. A alusão à "panacéia abominável de construção" certamente se refere às suas idéias e é muito provavelmente nele que pensa Sérgio Buarque ao tecer estas considerações incisivas e irônicas:

Porque para eles, por enquanto, nós nos comprazemos na desordem. Desordem do quê? É indispensável essa pergunta, porquanto a ordem perturbada entre nós não é

\footnotetext{
${ }^{38}$ O espírito e a letra: estudos de crítica literária I, p. 224-8.
} 
decerto, não pode ser a nossa ordem; há de ser uma coisa fictícia e estranha a nós, uma lei morta, que importamos, senão do outro mundo, pelo menos do Velho Mundo. É preciso mandar buscar esses espartilhos pra que a gente aprenda a se fazer apresentável e bonito à vista dos outros. O erro deles está nisso de quererem escamotear a nossa liberdade que é, por enquanto pelo menos, o que temos de mais considerável, em proveito de uma detestável abstração inoportuna e vazia de sentido. Não me lembro mais como é a frase que li num ensaio do francês Jean Richard Bloch e em que ele lamenta não ter nascido num país novo, sem tradições, onde todas as experiências tivessem uma razão de ser e onde uma expressão artística livre de compromissos não fosse ousadia inqualificável. Aqui há muita gente que parece lamentar não sermos precisamente um país velho e cheio de heranças onde se pudesse criar uma arte sujeita a regras e a ideais prefixados.

A despeito da solidariedade demonstrada por gente como Manuel Bandeira e Prudente de Morais Neto, que inclusive escreveu um outro artigo com o mesmo título, "O lado oposto e outros lados", publicado no jornal A Manhã, a acolhida ao artigo de Sérgio Buarque não deve ter sido nada boa, mesmo entre um ou outro que não fora por ele lançado em meio aos do "lado oposto", como Mário de Andrade. A este parece que não teria agradado o tom ferino e mordente utilizado por Sérgio, apesar de reconhecer que o artigo fora "admiravelmente bem pensado e bem escrito, de absoluta nobreza intelectual e moral". Sérgio e Prudente, porém, quando escreviam contra davam "pras frases um ar de ataque que fere" ${ }^{39}$. É óbvio, contudo, que as reações mais virulentas vieram daquele lado: "foi de Guilherme de Almeida que partiu a represália mais veemente, com doestos e injúrias, que se estendeu até as chamadas seções livres dos jornais. As desavenças até então limitadas a gozações e piadas, no Modernismo, regrediam às costumeiras e mofinas da imprensa marrom." 40 Teria sido esse clima de intolerância o que fez com que Sérgio Buarque de Holanda, desiludido, partisse para Cachoeiro do Itapemirim, ao aceitar um convite para dirigir nessa cidade um jornal chamado $O$ Progresso, antes do que teria distribuído entre os amigos boa parte de sua biblioteca.

\footnotetext{
39 Todo esse contexto vem descrito de modo relativamente minucioso em "Verdes anos de Sérgio Buarque de Holanda. Ensaio sobre sua formação intelectual até Raízes do Brasil", de Francisco de Assis Barbosa. Desse texto fundamental é que muitas das informações aqui mencionadas foram retiradas e inclusive algumas citações, como as relativas à reação de Mário de Andrade.

${ }^{40}$ Idem, ibid., p. 41.
} 
A resposta mais importante, ou pelo menos a que mais nos interessa, é a de Tristão de Athayde. Republicada em seus Estudos - $1^{a}$ série, em 1927, é bem possível que "Construtivismo e destrutivismo" 41 tenha saído logo depois da publicação do artigo de Sérgio Buarque, na seção literária, conhecida como rodapé, que manteve quase sem interrupção durante vinte e cinco anos em $O$ Jornal. Começa, ao contrário talvez do que se poderia esperar, pelo elogio da erudição ("tem lido este mundo e o outro") e sobretudo da "sinceridade" de seu oponente, afirmando ainda que ele "é dos que contam". Depois, diz estar convencido de que, no artigo publicado na Revista do Brasil, Sérgio fez "uma caricatura de certas idéias minhas sobre o modernismo brasileiro". E, devolvendo a ironia, prossegue:

O Sr. Buarque de Hollanda concede-me a honra (imerecida, etc.) de ser o principal culpado de uma coisa chamada - "construtivismo". O construtivismo, a seu ver, é um mal arquitetônico, um mal estático, um mal disciplinador, um mal intelectualista, que eu, e meus companheiros de culpa, importamos diretamente da Action Française, de Maritain, de Benda, de Eliot, etc. E a grande culpa desse mal coordenador é impedir os novos de vagarem no subconsciente, de catarem pulgas no morro da Favela, com ou sem Marinetti, de se deliciarem no Circo Spinelli com "A filha do bandido ou A vingança do Morto", de falarem patuá, de serem livres enfim. Este o libelo acusatório. Que não é a primeira vez nem será a última, espero, que me seja lançado.

A partir daí, Tristão de Athayde, depois de afirmar a contradição do interlocutor em defender o ilimitado ao tempo em que busca estabelecer limites claros que o separem daqueles "do lado oposto", passa a defender a idéia de que a arte é sempre uma libertação, e que portanto seria "muito simplória essa idéia de liberdade como bandeira única de reivindicação estética". A liberdade seria um elemento inalienável do trabalho artístico, "sem o que nem mesmo se pode cogitar de arte". Mas ao lado dessa liberdade haveria invariavelmente uma determinada "servidão": o artista teria sempre uma meta, um fim a atingir, e para atingi-lo "tem de servir a esse fim, de se adaptar a esse fim, de encaminhar a sua emoção interior a esse fim”. E, finalmente, depois de reconhecer que nem ele mudará o modo de Sérgio pensar nem vice-versa, afirma que a acusação deste de que são todos importados os modelos de que se vale para a defesa de suas idéias

\footnotetext{
${ }^{41}$ Estudos - $1^{a}$ série, p. 191-200.
} 
sobre o "construtivismo" pode ser voltada contra ele mesmo, não sendo difícil citar "os nomes, os grupos, as idéias [...] para mostrar os modelos diretos, imediatos, do seu primitivismo, da sua liberdade, do seu subconsciente".

O diálogo não iria, porém, terminar aí com debandada de Sérgio para o interior. Pouco depois estava de volta, a tempo de acompanhar o lançamento de Estudos, de Tristão de Athayde, que reunia artigos publicados na imprensa entre 1926 e 1927. Em 29 de agosto de 1928, Sérgio publica no Jornal do Brasil um artigo intitulado simplesmente "Tristão de Athayde", que - podendo ser visto como uma resenha do livro recém-publicado - é na verdade uma sondagem das mais profundas de toda a obra e do pensamento de Alceu Amoroso Lima. Nesse artigo ele põe às claras as hesitações e contradições que perpassam essa obra e esse pensamento:

Ele compreendeu bem claramente que a solução final de todas essas antinomias só nascerá de nossa fidelidade a um plano superior e transcendental. Em outras palavras: que só poderá ser uma solução religiosa. A todo instante encontramos nas páginas de seu livro desses acenos indecisos a uma justificação transcendente, dessas exigências de absoluto, esses apelos, enfim, ao "elemento espiritual", à "mística criadora", que virá fundir e elevar [?] os aspectos contraditórios de nossa existência. Esse recurso a uma justificação espiritual não é inédito, dele compartilha toda uma classe de pensadores novos com os quais o autor destes Estudos apresenta importantes afinidades. É um processo que não deixa de evocar a fórmula que presidiu à elaboração das grandes Summas medievais. Apenas com esta diferença, que nelas o que existia era uma fé em busca de suas justificações, de suas razões - fides quaerens intellectus - quando, no caso presente, será antes uma inteligência que quer se apoiar numa base emocional. $\mathrm{O}$ Sr. Tristão de Athayde limita-se a inverter o problema que se ofereceu ao Doutor Angélico.

Assim, o que Sérgio percebe de maneira tão aguda é que o pensamento de Tristão de Athayde, antes que este fizesse qualquer declaração nesse sentido, dirigia-se inapelavelmente para o catolicismo. E os conflitos e contradições internas que nele transpareciam deviam-se sobretudo à hesitação em assumir de modo definitivo que encontrara a solução religiosa para a "pacificação impossível do espiritual com o temporal": "Nenhuma outra doutrina conviria tão plenamente a um homem que aspira a organizar a sua desordem neste mundo sem recusar subvenções do outro mundo. É que, 
mesmo independente delas, se não vierem, desejaria 'restabelecer um equilíbrio da vida, disciplinar os demonismos da liberdade" ".

O que poderia talvez ser expresso por meio do aforismo "acender uma vela a Deus e outra, ao diabo" seria, segundo Sérgio Buarque, um

fenômeno bem característico deste tempo, um tradicionalismo que intimamente descrê das tradições, um dogmatismo que, no fundo, é um ceticismo e, por mais absurdo que possa parecer, um racionalismo que quer ser ao mesmo tempo um misticismo. Ele não compreende, ou não quer compreender, ou finge não compreender que existe uma cesura, uma disjunção fundamental entre o Espírito e a Terra ou, para usar suas próprias expressões, entre o "plano das verticalidades" e o "plano das horizontalidades". Toda a conciliação que se propuser entre esses dois planos não será outra cousa que um hibridismo insólito, uma aglutinação superficial, jamais uma combinação íntima e suscetível de permanência. Não se pode mais hoje, como no tempo de Santo Agostinho, ser, ao mesmo tempo, e simultaneamente um cidadão do céu e da terra. E o pensamento que realmente quiser importar para a nossa época há de se afirmar sem nenhum receio pelos seus reflexos sociais, por mais detestáveis que estes pareçam.

O que Sérgio enfatizava era a necessidade de se fazer uma escolha entre a terra e o céu. Quem quisesse verdadeiramente atuar naquela teria necessariamente de abrir mão deste. E o final do artigo, em que não se disfarça uma profunda decepção, aponta de maneira inequívoca para o fato de que Sérgio Buarque chegou um dia a acreditar que a obra e a personalidade de Tristão de Athayde, a quem confessa admirar, pudessem ser importantes e imprescindíveis para a sua geração e para aquele momento, isto é, que fossem fundamentais para o seu aqui e agora. ${ }^{42}$

Ocorre que Tristão de Athayde, sem se decidir a abandoná-los, tomará de vez não o partido do temporal e do terreno, mas irá ao contrário assumir definitiva e publicamente o catolicismo até então latente. Em 1929, em “Adeus à disponibilidade (Carta a Sérgio Buarque de Holanda)" "43, Alceu Amoroso Lima reconhece que o que seu interlocutor apontara a respeito das hesitações e contradições e mesmo da "vaidade

42 "Esperei poder falar das excelências deste livro do Sr. Tristão de Athayde: limitei-me a dizer, desajeitadamente, das suas fraquezas. Sinto agora, contudo, que não poderia considerar de modo diverso uma obra e uma personalidade que eu admiro e que desejaria fossem realmente importantes, fossem imprescindíveis para nossa geração e para nosso momento."

${ }^{43}$ Adeus à disponibilidade e outros adeuses, p. 15-20. Antonio Carlos Villaça informa que teria sido publicada em A Ordem, em dezembro de 1928. (O pensamento católico no Brasil, p. 179.) 
de querer resolver sozinho o problema da vida e de querer influir pessoalmente para que outros o resolvessem da mesma forma", tudo isso era "perfeitamente justo". E a partir daí passa a tecer considerações sobre a opção pelo catolicismo que afinal não tinha mais como não tomar e declarar de público. Nelas, percebe-se o tempo todo - ao lado das críticas à opção (ou à inopção) de Sérgio pela "disponibilidade gideana”, que ele, Alceu, acabava de recusar, e também do reconhecimento da dificuldade que ele devia ter tido ao tomá-la e a que ainda teria para mantê-la - o profundo respeito intelectual pelo adversário de idéias e amigo:

V. escolheu o caminho da inopção. V. extralimitou todos os seus limites. E é possível que para fazê-lo tenha tido de vencer em si próprio muralhas tão intransponíveis, desertos tão áridos e tão martirizadores, como os daqueles que seguiam o caminho contrário. E a vitória tem de ser incessante, pois a cada minuto recomeça em nós a virginalidade da vida. Para aqueles, como V., que vieram do alto das torres para as planícies, haverá seguramente um dilaceramento tão fundo na alma, como para aqueles que sentiram em si, dia a dia, a ruptura das limitações naturais.

Mas os caminhos da vida não nos separam. E eu confio profundamente no sentido, que V. tem, do que há de trágico na Verdade, ou como V. escreveu no seu ensaio sobre Thomas Hardy: "Somente o caminho do Mal e a experiência da Dor podem nos transferir para um mundo mais elevado. A dor é um enriquecimento, uma simples escala, um elemento indispensável para a nossa ascensão. É esse o sentido fundamental da tragédia cristã".

Quem escreveu essas linhas é que compreendeu até onde vai a sombra da Cruz. E é por lá que nos encontraremos.

Segundo Francisco de Assis Barbosa, Sérgio Buarque se manteria sempre fiel à inopção referida por Alceu: "Sérgio era ateu e assim se conservará até o fim."44

Da parte de Tristão de Athayde, haveria ainda uma espécie de último "capítulo", que apareceria na imprensa e seria pouco tempo depois republicado em Estudos $-2^{a}$ série, de 1928. Certamente não por acaso esse artigo era intitulado "Perspectivas"; não é possível pensar que Alceu Amoroso Lima não tenha escolhido um tal título em referência e como contraponto ao artigo de Sérgio Buarque de Holanda de menos de três anos antes. E pelo que se pode depreender dessa leitura, Tristão de Athayde converteu-

44 "Verdes anos de Sérgio Buarque de Holanda", p. 43. 
se ao catolicismo, assumindo assim de vez o que antes podia ser apenas intuído por uma sensibilidade e inteligência como a de Sérgio Buarque, mas não abandonou absolutamente o desejo de conciliação entre opostos e muito menos a admiração pelos "ideais de estabilidade" e a busca de "limites e barreiras" a que este se referia. Investe contra a "disponibilidade gideana" uma vez mais, ou o "sibaritismo intelectual", ao passo em que afirma o dever "de procurar os limites da dissolução, a rocha firme que se oculta no fundo do lodo". Lamenta e enfatiza a crise que se abate sobre a humanidade: "Onde víamos a unidade intangível surge a diversidade crescente. Onde nos parecia inabalável uma ordem normal, vemos a normalidade da desordem e da agitação. [...] E o repouso interior parece impossível entre tanta efervescência."

Onde podemos encontrar um melhor vislumbre do seu modo de pensamento é na estrutura mesma do ensaio. E para isso não carece nenhum trabalho. O próprio autor não resistiu a acrescentar ao final de seu texto um "diagrama de 'Totalismo" ":

Estética, da liberdade e da criação.

Psicologia, da instabilidade e da dissociação.

Sociologia, da preservação e da perfectibilidade.

Ciência, da experimentação e da racionalidade.

Filosofia, dos valores permanentes.

Religião, da Eternidade e do Espírito.

É mais do que provável que Alceu Amoroso Lima tenha partido desse esquema para a redação do artigo, semelhante a um outro esquema - apenas um pouco mais extenso - que pode ser visto na edição da Aguilar de seus Estudos literários, tanto em seu original manuscrito como numa disposição em caracteres gráficos - preparado para uma conferência ministrada por ele sobre o Espírito Universitário. Em ambos, o pensamento opera por divisões e extensões que vão se estruturando por compartimentos que simultaneamente se opõem e se relacionam entre si. E é dele mesmo a afirmação mais esclarecedora sobre esse procedimento: "porque não creio no super-homem, porque vejo a cada momento os limites do ser humano como o ilimitado do nosso espírito, é que procuro traçar, de vem em quando, como que um reticulado em que consiga, se não conter, ao menos indicar os pontos capitais da nossa complexidade". Assim, por exemplo, parte do que seriam as três atitudes fundamentais do homem: em face da natureza, em face dos semelhantes e em face de si mesmo. Em face da natureza, 
é levado a compreender: surge daí a ciência. Mas a observação não lhe basta, necessita igualmente interpretar: surge a filosofia. Mas resta o inexplicável: e assim surge a religião. Depois, o homem em face dos semelhantes: surgem o direito, a economia e a política. E assim por diante, até chegar à totalidade. Contudo, para avaliar em toda a extensão esse pensamento tão bem compreendido por Sérgio Buarque, é necessária a transcrição do parágrafo final: "Diagrama árido, seco, geométrico, pedante, como deve ser, de propósito. Todo um castelo de cartas sobre o coração humano. Sombras sobre sombra."

A indecisão não poderia ser melhor evidenciada. Depois de tecer uma complicada estrutura para dar conta de tudo que se refere ao homem, o que sugere um controle e um domínio por assim dizer matemáticos do pensamento analítico, uma lógica e um rigor absolutos no uso da razão, a afirmação de que o resultado a que chegou não passa de "sombras sobre sombra".

Em todo caso, fundamental aqui é ressaltar a importância dessa disputa que teve lugar num contexto em que os homens, a despeito da presença de maiores ou menores contradições no próprio pensamento, pareciam sentir como inescapável a explicitação tanto de suas crenças e convicções como daquilo que recusavam, o seu posicionamento ao lado de um determinado grupo e o concomitante afastamento dos que pensavam de modo diferente. E nesse sentido releva o fato de o embate entre Tristão de Athayde e Sérgio Buarque de Holanda ter sido um confronto de idéias de uma força e profundidade como dificilmente teremos tido oportunidade de acompanhar num país em que, além do acanhamento intelectual a que parecemos fadados, essas disputas aparentam ser quase sempre mesquinhas e movidas por interesses escusos e só raramente - hoje mais do que nunca - envolvendo discussão efetiva de idéias. É por tudo isso que esse embate, esse confronto particular é um momento privilegiado para avaliarmos as tensões fundamentais que surgiram na sociedade brasileira daquele período e que sem dúvida se estenderam ainda por um longo tempo, se é que algumas delas não tenham sobrevivido até os nossos dias.

Os dois "contendores", relativamente jovens, vieram depois mais do que confirmar a posição de destaque que então apenas começavam a assumir no cenário intelectual brasileiro. Alceu Amoroso Lima, de quem - ainda jovem - se podia dizer o mesmo que disse de Sérgio Buarque sobre ter lido este mundo e o outro, manteve uma produção intelectual impressionantemente prolífica, embora, segundo João Luiz Lafetá, depois da conversão declarada a sua influência sobre a intelectualidade brasileira, até 
então muito significativa, tenha decaído consideravelmente, na mesma medida em que ela crescia de maneira acentuada entre os católicos ${ }^{45}$. Presidente do famoso Centro Dom Vital e da Ação Católica por muitos anos e fundador e um dos principais responsáveis pela Editora Agir, tornou-se uma das mais importantes figuras do catolicismo brasileiro e uma espécie de herdeiro do pensamento de Jackson de Figueiredo ${ }^{46}$. Quanto a Sérgio Buarque de Holanda, foi aos poucos trocando a crítica - embora a tenha exercido regularmente até pelo menos 1959 - pela historiografia, vindo a se tornar um de nossos maiores historiadores, autor de clássicos como Raízes do Brasil, Caminhos e fronteiras, Monções e Visão do paraíso, além de ter se dedicado a uma carreira acadêmica exemplar na Faculdade de Filosofia, Letras e Ciências Humanas da Universidade de São Paulo, formando mais de uma geração de historiadores que foram por ele diretamente orientados ou, indiretamente, por meio de seus orientandos.

Do ponto de vista político, embora tivesse pelo menos flertado com o Integralismo de Plínio Salgado, Alceu Amoroso Lima parece ter vivido bastante para ao menos contrastar esse passado com a mais firme adesão aos princípios democráticos. Numa entrevista concedida quase aos 90 anos de idade, marcada por alguns momentos bastante tocantes, em que se refere à morte relativamente recente da mulher, companheira de 65 anos, ele mesmo tece comentários a respeito dessas questões:

Ao contrário da lenda, nunca fui integralista. Tive simpatias por esse movimento, graças principalmente a seu conteúdo antiburguês, mas jamais me agradou a idéia de ter um chefe. É exato dizer-se que passei da direita para a esquerda, mas não, como supõem alguns, do reacionarismo para o comunismo. Defino-me como um socialista pluralista, sinto fascínio pelo socialismo com liberdade. ${ }^{47}$

João Luiz Lafetá confirma ambas as coisas, a simpatia pelo Integralismo e pelo fascismo - "Tristão deixou-se em parte levar pelo fascismo de Mussolini (bastante) e de Hitler (menos). Suas demonstrações de simpatia pelo Integralismo, embora não pareça em nenhum momento entusiasmado ou disposto a aderir francamente, são freqüentes e

45 1930: a crítica e o Modernismo, p. 77 e sgs.

${ }^{46}$ Idem, ibidem e Renard Perez, "Tristão de Athayde", Escritores brasileiros contemporâneos, p. 343-56. Mário de Andrade dirá da conversão: "Perdemos um excelente crítico literário, apesar dos defeitos, excelente; ganhamos um pensador católico. Que estamos de parabem [sic] é a minha opinião." ("Tristão de Athayde", Aspectos da literatura brasileira, p. 10.)

47 "Eu votei na mudança: às vésperas dos 90 anos, o grande pensador católico analisa o Brasil que surgiu das urnas e medita sobre a velhice, o amor e a morte", por Augusto Nunes, Veja, 08/12/82. 
significativas." - e, diante da eclosão da guerra, a defesa da liberdade e da democracia: "Mas é preciso fazer-lhe justiça: com a guerra e com a revelação dos horrores cometidos pelos nacionais-socialistas, que a seu ver teriam 'mergulhado o mundo num crepúsculo de sangue e miséria sem nome', a partir de 1939 começa a pender para o lado da Liberdade e a abandonar o partido da Autoridade." 48

Quanto a Sérgio Buarque, Antonio Candido já mostrou como, em Raízes do Brasil, lançado em 1936, especialmente no último capítulo, "Nossa revolução", ele já manifesta um "radicalismo democrático raro [...] fora dos pequenos agrupamentos de esquerda", uma defesa corajosa da tomada pelo povo de seu destino em suas próprias mãos, por oposição à tutela das elites e das oligarquias, fazendo suas as palavras de Herbert Smith sobre a "revolução vertical". É aí que também expressa sua preocupação com as tendências conservadoras que ameaçavam se erguer contra os acontecimentos que se encaminhavam no sentido daquela transformação. A posterior adesão ao Partido dos Trabalhadores, de que foi um dos fundadores em 1980, parece ter sido nada mais que um desdobramento de uma visão política absolutamente coerente da juventude até a maturidade. A participação na fundação da Associação Brasileira dos Escritores, em 1942, a inscrição como um dos fundadores da Esquerda Democrática em 1945 e a decisão de pedir a aposentadoria do cargo de professor da Universidade de São Paulo em solidariedade aos colegas afastados de sua função, por meio de aposentadoria compulsória, pelo AI-5 foram algumas de muitas etapas num percurso que nunca se afastou da defesa intransigente da liberdade e da democracia ${ }^{49}$.

De seu trabalho como historiador, opto uma vez mais por uma transcrição, agora das palavras de Maria Odila da Silva Dias, uma das mais importantes historiadoras por ele formadas, por meio das quais pode-se entrever o modo como aquelas idéias defendidas desde a escrita de "Perspectivas", aos vinte e três anos de idade, mesmo que

\footnotetext{
${ }^{48}$ Idem, ibidem, p. 110 e 113. Caminhos muito semelhantes trilhados por ex-integralistas parecem ter sido relativamente comuns, como se pode constatar em depoimento de Antonio Candido: "Caberia aqui, aliás, uma reflexão desapaixonada sobre esses adversários da mesma geração, em geral integralistas. Apesar da estima pessoal que tínhamos eventualmente por alguns deles, nós os reputávamos representantes de uma filosofia política e social perniciosa, sendo, como era, manifestação local do fascismo. No entanto, a distância mostra que o integralismo foi, para vários jovens, mais do que um fanatismo e uma forma de resistência reacionária. Foi um tipo de interesse fecundo pelas coisas brasileiras, uma tentativa de substituir a platibanda liberalóide por algo mais vivo. Isso explica o maior número de integralistas que foram transitando para posições de esquerda - da cisão de Jeová Mota às abjurações do decênio de 1940, durante a guerra e depois dela. Todos sabem que nas tentativas de reforma social cerceadas pelo golpe de 1964 participaram antigos integralistas identificados às melhores posições do momento." ("O significado de Raízes do Brasil", Raízes do Brasil, p. XXI-XXII)

${ }^{49}$ Idem, ibidem, p. XIX-XXX e "A visão política de Sérgio Buarque de Holanda", Sérgio Buarque de Holanda e o Brasil, p. 81-8.
} 
amadurecidas e modificadas de acordo com a nova tarefa a que se propunha, permaneceram e foram fundamentais para a construção de uma obra tão original como instigante:

Nessa linha de pensamento, o estilo de Sérgio Buarque de Holanda aparece como seu principal instrumento interpretativo: busca o concreto, como concreta e imanente é sua conceituação das forças históricas. Sem dogmatismos, avesso a teorias, pretende lidar com a especificidade histórica e com o tema da mudança no tempo através da cuidadosa construção de um estilo de escrever. A linguagem e as palavras eram as pontes entre a sua consciência e a dos testemunhos da época. As tendências mais avançadas do pensamento contemporâneo demonstram que a ausência de teorias não implica falta de elaboração intelectual. Suas posturas filosóficas relativistas exerceram papel intenso na idealização de suas obras. É o que demonstra cabalmente a sua preocupação modernista, iconoclasta com o poder cognitivo das palavras, que foi o aspecto mais inovador de sua obra: tanto a preocupação com a historicidade cambiante das palavras - que tem a ver com o exercício da empatia histórica, i.e., a palavra como ponte entre a consciência do historiador e a dos seus testemunhos - como um outro nível, o papel do linguajar do historiador, o seu instrumento de interpretação do passado, este que o historiador constrói para representar o passado. A erudição do historiador, que se transformava num instrumento de conhecimento e de interpretação, foi sua contribuição mais sofisticada para elaboração do estilo do historiador, capaz de reconstruir, devassar, representar com minúcias aspectos do modo de ser das sociedades de épocas passadas.

Para o historismo, que atraiu Sérgio Buarque de Holanda desde a década de 20, a relação entre as palavras e a realidade era uma questão de interpretação e não de erudição filosófica. A conotação palavra-realidade, palavras-nuanças, buscava o seu movimento no tempo, procurando apreender a descontinuidade inerente ao processo histórico, que se estrutura e se desestrutura a cada instante.

Era o que o levava a evocar às vezes as Investigações Filosóficas de Ludwig Wittgenstein, obra em que o filósofo desfaz as bases do seu Tractatus anterior, apelando para o descritivo e o configurativo, em lugar de idéias preconcebidas ou de modelos hipotéticos. No estudo do nexo entre as palavras, não existem leis nem regras fixas independentes de sua aplicação a casos particulares, que de fato definem o seu sentido. É o consenso que dá o sentido da regra. "Em vez 
de pensar a humanidade como determinada por leis lógicas e matemáticas, consideremos que a prática humana é que estabelece regras para os homens." ${ }^{50}$

Nessas palavras da professora Maria Odila é igualmente possível perceber como o jovem Sérgio Buarque estava antenado com o que havia de mais avançado no pensamento filosófico ocidental e que a sua defesa intransigente da liberdade não só nada tinha de ingênua como pôde encontrar ressonâncias nas reflexões de alguns dos mais complexos filósofos do século XX, como Ludwig Wittgenstein, por ela mencionado, e Martin Heidegger, de quem cito - para concluir este capítulo - algumas palavras sobre a liberdade que de algum modo, me parece, ecoam aquelas de "Perspectivas" e que também, mesmo numa tradução, parecem participar tanto da reflexão filosófica como da poesia:

A liberdade é o que aclarando encobre e cobre, em cuja clareira tremula o véu que vela o vigor de toda verdade e faz aparecer o véu como o véu que vela. ${ }^{51}$

\footnotetext{
${ }^{50}$ Maria Odila da Silva Dias, "Estilo e método na obra de Sérgio Buarque de Holanda", Sérgio Buarque de Holanda: vida e obra, p. 73-4.

51 "A questão da técnica", Ensaios e conferências, p. 28.
} 


\section{CAMINHOS E DESCAMINHOS EM MEIO ÀS MONTANHAS: OS DOIS MUNDOS DE ITABIRA EM TRÊS ROMANCES CORNELIANOS}

E como eu palmilhasse vagamente uma estrada de Minas, pedregosa, $\ldots$

Carlos Drummond de Andrade

Alguns anos vivi em Itabira

Principalmente nasci em Itabira,

Por isso sou triste, orgulhoso: de ferro

Noventa por cento de ferro nas calçadas,

Oitenta por cento de ferro nas almas,

E esse alheamento do que na vida é porosidade e comunicação.

De Itabira trouxe prendas diversas que ora te ofereço: este São Benedito do velho santeiro Alfredo Duval; esta pedra de ferro, futuro aço do Brasil;

este couro de anta, estendido no sofá da sala de visitas; ...

Carlos Drummond de Andrade 


\subsection{O candeeiro e a lâmpada elétrica}

De joelhos, com o rosto entre as mãos, e apoiado ao meu leito, revi-me criança, e lembrei-me da transformação que nela se fez, em momentos, e com grande perturbação da minha alma infantil, quando se deu a mudança da luz do gás para a eletricidade em nossa casa.

Sucedendo à luz suave e difusa do bico que se mantinha sempre aceso em meu quarto, com sua borboleta azul e ouro vacilante e crepitando misteriosamente, veio a luz nova, muito branca, cortar as sombras em secos e compactos blocos.

(Fronteira, p. 149)

Em Fronteira, o inanimado se anima, ganha vida, ganha alma na medida mesma em que o animado por excelência, o homem, aquele que é dotado de alma, de anima, torna-se um des-almado, não no sentido corrente de cruel ou perverso, mas em seu sentido literal, desprovido de alma ${ }^{1}$, ou ainda des-humano, aquele que perdeu a própria humanidade. Esse quiasmo - manifesto, no trecho que a seguir se transcreve, na igreja que, num ato volitivo, parece querer esmagar o sujeito, e mais ainda, pois que não há então o atenuante do indicativo de comparação, nos degraus que se atravessam de surpresa no caminho do narrador-personagem, enquanto este, por sua vez, caminha maquinalmente, "como se andasse em sonho, além, talvez na morte" - esse quiasmo é uma constante em toda a narrativa e pode-se conjeturar se não seria uma figura fundamental na estrutura do romance como um todo.

Tão grande era o meu ensimesmamento que me assustei quando percebi que roçava, há muito tempo, uma mesma muralha, formidável e maciça, que parecia querer esmagar-me com sua sombra intensa, violentamente recortada no solo, em contraste de roxo e amarelo.

Andei mais depressa, na preocupação repentina de encontrar o fim daquele peso interminável, e quase caí sobre uns degraus de pedra, que se atravessaram de surpresa no meu caminho.

Eram de uma porta lateral, e devia estar só cerrada, porque cedeu unicamente com a pressão de meu corpo, quando nela me apoiei, e achei-me, sem

\footnotetext{
${ }^{1}$ É nesse mesmo sentido e valendo-se da mesma separação interna do vocábulo que Guimarães Rosa, em "O espelho", faz seu narrador-protagonista exclamar/indagar: "Seria eu um... des-almado?" (Primeiras estórias, p. 71). Devo essa observação ao prof. Alcides Villaça.
} 
transição, no coro da igreja, ao mesmo tempo sombrio e claro, pois a pouca luz nele reinante não conseguia escurecer a resplandecente brancura das suas paredes e o dourado excessivo de suas obras de talha.

Andei um pouco, hesitante, num movimento mecânico, sem compreender por que não voltava imediatamente, saindo da nave deserta.

Tinha as pupilas ainda deslumbradas pela luz lá fora, pelo sol da tarde, e não ouvi o ruído de meus passos, como se andasse em sonho, além, talvez na morte.

E tive a sensação de que morrera, realmente, e agora abria os olhos em um mundo distante.

Estava no território da morte, pois o que me abafara o choque dos pesados sapatos, próprios para as pedras pontiagudas das ruas eriçadas de minérios de ferro, eram os "panos" fúnebres, pois entrara justamente do lado da nave em que ficavam as sepulturas ricas e ainda novas, as últimas abertas antes da lei da proibição de enterramentos no interior dos templos.

(Fronteira, cap. XLI, p. 93, grifos meus.)

O personagem, ensimesmado, voltado para dentro, apresenta-se ou despido de vontade ou, quando parece manifestá-la, incapaz de fazer com que suas ações (ou reações) coincidam com seu débil querer. Estas dão-se então quase sempre no sentido contrário ao pretendido. Quando se apressa para afastar-se da muralha de pedra que o oprime, acaba por tropeçar nos degraus e estacar o passo. Ao apoiar-se na porta lateral, ela se abre e, se o narrador afirma que isto se deu pela pressão do seu corpo, o que mesmo assim demonstraria a preponderância do casual sobre o intencional, a imagem não deixa de sugerir uma ação como que empreendida pelo edifício, de moto próprio, com o objetivo de capturá-lo, de engoli-lo para prendê-lo em suas entranhas de pedra. A própria incompreensão sobre o que o teria impedido de voltar-se e abandonar a igreja é outro indício do auto-desconhecimento e da falta de domínio sobre si mesmo.

$\mathrm{O}$ ápice do sentimento de impotência nesse momento da narrativa é a sensação de morte. Antes mesmo de enunciá-lo, vários índices o prenunciam, desde o roxo que, junto ao amarelo, é entrevisto na sombra da igreja, passando pelo movimento mecânico até chegar ao símile da caminhada em sonho, "talvez na morte", e à afirmação direta e sem rebuços de ter a sensação de que havia morrido. O que parecia apenas um estado de espírito - tudo caminhava nessa direção - concretiza-se ao final do trecho citado, pois que o personagem penetrara, de fato e não na imaginação, no "território da morte", no 
lado da nave onde eram sepultadas, muito provavelmente, as pessoas influentes do lugar. Há assim uma indistinção entre a interioridade do sujeito e o que lhe é externo, entre o que está dentro de si e aquilo que seus sentidos apreendem, a despeito de (ou exatamente por) se encontrar mergulhado em si mesmo. É esse esfumado de linhas e contornos o que provoca o estranhamento no leitor logo no início desse capítulo quando vê materializar-se a muralha que chegara a supor fosse tão-somente metáfora do fardo da existência ou do peso da culpa sobre o personagem.

Há no romance um jogo entre continuidades e descontinuidades. As pedras que fazem a muralha da igreja e as ruas da cidade - a Itabira da infância do escritor literariamente recriada - são continuidade da montanha escarpada prenhe desse minério duro e maciço, que continua igualmente no coração dos homens ${ }^{2}$, caracterizados sobretudo por um fechamento extremo ao outro. Nesse sentido, a igreja "formidável e maciça", imagem da própria montanha, parece representar analogicamente o homem encerrado em si mesmo. É assim que aquelas continuidades contrastam com as descontinuidades entre os próprios homens e entre o homem e si mesmo, apesar de seu ensimesmamento, como vimos na distância entre o seu querer e o seu agir. A própria continuidade aludida não é absolutamente harmônica. Muito ao contrário, ela é feita de fricções e atritos entre os elementos constituídos, por assim dizer, da mesma matéria. A sombra da muralha da igreja é um peso interminável que parece querer esmagar o sujeito, enquanto os degraus de pedra pretendem lançá-lo ao chão em violenta queda. Por outro lado, as "pedras pontiagudas das ruas eriçadas de minério de ferro" (grifos meus), que encontram correspondência na aspereza hostil do terreno montanhoso, voltam-se contra os homens, que tentam se proteger utilizando sapatos próprios para caminhar sobre o que mais parece touceiras de espinhos. Em meio a essas continuidades e descontinuidades, os personagens surgem sempre marcados por uma incomunicabilidade inultrapassável, por um sofrimento agudo e inarredável e por uma tristeza congênita.

O abrir da porta da igreja faz-nos lembrar dos filmes de suspense e terror ${ }^{3}$, e o mesmo pode ser dito da entrada involuntária naquele espaço tomado pelas sepulturas. A paradoxal coexistência de luz e sombra no interior da igreja e os sentidos - a visão e a

\footnotetext{
${ }^{2}$ Não há aqui como não lembrar da "Confidência do itabirano", de Drummond, que serviu de epígrafe a este capítulo: "Noventa por cento de ferro nas calçadas. / Oitenta por cento de ferro nas almas. / E esse alheamento do que na vida é porosidade e comunicação."

${ }^{3}$ Vivendo entre São Paulo e o Rio de Janeiro, é mais do que provável que Cornélio tenha assistido a alguns desses filmes.
} 
audição - que ali não funcionam adequadamente são outros elementos misteriosos que provocam um sentimento de estranheza no leitor. $\mathrm{O}$ movimento mecânico do sujeito, por sua vez, é tema do ensaio clássico de Freud sobre o estranho tendo como mote o conto de Hoffmann ${ }^{4}$. Resta saber se esses elementos misteriosos encontram contrapartida na linguagem do escritor para além mesmo do mistério construído pelas circunstâncias do relato. Em termos sintáticos ou morfológicos, não haveria algo que ative e reforce o mistério presente nos elementos de sentido?

O que encontramos de mais visível quando procuramos reparar um pouco mais atentamente na linguagem do texto há pouco reproduzido é a estrutura dos parágrafos. Cada um deles comporta apenas uma frase, mais ou menos longa, de todo modo sempre uma só frase. Se continuamos a análise até o fim desse capítulo, vemos que apenas um parágrafo compõe-se de duas frases. Afora essa idiossincrasia, não parece haver nada que do ponto de vista gramatical possa ser visto como tendente a fugir das regras ou a enfatizar o misterioso ou o sombrio. Os períodos são quase sempre compostos, ora por subordinação, ora - talvez com maior frequiência - por coordenação. Não há sequer, como seria talvez de se esperar, uma utilização mais freqüente da voz passiva. Ao contrário, há um predomínio quase total da voz ativa mesmo nos momentos em que o sentido sugere a passividade do sujeito: me assustei, percebi, roçava, andei, caí, me apoiei, achei-me, andei (novamente), voltava, ouvi, andasse, tive, estava, entrara. A "ação" dos seres inanimados, por seu turno, é dada igualmente na voz ativa: parecia querer esmagar-me, se atravessaram, cedeu, conseguia escurecer, abafara. A única ocorrência da voz passiva no trecho transcrito aparece em: Tinha as pupilas ainda deslumbradas pela luz lá fora, pelo sol da tarde. Não há, por fim, ocorrência de oração sem sujeito ou de sujeito indeterminado.

Nessa rápida análise, ganham realce o predomínio da voz ativa na descrição das ações do sujeito e o contraste com a inércia com que essas ações são realizadas. $O$ personagem parece muito mais deixar-se levar por uma vontade alheia do que por uma intenção própria e consciente. O móvel de suas ações é externo e desconhecido dele mesmo. O fato de tais ações corresponderem a verbos intransitivos e, portanto, impróprios para utilização na voz passiva é uma questão menor e não parece ter grande valia na reflexão sobre a motivação do contraste aludido. Colocado ao lado deste, um outro contraste talvez nos ajude a melhor compreendê-lo. Trata-se da descrição da

\footnotetext{
${ }^{4}$ Sigmund Freud, "O Estranho", História de uma Neurose Infantil e Outros Trabalhos, vol. XVII, Obras Completas.
} 
paisagem e do ambiente que cerca e envolve esse sujeito voltado para si. Essa descrição, embora no fragmento em questão não seja tão minuciosa ${ }^{5}$, é de grande plasticidade. De imediato mentalizamos essa igreja majestosa em sua rusticidade, essas ruas irregulares recobertas de pedra, os degraus também de pedra que atravessam o caminho, o coro sombrio como que iluminado pela brancura das paredes caiadas e pelas imagens de um dourado resplandecente. Como foi sugerido, essas imagens exteriores contrastam fundamente com o ensimesmado do sujeito, e também com o mistério de que são cercadas as coisas. Se, no caso do misterioso, Mário de Andrade já havia enfatizado o quão mais terrificante é o mistério fundado na realidade mais palpável, é possível talvez dizer que o contraste apontado entre passividade e atividade também só faz crescer o mistério. É na medida em que a sintaxe não compartilha da estranheza do sentido que este se torna mais sombrio. É quando tudo está muito claro do ponto de vista da linguagem - isto é, quando não há dúvida sobre quem, gramaticalmente falando, pratica a ação - que o sentido do que é dito torna-se mais misterioso. É porque as ações do narrador-protagonista são descritas na voz ativa que sua passividade torna-se mais estranha.

Outros elementos que contribuem para caráter misterioso do episódio podem ser entrevistos em uma ou outra palavra ou expressão que surgem num contexto relativamente inesperado: "recortadas", "panos fúnebres", "eriçadas”. Essas são, como se pode ver, pelo menos no trecho analisado, em número restrito. Essa relativa parcimônia reforça assim o contraste entre a narrativa e o narrado. $\mathrm{O}$ estranhamento, então, residiria sobretudo no choque entre a plasticidade das descrições vazadas numa sintaxe relativamente usual e a inação do sujeito e o misterioso de seu agir maquinal contrapostos à vivacidade hostil dos seres inanimados.

No capítulo XXIX, o narrador encontra Maria Santa a contemplar um quadro feito de uma caixa oblonga com tampo de vidro em que foram espetados com alfinetes besouros, caramujos, borboletas e até mesmo pássaros e beija-flores. Teria sido feito, explica Maria Santa, pela Marquesa de Pantanal e, segundo o narrador, ela havia posto "os animaizinhos mortos, [...] sem simetria, sem a menor preocupação de arte" e ao vêlos ele acabava por reviver "toda a angústia daquela mão distraída, que pregava aqui e ali, como ao acaso, os 'carneirinhos' dourados e crespos, ...” (p. 65-6) Exatos quarenta

\footnotetext{
${ }^{5}$ Em A menina morta, esse procedimento será levado às últimas consequiências, como veremos.
} 
capítulos depois (capítulo LXIX), o que já fora causa talvez de um certo desconforto por parte do leitor ecoa agora de modo muito mais assustador, pois é no corpo de Maria Santa que a multidão de visitantes espeta os alfinetes, em meio a exclamações, prantos e soluços, certos de presenciarem um milagre e ansiosos por obterem uma relíquia. Depois, é narrado como, no dia seguinte, outros se aproximam e espetam "novos alfinetes em seus braços, furtivamente, com fria curiosidade, com o pretexto de se tornarem eles, depois, preciosas relíquias, que serviriam de socorro e alívio para muitos males" (p. 153; grifo meu). E, na noite em que o narrador iria velar Maria Santa, um "último visitante, depois de olhar-nos de soslaio, e tendo espetado, furtivamente, um alfinete no braço de minha amiga, se retirou como um ladrão, esbarrando nos móveis e não sabia onde esconder as mãos”. (p. 155)

Associam-se assim o sacrifício de pequenos animais, espetados num tabuleiro, como resultante da insuportável angústia humana, ou como busca de alívio dessa angústia por meio da passagem de vítima do sofrimento àquele que o inflige, e o espetar de alfinetes nos braços de Maria Santa pela multidão anônima, seja por estar convencida do milagre e das possibilidades de cura daquelas relíquias, seja por mera e fria curiosidade. Por tosca ou grotesca que fosse, aquela caixa com tampo de vidro pretendia-se uma obra de arte, deixada como herança para ser guardada, vista e mostrada a outras pessoas. Para os que a contemplavam, não estava descartada a possibilidade de certa satisfação vicária ou pelo menos algum abrandamento de suas dores ao observarem os animaizinhos espetados por outras mãos. Maria, por sua vez, era vista como santa, e aqueles que nela cravavam alfinetes ou eram católicos fiéis que misturavam em suas crenças práticas mágicas e religiosas, ou eram aqueles que haviam perdido a crença e se utilizavam daquele expediente apenas para matar a sua curiosidade ou para exercer o seu sadismo. Não seria assim que um e outro grupo encontrariam alívio para suas próprias angústias? Parece que nos encontramos então num território em que se sobrepõem arte e religião, por um lado, e religião e magia, por outro, e onde coexistem dois mundos, um que se concebe como "moderno", certo de ter deixado para trás superstições e crenças populares, parte dele acreditando mesmo ter superado a própria religião, e um outro que insiste em manter-se "atrasado", arraigado a tradições imemoriais e indiferente aos supostos avanços de uma ciência que, curiosamente, tem como dois de seus procedimentos mais emblemáticos a análise fria e a coleção e classificação dos espécimes. De certo modo, talvez aqui também não seja inadequado lançarmos mão da figura do quiasmo ou pelo menos da inversão. Maria Santa observava 
os bichinhos cravados com alfinetes e é ela agora quem os tem cravados na própria pele. O que é uma obra de arte grosseira pode ser instrumento da ciência e, invertido ou subvertido, é imagem de práticas ligadas à magia e à religião.

Centrado no estudo de um contexto muito diverso, a admirável obra de Keith Thomas sobre a religião e o declínio da magia talvez possa nos ajudar a ampliar a compreensão sobre essas questões, até porque, para além das enormes e óbvias diferenças, não é difícil perceber algumas afinidades entre a Inglaterra e a Europa medievais e o Brasil da passagem do século XIX para o XX, bem como aquele recriado por Cornélio Penna. Sobre as relações entre religião e magia, afirma o historiador inglês: "The line between magic and religion is one which it is impossible to draw in many primitive societies; it is equally difficult to recognize in medieval England."6 Sente-se ainda mais essa impossibilidade diante do catolicismo, que nunca se furtou a assimilar elementos do paganismo e de outras religiões e a apropriar-se de rituais, práticas e lugares sagrados dedicados à magia e ao culto de deuses pagãos, modificando-os e associando-os aos santos e mártires cristãos, e que, por outro lado, com seus dogmas, cerimônias e rituais, nunca deixou de ser uma fonte muito rica ou um verdadeiro "reservatório de poder mágico" para todo aquele que se dispusesse a praticar a magia ou, se quisermos trazer essas reflexões para ainda mais perto de nós e da literatura corneliana, especialmente no que se refere a seu último romance, para aqueles que não tinham a liberdade de celebrar seus próprios cultos, proibidos pela Igreja, e só puderam mantê-los na medida em que associaram seus deuses aos santos cristãos e seus rituais aos ritos católicos, dando origem às inúmeras formas de sincretismo religioso. $\mathrm{E}$ ao final dessa obra monumental, K. Thomas acaba por não só relativizar a linha divisória entre magia e ciência e entre magia e medicina, como por mostrar a permanência em plena contemporaneidade de diversas práticas mágicas e ritualísticas, bem como crenças em astrologia, na leitura da sorte e do futuro, no poder de amuletos e talismãs, além de superstições de todo tipo ${ }^{7}$. Não deixa ainda de se referir, por meio da citação de Jacob Burckhardt, ao racionalismo como sendo a religião do século XIX para

\footnotetext{
${ }^{6}$ Keith Thomas, Religion and the Decline of Magic: Studies in Popular Beliefs in Sixteenth- and Seventeenth-Century England, p. 57.

7 "Today astrologers and fortune-tellers continue to be patronized by those for whom psychiatrist and psycho-analysts have not provided a satisfactory substitute. The presence of horoscopes in the newspapers and of lucky mascots in cars is consistent with a recent investigator's conclusion that 'about a quarter of the population... holds a view of the universe which can most properly be designated as magical'." (Idem, ibid., p. 799)
} 
poucos, enquanto a magia o era para a maioria ${ }^{8}$. Se no episódio do milagre de Maria Santa reconhecemos a figuração de práticas que podem ser vistas como permanência no Brasil do final do século XIX e começo do XX de suas similares da Europa medieval ${ }^{9}$, podemos também perceber que aí se encontra uma mistura que é fundamentalmente moderna. $\mathrm{O}$ contraponto ao misticismo e ao arraigado de práticas ancestrais não é quase nunca explícito, mas sugerido, por exemplo, na menção àquela curiosidade fria e no milagre que acaba por falhar ou fracassar com a morte de Maria. Mais fortemente contrastante com o arcaico do episódio é o modo como são figurados o narradorpersonagem, que vaga ensimesmado pela mesma casa em que a multidão se acotovela para aproximar-se da Santa, encerrado em si mesmo e em sua interioridade hipertrofiada, imerso em seus pensamentos ao tempo em que age de modo maquinal e inconsciente, como um autômato, incapaz de reconhecer-se a si mesmo, e a própria Maria, com suas dúvidas, seu sentir-se igualmente estranha e estrangeira, sua incompreensão dos outros e de si mesma, sua sensação, assim como o narrador o sentia, de estar representando, e finalmente a sua hesitação insolúvel entre ser santa e ser mulher.

Ao reconstituir o que se passava no quarto de Maria Santa por meio da imaginação e dos ruídos que chegavam até ele, o narrador volta-se uma vez mais para si mesmo e para suas angústias e, em busca de refúgio, tenta reviver a infância. Num relato de tom proustiano, de que um trecho serviu de epígrafe a este item, vemos o narrador rememorar a passagem da luz do gás para a luz elétrica e os efeitos dessa mudança nas noites que se seguiram a ela. Acostumado à suavidade e aos volteios da luz difusa, "borboleta azul e ouro", o menino vê-se no quarto diante da luz nova, branca, produtora de sombras secas e compactas, e as noites tornam-se longas e cheias de angústia, e a infância, banidos os fantasmas propiciados pela luz do lampião a gás, ainda

\footnotetext{
${ }^{8}$ Idem, ibid., p. 798.

${ }^{9}$ Sobretudo no que se refere à religião em geral e ao catolicismo em particular: "Nosso velho catolicismo, tão característico, que permite tratar os santos com uma intimidade quase desrespeitosa e que deve parecer estranho às almas verdadeiramente religiosas, provém ainda dos mesmos motivos. A popularidade, entre nós, de uma Santa Teresa de Lisieux - Santa Teresinha - resulta muito do caráter intimista que pode adquirir seu culto, culto amável e quase fraterno, que se acomoda mal às cerimônias e suprime as distâncias. É o que também ocorreu com o nosso menino Jesus, companheiro de brinquedo das crianças e que faz pensar menos no Jesus dos evangelhos canônicos do que no de certos apócrifos, principalmente as diversas redações do Evangelho da Infância. Os que assistiram às festas do Senhor Bom Jesus de Pirapora, em São Paulo, conhecem a história do Cristo que desce do altar para sambar com o povo. // Essa forma de culto, que tem antecedentes na Península Ibérica, também aparece na Europa medieval e justamente com a decadência da religião palaciana, superindividual, em que a vontade comum se manifesta na edificação dos grandiosos monumentos góticos." (Sérgio Buarque de Holanda, Raízes do Brasil, pp. 109-10)
} 
mais solitária e mais triste. Não se trata aqui também de uma simples passagem, não só porque demorou muito tempo para que uma substituísse a outra, existindo ainda hoje lugares onde ambas coabitam ou em que a luz elétrica não chega, mas porque o personagem ainda adulto carrega consigo as lembranças muito vivas daquele outro tempo e daquela outra luz. Ademais, há um predomínio quase total na descrição dos espaços interiores de velas e lampiões em meio a pelo menos uma referência aos postes de luz elétrica.

No episódio da entrada na igreja em que me detive de início, o narradorprotagonista, tendo descrito o modo como nela adentrou pelo lado dos túmulos, faz uma observação aparentemente casual sobre a lei que passou a proibir "os enterramentos no interior dos templos". Pode-se dizer agora que essa observação aparentemente fortuita também aponta para o fato de que o sentido do título do romance não se resume, por fundamental que seja, à dicotomia entre razão e loucura, sentido que o próprio escritor se encarregaria de explicar no interior mesmo do relato, por meio das alusões à "fronteira de minha razão" ou à "fronteira da loucura" (respectivamente, p. 118 e 147, grifos meus), e sobretudo pela afirmação no epílogo de que "a oposição entre o mundo real e o mundo interior resultante dessa retirada voluntária [por parte do autor do relato] tornou-se uma luta angustiante de fronteira da loucura, e daí o título que resolvi dar a este livro" (p. 182, grifo meu). A fronteira é também aquela entre dois mundos que convivem lado a lado e que se chocam o tempo todo, e que respondem pelas tensões entre o homem e o que o cerca, entre o homem e seus semelhantes e entre o homem e seu próprio eu, tensões em grande parte responsáveis pela angústia e pelas descontinuidades a que se fez alusão. Que mundos são esses? Um mundo que não via problema algum em enterrar os mortos dentro das igrejas e um outro que edita leis no sentido da proibição desses antigos costumes fundados até então no direito consuetudinário; o mundo das crenças nos milagres e um outro em que os milagres não mais ocorrem; um mundo de homens que nunca saíram de sua cidade natal e um outro dos que conheceram os grandes centros $\operatorname{urbanos}^{10}$; o mundo das velas, dos lampiões, dos candeeiros, e o mundo da luz das lâmpadas elétricas. Mais do que uma substituição que esteja ocorrendo de um mundo arcaico por outro, moderno, temos em Fronteira uma superposição entre eles, ao que parece sem perspectiva de superação de seus

\footnotetext{
${ }^{10} \mathrm{O}$ narrador-protagonista não precisa de onde vem na longa viagem em que retorna a Itabira, "como alguém que volta da prisão para o país natal", mas em outros momentos da narrativa há menções a Ouro Preto e ao Rio de Janeiro.
} 
conflitos ou mesmo de predomínio de um pelo outro. Por isso a palavra "fronteira", no sentido geográfico mesmo, é muito adequada para definir essa convivência (conflituosa) de contrários, pois que nesse sentido não significa a linha exata onde dois países ou territórios diferentes confinam, isto é, o que se denomina "limite", mas a faixa onde, de um e de outro lado, se mesclam inúmeros elementos, eventualmente muito diferentes, de um e de outro ${ }^{11}$. Essa coexistência parece tornar-se ainda mais tensa diante da situação de decadência da cidade encravada nas montanhas e de seus casarões, que vêem chegar o novo, ainda que timidamente, no momento mesmo em que tudo parece envelhecer irremediavelmente.

É claro que não existe e nem deve ter existido lugar algum em que não tenham convivido diferentes temporalidades, diferentes mundos. Dificilmente, porém, encontraremos exemplo mais evidente da coexistência (carregada de conflitos e tensões) de mundos tão diferentes, temporalidades tão distantes como aqueles que se encontraram - e se chocaram - no Brasil (e quem sabe no Ocidente como um todo) do final do oitocentos e começo do século seguinte, e que talvez se confrontem até hoje. As novas descobertas e o tremendo avanço da ciência, as inovações tecnológicas, o surto da industrialização, o desenvolvimento acentuado das comunicações e dos transportes, o vertiginoso crescimento das metrópoles, a mudança dos centros de poder econômico e político do campo para as cidades, entre outras coisas, tornavam-se uma realidade mesmo num país periférico como o Brasil ${ }^{12}$ e faziam cada vez mais dramático, sobretudo em países desse tipo - seja por seus "efeitos colaterais", seja por seu alcance relativamente limitado e desigual, seja ainda por terem lugar em meio a estruturas arcaicas e antiquadas -, o contraste entre o que havia de mais moderno e de mais $\operatorname{atrasado}^{13}$. O fato de Cornélio não tratar explicitamente dessas questões não significa que elas não tenham uma importância fundamental na estrutura e no enredo do romance.

\footnotetext{
${ }^{11}$ Curiosamente, só fui notar esta diferença por intermédio de minha filha, Lígia, e seus estudos de geografia na $6^{\mathrm{a}}$ série. Esse sentido de fronteira adquire admirável concretude no inglês borderland.

${ }_{12}$ É preciso talvez dizer que aqui todo esse processo ocorreu em escala infinitamente menor que nos países centrais, e mesmo nossas "metrópoles" eram muito provincianas sobretudo quando comparadas às metrópoles européias ou americanas. Devo a Nelson Aprobato Filho o conhecimento de fotos de LéviStrauss da São Paulo dos anos 30 que mostram localidades hoje centrais em São Paulo que parecem antes imagens de sítios e fazendas distantes da zona urbana.

${ }^{13}$ Em Raízes do Brasil, ao tratar do processo revolucionário em curso no Brasil "há três quartos de século" e que envolvia a mudança do centro de gravidade dos domínios rurais para os urbanos e "o aniquilamento das raízes ibéricas de nossa cultura", Sérgio Buarque de Holanda vê como os próximos passos desse processo "a dissolução lenta, posto que irrevogável, das sobrevivências arcaicas" e a revogação de nossa "velha ordem colonial e patriarcal", para afirmar em seguida: "Estaríamos vivendo assim entre dois mundos: um definitivamente morto e outro que luta por vir à luz”. (p. 135, grifo meu)
} 
Os seres inanimados mostram-se agressivos, como vimos, mas é a natureza, em primeiro lugar, que se volta contra o homem, convertida numa entidade francamente hostil ${ }^{14}$. Submetido a essa opressão, o homem busca seu semelhante apenas para sentir o irremediável de sua solidão extrema ${ }^{15}$. A imagem mais terrível desse isolamento é a história dos "bexiguentos" ouvida em criança pelo narrador: dois trabalhadores atacados pela varíola foram conduzidos para uma casa abandonada na encosta de uma montanha. Alguém sempre lhes levava alimentos e remédios, e apenas os lançava através da grade do jardim. A princípio vinham os dois ao portão até que um dia veio um só, e as reflexões sobre a desconfiança de ambos de que um deles pudesse fugir ou não repartir algum alimento ou remédio apanhado não deixam de sugerir que um tenha matado o outro, e mesmo o "sobrevivente" deixa um dia de aparecer ao portão, nunca mais se podendo descobrir o que realmente acontecera, pois ninguém mais ali pusera os pés. Como no próprio romance, misturam-se nessa história o abandono, o sofrimento, a violência e o mistério insondável ${ }^{16}$.

É nessa terra desolada que o narrador-protagonista intenta ainda a comunhão, mas, como não poderia deixar de ser, num movimento marcado por alguns avanços e muitos recuos e, na verdade, muito mais hesitante do que aquele empreendido por Maria Santa na sua direção. Embora não saibamos praticamente nada sobre as relações entre ambos, há alguma sugestão de parentesco. Primos, talvez? Como quer que seja, há a santidade de Maria, e a suposta Missão que recebera, e a figura de Tia Emiliana a se interpor entre eles. Ao se instalar naquela casa "feita de acordo com o cenário de montanhas que a cercavam de todos os lados", habitação hostil como a natureza e, como ela, tão pouco acolhedora, o narrador começa a sentir a dubiedade dos sentimentos que Maria parece nutrir por ele, até começarem a se estreitar as relações entre ambos em meio ao mistério que permeia esses capítulos iniciais.

\footnotetext{
14 “os ramos curvam-se para me fustigar o rosto, movidos por silenciosa hostilidade" (p.22); "para mim, todo este monstruoso panorama representa apenas um motivo estrangeiro e hostil, que me assusta, que me dá medo pelos seus excessos e pela sua morte mágica" (p.109); "As folhas, nas árvores, murmuravam dia e noite, e as pedras gemiam, como o eco de uma inumerável e sombria multidão que cerrasse as fileiras em torno de nós, em um cerco tenaz e fantasmagórico." (p. 120).

15 "absoluto isolamento em que me colocavam"; "a persistência da muralha invisível que se erguera entre nós, pela manhã, e impedira que nos reconhecêssemos" (p. 26); "a certeza de que são estrangeiros, e talvez inimigos um do outro" (p. 52); "a sensação de isolamento que me apertara as fontes todo o tempo, e que me sufocara entre as paredes do quarto" (p.102); "todos os desiludidos, todos os traídos, os semsorte, os explorados, que se juntam, estrangeiros, em um grupo subitamente homogêneo" (p. 139).

${ }^{16}$ Esse episódio como que encontra um eco numa passagem no capítulo LXXVIII, em que o narrador conversa com seu "amigo das consultas de Tia Emiliana": "Vivemos como sitiados, como prisioneiros que se entreolham, raivosos, pressentindo a chegada de uma desgraça, que não sabem qual é, mas que deve ser, infalivelmente, dolorosa e sem perdão?” (p. 167)
} 
Coberto de mistério é também o que de fato acontece entre eles ao longo de todo o livro, sendo seus encontros e conversas em grande medida enigmáticos e obscuros. Num diálogo no capítulo XXVIII, Maria Santa, depois de mencionar o suposto ódio do personagem-narrador por Tia Emiliana, afirma conhecer o que ele quer e conclui de modo dúbio: "Eu sei o que é, mas não são todos que recebem a Graça." E ao fitá-la, o personagem percebe com espanto que ela havia modificado o penteado que usava há tantos anos e lembrava agora, com seus "dois bandós muito lisos e negros", uma imagem de "Madona" popular. Diante desse olhar (de desejo?), ela se retira de sua presença chamando-o demônio. Depois de algumas fugas de espírito e fugas de fato, avanços e recuos, os dois personagens se encontram no "jardim silencioso e devastado" quando sentem uma misteriosa presença. É algo pestilento, pois Maria Santa afirma que deve provir "de algum animal morto". Ao comentar sobre o esquisito do frio, porém, cala-se subitamente, pois que a presença invisível acaba de passar entre eles. O medo atribuído por um ao outro é o medo de ambos, e é Maria Santa quem acaba por vencêlo, é ela quem toma a iniciativa:

Senti, depois, uma mão trêmula agarrar-me o braço, e unhas em garra enterraram-se na minha carne. Um bafo quente chegou-me até a boca, adocicado e morno, e senti que todo o meu corpo se encostava a outro corpo, em um êxtase doloroso e longo, inacabado e insatisfeito... (p.77)

A associação entre desejo e pecado é reafirmada ao final do capítulo quando o narrador menciona que, em seu quarto, procurou "lavar a boca, o rosto e as mãos, como o fazem os criminosos, para apagar os vestígios de seu crime...” E no capítulo seguinte descreve o choro e a dor de Maria Santa, ao dizer-se a última das mulheres, e o modo como ele passa das palavras de conforto para os gestos, enlaçando-lhe a cintura e beijando suas espáduas. Mas, se não há agora o subterfúgio da omissão do nome de Maria Santa, há um outro que evita a menção direta ao que é apenas sugerido: "Em um movimento maquinal ela me enlaçou, e, sem uma palavra, sem volúpia, num pobre gesto, senti passar de novo, sobre nós, a fatalidade." A fala seguinte de Maria Santa parece ser o comentário sobre a inevitabilidade do pecado e o inescapável de suas conseqüências: "Somos duas criaturas miseráveis..."

No capítulo XXXV, “às ocultas de Tia Emiliana”, o personagem lê em voz alta para Maria Santa "uma velha edição do Paraíso Perdido, com a capa de couro toda 
comida, em caprichosos desenhos, pelos cupins que devoram lentamente toda a cidade do Rio de Janeiro." O próprio exemplar do livro de Milton, além de aludir ao paraíso já perdido, parece materializar em seu estado a condição humana, ela também roída e corroída, coberta por uma camada de "poeira negra e sutil". E é um exemplar no original, em língua estrangeira, que ele traduz para Maria Santa, uma "tradução hesitante, gaguejada e entrecortada de interjeições impacientes" (p.80), que ela na sua encantadora ingenuidade acredita tratar-se de "um livro de magia", como se o paraíso perdido já não pudesse ser evocado senão na chave do mágico, do encantatório, da prestidigitação. Por outro lado, o poema que não se deixa mais cantar aponta para a confusão entre as línguas, a Babel bíblica a partir da qual os homens passaram a não mais se entender uns aos outros, tornando-se estrangeiros e estranhos entre si. Pouco depois desse episódio, o narrador irá afirmar que ele, Maria Santa e Tia Emiliana se sentiam "como estrangeiros que falam línguas diferentes, reunidos pelo acaso." (p.84) ${ }^{17}$ São inúmeras as situações de interrupções, de reticências, de incompreensões, de diálogos interrompidos ou que se tornam monólogos, bem como quase o inverso disso, pensamentos em voz alta ouvidos pelo outro como se fossem tentativas de diálogo e respostas a perguntas feitas apenas interiormente. Isto é, parece haver, sim, um desejo, uma necessidade de se comunicar, mas que esbarra sempre na impossibilidade da comunicação, impossibilidade essa que não só não faz cessar o desejo como parece espertá-lo ainda mais.

E antes de se recolher definitivamente ao quarto, Maria Santa toma a iniciativa uma vez mais e uma vez mais é o narrador que lhe foge. Caminha em direção a ele, que faz um gesto para que ela pare e não mais se aproxime. Percebe então que ela traz "os ombros e os braços nus, apenas recobertos por estreita pelerina de rendas pretas, através de cujos desenhos se destacava com brilho estranho, a sua pele muito pálida e brunida." Pergunta a ele se a acha bonita, se ela estava bem. Ao levantar-se, ele sente "um perfume quente, humano, misto de sangue e sândalo" e crê que ela intenta um sacrifício para salvá-lo. Diante dessa reação, ela responde que talvez queira é salvar-se a si própria e depois, ao refletir um pouco mais, "Ou talvez... queira perder-me..." Há assim

${ }^{17}$ Em Repouso, Dodôte vê com estranheza e receio os rótulos dos remédios da farmácia de Urbano escritos "em língua morta", como observa Letícia Malard no prefácio da obra: "Bem sabia que, sob as denominações muito eruditas, debaixo da estranheza de seus invólucros, alguns daqueles antigos remédios eram talvez dos arredores da sua pequena cidade, mas o cheiro artificial, indefinível, que vinha dos armários negros, arranjados por ela mesma, que tudo colocara na ordem indicada pelos cadernos de seu sogro, tal como os deixara há muitos anos, sem que Urbano nem sequer os tocasse, tornava-os estrangeiros e ameaçadores." ("Um antiquário apaixonado", in Cornélio Penna, Repouso, Rio de Janeiro, Artium, 1998, p. 32) 
inequívocas sugestões de atração sexual entre os dois personagens, em meio a constantes alusões que entretecem a sexualidade e o sagrado, mas os personagens, depois de um avanço às vezes ousado, acabam sempre por recuar. A maior parte desses avanços, contudo, partem de Maria Santa. Os recuos, do narrador-protagonista.

Ao se aproximar o desfecho do romance, Maria Santa já não sai de seu quarto e depois nem mais se levanta da cama. E, no primeiro dia da Semana Santa, o milagre, “depois de alguns anos de interrupção", finalmente se repete. Ela fica imóvel em seu leito, iluminada por um círio, pálida e sem sentidos, e só nesse primeiro dia se levanta na presença do narrador para em seguida voltar à posição anterior, e põe-se na presença dele "a falar baixinho coisas que não se repetem". A partir do segundo dia é cercada por círios e duas imagens grosseiramente esculpidas e exageradamente cobertas com vestes teatrais, tudo preparado como num espetáculo por Tia Emiliana, que aparece segurando uma salva de prata já cheia de moedas. As caravanas de peregrinos que vêm visitá-la e à Tia Emiliana aumentam; uma multidão percorre ruidosa a casa e, diante de Maria, muitos espetam alfinetes em seu corpo e ela parece não senti-los. Tia Emiliana a vela todas as noites, mas numa delas, dizendo-se exausta, pede (ou ordena) ao narrador que fique a velá-la.

Contemplei, por muito tempo, o rosto de Maria Santa, impassível, imóvel, como uma estátua funeral das antigas catedrais européias, e, de repente, alguma coisa em seus ombros me chamou a atenção, e fez com que me erguesse de onde estava, e me aproximasse vivamente.

Ela estava envolta em um hábito amplo de flanela branca, que a escondia toda em grandes pregas, e desenhava castamente as suas formas, tornando-a muito longa, em linhas todas simples e de severa harmonia.

Nos ombros a túnica era presa por laços, e meus olhos, neles se fitando intensamente, me fizeram compreender, e depois ver, que estavam desatados, e deixavam entrever a carne morena e pálida das espáduas de Maria, por entre duas bordas do vestuário imaculado, que, apenas tocado por meus dedos cautelosos, caiu, para os lados, com surpreendente facilidade... 
Uma renovação lenta, como um cântico, o despertar sucessivo, ritmado, de forças novas, o palpitar, que se fazia sentir, a princípio surdo e longínquo, mas depois bem próximo, bem nítido, correu por minhas veias como as águas que invadem murmurando, a princípio hesitantes, depois em louco tumulto, a rede de irrigação de uma campina, o palpitar de um sangue mais humano e generoso, despertavam em mim toda uma vida nova, involuntária e terrível, como um festim funerário.

Passei, assim, depois, muitas horas, com o corpo voluptuosamente estendido, os membros lassos pendentes para fora da arca, onde de novo me refugiara, e cuja tampa, pesada e eriçada de tachas, me parecia de inexplicável doçura.

Gozei, com indizível tranqüilidade, da pacificação de todas as minhas inquietações, de todos os meus antigos terrores, e aquela vida animal que nascera e agora se agitava em mim, em surdina, despertava as fontes mais secretas de minha energia, sem depender de minha vontade e dos desejos mórbidos de meu espírito, que se tinham retirado para as trevas de onde tinham vindo, em bandos confusos.

(Fronteira, caps. LXXII-LXXIII, p. 155-7.)

Tudo o que acontece entre o narrador e Maria Santa resta apenas sugerido nas reticências finais e na passagem de um para outro capítulo. Os indícios, porém, de que o descobrir da nudez de Maria Santa tem exatamente o sentido bíblico são inequívocos ${ }^{18}$. A transformação do sujeito é total. Um levantamento dos substantivos utilizados no primeiro parágrafo do capítulo LXXIII basta para confirmá-lo: renovação, cântico, despertar, palpitar, água, sangue, campina, vida. Nada mais oposto a toda a narração anterior. A expressão final "festim funerário" não só não deixa de comportar o sentido de festa como não consegue fazer com que o caráter lutuoso se sobreponha (pelo menos por enquanto) à felicidade plena alcançada, cuja narração prossegue inclusive nos parágrafos restantes até o fim desse capítulo e avança mesmo pelo capítulo seguinte, em que o narrador percorre com as mãos o corpo nu de Maria Santa.

Essa união se realiza sob o signo da transgressão ${ }^{19}$, tendo em vista a suposta santidade de Maria, aquela que, segundo se acreditava, via e recebia a própria Virgem, o

18 “Toda a consecução erótica tem por princípio a destruição da estrutura do ser fechado, que é, no estado normal, um participante da acção. / A acção decisiva é o desnudamento. A nudez opõe-se ao estado fechado, ou seja, ao estado de existência descontínua. É um estado de comunicação que revela a procura duma possível continuidade do ser, para lá do isolamento a que cada um de nós está votado." (Georges Bataille, $O$ erotismo, p. 16)

19 “... l'interdit n'en est pas moins une invite, en même temps qu'un obstacle." (Georges Bataille, "Emyle Brontë”, La littérature et le mal, p. 17.) 
grau de parentesco entre ela e o narrador sempre encoberto a sugerir uma possível relação incestuosa, e o estado em que ela se encontrava, inconsciente ou semi-morta, o que faz com que o ato beire a necrofilia, de que há ressonâncias na expressão comentada há pouco. O sentimento de desamparo, de exílio, de estranhamento, reflexos todos da profunda desumanização que tomou conta dele, ele sente agora superar. $O$ ser descontínuo retoma momentaneamente sua continuidade perdida por meio do ato sexual, e especialmente de um ato sexual transgressivo. É, a despeito disso (ou exatamente por tudo isso), um momento de plenitude, de vida, de libertação ${ }^{20}$. É o renascimento daquele que se sentia morto em vida, a sua reconciliação com a natureza e com os objetos, percebidos até então como inimigos figadais. A própria tampa da arca onde se deita, "eriçada de tachas", lhe parece de uma doçura inexplicável. Inúmeros outros índices dessa transformação se espalham ao longo dos capítulos LXXIII e LXXIV $^{21}$. Uma vida animal nasce dentro dele e o mecânico dá lugar ao orgânico; o que se via como um autômato ou um fantasma sente-se irrigado pela seiva humana; aquele que se sentia incompleto sente-se agora pleno, sentindo o próprio corpo e o corpo do outro; o que era estranho e estrangeiro torna-se familiar.

O seu acabamento, a sua completude, a sua humanidade, a sua vida, enfim, só pode ser encontrada na fusão com o outro. Ele, que tanto fugira quando ela o procurara, realiza finalmente o encontro. Luís Bueno, aproximando a religiosidade corneliana da perspectiva de Denis de Rougemont, exposta em $O$ Amor e o Ocidente, afirma ser assim que se realiza "o verdadeiro milagre de Maria Santa", a prática da verdadeira caridade, a "virtude cristã que sintetiza a importância do próximo, do outro". ${ }^{22}$ Antes de uma

\footnotetext{
20 "Parece a quem ama que só o ser amado (...) pode, neste mundo, realizar o que nossos limites proíbem, ou seja, a plena confusão entre dois seres, a continuidade entre dois seres descontínuos"; "sem a evidência de uma transgressão, não experimentamos esse sentimento de liberdade necessária à plenitude do acto sexual" (Id. Ibid., p. 19.) Luiz Costa Lima afirma praticamente o mesmo, ressaltando ainda, na narração que se segue a esse trecho, a ligação que se estabelece entre o gozo sexual e a esfera do religioso e do sagrado: "Não se trata de uma simples sensação de conforto físico, pois o capítulo inteiro combina os signos do animal que, satisfeito, pensa na ordem 'só agora revelada, do destino'. E à reflexão não é estranha a presença de termos ligados à área da experiência religiosa - cântico, futuro iluminado, domínio sadio e sagrado, ordem do destino." (A perversão do trapezista: o romance em Cornélio Penna, p. 66)

21 “... aquela vida animal que nascera e agora se agitava em mim, em surdina, despertava as fontes mais secretas de minha energia" (p. 157); "o nascimento, a criação muito complexa e difícil do animal que, de um salto, me deveria dominar, aplainar e destruir, talvez para sempre, as curvas e os ângulos do meu caráter incompleto, inacabado..." (p. 158); "Descobria agora que um outro mundo coexistia com o meu, e nele os seres se moviam, sentiam, amavam e viviam de uma forma que eu não compreendera ainda, apesar de suspeitar de sua existência" (p.159); "E vinham à minha boca, em confusas e irresistíveis golfadas, palavras redentoras e esquecidas de amor universal, que eu murmurava como em sonho, um sonho enorme de fecundidade, de presença, de seiva humana e eterna, que latejava com violência em mim, e espantava para bem longe fantasmas subitamente apagados e envelhecidos..." (p. 160)

${ }^{22}$ Em comentário à minha abordagem de Fronteira, Alcides Villaça mencionara a possibilidade de ser exatamente essa a Missão de Maria Santa e, assim, plenamente cumprida.
} 
santidade falhada, como a viu Tristão de Athayde, teríamos a "revelação de uma outra santidade" que não aquela esperada por todos e, principalmente, por Tia Emiliana. Sem rejeitar essa leitura, aliás bastante aguda, parece-me que a questão é um pouco mais complexa. Segundo Bataille, no Cristianismo, o erotismo é colocado para fora do campo do sagrado, que passa à esfera do profano, enquanto a sexualidade passa a ser afirmada apenas quando atende à conservação, isto é, à procriação. Assim, o erotismo é associado ao mal, ao diabólico, e - como tal - objeto "de uma condenação radical" e uma repressão violentíssima na Idade Média. A necessidade dessa repressão, porém, é índice da situação paradoxal do Cristianismo. Quando o erotismo era parte do sagrado, era também associado ao Mal, mas este também pertencia ao sagrado, e assim a "transgressão era organizada e limitada". Com a expulsão de ambos para a esfera profana, o mal e o erotismo fogem ao controle, e àquele que é condenado é concedida ao mesmo tempo a liberdade total de cometer o mal e entregar-se à licenciosidade sem controle: "O gozo do libertino corresponde ao horror do homem piedoso." É desse paradoxo que vive o cristianismo e é por isso que a transgressão no caso do narradorprotagonista de Fronteira não pode ter apenas um sentido positivo, como também - sem deixar de tê-lo - um lado negativo. Se houve milagre (e penso mesmo que teria havido), é o milagre possível num mundo em que milagres não mais ocorrem. A plenitude que o narrador alcança não só é efêmera como Maria Santa dela não participa, morrendo pouco depois. O encontro verdadeiro do outro só aconteceria de maneira plena na medida em que o outro encontrasse o um, na medida que o outro também se sentisse pleno.

Ausente o olhar de Maria Santa, são as imagens inanimadas, as figuras toscas colocadas em seu quarto, em seu artifício, que parecem auxiliar o narrador em sua tentativa de superar o sentimento de incompletude e de divisão ${ }^{23}$. Temos então um embaralhamento entre o animado e o inanimado, entre o homem e as obras que ele produz. Não há explicações fáceis e quem sabe, em muitos aspectos, não haja sequer uma explicação. De todo modo, é com essa ajuda que o narrador consegue uma vez mais sentir a plenitude, mas é mais uma vez uma paradoxal união:

\footnotetext{
23 “As imagens de Tia Emiliana, envoltas em seus mantos suntuosos de veludo, fitavam-me com seus olhos exageradamente patéticos, de onde pendiam grossas lágrimas de parafina, que escorriam sobre as faces de cor cadavérica, apesar das manchas de vermelhão, e os pesados ramalhetes de flores de metal, como mitras de bispos de pesadelo, as velas de cera, muito altas e hirtas, as rendas e franjas douradas e prateadas, em profusão, tornavam tudo que me cercava irreal, estranho, sustentando com seu ingênuo e esquisito artifício a minha pobre tentativa de vida e de humanização.” (p. 159)
} 
Não me parecia cometer um crime moral, ao desvendar vagarosamente, um a um, os melancólicos segredos daquele corpo que todo ele se me oferecia e se recusava, ao mesmo tempo, em sua longínqua imobilidade.

Era uma caridade incomensurável que ele praticava, inconsciente, mas, por isso mesmo, mais valiosa e quase divina pela sua inocência puríssima, sobrehumana. (p. 160)

Aqui, mais ainda que antes, está inteiramente ausente a humanidade de Maria, a que o narrador se refere como "ele", como "corpo", e palavras como "caridade" e "inocência” parecem assim soar ironicamente. Mais que advinda da união com Maria Santa, a impressão agora é de que a plenitude que ele sente alcançar é obtida graças ao onanismo, indício não da completude, mas da irremediável solidão do sujeito ${ }^{24}$. Por fim, a menção, ao final do capítulo, “às portas da vida..." só pode ser lida como trágica ironia, pois muito em breve será comunicada a morte de Maria Santa.

A impressão que tem então o leitor, não sendo católico e sobretudo estando desarmado no sentido de salvaguardar o suposto catolicismo de Cornélio Penna, é de que ele aqui dramatiza o insuperável desamparo de estar no mundo ${ }^{25}$. Enquanto imagens de cera criadas pelo próprio homem o contemplam em seus esforços para se tornar verdadeiramente humano, ele sente a si mesmo como se fosse um boneco disposto nas mãos de um criador feito à sua imagem, ao menos no que se refere à sua natureza caprichosa e oscilante, ou ainda sem qualquer criador de fato, como se pode depreender de uma afirmação do narrador de Fronteira, em frase plena de ressonâncias shakespearianas: "A minha vida, como a de todo o mundo, é uma série disparatada de episódios sem qualquer significação seguida e sem lógica.” (p.133) ${ }^{26}$ Pode-se dizer então que a fronteira que separa a razão da loucura se alarga dramaticamente e essa

\footnotetext{
24 Alcides Villaça havia também comentado a existência de numerosos índices que apontam para a masturbação, espalhados pelos capítulos LXXIII e LXXIV.

25 "É rigorosamente esse intervalo radical, que se estabelece entre as exigências incontornáveis da pulsão e os instrumentos de simbolização insuficientes disponíveis para o sujeito, que o discurso freudiano tardio denominava desamparo (Hilflosigkeit). É essa condição de desamparo estrutural do sujeito, posicionado entre a pressão contínua da força pulsional e a insuficiência do sistema simbólico, que funda a ética trágica do discurso freudiano no seu fechamento. Com isso, a concepção da existência de um 'mal-estar na civilização' pode se apresentar, de fato e de direito, em toda a sua radicalidade e rudeza, fundada nesse intervalo estrutural constitutivo do sujeito." (Joel Birman, Estilo e modernidade em psicanálise, p. 67) "De qualquer maneira, o projeto iluminista foi ferido de morte em o Mal-estar na civilização, considerando-se a constatação irrefutável do mal-estar, de forma que a ciência pode promover o desenvolvimento civilizatório, mas às custas da felicidade humana. Essa conclusão é uma revelação fulgurante dos limites do ideário iluminista para o sujeito, assim como dos impasses da ciência para a construção do mundo." (Id., ibid., p. 75)

${ }^{26}$ Nas palavras de Macbeth: "Life is a tale told by an idiot, full of sound and fury, signifying nothing".
} 
caracterização passa a recobrir um número muito maior de seres do que aqueles tidos como loucos, como Sinhá Gentil e Didina Americana, e um leque de experiências muito maior do que o que é comumente chamado loucura.

No capítulo LXXVIII, o narrador-personagem "dialoga" com o conhecido das consultas da Tia Emiliana e o que parece nítido nessa fala de quem está prestes a ser tomado pelo loucura é o entendimento de que esta está por toda parte, e sobretudo na zona fronteiriça onde dois mundos tão distintos se encontram:

"Por toda a parte o homem conseguiu pôr a nu as suas pedras de ferro, negras e luzidias. E sobre elas construíram suas casas, onde as famílias degeneram lentamente, e em cada uma está a loucura à espreita de novas vítimas.

"Ande à noite por aí, por essas ruas letárgicas, por entre esses intermináveis postes de luz elétrica, que clareiam com silenciosa pompa, misérias e ruínas, e ouvirá gemidos, tosses, uivos e gritos alucinantes, ouvirá, realmente, tudo isso, como se percorresse as alamedas de um grande hospício, por entre seus pavilhões gradeados.

"Já observou a voracidade sinistra dos mendigos, em contraste desesperado com a sobriedade dos ricos? [...] (Fronteira, cap. LXXVIII, p. 166)

No jogo de inversões do romance - que não é de modo algum apenas jogo, mas a consciência de que para alcançar alguma verdade há que negar o outro jogo, muito mais fácil, dos valores estabelecidos e das verdades inquestionáveis -, a loucura pode ser caminho para a revelação e talvez, a despeito mesmo da intenção do autor, uma revelação muito mais terrena que espiritual: "O senhor não sente que não poderemos nunca caminhar juntos com as coisas que nos cercam aqui, que caminhamos para fins absurdamente diferentes e que se ignoram uns aos outros?" O que o narrador parece afirmar textualmente é a incompatibilidade entre a modernidade dos postes de luz elétrica e as misérias e ruínas que pretendem iluminar. E o descompasso entre riqueza e pobreza é outro elemento fundamental em meio a outros tantos elementos que tornam inescapável nossa condição de seres vulneráveis, desamparados e estranhos uns aos outros.

É esse desamparo que, ainda nos momentos em que o personagem consegue prolongar o êxtase da união com Maria Santa, se entremostra num termo como "festim funerário", já mencionado, que aludia já tanto à morte próxima de Maria Santa como ao 
caráter contraditório do que acontecera, uma vitória que já trazia em si o amargo sabor da derrota, pois que esse momento é sempre transitório ${ }^{27}$. Por isso, como que subrepticiamente, mal é formulada a completude, ela se faz acompanhar de outros termos (pospostos ou antepostos) antitéticos e paradoxais como "delicioso pavor"; "minutos eternos"; "seiva humana e eterna". Como as pedras preciosas da Tia Emiliana que a viajante descobre serem apenas pedras sem grande valor - "ametistas, topázios, berilos, águas-marinhas, crisólitos, colofonas", "rubis, esmeraldas e brilhantes dos pobres" -, o momento de plenitude que se queria permanente e eterno mostra-se provisório, temporário e irrepetível.

Em seu próprio quarto, separado de Maria Santa, o personagem dá acordo de si, tendo sido arrastado até ele por Tia Emiliana sem auxílio algum, e agora restam apenas alguns poucos episódios, todos recobertos pelo mistério, antes da notícia da morte de Maria Santa e do enlouquecimento do narrador.

$* * * * *$

O romance é composto como um diário que só se explica (se é que se pode falar assim quando ao final restam muito mais dúvidas que certezas) no epílogo, quando o suposto editor nos informa sobre o modo como o obteve e como teria indiretamente conhecido Maria Santa. Quanto ao autor, tudo é mistério ${ }^{28}$. E é também o mistério que se espalha pelo livro em personagens e episódios que nunca são esclarecidos, o que tanto desagradou Mário de Andrade, num ensaio de impressionante acuidade em que, a despeito dessa crítica, se mostra muito bem impressionado pelo livro de estréia de Cornélio Penna ${ }^{29}$. Nesse sentido, aquele que teria transcrito integralmente o diário não só reconhece a sua ignorância e o desconhecimento ("Não é, pois, um epílogo, porque não sei o final deste romance, e quando perguntei à minha parenta quem tinha escrito este jornal, e que fim tivera, ela apenas se persignou, e desviou o olhar do meu rosto." ${ }^{30}$ ), como afirma de modo irônico e paradoxal que, se o diário "o satisfez, não seria decerto do agrado daqueles que, como eu, acham que um romance deve basear-se na 'estrita observação de factos reais', como se dizia antigamente." (p.181, grifos meus)

\footnotetext{
27 "Para todos os amantes, há mais possibilidades de gozar duma desesperada contemplação da íntima continuidade que os uniu do que poderem duradouramente encontrar-se." (O erotismo, p. 18)

${ }^{28} \mathrm{O}$ escritor procura tornar misterioso inclusive o sexo do narrador-personagem ao mencionar "o autor ou autora do manuscrito" (p. 182).

29 "Romances de um antiquário", pp. 125-8.

${ }^{30}$ P. 181.
} 
Ocorre que o mistério é incorporado como tema e como elemento de composição do romance: "Porque eu conheci Maria Santa em um só gesto de uma velha parenta minha, em cuja casa permaneci algum tempo, quando de minha viagem ao fundo dessa maravilhosa Minas Gerais, ...” (p.181) ${ }^{31}$ Aqui se cruzam ficção e realidade. De fato, depois de passar algumas semanas em Itabira, Cornélio ficara impressionado com a história de Maria Santa. Como era apenas pintor, a contava aos amigos escritores tentando interessá-los na criação de um romance sem conseguir, porém, despertar o seu entusiasmo. Resolveu então levar a cabo ele mesmo essa tarefa e o fez de modo tal a recriar o halo misterioso que se desprendia da história que se contava em Minas. É o mistério de crimes e mortes nunca esclarecidos que cercavam a "enorme fachada do sobrado, de onde tinham saído tantos enterros, tão discutidos e comentados” (p.35). O desconhecimento não é, contudo, apenas apanágio do leitor, os personagens e o próprio narrador parecem imersos tanto quanto aquele nesse mesmo clima: "sei que você tem sofrido", diz Maria Santa ao narrador, e prossegue de modo reticente: "e que o "sombrio mistério de sofrimento e mal moral' de que você me tem falado tantas vezes..." (p.54) As referências aos crimes dentro dessa família aparecem sempre de modo hiperbólico, mas sem nunca serem aclarados: "e nesse tempo só se falava no seu martírio [de Maria Santa] e nos crimes de sua família brutal.” (p.74) Esse é contudo o único momento em que um personagem alude de maneira um pouco mais explícita à natureza deles, assim mesmo de modo indireto: "Disseram mesmo que ela ia casar-se, e aqui esteve hospedado o seu noivo, que saiu desta casa para ser enterrado, e isso deu muito o que falar." (p.74) Os personagens e as relações são também envoltos em mistério. Terminado o romance, não ficamos sabendo quem é a viajante ou um homem vestido de preto, personagens cuja arbitrariedade foi tão censurada por Mário. Não nos é dito nada de mais concreto a respeito das relações de parentesco entre Maria Santa e o narrador, como vimos, bem como entre este e Tia Emiliana, e menos ainda o que o ligava à viajante. Somos igualmente mantidos na ignorância a respeito do conteúdo dos papéis deixadas pelo juiz, a que mais de uma vez faz-se menção e que misteriosamente aparecem juntos do diário encontrado, também não se sabe como, pelo seu editor.

Os oitenta e quatro capítulos são em geral muito curtos, em algumas ocasiões não atingindo sequer uma página impressa. Há geralmente continuidade de um para

\footnotetext{
${ }^{31}$ Não sei se seria tão-somente mera coincidência, mas o narrador criado por Clarice Lispector em $A$ hora da estrela, Rodrigo S. M., afirma que tudo o que irá escrever sobre Macabéa advém de ter pego "no ar de relance o sentimento de perdição no rosto de uma moça nordestina”. (p. 12)
} 
outro capítulo, embora em alguns casos seja tênue a ligação entre eles, e o mesmo se pode dizer a respeito de alguns parágrafos dentro de um capítulo, o que acabou permitindo ao escritor mudanças na ordenação de alguns deles na edição de $1953 \mathrm{em}$ relação à de 1935. Percebe-se a nítida existência de um fio narrativo, que talvez possa ser desdobrado em dois aspectos fundamentais: a) a santidade de Maria e a aproximação da Semana Santa em que se dariam os seus milagres; e b) a relação entre Maria Santa e o autor do diário e a crescente atração que um exerce sobre o outro. Em ambos Tia Emiliana desempenha um papel essencial. No primeiro, como aquela que dirige a casa e tudo o mais no sentido de que Maria Santa cumpra sua Missão; no segundo, como a que exerce vigilância sobre os dois personagens, mas que acaba propiciando a união entre eles. Quanto ao desfecho, o primeiro termina com o fracasso da missão - pelo menos do ponto de vista de Tia Emiliana - e a morte de Maria Santa; o segundo, com a loucura do narrador-protagonista que se segue à morte dela.

De todo modo, mais do que numa "organização lógica", penso que se pode falar numa "organização pictórica" do romance. Algumas descrições são de uma plasticidade impressionante. A começar do primeiro capítulo, sempre muitíssimo bem cuidado em Cornélio:

As montanhas negras, escorrendo chuva, apagadas pelo denso nevoeiro que sobe da terra, calçada de ferro e também negra, caminham a meus olhos, lentamente, como em sonho sufocante.

\section{(...)}

Duas enfiadas de casinhas que se ajustam, comprimindo-se cada vez mais, arrimam as paredes arruinadas umas às outras, com indizível desânimo.

As janelas batem e rangem, abrindo-se e mostrando-me, a espaços, o seu interior cheio de miséria e de sombras fugidias. Tudo se confunde com o céu muito baixo, que parece todo ele, também, de lama negra desfazendo-se na enxurrada, que corre por toda a parte. Vultos sombrios se aproximam, vêm ao meu encontro, e o animal aperta os passos incertos, ferido pelo chicote. (Fronteira, cap. I, p. 21-2)

Sobretudo as descrições das ruas e do casario em dias de chuva são particularmente sugestivas: 
Casas berrantes de oca, ao lado de paredes alvíssimas, cegas de luz, trepavam em desordem pela rua em forte ladeira, ao encontro do edifício da cadeia, muito grande, empapaçado lá no alto, todo cheio de sinais misteriosos, traçados em suas velhas paredes pelas crianças, pelo tempo e pela umidade.

Parecia o crânio apodrecido de uma caveira ali enterrada há muitos anos, acocorada, à moda dos índios, no cimo do morro, e que as chuvas e enxurradas fossem descobrindo lentamente.

(...)

Quando chovia, as águas formavam logo um riacho, que corria pela sua base, formada de pedras irregulares, como grandes dentes maltratados, quase desprendendo-se do gigantesco maxilar... (Fronteira, cap. XVIII, p. 45)

Ou então:

As chuvas começaram a cair, insistentes, intermináveis, isolando, com suas imensas e espessas cortinas, primeiro a cidade, os caminhos perdidos na lama, onde se enterravam os carros e as tropas, as barreiras da estrada de ferro mais próxima, que escorriam pesadamente dos morros e sepultavam os trilhos sob grandes massas moles, que a tudo se agarravam e penetravam em toda a parte, depois a casa, transformada a rua fronteira em um rio de águas negras e rápidas, e a parte baixa dos fundos em um enorme lago de águas frementes, tamboriladas constantemente pelas gotas que caíam sem cessar, e faziam, nos telhados, um ruído de punhados de moedas, atiradas por antigos demônios.

As folhas, nas árvores, murmuravam dia e noite, e as pedras gemiam, como o eco de uma inumerável e sombria multidão que cerrasse fileiras em torno de nós, em um cerco tenaz e fantasmagórico. As sombras apenas empalideciam com a luz dos dias que passavam, e toda a cidade se perfilava confusamente nas nuvens baixas que a envolviam, vagamente ameaçadoras.

(Fronteira, cap. LVI, p. 120)

Por meio ora da personificação, ora da metáfora ou da comparação, os elementos da natureza ganham formas de entidades sombrias e espectrais, dotadas de movimentos próprios do homem ou de fantasmas. As águas negras, a lama e as nuvens baixas tornam tudo indistinto, pegajoso, misturado, dissolvente. Uma paisagem sobrenatural parece formar-se sem perder a sua "concretude". Essencialmente pictórico é também o 
contraste entre o claro e o escuro, entre luz e sombra, presente no final do último fragmento transcrito e que aparece um sem-número de vezes ao longo da narrativa.

Além disso, o pintor tornado escritor parece trabalhar com alguns motivos que se espalham pelo livro como num quadro. Esses motivos, por sua vez, relacionam-se uns com os outros por meio de analogias ou por contrastes. Um deles, e dos mais freqüentes, é a representação e o artifício e tudo que se refere a teatro, encenação, desempenho de um papel, movimentos e gestos estudados e convencionais, cálculo, mentira, máscara ${ }^{32}$. Ocorrem também, embora não sejam tão freqüentes, menções à literatura e a histórias e narrativas orais, à pintura, ao desenho, a telas e quadros, bem como à estatuária e a imagens de santos.

Há assim um constante diálogo metalingüístico com a própria criação artística. À ironia do epílogo, já mencionada, sobre a "estricta observação de factos reais" corresponde a descrição do quadro que representava a avó de Maria Santa no capítulo XVI, pintado com "ingênua exatidão". As imagens de Tia Emiliana, com seus olhos "exageradamente patéticos", suas lágrimas de parafina, suas faces manchadas de vermelhão, seus cabelos "verdadeiros", são descritas por sua vez como de um "ingênuo e esquisito artifício". Mas, como também foi dito, é por meio delas que o narrador busca retomar a humanidade perdida. Ainda mais grosseira que essas imagens é a caixa com bichinhos espetados, e nem assim deixa de ser, como vimos, uma obra de arte. A luz nova, que possibilitaria o cessar do mistério e do terror infantil, ao acabarem com as trevas e com a luz vacilante dos lampiões, só fazem com que as salas, "violentamente iluminadas", pareçam a ele "ainda mais misteriosas e aterrorizantes". A todo momento no romance subvertem-se as relações esperadas entre causa e efeito; as imagens, com suas analogias e contrastes, superam a todo instante as explicações lógicas e "sensatas". É assim que outros motivos surgem quase como leitmotivs: o estranhamento de si mesmo $^{33}$ e do outro, a animação da natureza e do inanimado, o mobiliário antigo e

\footnotetext{
${ }^{32}$ Isto pode ser visto no romance em relação a praticamente todos os personagens e talvez com maior freqüência e certamente de modo mais contundente quando referidos a Tia Emiliana: "Como se estivesse a calcular meticulosamente os seus gestos, ritmando-os e regularizando-os com minúcias, segurou respeitosamente as mãos de Maria Santa, que tinham sido piedosamente postas em cruz, e beijou-as com lentidão num cerimonial solene e bizarro." (p. 154)

${ }^{33} \mathrm{O}$ melhor exemplo é dado logo no início do livro, quando o personagem, tendo acabado de adentrar o quarto, depois de chegar de viagem, ao lavar as mãos na água fria de um jarro, ergue a cabeça e não contém um "movimento de recuo medroso", pois vê que alguém o observa e cujo olhar encontra o seu. Depois de ver a "face manchada e lívida", retorna e fita "com esforço aquele vulto, e ele surge, lentamente, de entre as manchas, e forma-se, toma corpo, vindo parar diante de mim”. É só então que o personagem se reconhece, "por entre o mareado do espelho, com o busco inclinado para a frente, com os braços apoiados fortemente, na pedra de espaldar”. (p. 23) Em 1919, Freud publicara um ensaio a que já
} 
desmesurado, os crimes terríveis e nunca aclarados, a dor e o sofrimento lancinantes e muitas vezes sem causa aparente, a imagem da ave ou do pássaro noturno, as menções a bruxas, feiticeiras e fadas, o jardim desolado.

Esse tipo de composição que privilegia a associação e a analogia em detrimento da lógica, e que, em lugar de se valer do mistério como estratégia para despertar a curiosidade do leitor até que ao final tudo se esclareça, deixa que o romance termine com quase tudo mergulhado na sombra e no desconhecido, esse tipo de composição, como qualquer outro, não deve ser imotivado, mesmo sabendo-se que em relação à criação artística muito restará inexplicado. É claro que se pode buscar parte da explicação no Catolicismo do autor, e Fausto Cunha mesmo, apesar da afirmação de que não conhecia o escritor e nada sabia de suas crenças, chegou a desconfiar que Cornélio Penna estivesse às voltas com questões escolásticas e de "ordem teológica"34. Independentemente disso, haverá outras motivações que se somem a essa. É muito provável que o fato de ter sido pintor tenha tido um papel muito importante nessas escolhas. É também bastante pertinente acreditar que residiria aí não somente uma crença religiosa, como uma visão filosófica de mundo que reconhece a impossibilidade do conhecimento de muito do que nos cerca, a consciência do que há de misterioso e insondável na natureza e no próprio homem. Esse modo de ver as coisas já encontraria ressonâncias em inúmeros artistas, filósofos e cientistas do final do século XIX e começo do XX. Mas o que pretendo mostrar aqui é que Cornélio Penna, como artista que era, pintor e romancista, "antena da raça" na expressão poundiana, deu expressão a um sentimento não apenas individual, mas coletivo, de não-pertencimento, de exílio, de inadaptação a um mundo que se pretendia moderno e em processo de modernização, que não só carregava um lastro secular e inamovível de atraso e barbárie como não queria aceitar que muito desse moderno e dessa modernização era em si mesmo bárbaro e atrasado ${ }^{35}$. Assim, se é lícito pensar na psicologia individual em busca das possíveis relações do psiquismo com esse sentimento, pode-se igualmente indagar sobre o contexto histórico em que ele surge.

fiz menção, "O estranho", em que descreve uma situação vivenciada por ele muito parecida com a descrita por Cornélio. Não importa tanto saber se Cornélio teria tido acesso a esse estudo como pensar nas conclusões a que Freud foi levado por esse episódio: "O estranho é aquela categoria do assustador que remete ao que é conhecido, de velho, e há muito familiar." (Obras completas, vol.XVII, p. 277)

${ }^{34}$ Op. cit., p. 127.

${ }^{35}$ V. nota 23 do primeiro capítulo. 
Um ano depois do lançamento de Fronteira, é publicado um livro de interpretação do Brasil que se tornaria, nas palavras de Antonio Candido, "um clássico de nascença": Raízes do Brasil. Nas suas primeiras e impactantes linhas, num estilo literário primoroso, o autor afirmava: "Trazendo de países distantes nossas formas de convívio, nossas instituições, nossas idéias, e timbrando em manter tudo isso em ambiente muitas vezes desfavorável e hostil, somos ainda hoje uns desterrados em nossa terra." (p. 3, grifo meu) Embora não se pretenda aqui em absoluto estabelecer qualquer associação entre o historiador e o romancista, talvez valha a pena transcrever uma fala do narrador-personagem dirigida ao misterioso personagem vestido de preto na ocasião de um passeio pelos arredores da cidade:

- Tenho inveja dos índios - prossegui - que neste mesmo lugar olharam sem espanto para tudo isto... Eles eram a parte melhor deste todo, e a sua moralidade era uma só, em um grande ritmo e uma grande marcha que destruímos e quebramos pela morte, e pela luxúria, ao passo que, para mim, todo este monstruoso panorama representa apenas um motivo estrangeiro e hostil, que me assusta, que me dá medo pelos seus excessos e pela sua morte mágica.

"Não quero ver mais; sinto-me enlouquecer, ao me lembrar [...]

(Fronteira, cap. XLIX, p. 107)

À harmonia entre o índios ${ }^{36}$ e a paisagem montanhosa sucede a desarmonia entre o homem "civilizado" e esse mesmo meio; à integridade moral daqueles, a consciência dividida deste último. Tudo então torna-se estranho para ele, tudo é estrangeiro. $\mathrm{O}$ desconhecimento não é apenas o reconhecimento dos limites do conhecimento humano, mas a constatação de que há um intervalo historicamente determinado entre o homem e as coisas que o cercam. Qualquer avanço na direção da civilização significa um aumento desse intervalo, dessa distância ${ }^{37}$. Mais decisivo que esses avanços para a agudização do sentimento de exílio parece ser a mistura entre avanços e recuos, a permanência do que é próprio de um mundo antigo num mundo que se moderniza: o lampião e a luz elétrica, os mortos enterrados nas igrejas e as novas leis de enterramento, as vilas afastadas e os grandes centros urbanos, a crença no poder das

\footnotetext{
${ }^{36}$ V. nota 17 - cap. 4.

37 "O mito converte-se em esclarecimento, e a natureza em mera objetividade. O preço que os homens pagam pelo aumento de seu poder é a alienação daquilo sobre o que exercem o poder." (Max Horkheimer e Theodor W. Adorno, Dialética do Esclarecimento: fragmentos filosóficos, p. 24.)
} 
relíquias e a curiosidade fria dos que não mais crêem, a expectativa dos milagres e o fracasso de sua realização, a magia e a religião.

Creio, porém, que não é possível ver nesses pares a positividade de uns e a negatividade de outros, ou mesmo vê-los como polaridades antitéticas muito bem marcadas e definidas. Ademais, embora a loucura pareça na realidade advir muitas vezes da recusa em se aceitar o que participa do pólo supostamente bárbaro e atrasado, costuma-se atribuí-la aos que, por qualquer motivo, mais dele se aproximam. Diz-se que ultrapassaram a fronteira da razão daqueles que insistem em permanecer na fronteira entre o moderno e o arcaico, dos que consciente ou inconscientemente acreditam na existência do que está além ou aquém da razão, dos que se recusam a olhar para as coisas apenas sob a luz chapada da lâmpada elétrica, dos que sabem que muitas coisas não se mostram nunca e que outras só se mostram, especialmente em suas irregularidades e reentrâncias, à luz bruxuleante das velas ou dos lampiões. 


\subsection{Entre o campo e a cidade}

A súbita parada de qualquer sinal de vida, em pleno crescimento e viço das plantas que formavam as muralhas da floresta, escondendo pesadamente a voz secreta de suas águas correntes e o lento mugido do gado à cata de frutas, todo o fecundo silêncio que descera sobre Rio Baixo escutava com sufocada inquietação o apito longínquo, os gritos de chamada e alarme das locomotivas da estrada de ferro que passava muito fora de seus limites.

(Dois romances de Nico Horta, p. 11)

A cidade, que o esperava lá longe, muito depois do trem resfolegante e tardo, soltando gritos de desespero nas montanhas, subindo penosamente intermináveis ladeiras, aquela cidade não era um fim, não era a meta de sua fuga...

(Dois romances de Nico Horta, p. 104)

Quatro anos separam a publicação de Dois romances de Nico Horta da estréia literária de Cornélio Penna. De imediato, nota-se a mudança do foco narrativo. De um narrador-protagonista e do artifício do diário encontrado pelo escritor-editor, o leitor se vê agora diante de um relato em terceira pessoa, naquilo que se costuma denominar narrador onisciente. Da perspectiva a posteriori em que podemos nos colocar, verificamos que esse caminho não foi mais abandonado pelo escritor nos dois romances seguintes $^{38}$. Por ser, como notou Fausto Cunha e outros estudiosos da obra corneliana, sua obra mais fraca - no que estou inteiramente de acordo -, mas não só por isso, podemos pensar Dois romances de Nico Horta como uma obra de transição, uma espécie de ensaio na utilização da narrativa em terceira pessoa, bem como no tratamento literário de alguns temas que retornariam nos demais romances. Em uma como em outro, a maturidade viria com Repouso e alcançaria a plenitude com A menina morta. Não é assim por acaso que um desses temas é a figura do negro. Embora não estivesse ausente do primeiro romance, em Nico Horta a sua dimensão e complexidade aumentam bastante, permanecendo ainda secundária para ganhar o primeiro plano apenas na última obra. Alguns temas, contudo, vão de Fronteira a Menina morta, passando por Nico Horta e Repouso, num retorno incessante, mas quase sempre com uma outra amplitude, maior ou menor, e um tratamento às vezes diverso. Se em

\footnotetext{
${ }^{38} \mathrm{O}$ mesmo talvez não possa ser dito a respeito daquele que deixou inacabado. Ao menos o segundo dos dois fragmentos incluídos nos Romances completos, da Aguilar, é narrado em primeira-pessoa.
} 
Fronteira, a despeito da presença de alguns personagens secundários, a narrativa estava toda ela centrada praticamente nos três principais personagens, e especialmente no par Maria Santa / narrador do romance, quase nunca saindo desse círculo estreito, em Nico Horta esse quadro se amplia. Primeiro, se pensarmos em Nico como o personagem correspondente ao narrador-protagonista de Fronteira, a sua relação com Maria Santa se desdobra no segundo romance em Maria Vitória e Rosa. Depois, o personagem ganha um irmão gêmeo, e a história da mãe é contada desde seu primeiro casamento, passando pelo segundo e pela concepção dos gêmeos. Durante o relato dessa história, dada em muitos momentos pelas recordações do personagem, conhecemos um pouco da família de Dona Ana e de cada um dos dois maridos; trata-se quase de um "romance" à parte e, parece-me, superior em muitos aspectos ao "outro romance",39. Por fim, há uma ampliação espacial em relação a Fronteira, em que a ambientação é restrita quase tãosomente à casa de Maria Santa. Em Dois romances de Nico Horta, não apenas o protagonista se desloca constantemente de sua casa na cidade para o trabalho diário com o Sr. Andrade (é assim que acabamos conhecendo também a sua família), como ele e outros personagens se deslocam do campo - a fazenda do Rio Baixo - para a cidade, da cidade para o campo, e novamente de volta à cidade - uma Itabira não-nomeada no interior do romance, mas somente na dedicatória do escritor. É num desses deslocamentos que se dá o episódio narrado a partir do capítulo XLVIII, cujo início a seguir se transcreve:

Espreitaram primeiro no rebordo do morro, que se recortava pesadamente no céu cinzento. Agitaram-se como braços aflitos, ansiosos pela sua chegada, e quando Nico Horta dobrou enfim a estrada, avistando o outro lado, as três palmeiras imperiais, que tinham crescido naquele pequeno alto, por um milagre, se perfilavam graves e ingênuas na sua majestade, formando um pórtico de suntuosa beleza, em estranho contraste com a fazenda. Era esta constituída por uma longa casa esmagada pelo telhado enorme, com janelas muito altas, decapitadas pelo beiral bojudo e cheio de limo, parecendo as telhas que o formavam gordas folhas de inhame. A varanda de onde partia a larga escadaria de entrada era grande e coberta, tendo dois grandes bancos de cada lado.

Tudo estava em silêncio, e o tropel do cavalo de Nico ressoava na terra dura, dela tirando sons de tambor em funeral, sem que um rosto curioso, um cão

\footnotetext{
39 "Os capítulos iniciais deste romance novo, em que se relata a história de D. Ana, são simplesmente magistrais". (Mário de Andrade, "Romances de um antiquário", O empalhador de passarinho, p. 128.)
} 
vigilante surgisse ao seu encontro. Só depois de ter apeado, depois de ter prendido as rédeas no moirão, e subido alguns degraus gritando: “Ó de casa!” é que surgiu diante dele um velho, de chapéu na cabeça e sapatos novos, de um amarelo muito alegre. Batia as pálpebras, como se acordasse naquele momento, mas sentia-se no seu vestuário o preparo, qualquer coisa que mostrava ter estado à espera do visitante.

- Chegue, meu parente, e venha tomar café...

Nico há muitos anos não via sua prima, e sabia que ela era agora mãe de muitas moças. Estariam elas em casa? Nada fazia prever a presença de criaturas humanas naquele escuro e baixo corredor que se abria diante dele, com uma grossa grade de madeira ao fundo, entre cujos varões se percebia uma luz vaga, da tarde, vinda naturalmente das janelas da sala assim fechada.

O fazendeiro sentara-se no banco no alpendre, e, tendo tirado do bolso fumo e palha, entregava-se, inteiramente absorto, à difícil e grave feitura de um cigarro sertanejo. Nico Horta, que sentia pelo corpo todo o cansaço da viagem, tentava em vão lembrar-se de alguma coisa que pudesse dizer-lhe, que pudesse interessá-lo, e fizesse, ao mesmo tempo, com que ele próprio esquecesse as reflexões que lhe vinham ainda em grupos vagos e discordantes à mente. Mas o silêncio se prolongava, e a posição incômoda que escolhera fazia com que tivesse a impressão de que duas pessoas se tinham apoiado, muito pesadas, aos seus ombros. Com o crepúsculo, a figura daquele homem se esbatia pouco a pouco, perdendo os contornos, e os seus gestos, muito medidos e curtos, aumentavam ainda mais a irrealidade crescente. Nico sentia com esquisita angústia as sombras a cercarem de todos os lados, naquele alto onde se achava, e pensava com medo no momento em que se perderia nas trevas, tendo apenas diante de si aquela outra sombra, mais escuro do que as outras, porque guardava em si uma vida.

Todos os ruídos tinham cessado lentamente em torno deles, e um silêncio espesso, solene, ergueu-se do solo, perdendo-se no céu negro e pesado.

(Dois romances de Nico Horta, cap. XLVIII, p. 106-7)

O estranhamento provocado por um capítulo que se inicia dessa forma não advém unicamente da personificação das palmeiras, mas dá-se sobretudo em função da construção sintática das duas frases iniciais. A primeira é uma frase curta e de sujeito elíptico, iniciada pelo verbo "espreitar" conjugado na terceira pessoa do plural. A segunda apresenta uma primeira oração que tem certo paralelismo com aquela, agora com o verbo "agitar-se" em seu início e com idêntica conjugação. Se o verbo da 
primeira frase sugeria uma ação própria de seres humanos, este outro confirma a sugestão ao mesmo tempo em que a torna problemática por meio da comparação. Dizer como implica uma distância necessária entre os dois elementos que se pretendem comparáveis. É só com a segunda oração - coordenada àquela primeira e precedida por uma subordinada adverbial, tendo ainda uma outra adjetiva intercalada - que o sujeito nos é revelado: as três palmeiras imperiais, que "se perfilaram graves e ingênuas na sua majestade", descritas ainda aqui com a utilização de verbo e epítetos peculiares ao homem. Há ainda um contraste entre a primeira comparação com "braços aflitos, ansiosos pela sua chegada" e a alusão metafórica posterior à gravidade e ingenuidade dessas palmeiras.

De todo modo, o maior contraste, e explicitado como tal, é aquele apresentado entre as palmeiras imperiais, que formavam "um pórtico de suntuosa beleza", e a fazenda e a casa, "esmagada pelo telhado enorme, com janelas muito altas, decapitadas pelo beiral bojudo e cheio de limo". Os qualificativos enorme e altas, que poderiam encontrar alguma correspondência na altura das palmeiras imperiais, crescidas "no rebordo do morro", parecem apenas tornar a imagem da casa mais pesadamente plantada no chão ao serem contrastados pelos adjetivos esmagada e decapitadas. De traços largos e esparsos, em toda a sua plasticidade, a casa surge assim como que afundada na terra sob o peso descomunal e desproporcional do telhado e do beiral atrás das palmeiras que tocam o céu.

O uso de decapitadas ressoa ainda no tropel do cavalo que tirava da terra dura "sons de tambor em funeral". E são essas alusões fúnebres que criam a ambiência em que vai se dar a passagem de Nico Horta pela casa dos parentes, em busca de pouso para continuar no dia seguinte a viagem da fazenda do Rio Baixo em direção à cidade devido ao longo percurso. Não saberemos quase nada dessa família a não ser que se tratava de uma prima de Nico Horta e que ela teria muitas filhas. Nem mãe nem filhas aparecem durante a estada dele na fazenda. Apenas o marido, que o chama "meu parente", o recebe, e depois um rapaz, provavelmente filho dele, recebe a ordem de levá-lo a seu quarto. No capítulo L, sugere-se que as moças deviam estar em casa, pois Nico podia ouvir, já montado para a partida, outra música, diferente da que ouvira na longa noite passada sob aquele teto, a dos grilos e das rãs, "risos jovens, um pouco discordantes e nervosos, que se erguiam alternados, num ritmo esquisito". Sugerem-se aqui - pois não há quase nada que não seja apenas sugerido - os receios, a desconfiança, o medo, por parte dessa família sertaneja, de receber um moço, ainda que parente, e deixá-lo em 
contato com as filhas, ainda que por pouco tempo. O isolamento, a incomunicabilidade, o fechamento ao outro não seriam nesse caso apenas uma questão restrita ao psiquismo e à interioridade dos indivíduos. Há uma verdadeira cultura da insularidade que a prática da hospitalidade mal consegue disfarçar.

Como quer que seja, é patente a incapacidade para superar esse isolamento, a despeito, pelo menos no caso de Nico Horta, do desejo de obter tal superação. Colocado diante do outro, tenta inutilmente lembrar-se de algo que poderia interessar ao fazendeiro, mas só faz crescer o incômodo de sua situação, e a impressão de ter duas pessoas "muitos pesadas" apoiadas em seus ombros e, depois, a materialização do próprio silêncio, “espesso, solene, [...] perdendo-se no céu negro e pesado", podem levar-nos a associar a imagem do personagem vergado sob esse peso tremendo à da casa descrita no início desse capítulo. Há assim, como em Fronteira, um jogo de projeções do interno sobre o externo e vice-versa. As tentativas de comunicação como que esbarram nas paredes robustas, posto que invisíveis, erguidas entre os homens ${ }^{40}$. Deitado depois na mesma cama que o filho do fazendeiro ${ }^{41}$, junto mesmo de seu corpo, indaga-se "como pudera aceitar deitar-se ali, ao lado daquela criatura cujo rosto nem sequer vislumbrava, cujos pensamentos lhe eram completamente estrangeiros, absolutamente fora de seu alcance?" (p. 110) O sentimento de alteridade torna-se mais agudo na medida em que projeta no outro, por inversão, a ausência de conflitos e especialmente daqueles que fazem com que o sujeito se sinta dividido, daqueles que seriam responsáveis por suas fraturas, por seu sentimento de incompletude:

"Ele dorme, - pensou Nico - dorme, sem sonhos, sem angústia, como um prêmio forte e sadio de seu trabalho no eito. Cheio ainda de sol dos campos, sacudido pelo andar balanceado de seu cavalo, tendo a certeza do que faz e do que diz, ele repousa, ele REPOUSA", repetiu alto. Mas, assustado, esperou que dissessem algumas palavras e ficou à escuta, na sombra, sem ver o seu companheiro. Nem um sopro lhe veio ao rosto, que, entretanto, devia estar perto da cabeça do outro, pois sentia agora o cheiro quente de seus cabelos, e Nico pensou que devia ser assim o do pêlo das onças da mata, cujas árvores avançavam até perto do muro arruinado das cocheiras. E muito tempo esteve com o ouvido fito...

\footnotetext{
${ }^{40}$ No terceiro capítulo, o narrador alude a "pesados muros transparentes" que se erguiam entre D. Ana e seu pai e através dos quais ele olhava a filha.

41 É este mais um elemento de estranhamento, pois o fazendeiro não parece dar a Nico nenhuma explicação disso e muito menos pede desculpas por tão mal acomodá-lo. Ele só se dá conta de que é ali que devia se deitar por não divisar outra cama no quarto para onde fora levado pelo rapaz.
} 
O que Nico inveja no outro é a vida mais simples e regular, o trabalho rude e braçal na lavoura, a maior proximidade que parece ter em relação à natureza. $\mathrm{O}$ repouso não é apenas aquele obtido pelo cessar da vigília, o sono profundo após um dia de extenuante trabalho, mas a cessação dos intermináveis pensamentos, reflexões e embates na consciência do indivíduo. A entrega ao trabalho simples no campo seria o melhor antídoto contra a inquietação e a angústia geradas pelo pensamento que não alcança deixar de pensar-se a si próprio, que não alcança o desejado descanso, sobretudo por aquele que conheceu a cidade e nela viveu a maior parte da vida ${ }^{42}$.

Além de sua situação cronológica no interior da obra de Cornélio Penna, Dois romances de Nico Horta de algum modo explicita a sua posição medial ao praticamente antecipar o título do romance que só seria publicado em 1948, como podemos ver no uso da palavra "repousa" em caixa-alta no fragmento citado, depois de ter sido ele mesmo "anunciado" em Fronteira, numa das frases enigmáticas do narrador:

Mas alguma coisa existia sempre em minha vida, e a figura contraditória de Nico Horta vivia, latente, ao meu lado, ocultava-se em meandros de minha memória, cercava-me e confundia-me disfarçada em idéia de morte, de suicídio, ou em pressentimentos vagos e misteriosos. (Fronteira, p. 47)

Mais importante que isso é o fato, já mencionado, de Cornélio, em Nico Horta, por assim dizer ensaiar a narração em terceira pessoa que irá utilizar nos dois romances seguintes. Ocorre que essa utilização será ofuscada por uma excessiva proximidade do narrador com o personagem principal, algumas vezes praticamente confundindo-se com ele, o que fará com que a maior parte da narrativa seja dada do ponto de vista de Nico

\footnotetext{
42 "Com efeito, a habitação em cidades é essencialmente antinatural, associa-se a manifestações do espírito e da vontade, na medida em que se opõem à natureza. Para muitas nações conquistadoras, a construção de cidades foi o mais decisivo instrumento de dominação que conheceram. Max Weber mostra admiravelmente como a fundação de cidades representou para o Oriente Próximo e particularmente para o mundo helenístico e para a Roma imperial, o meio específico de criação de órgãos locais de poder, acrescentando que o mesmo fenômeno se encontra na China, onde, ainda durante o século passado, a subjugação das tribos Miaotse pôde ser identificada à urbanização de suas terras. E não foi sem boas razões que esses povos usaram de semelhante recurso, pois a experiência tem demonstrado que ele é, entre todos, o mais duradouro e eficiente. As fronteiras econômicas estabelecidas no tempo e no espaço pelas fundações de cidade no Império Romano tornaram-se também as fronteiras do mundo que mais tarde ostentaria a herança da cultura clássica. Os domínios rurais ganhavam tanto mais em importância, quanto mais livres se achasse da influência das fundações de centros urbanos, ou seja quanto mais distassem das fronteiras." (Sérgio Buarque de Holanda, Raízes do Brasil, p. 61-2)
} 
Horta, excetuando-se obviamente os capítulos iniciais, dedicados à história de sua mãe. De modo algo paradoxal, há nesse romance narrado em terceira pessoa mais talvez da interioridade do protagonista do que em Fronteira, narrado em primeira pessoa. Isso por si só não se configuraria como um defeito; é aliás desse paradoxo e dessa "limitação" que algumas obras-primas publicadas igualmente na primeira metade do século $\mathrm{XX}$ tiram sua grandeza e originalidade. Parece ser na insegurança desse uso em Nico Horta que reside o problema. Há um certo descompasso entre o que pode ser visto como uma primeira parte do livro, dedicada a Dona Ana, e a segunda, a Nico. No interior mesmo desta última "parte", o narrador às vezes se aproxima da interioridade de Pedro como o faz com o irmão, mas aquele acaba, sem mais nem menos, "sumindo" da história, o que foi muito lamentado por Mário de Andrade, que via na figura do duplo e nas tensões e conflitos que dela poderiam advir o maior potencial do romance. Por outro lado, parece ser o descritivo, mesmo que mediado sempre pela interioridade que se projeta nas coisas, um pouco menos freqüente no segundo que no primeiro dos romances cornelianos. O equilíbrio só será alcançado em A menina morta, mas os ganhos desse “ensaio" em Dois romances de Nico Horta poderão ser entrevistos em Repouso.

À observação perspicaz de Luiz Costa Lima de que há um recuo gradativo no tempo ao se acompanhar a obra de Cornélio Penna no sentido cronológico de sua publicação, pode-se talvez acrescentar a percepção de que há igualmente nesse vetor uma riqueza cada vez maior da realidade exterior em meio à onipresença da realidade interna. Isso não é tão significativo ou visível em Dois romances de Nico Horta por se tratar da primeira tentativa de narração em terceira pessoa por Cornélio, mas, ainda que não se reconheça nele uma maior freqüência de descrições exteriores, deve-se convir que o quadro composto pelos principais personagens, como foi visto, é mais amplo do que em Fronteira. $\mathrm{O}$ exemplo mais evidente dessa realidade, que se mostra a despeito do ensimesmado dos personagens ou por causa mesmo desse ensimesmamento, é a presença dos negros, como que prenunciando o relevo que teriam em A menina morta, como já foi notado. No capítulo LV, Nico Horta revira o "quarto dos badulaques" onde encontra diversos objetos estranhos, dentre eles "três medonhas gravatas", com laço feito e embrulhadas em papel de seda, e de modo ainda mais estranho com algumas palavras e as suas iniciais no invólucro, feitas com sua própria letra sem que conseguisse lembrar-se de tê-lo escrito. Ao olhar bem para as gravatas, percebe manchas cor de ferrugem que "pareciam de sangue..." e maquinalmente fixa nelas os olhos. Então, essas manchas trazem de volta todo um passado esquecido: 
E logo uma voz rouca e alquebrada, mas tão querida, tão suave como a mais linda das músicas, soou aos seus ouvidos.

- Eu me feri e manchei esta com o meu sangue - dizia a voz - e o nenen a guardará para sempre, como lembrança da velha, não é?

Quantas recordações, revoantes, bateram de chofre em seu coração, tentando sufocá-lo, e fazendo com que uma onda amarga subisse à sua garganta e aos seus olhos! Em torno dele, como chamas que se ateassem e se erguessem, apressadas, devoradas, surgiu, forte e intacto, invasor e infinito, o amor escravo de sua mamãe negra, incompreendida e desprezada, mas não vendo nem querendo ver o mal em seu despótico e pequeno senhor. (Dois romances de Nico Horta; p. 126)

Quase nada é narrado de maneira objetiva, mas tal como as recordações teriam se apresentado então ao sujeito, fragmentadas, incompletas, com uma hierarquia própria e alheia à lógica e à razão usuais. Contudo, Cornélio Penna obtém algumas cenas mais fortes talvez do que se intentasse a "reprodução fiel e fidedigna da realidade". O menino genioso e violento, com a curiosidade por saber o motivo das exclamações constantes da negra, "que pena! que pena!", ao ver que ela se negava a responder, mesmo diante das interrogações repetidas e dos gritos, "dera-lhe com os pés um golpe seco em pleno peito caído e mole; diga: digaaaa...!" A antiga escrava, a mamãe negra, diante da violência sofrida então "respondera, sufocada por um soluço guardado, com os olhos obstinadamente baixos, para não correrem as lágrimas: por isso mesmo, por isso mesmo, nenen..."

O drama terrível da escravidão surge assim com uma força talvez impensável num escritor dito "intimista". É possível entrever nessa pequena cena rememorada pelo protagonista a mistura na escrava entre a ternura pelo menino que criava como um filho e a dor e o sofrimento provocados por ele e cuja expressão devia ser contida a todo custo, a mescla de amor materno e auto-compaixão, de afeto e medo e terror pânicos, de cuidados e vingança, a ambivalência de sua situação de mãe-negra e escrava, de doadora da vida e propriedade daqueles a quem a doava, de proximidade máxima e distância abissal. Do ponto de vista do menino branco e livre, filho de antigos proprietários de escravos, a mistura e a ambivalência de sentimentos não seriam menores: a incompreensão, o afeto, o desprezo, a violência, a piedade, a vingança, o arrependimento. Mais do que uma tristeza congênita provocada pela fatalidade do 
isolamento humano, Cornélio Penna parece sondar, em momentos como esse, em que medida a solidão do sujeito, o seu sentimento de incompletude e de carência teriam resposta nas circunstâncias de seu crescimento e desenvolvimento, isto é, em que ponto o psicológico encontraria o histórico.

Mais do que simplesmente observar o predomínio do duplo em Dois romances de Nico Horta - a mãe negra e a mãe branca, os dois maridos, os irmãos gêmeos, as duas mulheres -, é preciso refletir sobre a sua motivação. Desde Fronteira, colocava já Cornélio a questão da convivência, num mesmo espaço e muitas vezes no interior de um único ser, de dois mundos, diametralmente opostos, porém ligados de modo inextricável, fruto de toda divisão, de toda angústia, de toda loucura. Essa duplicidade fundamental parece materializar-se no segundo romance na figura do duplo. Talvez por isso não tenha Cornélio insistido muito no contraponto entre os irmãos, como Mário de Andrade queria. Dos duplos presentes no romance, ele é o mais claramente delimitado, pelo menos até determinado ponto do romance. A partir do momento em que Nico se junta a Pedro na fazenda do Rio Baixo, as coisas de complicam. Dos outros duplos, pode-se dizer que são, por sua vez, complicados de partida. Essa duplicidade é figurada pelo deslocamento entre a fazenda e a cidade, e tornada mais complexa pelas menções à capital e ao trem de ferro e às locomotivas. Praticamente tudo isso é já anunciado no primeiro capítulo do romance, em meio à referência explícita a um "outro mundo":

todo o fecundo silêncio que descera sobre Rio Baixo escutava com sufocada inquietação o apito longínquo, os gritos de chamada e alarme das locomotivas da estrada de ferro que passava muito fora de seus limites. Era um outro mundo que ameaçava de longe, ... (p. 11)

Trata-se então de dona Ana, que, deitada, sente-se tomada pelos fantasmas do passado:

Em torno, como cenários que se levantam, tremendo, e se fixam em equilíbrio instável, desenha-se toda negra uma fazenda de mineração de ferro, perdida na grande mata sombria, com a sua forja, ferida rubra, arfante, vibrando, latejando, aos golpes agudos dos martelos.

"Na soleira da porta está a criatura que se alonga pelo tempo, olhando, olhando.

"Na sua frente, do outro lado do terreiro negro de borra de ferro, andando para cá e para lá, entre centelhas e chamas que se lançam para o alto e fogem, entre as 
bigornas gritantes, está o vulto de seu pai, aquele de quem ela tem medo... apesar de nunca ele lhe ter batido. (p.13)

Depois do pai, relembrado em meio a esse cenário carregado de cores e sons muito vivos, intensos, vibrantes, surgem em sua memória a figura dos irmãos, que, ao contrário dele, a espancavam com freqüência, e a imagem da mãe, resignada e covarde, incapaz de protegê-la contra os filhos, que acabavam premiados com seus excessivos afagos. A lembrança dos irmãos e da mãe remete à imagem do amigo deles, Nico, seu futuro marido, que um dia chegara a cavalo com eles e, ao apear, estendera as rédeas à mãe, que as recebera de modo servil. A livre associação, única "lógica" a que a memória se dobra, a leva ao momento em que se dirigiu ao pai, durante o trabalho na forja - chegando a lembrar a figura de Hefésto -, quando ele examinava grandes esporas de ferro, para lhe comunicar a decisão de se casar com Nico. Não obtém dele resposta alguma, nem divisa qualquer manifestação de agrado ou desagrado, nem antes nem depois, e ao concretizar-se o casamento recebe a ordem de nunca trazer o marido à fazenda enquanto o pai for vivo. Do casamento, restaram as lembranças das noites de amor, de "rendição noturna", o sentimento duplo de vaidade e de culpa, e com os anos a espera do marido em suas inexplicáveis viagens, "das quais retornava embriagado e quase sempre ferido", até a sua morte na própria cama do casal: "Estava só e livre." Mas não se passou muito tempo até que sentisse ser demasiada a liberdade e a associasse ao sentimento de abandono. Então, no meio dessas lembranças todas, Dona Ana volta a si e compreendemos que seu repouso é motivado pelo estado de gravidez:

"É necessário que ele nasça," pensou, e sentiu-o mover-se, imperceptivelmente, como se já orientasse os seus passos para o mundo. $\mathrm{O}$ ventre enorme, coberto com a colcha branca, pareceu-lhe surgir da penumbra, no meio do leito, como uma montanha de neve, de países distantes, estranho ao seu corpo magro, e masculino. (p. 23)

Quando do nascimento, descobre que o que ela pensava fosse "ele" eram na verdade dois meninos. Ao ser indagada dos nomes, diz que um se chamaria Pedro. Perguntada sobre o outro, responde Antônio, e num ato falho acrescenta: "é o nome do pai”. Dando-se conta do engano, ela se benze e afirma: "É Pedro! Meu Deus... é Pedro! É Pedro que é o nome do pai... Antônio é o nome do outro...!" Mas o segundo filho 
acaba ficando mesmo com "o nome do outro" e, como o marido anterior de Dona Ana era conhecido por Nico, recebendo igual apelido. Para que não se confundisse com aquele, era chamado Nico Horta. Assim, desde o nascimento, recai sobre o ele o estigma do estranho, do diferente, do enteado sem que propriamente o fosse, e em tudo diferente do irmão. Acaba desse modo sendo vítima da hostilidade do próprio pai e, o que é pior, passa a tentar compreender e a explicar a si mesmo as razões desse modo hostil de ser tratado, desenvolvendo pelo pai uma admiração sem limites e um sentimento de inferioridade e de humilde gratidão pelas menores demonstrações de afeto que dele recebia.

Após a morte do pai, de quem nada parecia ter ficado na memória de Nico, a família muda-se para a cidade e com eles passa a morar Maria Vitória, a respeito de quem quase nada se esclarece. Teria vindo da mesma fazenda onde o pai dos gêmeos nascera (sugestão de ser sua filha natural e portanto meia-irmã de Nico e de Pedro?), e de algum modo Maria Vitória o substituíra naquela "afinidade escondida" que Nico sentia existir entre ele e o pai, a despeito da hostilidade, e que era o contraponto necessário à presença forte e autoritária da mãe. Pedro, por seu turno, retorna ao Rio Baixo e passa a administrar a propriedade da família. Algum tempo depois, Dona Ana decide que todos deviam voltar ao Rio Baixo, mas é Nico Horta quem primeiramente se desloca para lá. E aqui, ou muito me engano, ou começam algumas das incongruências do romance. Pedro, que era o exato oposto de Nico Horta desde o nascimento, torna-se muito parecido com o irmão, em suas angústias, seus medos inexplicáveis, sua melancolia, a partir do momento em que passam a conviver juntos na fazenda e em que nela chega e se instala uma misteriosa viajante. Há durante esse momento da narrativa uma ou outra sugestão de que ambos nutriam o mesmo sentimento por Maria Vitória e a disputavam entre si. Depois de Dona Ana e Maria Vitória, vemos a chegada de um médico à fazenda, o Dr. Melo, que Pedro afirma ser "médico do hospício", o que nos parece a princípio sugestão da desconfiança da mãe em relação à saúde mental de Nico Horta, para verificarmos posteriormente que seria antes Pedro o examinado. Então, não se sabe por que, é dito que Pedro iria para a capital em companhia do médico, o que acaba de fato acontecendo, e este como que desaparece da história, dando lugar a partir de então à centralidade de Nico nos episódios seguintes até o fim do romance.

Também não se explicitam os motivos de Nico para retornar à cidade, numa decisão intempestiva, deixando a mãe e Maria Vitória no Rio Baixo. Lá, recebe a visita do Sr. Andrade, um velho amigo de seu pai, e o convite para trabalhar com ele no 
tabelionato que ficava nas dependências de sua própria casa. A perspectiva de superação de seus conflitos e de seu desamparo se apresenta assim a ele, que via no "trabalho sereno" a possibilidade de adquirir finalmente o necessário "repouso". Ocorre que acaba por conhecer Rosa, de quem já ouvira D. Ana dizer ser "boa e bonita", e por aproximarse dela. Esse envolvimento o deixará uma vez mais dividido, agora entre a companhia constante da filha do sr. Andrade e as lembranças de Maria Vitória.

Boa parte da inaptidão de Nico Horta para a vida, que o levará mesmo à morte, encontra assim explicação em sua história feita da divisão. Desde o nascimento dividido com Pedro, que quase sempre levava a melhor, a começar por ter herdado o nome do pai, deixando a ele o nome do primeiro marido de D. Ana, passando pela divisão entre esta e a mãe negra, dividido depois entre a cidade e o campo, e finalmente entre Maria Vitória e Rosa, Nico Horta só podia sentir o irremediável de suas fraturas. Como em Fronteira, contudo, acena-se com a possibilidade de superação dessa divisão no encontro e na fusão com o outro, e o casamento com Maria Vitória, a despeito de aparentemente ter sido uma imposição de Dona Ana, à revelia de Nico e para sua surpresa, e apesar de sua inclinação por Rosa, parece o prenúncio de que essa possibilidade encontrara finalmente a sua realização:

Quando Nico Horta se aproximou de Maria Vitória, em seu quarto, ela compreendeu que enfim o encontrara, e todos os anos que tinham vivido lado a lado, numa triste promiscuidade de atos e gestos, caíam em pó agora por terra, afastando-se como nuvens estrangeiras tocadas por ventos repentinos.

A verdadeira comunhão surgia plena, absoluta, sem abalos, sem choques, sem surpresas, e seria eterna, perdurando acima de tudo, mesmo da separação e da ausência. Quando bem longe um do outro, aquela compreensão, que sentia ser total, ficaria sempre presente e companheira. Estariam sós pela distância e não pela incapacidade ou pela própria miséria.

Vitória ergueu-se para recebê-lo, e o seu vestido branco, caindo em grandes e rápidas dobras, tinha uma serenidade nupcial, em suas curvas sadias e fecundas.

\section{$[\ldots]$}

Era a Vida. Queria agora viver e tudo nela era apelo de renovação, de ressurreição.

(Dois romances de Nico Horta, cap. XCII, p. 208) ${ }^{43}$

\footnotetext{
${ }^{43}$ Ótima observação de Luís Bueno de que aqui o escritor faz com que a "narração [...] se desloque e seja de Maria Vitória o ponto de vista a partir do qual a cena apareça diante do leitor". (Uma história do
} 
A Vida (assim mesmo, com maiúscula) se apresenta a Nico Horta, que até então se sentia como se estivesse morto ou como se fosse um fantasma, mas logo, logo, com a morte de Rosa, essa promessa de vida se mostrará irreal e inatingível, pois Nico (o que é mais uma vez apenas sugerido) não será capaz de conviver com o sentimento de culpa pelo suicídio dela, talvez arrependido por ter se submetido tão docilmente à imposição materna. Retrospectivamente, então, essa apresentação soa quase como um escárnio. Resta indagar se era essa a intenção do escritor ou se tinha em mente a sugestão de uma outra Vida a se colocar para o sujeito depois da morte, mas é pouco provável que se possa obter uma resposta definitiva. O fato é que Nico Horta morre, depois de ser acometido por uma doença, mas, assim como a personagem que chega de viagem e se instala na fazenda Rio Baixo habitada pelos dois irmãos, a viajante, tudo o mais permanece envolto em insondável mistério.

Mais talvez do que em Fronteira, metáforas e comparações recorrentes ligam vida e teatro, o viver e a representação, a face humana e a máscara:

Ao aproximar-se de Maria Vitória, havia qualquer coisa de miserável no seu riso tímido, e as palavras de saudação banal que trocaram não conseguiram trazer um pouco de verdade à cena que se desenrolava muito devagar, sem lógica, como se fosse representada por atores inexperientes, diante de um público severo e numeroso. (p. 73); ... e quando Nico Horta, à noite, fechava a porta de seu quarto, era como se corresse uma cortina de teatro, ... (p. 92); Eram como dois artistas que ensaiavam todas as noites, naquela mesma sala de jantar, onde o visitante agora se assentara com autoridade, chamando Nico em altos brados. (p. 135)

A superstição e as crenças populares também comparecem, embora de modo mais atenuado do que em Fronteira, na menção, por exemplo, à moeda de ouro colocada na grande bacia em que pela primeira vez foram os dois meninos lavados pela ama e “destinada a dar-lhes riqueza". Igualmente recorrentes são as alusões a autômatos e automatismos, ao sentir-se estranho e estrangeiro, ao desconhecimento e ao não reconhecimento de si e dos outros, a fantasmas e à sensação de morte em vida. Não falta mesmo referência a uma lembrança por Dona Ana dos insetos que ela espetava "com

romance de 30, p. 545.) Ao final de seu ensaio interpretativo sobre Cornélio Penna, Luís Bueno irá enfatizar o papel da mulher na obra corneliana. V. cap. 3 deste trabalho. 
grandes alfinetes". Essas recorrências todas são como leitmotivs que, por um lado, caracterizam de modo admirável a ambiência em que se movia aquela tradicional família mineira, já decadente, e, por outro, contribuem para que a atmosfera do romance se torne mais densa e opressora, podendo-se dizer talvez a ponto de em alguns momentos mimetizar o sentimento do personagem diante da vida. A impossibilidade de ser o que se é ou o que se imagina ser, a necessidade de representar o tempo todo diante dos outros, as ações que se tornam maquinais, tudo isso remete a um descompasso fundamental entre desejo e realidade, entre a intenção e a realização, entre os anseios de plenitude e a vida fragmentada. As reflexões aqui, e creio que Cornélio tem consciência disso o tempo todo, podem ser direcionadas tanto para a vida como para a arte. A busca de uma representação mais próxima da realidade ${ }^{44}$, sabendo-se de antemão do intervalo insolúvel entre ambas, passa necessariamente pelo abandono das camadas superficiais em busca de outras mais profundas:

por baixo das palavras há um outro mundo que vive, complexo e palpitante, e quando, tendo conseguido abandonar a superfície, a estrutura das frases, nele mergulhamos, com uma terrível e amarga vertigem, de perda completa e alucinante de pé, penetramos em novos e desconhecidos caminhos... e há um grande desequilíbrio para todos, talvez mais angustioso para aquele que não traz consigo a mais perigosa das armas, o conhecimento. (Dois romances de Nico Horta; p. 205)

É assim que se explica um dos sentidos do estranho título do romance, explicitado nas linhas finais: “... e o Nico Horta que ia viver um novo e diferente romance em suas memórias ali estava, como uma figura de cera, na sua límpida imobilidade.” (p. 217) As memórias da vida do personagem compõem um romance "novo e diferente" porque é impossível a exata apreensão da vida mesma e de sua complexidade. Mas a tentativa de dela se acercar tão perto quanto seja possível faz com que o escritor se afaste propositalmente da superfície dos fatos observáveis e mergulhe nos subterrâneos do personagem. O que encontra nesse mergulho não é exclusivo do íntimo desse sujeito, mas é tanto parte de sua história pessoal como, por muito ou pouco que o personagem tenha de seu criador, parte da história do escritor, sendo ainda, por extensão, parte da história do homem, em sentido mais restrito ou mais amplo.

\footnotetext{
${ }^{44}$ V. capítulo 4.
} 
No caso de Cornélio Penna, já se disse que ao longo de seus romances o escritor mantém-se sempre como o principal personagem ${ }^{45}$, onipresente e indisfarçado. As mesmas inquietações e imagens recorrentes, a menção mais ou menos velada ao romance que vem a seguir, o retorno gradativo ao passado, a ambiência na província montanhosa e depois no campo para então voltar à cidade, a presença cada vez mais acentuada do negro, a narrativa em primeira pessoa que passa depois a terceira, tudo isso que se pode observar no conjunto da obra de Cornélio Penna parece indicar uma busca mais ou menos consciente de uma representação que, ao contrário do que tem sido dito pela maior parte dos críticos, desse conta de uma realidade mais ampla que aquela que o romance dito regionalista procurava representar. Em sua recusa em aceitar a representação "realista", talvez Cornélio tenha forçado um pouco a nota em Dois romances de Nico Horta, aproximando-se em alguns momentos de uma notação que se pode chamar expressionista, como aqueles que insistem na mascarada, no automatismo, no fantasmal, noutros roçando o humor involuntário, o que de resto não se mostra incompatível de todo com o exagero expressionista, como na cena em que Nico Horta, ao sair à noite da igreja, exclama: “- Senhor [...] livrai-me de mim mesmo...” Isso tudo parece fazer as virtudes e os limites ${ }^{46}$ do segundo romance de Cornélio Penna, e resta saber em que medida esses últimos foram superados nos dois romances seguintes, quando voltaria a se colocar a dicotomia campo versus cidade ou cidade versus campo, em Repouso, para finalmente radicar o enredo de A menina morta quase inteiramente no campo, deslocando-se ainda dos cenários montanhosos de Minas Gerais para as fazendas de café do Vale do Paraíba.

\footnotetext{
45 "Na verdade, só há um vulto central - o próprio romancista." (Fausto Cunha, "Forma e criação em Cornélio Penna", p. 129).

46 É preciso, no entanto, pensar que são umas e outros que fazem a especificidade da literatura de Cornélio Penna, cabendo a lembrança da afirmação do escritor de que "a principal sepultura da arte é a perfeição". (Romances completos, p. XLVII)
} 


\subsection{Círculo mágico: encantamento e dissolução}

Mas o riacho passava ao lado do bosque, com suas águas dançantes e sonoras, cobertas constantemente por uma rede de espumas muito brancas. À sua voz, tudo se tornava vivo e animado de graça, e era bastante penetrar em sua sombra, no círculo mágico de suas árvores, para se sentir que se entrava em um pequeno mundo à parte, onde reinava o sonho. Qualquer coisa alada punha-se a bailar em rondas, com imperceptível ironia, e tudo se afastava, em uma distância e profundidade de esquecimento sobrenatural. (Repouso, cap. 36, p. 182)

Para Fausto Cunha, embora muito superior a Dois romances de Nico Horta, Repouso é ainda inferior a Fronteira ${ }^{47}$. Luiz Costa Lima, que vê no crítico o melhor analista da obra corneliana ${ }^{48}$, concorda com ele. A difícil tarefa a que me proponho aqui é mostrar por que discordo daqueles que muito provavelmente são, com Adonias Filho e Alexandre Eulálio, os principais críticos de Cornélio Penna. Para mim, se Repouso não é, como afirma Fausto Cunha, a obra de um momento genial, como o é Fronteira, é não apenas "o romancista na consciência de suas funções" como a obra em que Cornélio atinge a maturidade como escritor, o que resulta num livro que está no mesmo nível do romance de estréia, em certos aspectos, e que tem mesmo sobre ele algumas vantagens, em outros. Não significa dizer que não há problemas no livro, nem que ele representa a mais alta realização do escritor, o que para ser dito terá de esperar o momento da abordagem de A menina morta.

Duas circunstâncias me parecem ter sido fundamentais para que Cornélio Penna alcançasse essa maturidade. A primeira circunstância consiste no domínio da narração em terceira pessoa, cujo "ensaio", como vimos, teve lugar em Nico Horta. A segunda, já anunciada no primeiro capítulo, é dada pela convicção de que Cornélio Penna não só leu a crítica de Mário de Andrade como, depois de provavelmente muita reflexão, acabou por concordar com ele a respeito da maior força do mistério radicado na realidade do que aquele relativamente gratuito. Nesse sentido, é para mim impensável como uma estudiosa da obra de Cornélio Penna, depois de também expressar a "certeza" de que o autor de Fronteira teria lido essa crítica, pôde afirmar que "o fluminense não deu

\footnotetext{
47 "Forma e criação em Cornélio Penna", p. 126.

${ }^{48}$ O romance em Cornélio Penna, p. 13-4.
} 
crédito à expectativa do paulista" e que "Repouso vem a público com os mesmos efeitos/'defeitos' que desgostaram Mário, talvez até mais imperiosos do que os criticados por ele"49. A começar pelos personagens, não há em Repouso nenhum similar misterioso daquela viajante, presente nos dois primeiros romances, ou daquele homem vestido de preto em Fronteira, que não ganham esclarecimento algum até o fim dos respectivos romances. O personagem mais "estranho" é o professor, mas mesmo ele e as relações que tinha com Urbano são em geral esclarecidas. Veio à Itabira para o casamento de Dodôte e Urbano, pois este lhe enviara uma carta em que o convidava para a cerimônia, e acabou sendo chamado para padrinho. Fora seu professor numa outra cidade e acabara se tornando um amigo e guia "de muitos anos". Em vez de um mestre cheio de certezas, como se poderia esperar, o professor que chega à cidade demonstra ter tantas dúvidas quanto Urbano, mas não há nisso nada de misterioso. Logo depois do casamento, ele retorna à sua cidade, e o estranhamento que fica é apenas o dos diálogos que travara com o amigo e antigo pupilo. Mais característico, porém, de que Cornélio passa a se furtar à utilização daqueles "truques fáceis", concordemos ou não que fosse disto que se tratava, são outros episódios do romance. Sirva-nos de exemplo o capítulo 74. Dodôte está acamada em função de uma gravidez de risco depois da morte de Urbano. A avó e Chica revezam-se à sua cabeceira até que ela dá sinais de melhora, e a presença de ambas começa a tornar-se mais breve e menos freqüente. A partir de um determinado momento, só Chica vem até ela e cada vez mais raramente. Naquele estado de convalescença, Dodôte ouve um dia o bater lamentoso dos sinos e passa a ouvir vozes que cochicham, portas que se abriam e se fechavam, e o leitor é mantido em suspense a respeito da realidade ou irrealidade desses sons. Até que o narrador sugere por meio dos acontecimentos narrados que a avó de Dodôte morrera nesse meio-tempo. Tudo então se explica: o maior espaçamento das visitas ao quarto de Dodôte pela avó, por estar doente, até cessarem por completo, e por Chica, que passou a dividir seus cuidados entre as duas, bem como, de modo ainda mais significativo, os ruídos ouvidos por Dodôte, que não eram produzidos por fantasmas ou sequer pela imaginação doentia da personagem, mas, tendo origem provavelmente nas constantes entradas e saídas do médico, do padre e de outras visitas que a avó recebia em seu leito de morte, podiam ser sentidos por Dodôte daquele modo pelo simples fato de que, como o leitor, desconhecia inteiramente o que acontecia fora de seu quarto, e ainda pelo

\footnotetext{
${ }^{49}$ Letícia Malard, no prefácio à edição de Repouso da Editora Artium, p. xiii.
} 
superdimensionamento do que ouvia em função de sua saúde debilitada. Outros exemplos podem ser dados: o mover da cadeira de balanço da mãe de Urbano, já falecida, fruto da imaginação de Dodôte $^{50}$; os ruídos do abrir de portas e gavetas, ouvidos por um Urbano já muito doente, que se explicam pelos preparativos de Dodôte para sair logo de madrugada para o Jirau na companhia da avó; a "visão" do espectro de Urbano por Dodôte, em meio à tempestade e em estado febril. O que é comum a todos esses episódios não é a ausência de mistério, mas a sua radicação na realidade dos personagens, o que acaba mesmo por torná-lo mais impactante.

O estranhamento da leitura também permanece porque os personagens continuam a sentir-se estranhos e estrangeiros, incapazes de se reconhecer e de conhecer de fato o outro. E é aqui que o narrador não se limita ao estranhamento de um só personagem. Acerca-se tanto de Dodôte como de Urbano para chegar a um mesmo desamparo. Ainda no centro desse desamparo de um e de outro percebe-se a dicotomia entre cidade e campo. Se praticamente todos os acontecimentos se passam naquela, é este uma presença constante, de maneira explícita ou velada, desde o início da história propriamente dita, que se encontra no segundo capítulo, num parágrafo sobre o qual um crítico afirmou desconhecer na literatura um início de maior densidade ${ }^{51}$ :

Há muitos anos, em uma fazenda que se perdia entre grandes pedras negras e árvores hostis, que abriam os galhos famélicos, rodeada de montanhas austeras, com grandes chagas rasgadas em seus flancos possantes, de onde escorria minério podre, em ondas de lama sombria, houve um casamento triste. (Repouso, p. 36)

Trata-se do casamento dos pais de Dodôte e, como iremos descobrir, tios de Urbano. Mas o que mais nos interessa aqui é refletir sobre o poder quase encantatório dessa linguagem. A concentração é a da poesia, e os segmentos separados por vírgulas funcionam no período quase como versos em um poema. A sonoridade é caracterizada por um sem-número de aliterações e assonâncias e por diversas combinações e contrastes, por exemplo, entre encontros consonantais e vogais nasais: ... muitos anos, em uma fazenda que se perdia entre grandes pedras negras e árvores hostis, que abriam os galhos famélicos... Aqui seria preciso continuar até o final da frase, e, se

\footnotetext{
50 "Olhou de novo em torno de si, e viu que toda a fantasmagoria criada pelo seu medo caíra por terra. Tudo estava exatamente em seus lugares, e o quarto aparecia agora aos seus olhos, banhado pela forte luz meridiana, muito velhos e indiferentes. / Nada havia ali de sobrenatural." (Repouso, p. 201, grifo meu.)

${ }^{51}$ Fausto Cunha, "Forma e criação em Cornelio Penna", Situações da ficção brasileira, p. 133.
} 
fôssemos marcar cada uma das ocorrências sonoras específicas, praticamente todas as sílabas do período restariam marcadas, o que acabaria por fazer perder todo o caráter distintivo da marcação. Registrem-se então ao menos as aliterações das dentais e da velar $g$, com ou sem encontro consonantal com a vibrante $r$, como em "fazenda se perdia entre grandes pedras negras" ou em "grandes chagas rasgadas"; e também a combinação entre aliterações de bilabiais, dentais e vibrantes, como em “... possantes, de onde escorria minério podre, em ondas de lama sombria, houve um casamento triste." Das nasais, podem-se mencionar anos, fazenda, grandes, montanhas, flancos, possantes, onde, ondas, lama, sombria, casamento. Por fim, vale a pena citar algumas assonâncias que podem ser vistas talvez como uma espécie de rima interna, mesmo que "imperfeita”, como em pedras / austeras, flancos / possantes ou chagas / rasgadas.

É claro que a narrativa não é toda ela feita de frases como essa. No entanto, a existência desse período específico nos mostra o trabalho do escritor com a linguagem, a procura da expressão mais adequada, o refinamento do estilo, o apuro da técnica da escrita como antes talvez Cornélio Penna buscasse aprimorar a técnica da pintura, apesar das declarações em contrário. Essa constatação é fundamental tanto para reconhecermos o trabalho com a linguagem, como para nos colocarmos já em alerta contra uma visão ingênua da obra de arte como imitação da realidade. Mantendo sempre algum contato com a realidade - ainda que para se opor a ela - a obra é também uma realidade em si mesma. A análise deverá então se deter nas duas realidades: a realidade da linguagem e a realidade em sentido próprio, não qualquer realidade, mas aquela inscrita no romance ${ }^{52}$. E é em meio a essas duas realidades que a natureza surge, muito mais do que ocorria em Fronteira e em Dois romances de Nico Horta, em toda a sua complexidade, pois, ao passo em que demonstra hostilidade em relação aos homens, é imagem desses mesmos homens, sem deixar ainda de apresentar modificações advindas da ação transformadora deles. É por isso que as árvores são hostis, mas têm galhos famélicos, e as montanhas são austeras e apresentam chagas nos flancos, rasgadas pelos homens em busca de minério. Esse modo complexo de ver a natureza, por outro lado, encontra um correspondente na própria sintaxe igualmente complexa do período, constituído por meio da subordinação e nítido predomínio da hipotaxe sobre a parataxe. Ademais, talvez se possa adiantar aqui a observação de que a linguagem encantatória do

\footnotetext{
${ }^{52}$ V. cap. 4.
} 
fragmento transcrito como que mimetiza o poder encantatório que a natureza exerce sobre o homem.

A dicotomia natureza x cultura, que recobre e amplia, abstraindo, o par campo $x$ cidade, apresenta-se assim em Repouso de modo muito intrincado e escapa inteiramente a qualquer tentativa de redução maniqueísta. O melhor exemplo disso talvez seja o capítulo 36, em que Urbano e Dodôte às vésperas do casamento combinam e planejam um passeio fora da cidade:

Desde que Dona Rita e Siá Nalda tinham resolvido o seu casamento, que seria realizado com a maior brevidade, Dodôte e Urbano combinaram um passeio fora da cidade, como se esperassem dos momentos de liberdade absoluta no campo um maior entendimento entre eles, longe da presença opressora da avó, e do interesse afetado da velha amiga, que, quando os via, formava imediatamente em seu rosto a máscara da maternidade benevolente e risonha.

Faziam largos e minuciosos projetos, fechados na sala de visitas da Ponte, com a assistência distraída de Dona Rita, que ora permanecia sentada, rezando sofregamente o seu terço, ora entrava e saía, sem nada dizer, com a pressa e o afã de uma sentinela, mas também com o ar enfadado e ausente do guarda em seu mister.

Faziam largos e minuciosos projetos, como se a Ponte fosse muito longe, dentro de ruas e praças inumeráveis, em complicada trama, cheia de encruzilhadas e de esquinas desnorteantes, separada do campo e da mata por léguas de calçamentos de pedra e de casas entrelaçadas, que se estendessem aos quatro pontos cardeais.

Todos os detalhes foram longamente examinados, e Urbano tinha tido dias de inteiro desafogo, pois o professor fora ao Jirau e por ele se interessara enormemente. Tinha ficado lá, entretido com as instalações que tinham sido, em seu tempo, das mais aperfeiçoadas. A humilde "oficina", que Dodôte conhecia apenas pelo aspecto fantástico de fumo negro e de fagulhas, de construção áspera, de forja de grandes feiticeiros barbudos e revestidos de avental de couro, tinha sido vista por ele com olhos de admiração, por entre exclamações de profundo interesse.

Urbano e Dodôte, esquecidos de tudo, sentiam tanta e tão intensa vida naquela sala onde se reuniam, que era mesmo como se fosse necessário atravessar ondas humanas, longas séries de vidas anônimas, construções infindáveis para alcançar enfim a natureza livre, que era o ponto desejado por eles... 
Mas, na realidade, o campo abria-se, inculto, interrompido por valas e divisas, em alguns lugares cobertos de areias brancas com veios de cinza, mas vivo e variado, tendo sempre qualquer coisa muito verde, um grupo de árvores retorcidas, uma touceira de espinhos, uma sebe viva. Começava logo depois do velho muro que fechava o pomar, atrás da casa que se arrimava ao esteio da esquina, como uma velha vestida de branco ao seu bordão. Subia a encosta suave, coberta de pedras negras esparsas, e, em grande extensão, de grama verde-cinza, muito fresca, muito limpa, e que nunca refletia os raios do sol, sempre iluminada por uma luz macia, diferente, ao abrigo da sombra enorme do Pico, e própria dela mesmo.

Não era preciso percorrer um grande caminho para se alcançar o pequeno bosque, esquecido dos lenhadores e dos fazedores de pasto, que se erguia logo adiante do fim dos terrenos e da casa da Ponte.

(Repouso, p. 180-2)

Ainda aqui encontramos a homologia entre a complexidade da natureza e a da linguagem que a descreve, feita de longos e elaborados períodos. Primeiramente, a natureza surge como imagem, para Dodôte e Urbano, de liberdade e libertação das constrições sociais que se materializam na figura da avó, que representa metonimicamente a família e sua vigilância implacável, e de Siá Nalda, representante por seu turno do grupo social, caracterizada pela afetação e pelo fingimento, com o fito de esconder seus verdadeiros e escusos interesses, mascarados em amizade e benevolência. O paradoxo já se mostra no fato de fazerem, sobre a saída para o campo, "largos e minuciosos projetos, fechados na sala de visitas da Ponte". A insistência do narrador na repetição, no início do terceiro parágrafo, da primeira parte desse segmento que inicia o segundo - utilização de um procedimento típico da poesia, a anáfora -, seguida pela comparativa hipotética (como se...), a mostrar que um tal planejamento seria compreensível se o campo estivesse a uma distância considerável e se inúmeros obstáculos se colocassem no caminho que levava até ele, essa insistência enfatiza a extensão e o detalhismo desses projetos e ao mesmo passo aponta para o absurdo de se lançar mão do pensamento mais formal e abstrato na busca do contato supostamente libertador em meio à natureza.

Ocorre que essa situação paradoxal não é de modo algum apanágio exclusivo desse casal, mas está no centro mesmo da relação do homem com a natureza. Foi só por meio de um esforço desmedido e do pensamento mais abstrato que ele pôde obter o domínio da natureza, o que implicou o surgimento de uma distância intransponível até 
ela, na mesma medida em que se desenvolvia nele a nostalgia e o desejo de uma reintegração plena no mundo natural ao lado de um simultâneo terror de recair na indistinção anterior ${ }^{53}$. É essa ambigüidade, essa ambivalência que parece caracterizar a relação de Dodôte e Urbano com o campo. Os projetos tão minuciosamente elaborados e pensados colocam já um intervalo abissal em relação à natureza, antes mesmo de deixarem a casa da Ponte ${ }^{54}$ em direção ao campo, pois que "era mesmo como se fosse necessário atravessar ondas humanas, longas séries de vidas anônimas, construções infindáveis para alcançar enfim a natureza livre, que era o ponto desejado por eles..." A utilização do advérbio com sentido enfático como que retira o caráter hipotético da afirmação, mostrando que a distância - embora não fosse espacialmente grande, muito ao contrário disso, pois "começava logo depois do velho muro que fechava o pomar, atrás da casa..." - era de algum modo real, feita da superposição de um sem-número de gerações anteriores, responsáveis pela construção da sociedade e da civilização tal como eles as receberam e que carregam dentro de si como uma fatalidade inalienável.

Assim, onde começa o campo, onde termina a cidade ${ }^{55}$ Onde a cultura começa? Onde começa a natureza? Depois do muro velho da casa da Ponte? Mas e as árvores do pomar, não são também natureza? Não exatamente, pois foram plantadas pelo homem. Ora, as "plantas que se espalhavam em redor delas [das terras abandonadas] eram selvagens, apesar de terem sido outrora plantadas pelos homens", e entre elas "pedaços de muros [...] se levantavam aqui e ali, arruinados", sem simetria, sem mais cumprir o papel de cercar propriedades, "sem nunca se encontrarem". O que foi plantado pelo homem, de acordo com seu arbítrio e vontade, abandonado de seus cuidados, torna-se selvagem e intratável, e além disso, numa inversão ainda mais drástica e impressionante, as próprias ruínas daquilo que foi construído pelo homem, também abandonadas, retornam à natureza, deixam de obedecer às leis humanas da proporção e

\footnotetext{
${ }^{53}$ Sobre essas questões, v. Dialética do esclarecimento, de Theodor W. Adorno e Max Horkheimer.

${ }^{54}$ É sintomático o modo como é conhecida a casa da cidade. Como alguém já notou, essa "Ponte" pode recobrir vários sentidos, dentre eles, o de que ela permite (e também determina?) a volta ao passado para os que estão vivos e o retorno dos mortos ao presente.

${ }^{55}$ Em seu clássico estudo sobre o campo e a cidade, Raymond Williams nota logo de saída: "A realidade histórica [...] é extremamente variada. A 'forma de vida campestre' engloba as mais diversas práticas - de caçadores, pastores, fazendeiros e empresários agroindustriais -, e sua organização varia da tribo ao feudo, do camponês e pequeno arrendatário à comuna rural, dos latifúndios e plantations às grandes empresas agroindustriais capitalistas e fazendas estatais. Também a cidade aparece sob numerosas formas: capital do Estado, centro administrativo, centro religioso, centro comercial, porto e armazém, base militar, pólo industrial." ( $O$ campo e a cidade na história e na literatura, p. 11) Isto não significa que, a despeito dessas diferenças, não haja ao longo da história algumas associações, cuja descrição e análise é justamente o objetivo de Williams, mas vale como advertência para o cuidado que devemos ter ao tratar de termos tão genéricos como campo e cidade.
} 
da simetria e passam a se pautar pelas "leis" naturais do acaso e da gratuidade. Longe então de serem polaridades bem definidas e que mutuamente se excluem, natureza e cultura misturam-se de modo muitas vezes inextricável, o que acaba por mostrar como é complexa e problemática a relação do homem com uma e outra.

De todo modo, há uma oposição bem marcada entre o que provém da natureza e o que é criação humana. O que é próprio da natureza caracteriza-se pela irregularidade, pela desordem, pela falta de proporção e simetria, pela casualidade, pela ilogicidade e ausência de propósito. O que é feito pelo homem é, ao contrário, freqüentemente regular, ordenado, bem-proporcionado, simétrico, planejado, lógico e visando a um determinado fim. Assim, no capítulo 33, quando Urbano buscava já fugir sozinho da cidade, com o objetivo de obter ao menos uma evasão temporária, depois de sair da estrada, viu-se dentro "da verdadeira mata":

Irregular, ilógica, hostil, cheia de clareiras confusas e de cerrados espessos, distribuídos em desordem, emaranhados pelos cipós e pelas touceiras de espinhos, ora abria-se em pequenino jardim, atapetado de flores frágeis e ingênuas, ora erguia-se vertiginosamente em muralhas rugosas, impenetráveis, de pesados troncos escuros, cujas raízes se entrelaçavam como serpentes em luta. E surgiam as orquídeas sangrentas ou lutuosas, penduradas muito alto, repugnantes ou soberbas, mas sempre estranhas e surpreendentes. (p. 164-5)

Apresentando-se como absoluta alteridade, a natureza atrai o homem para o seu seio. Deixar-se levar significa recuperar a integração plena há muito perdida e a cessação da angústia, do sentimento de solidão e desamparo. Significa também a perda da distinção e a morte: "- Estou dentro da natureza, e tudo isto vive sem pensar..." "Mas, lembrou-se que devia voltar... que devia vencer aquela tentação de aniquilamento e de rendição, ..." É essa uma luta constante e uma fatalidade a que não se pode escapar a não ser deixando-se sucumbir, que é o que finalmente acontecerá com Urbano, personagem assim nomeado quem sabe com o intuito de sugerir a ironia trágica que rege a vida humana. É Urbano - o habitante da urbe, o morador da cidade, e ao mesmo tempo o civilizado - aquele que mais vai sentir os apelos da natureza, que atua dentro dele 
mesmo por meio da pulsão no sentido da volta ao estado de equilíbrio inicial inorgânico de onde todos proviemos, segundo Freud, a pulsão de morte ${ }^{56}$.

Não é somente essa natureza não domesticada que se apresenta à nossa mente quando pensamos no campo. Inevitavelmente também se apresentam imagens ligadas a cultivo, plantação, preparo do solo, colheita, criação, manuseio, cercamento, produção e outras, o que indica como a cultura (talvez não por acaso a um só tempo o nome do ato de cultivar a terra e o do complexo conjunto de comportamentos, crenças, instituições e valores de uma determinada sociedade) de algum modo orienta, quer o reconheçamos ou não, nosso modo de ver a natureza. É assim que Cornélio Penna insere, entre os projetos e preparativos de Dodôte e Urbano para a ida ao campo e a partida de fato, a menção ao professor e sua visita ao Jirau e a suas instalações, sobretudo à "oficina", com seu "aspecto fantástico de fumo negro e de fagulhas" e sua "forja de grandes feiticeiros barbudos e revestidos de avental de couro", nas recordações da infância de Dodôte. Antes de ser natureza, em que pese a maior proximidade dela quando comparada com a cidade, não apenas no sentido espacial, como também no que se refere às atividades, ao modo de vida e às relações entre o homem e tudo o que consideramos natural, é a fazenda então lugar em que a indústria humana intenta submetê-la aos seus propósitos. Desse modo, o que quer que reste da natureza, por mais mesclada e marcada pela presença e pela ação humanas, não há de ser encontrado nem na fazenda nem na cidade, mas entre a cidade e a fazenda. Esse entremeio compõe um "círculo mágico", onde reina o sonho e o "esquecimento sobrenatural", onde correm as águas "dançantes e sonoras" do riacho.

Nele instalados Dodôte e Urbano, nada poderia parecer mais deslocado. Se se sentiam estranhos na cidade ou mesmo na fazenda, é em meio à natureza supostamente livre e onde buscavam a liberdade que eles se sentirão menos à vontade, mas é onde poderá talvez surgir um pequeno vislumbre da superação de sua condição. Vestida de preto, com a longa saia a cobrir até os pés, calçados também de pano preto, e curiosamente carregando flores recebidas do professor de Urbano, "demasiado enfeitadas e belas, em excesso de luxo e de cores", e não flores simples do campo ali mesmo colhidas, Dodôte é observada por Urbano, que lhe notava o olhar perdido. E durante essa contemplação, pensa que nunca irá conhecê-la de fato, pelo menos não

\footnotetext{
${ }^{56}$ V., entre outros, Além do princípio do prazer. Josalba Fabiana dos Santos, no trabalho citado, teceu considerações semelhantes sobre o nome do personagem.
} 
com relação à camada mais profunda de seu ser, a despeito da ligação a que a família os constrangia (ou devido mesmo a essa ligação) e que em breve se realizaria formalmente. A aranha, sem suspeitar que aquele casal gigantesco ali estava apenas de passagem, tece o seu fio em torno deles, envolvendo-os em um "docel muito frágil". À observação de Urbano de que "a aranha é feliz", o que por contraste equivale à declaração da própria infelicidade sem remédio, Dodôte responde que sim, que ela "fica quieta e tudo vem até ela... para ser devorado!" E sentindo de algum modo os efeitos daquele círculo e sua magia, termina por rir, mas "com um riso pequenino, que não chegou a enrugar o seu rosto fechado e liso", para levantar-se confusa e declarar que precisavam voltar de imediato. Mesmo assim, é esse um dos raros momentos em que um dos dois personagens deixa-se levar pelo riso, mesmo que tenha sido tão tênue e tão fugaz. É um sinal talvez de que, por mínima que seja, é ainda possível que uma fresta se abra para a autenticidade e para a alegria pura e simples, que contudo logo se fecha para dar lugar novamente ao fingimento, à dissimulação, à tristeza e à melancolia inseparáveis da condição humana.

O círculo mágico da natureza resta assim mostrado em sua ambigüidade insolúvel de atração e repulsa, de possibilidade de superação da condição humana e causa de dissolução e morte, alteridade absoluta e vislumbre do reencontro possível com o próprio ser, imagem da felicidade simples e sem peias daquilo que não pensa e espelho em que se reflete, por inversão, a infelicidade daquele que não consegue deixar de pensar, que não consegue obter o desejado repouso. Mas a mais ínfima fenda que se abre mostra que é possível talvez obter algum tipo de apaziguamento que não seja o proporcionado pela morte, e é nesse sentido que veremos o desenrolar da história de Dodôte depois da perda do marido. Como foi esse repouso o resultado da união entre os dois personagens e como teremos com ele o desfecho do romance, antes de tratar dele diretamente podemos tentar compreender como foram narradas essas duas vidas paralelas até o momento do encontro e, mesmo depois que se encontraram, a vida que levaram juntos até a morte de Urbano.

No primeiro capítulo do livro, Dodôte contempla o interior da botica, os vidros dos remédios amarelados pela ação do tempo, vindos de muito longe, de terras distantes no exterior, ou dos arredores da cidade, mas de qualquer modo todos com letreiros estrangeiros e aspectos ameaçadores. A visão deles ativa a memória que relembra os momentos em que ela os arrumava, colocando-os nos lugares próprios de acordo com a 
"tradição sertaneja",57, tendo os seus movimentos acompanhados pelos "olhos opacos" de Urbano. A imagem dele nesse retrospecto, embora vivo, é a imagem da própria morte: "e, de vivo, naquela sala mal iluminada, existiam apenas aquele olhar sem calor e sem brilho, aquelas orelhas transparentes e destacadas da cabeça, deixando passar a luz através da carne exangue”. (p. 33) No parágrafo seguinte, tomamos já conhecimento de que ele morrera de fato e de que Dodôte iria vender tudo aquilo e ali estava apenas para se despedir da casa. A iluminação precária, o ambiente tétrico da farmácia com seu balcão de madeira negra, seus armários poeirentos em que grandes vidros espessos repousavam entremostrando em seu interior cobras e escorpiões - tudo o que ali se associava à morte a levava a imaginar, com um arrepio, que Urbano estava presente no recanto em que sempre ficava, mas é a memória que vai de novo buscá-lo e à sua atitude constante de fuga, sem que ela conseguisse explicar o motivo. Realiza então que não conhecera o homem com quem se casara e que amara, que lhe surgia agora como um "estranho" que houvesse invadido a sua intimidade. As reflexões e dúvidas acabam dirigindo-se a si própria e vê que a falta de compreensão que sente é sobretudo em relação a si mesma, sendo igualmente incapaz de compreender as pessoas com quem convivera desde a infância e que desde então a amavam, a avó e Chica.

É a partir dessas inquietações e desses questionamentos incessantes que se dá uma guinada na história rumo ao passado da personagem e sua família a partir do segundo capítulo, que tem como início o parágrafo comentado de modo relativamente exaustivo. Sem entrar em detalhes, tudo restando apenas sugerido, o narrador conta-nos de maneira extremamente concisa o casamento entre a mãe e o pai de Dodôte, que parece participar muito mais do pesar da morte do que da celebração da vida conjunta:

As flores de laranjeira caíam de lado, murchas, queimadas pelo fogo de seu rosto, e as velas do altar erguiam-se hirtas, e lançavam uma luz funérea e imóvel, esquecidas de que era uma festa nupcial que iluminavam. Pareciam velar um corpo e deixavam cair grandes gotas de cera, como se também chorassem... (p. 36)

Nada é dito sobre os motivos da tristeza da mãe e do pai dos noivos, nem quanto ao fato de o casal não mandar mais notícias ou pelo menos de nunca se falar nada a esse respeito, até que chega à fazenda uma menina acompanhada de uma negra velha e de

\footnotetext{
57 "primeiro, perto da porta, os simples mais procurados, depois os produtos de laboratório de saída imediata, e, mais adiante, os remédios velhos, muito antigos, alguns ainda intectos." (Repouso, p. 33)
} 
um moço, que logo evadiu-se na mata, pois diziam ser procurado pela polícia. Era Dodôte que vinha para ficar na companhia dos avós e que desde então substitui a mãe, a "outra", que "tinha olhos escuros e cabelos claros", prenunciando aqui o jogo de substituições que será central n' A Menina morta. Nada de mais concreto será dito sobre o destino dos pais de Dodôte, a não ser que tinham morrido, deixando na cidade um filho chamado José, que, se recusando a ir para a fazenda dos avós, por lá ficara até a sua morte, depois de ter contraído tuberculose.

Com a doença do avô e, sugere-se, com a decadência concomitante da fazenda mineradora, a família de Dodôte muda-se para a cidade, para a casa da Ponte. Lá, conhece a moça que viria a ser sua amiga, Maria do Rosário, que parece ter tido algum tipo de relacionamento com José. A relação entre ambas é complicada por esse fato e pelas enormes diferenças entre elas. Ao contrário de Dodôte, Maria do Rosário é expansiva, jovial, extrovertida, e não procura nunca esconder os seus sentimentos, o que não é absolutamente comum para uma personagem corneliana. Dodôte vive ensimesmada, mergulhada no passado e em recordações da infância, quase sempre recolhida na casa dos avós, a cuidar do avô, que a doença deixara praticamente imobilizado na cama, ou, quando sai à rua, na companhia da amiga, embora manifeste para si própria o desejo de atenção e o anseio por ser amada, volta-se o tempo todo para sua interioridade e para seus conflitos e questionamentos intermináveis.

Urbano só aparece no capítulo 20, mas a sua aparição não deixa de causar um certo estranhamento no leitor por vários motivos. O primeiro deles, e que a alguns parecerá mesmo uma incongruência do romance, é o fato de surgir de maneira inteiramente independente de Dodôte, e com o narrador mergulhado de todo em sua mais profunda intimidade. Como o romance parece desencadeado a partir das lembranças e reflexões de Dodôte no capítulo inicial, a expectativa é de que a narrativa fosse dada inteiramente do ponto de vista dessa personagem, da rememoração de sua vida, e que os outros personagens só se mostrassem junto dela. O segundo capítulo se explicaria pela importância do episódio do casamento dos pais para a compreensão da vida de Dodôte e teria a sua verossimilhança garantida pela simples admissão de que a história poderia ter sido contada a ela pela avó ou por outras pessoas com quem passou a conviver na fazenda do Jirau e que a teriam presenciado. Mas tudo isso agora cairia por terra, pois a história de Urbano, mesmo se ele fosse mais expansivo e falastrão, 
nunca poderia ter sido contada por ele a Dodôte com a riqueza de detalhes e o nuançado dos sentimentos íntimos que a narração de sua chegada à cidade apresenta.

Creio, porém, que não cabe aqui uma tal cobrança, pois o que o escritor parece buscar, mais ou menos conscientemente, é um outro modo de ver a realidade que amplie a sua compreensão, recusando-se a aceitar a verossimilhança como reprodução lógica e coerente da vida ${ }^{58}$. Essa busca parece resultado do sentimento de que a própria realidade quase nunca é assim tão lógica e coerente, mostrando-se avessa em muitos casos a quaisquer explicações e esclarecimentos, ou então da desconfiança de que possa haver uma outra lógica e uma outra coerência, distintas daquelas que conhecemos e que muitas vezes damos como inquestionáveis. O estranhamento que sentimos, então, seria muito mais resultado da intuição e do modo como o escritor compreende a vida do que da intenção consciente de provocar um determinado efeito. Muitas vezes sente-se esse mesmo estranhamento diante da realidade, e ele se constitui, ao mesmo tempo, num dos grandes temas do romance e de toda a obra corneliana. É assim que Urbano, logo ao chegar à cidade e depois de ter consultado o médico, entra na igreja sem dar-se conta disso, praticamente do mesmo modo como o narrador-protagonista de Fronteira e Nico Horta (no capítulo LI) haviam feito nos romances anteriores.

Só depois de andar mais um pouco, de abrir bem os olhos estremunhados, é que Urbano se apercebeu que tinha entrado na igreja, pois desmontara do animal e subira as escadas sem saber ao certo o que fazia, com a impressão intensa de ter chegado, de, enfim, poder descansar.

Os bancos eram altos e tristes, e ele, pelo tato, conseguiu alcançar um e sentar-se, deixando-se cair na dura madeira. Julgou que estivesse só, e não quis olhar para os lados, mas logo vultos imóveis que se perdiam na penumbra, apagados pela meditação e pela prece, o convenceram de que outros homens e muitas mulheres ali estavam, à espera da promessa cristã.

E das sombras, lá no fundo, ora iluminada pelos reflexos bruxoleantes [sic] dos lampadários, ora pela luz do dia, coada pelos vidros opacos, que a tornavam uma verdadeira chuva de cinza, surgia a grande imagem do altar-mor, fixada em seu gesto de angústia eterna.

Urbano fitou por muito tempo os olhos nas manchas de sangue, nos músculos parados na convulsão que vinha dos séculos, e todos os seus pensamentos se revoltaram e fugiram.

\footnotetext{
${ }^{58}$ V. capítulo 4.
} 


\section{$[\ldots]$}

Cruzou as mãos e rezou. As palavras vinham aos seus lábios sussurradas, em confusão, sem que ele as compreendesse, e sua boca movia-se independente de sua vontade, em um esforço cansado e sem vida, que não coincidia com os pensamentos passados pela sua mente.

Ajoelhara agora, e lançara o seu corpo sobre o peitoril do banco em sua frente, sem poder vencer a infinita lassidão que tornava o seu peito uma prisão de pedra, esmagadora, onde seu coração sufocava. Os braços e as pernas lhe doíam de forma lancinante, e todo ele sofria indizível martírio físico.

Mas, não tinha ânimo de se levantar, de caminhar até a porta, que se abria sobre a praça ampla e iluminada, e partir. (Repouso, p. 107-8)

Conheceremos depois, mesmo que de modo fragmentado e alusivo, um pouco da história de Urbano. Primo de Dodôte, desde o nascimento destinado a se casar com ela, em acordo estabelecido entre os pais de ambos, não se curvara num primeiro momento a esse destino imposto. Depois de conhecer uma moça chamada Maria do Carmo e por ela se apaixonar, casara-se com ela sem o consentimento dos pais e mudara-se para outra cidade. Ela teria contraído uma doença, sobre a qual nada de mais concreto é dito a não ser que a levara à morte, mas em pelo menos um momento Urbano deixa entrever em suas elocubrações que acredita ter sido responsável por isso, o que parece indicar a um só tempo o sentimento de culpa por ter transgredido as sagradas regras da família e a sensação de que o sofrimento e a morte da mulher eram o castigo recebido por essa transgressão. Ele mesmo sofreria de misteriosa doença, mas quase sempre associada à lassidão, à falta de ânimo para continuar a vida. Seria esse o diagnóstico do médico que ele procurara, pois que a prescrição recebida parece resumir-se à frase que fica em sua mente como um refrão: “- Viver, viver alegremente!” Mas seu corpo responde sempre a esse apelo com um cansaço invencível, uma desídia incontornável, um estado verdadeiramente abúlico que é espiritual, mas que tem visíveis reflexos ou correspondências no organismo: "Os braços e as pernas lhe doíam de forma lancinante, e todo ele sofria indizível martírio físico.” A assonância da vogal $i$, especialmente nas sílabas tônicas, parece o correspondente sonoro das pontadas agudas que o sujeito sente no corpo. A posição vergada, dobrado sobre si mesmo, passa a ser aquela a que invariavelmente o personagem recorre seja em busca de alívio para as suas dores, seja em função do peso da culpa que carrega. E mesmo quando não é desse modo descrito, a 
imagem que o leitor tem de Urbano é sempre essa: cabisbaixo, curvado como sob o efeito de um peso enorme.

Há uma certa inversão na descrição da imagem de olhos sangüíneos e músculos contraídos que parece fitá-lo do altar-mor e naquela de Urbano, com seus olhos sempre baços e musculatura flácida e sem vida. Mas, ao mesmo tempo, para sempre fixada na matéria morta utilizada pelo artista barroco, a angústia eterna, extensiva aos homens de todos os tempos. Outros homens ali também se encontram, em busca da realização da mesma promessa, à procura de consolo para o mesmo desamparo, de alívio para a mesma angústia. Urbano, porém, mal consegue pronunciar uma prece, sua boca não obedece à sua vontade, seus lábios pronunciam palavras que ele mesmo não é capaz de compreender, inteiramente diversas daquelas que procura formular em seu pensamento. Só lhe restava então deixar a igreja, mas nem forças para isso encontra perante o enorme desânimo que toma conta dele. Ficará ali então por um bom tempo, presa de "angústia tão terrível que parecia a aurora da morte”, o que o leitor sabe não demorará muito para ocorrer. Todo esse sentimento é dado porque o personagem não consegue a comunhão com o outro e, em seu isolamento, não atina com um sentido para a vida: "Ele era apenas (...), era somente uma reunião efêmera de restos disparates [sic], em constante dissolução, longe de sua vontade, estranho à sua consciência.” (p. 110)

Qualquer vislumbre de superação e de retomada da força vital que pudesse reverter esse estado de coisas a caminho da morte parece assim frustrado de saída. De todo modo, não será por vontade própria (e talvez resida aqui a principal causa desse outro fracasso) que Urbano irá intentar uma vez mais uma possível comunhão. Dona Rita, a avó, se encarregará de fazer com que, a despeito dos atalhos indevidos tomados por Urbano, o destino traçado pela família seja cumprido. Para isso, solicita a ajuda de Siá Nalda e a encontra, como sempre, pronta a desempenhar o papel de zelosa e desinteressada amiga da família, por trás do qual se esconde a intenção de conhecer tudo o que nela se passa, de influir em tudo que a ela diz respeito e de deixar patente essa influência perante toda a cidade. A intervenção e a consulta parecem encontrar acolhimento favorável tanto em Urbano como em Dodôte, mas longe está de provocar reações entusiasmadas. Em todo caso, há alguns momentos que indicam a possibilidade de que o casamento venha a dar certo e que possa fazer com que dois seres tão parecidos em sua solidão, em sua inaptidão para a vida, em seu desamparo, possam amparar-se um ao outro. Acontece que tudo parece ser feito para que a união não resulte bem-sucedida; inclusive, muitas vezes, as ações dos próprios personagens vão na 
direção contrária ao que se imagina seriam, ou deveriam ser, os seus mais fundos anelos. Há assim uma fatalidade a que não podem escapar, há um mau destino que se há de realizar, e seus próprios atos hão de ser em grande parte responsáveis por isso.

Nas tragédias gregas - pensemos, por exemplo, na história da família dos atridas ou dos labdácidas ${ }^{59}$-, a origem de todos os males encontra-se nas gerações passadas, nas disputas internas por poder e por heranças, e nos terríveis crimes fratricidas ou parricidas que acabam por gerar um interminável ciclo de vinganças. Em Fronteira, alude-se em diversos momentos a crimes e mortes violentas, embora nunca sejam inteiramente aclarados, mas a partir de Nico Horta as alusões tornam-se talvez ainda mais veladas. Em Repouso, há pelo menos uma menção explícita a "guerras de família", que tinham sido desencadeadas no passado pela posse de documentos antigos, que agora não deviam ter nenhum valor, e pela cobiça de pratas que se encontravam "amassadas e escurecidas" no momento em que a comitiva da avó as carregava, juntamente com aqueles velhos documentos, para a casa da Ponte, devido à decisão de se desfazer do Jirau. Mesmo sendo apenas uma e de certo modo tão genérica, essa alusão diz muita coisa, especialmente se juntarmos a ela os momentos em que se mencionam o ouro, os minérios e as minas, os tempos coloniais e as monções, os patriarcas autoritários, a opulência antiga e a mão-de-obra escrava, os túmulos ricos e os pobres, a riqueza da família proprietária da fazenda mineradora e a sua dispersão e o seu empobrecimento, e ainda Dodôte, apresentada como "bisneta do patriarca que governara a política da cidade" e "descendente de homens que tinham construído a cidade pedra por pedra", e depois como "a menina rica, filha de um homem faustoso, casado com a moça que viera de Minas Gerais, e trouxera a força de sua família poderosa", para que em pouco tempo se dê a "mísera decadência" de ambas as famílias, sem que se explicitem os motivos por que isso teria ocorrido.

Constitui-se assim, a despeito de tudo que há de velado na narrativa, um painel muito claro da família patriarcal mineira, cujo apogeu coincidiu com a descoberta das minas e dos minérios, e cuja riqueza e sua ostentação podem ser ainda hoje entrevistas na exuberância de suas igrejas e palacetes. Preocupadas com o risco da divisão das riquezas e propriedades recém-adquiridas, sendo também relativamente recente a sua chegada naquela região, vindos de lugares muitas vezes distantes, e tendendo assim a

\footnotetext{
${ }^{59}$ Os atridas são os filhos de Atreu, ancestral de Agamêmnon e Menelau; os labdácidas, os descendentes de Lábdaco, como Laio, Édipo e seus filhos-irmãos.
} 
desconfiar de tudo e de todos, essas famílias faziam com que seus membros se casassem entre $\mathrm{si}^{60}$, mas obviamente os filhos nem sempre se sujeitavam às injunções paternas, dando origem a cisões e rompimentos que podiam por sua vez levar a crimes e guerras no interior mesmo das famílias, sobretudo quando entrava em jogo a disputa por bens e heranças. Mesmo, contudo, nos casos de aceitação das regras do jogo, não estavam descartados de modo algum tensões e conflitos. Voltadas para si mesmas, sem abertura, sem respiro para o estabelecimento de outras relações, mais efetivas e duradouras, que não fossem as familiares, forçando seus membros a se casar sem que muitas vezes existisse afeto verdadeiro entre os futuros cônjuges, sujeitos então aos maiores riscos, advindos da união entre consangüíneos, de transmissão de doenças hereditárias aos descendentes, pautando as ações e relações, intra e extra-familiares, unicamente por interesses econômico-financeiros, explorando a terra de modo predatório e sobretudo com o uso do trabalho escravo ${ }^{61}$, utilizado igualmente nos serviços domésticos e na criação dos filhos, o que fazia com que a desumanidade da relação senhor / escravo adentrasse a casa senhorial, essas famílias entravam freqüentemente num ciclo que envolvia doença, depressão, loucura, ódio e violência, que por sua vez levavam igualmente a crimes, guerras e dissolução.

Esse contexto, no caso de Urbano e Dodôte, é agravado pela decadência, e é difícil pensar que o sentimento deles de desamparo e de inadaptação não tenha qualquer relação com a história de cada um e de suas famílias. Sem querer absolutamente desconsiderar o que há de particular, de próprio de um indivíduo singular, é preciso reconhecer que essa história tem na origem desse sentimento um papel tão decisivo que ambos acabam por compartilhar as mesmas vacilações e hesitações, o mesmo desconforto, a idêntica sensação de isolamento e solidão, bem como os anseios pela superação dessa condição, pelo encontro e comunhão com o outro, sempre frustrados, em muitos casos pelas próprias ações ${ }^{62}$. A maior diferença reside no fato de Urbano ter tentado se furtar ao peso dessa herança fatídica, enquanto Dodôte - por se sentir talvez mais fragilizada, sendo mulher, numa sociedade patriarcal, e órfã de pai e mãe, tendo vivido, mesmo quando seus pais ainda eram vivos, sob os cuidados e a tutela dos avós até o fim a ela se submeteu. Sem se desconsiderarem outros motivos, é provavelmente

\footnotetext{
${ }^{60}$ Seria por esse mesmo motivo que dona Ana levara Nico Horta a se casar com Maria Vitória?

61 "A verdade é que a grande lavoura, conforme se praticou e ainda se pratica no Brasil, pratica, por sua natureza perdulária, quase tanto da mineração quanto da agricultura. Sem braço escravo e terra farta, terra para gastar e arruinar, não para proteger ciosamente, ela seria irrealizável." (Sérgio Buarque de Holanda, Raízes do Brasil, p. 18)

${ }^{62}$ V. cap. 4.
} 
no malogro da tentativa de escape que se encontra a razão da maior vulnerabilidade de Urbano em relação a Dodôte e o de seu perecimento, anunciado logo no primeiro capítulo do livro. $\mathrm{O}$ homem que chega à cidade, como foi visto, é um homem derrotado, cabisbaixo, dobrado sob o peso do fracasso.

Não há então por que um ou outro se recusem a fazer a vontade da avó, mas fazer essa vontade é uma vez mais submeter-se aos desígnios dos espectros que circulam pela casa. Assim, eles se casam, num casamento em que a noiva vestia um "pobre vestido de seda branca, sem um enfeite, parecendo mais destinado a uma noviça, para a entrada definitiva em religião", para depois do casamento passar a trajar-se invariavelmente de preto, como se estivesse o tempo todo de luto, enquanto o noivo, na véspera, perde-se em sombrias recordações de uma história contada na família, despertadas pelo quarto da "mão negra", nome já de si sugestivo, para o qual se dirige à procura de uns botões de ouro e ônix negro que usara no primeiro casamento. Uma tiaavó paterna, a mais moça da irmãs, projetara fugir com o namorado, "para a desgraça certa", e entrou naquele quarto pouco antes do horário com ele combinado para pegar um capote com que pudesse se disfarçar. Enquanto o procurava, sentiu uma mão prender o seu braço com força descomunal e, com o quarto na penumbra, só teve tempo de ver, antes de desmaiar, que era uma mão negra enorme, acabando por despertar apenas quando o companheiro de fuga tinha desaparecido. Assim ficou aquele quarto conhecido por esse episódio aterrador. Não parecia mesmo de bom agouro uma lembrança como esta no dia imediatamente anterior ao casamento. Este é narrado em grande medida do ponto de vista do professor e não poderia ser mais melancólico. Tendo sentido o quão triste era tudo naquela cidade, tão diferente de suas expectativas, e a distância enorme que na verdade o separava de Urbano, o professor decide partir, com a consciência de sua incontornável solidão, logo depois de terminada a cerimônia assim descrita:

Tudo se passava como se aquelas figuras que tinha diante dele se tivessem levantado, descoladas, de imagens muito velhas, por entre páginas gastas de livros abandonados em bibliotecas sem leitores, e eram fantasmas sem nome e sem vida, que andavam em passos surdos e gestos contidos, com medo de se desfazerem em pó, de um lado para outro. Obedeciam maquinalmente, como bonecos, ao ritual que devia estar escrito, regulando todos os detalhes, nos livros que via nas mãos dos 
assistentes, que o acompanhavam e olhavam de quando em quando para o altar, junto ao qual ele se achava, como para verificar a sua exatidão. (Repouso, p. 195-6)

Vindo de uma cidade grande não nomeada ou pelo menos, imagina-se, uma cidade maior que aquela onde viviam Urbano e Dodôte, o professor parece terrivelmente decepcionado com a falta de naturalidade dos moradores do lugar. Cansado talvez da representação de inúmeros papéis que caracterizava a sociedade que conhecia, imaginava que naquela pequena cidade encravada nas montanhas encontraria a vida simples, natural, sem fingimentos, e somente encontrara pessoas agindo "maquinalmente, como bonecos", seguindo à risca um ritual que estava escrito e predeterminado nos menores detalhes, isto é, tudo o que tão bem conhecia. Diante disso, volta para sua cidade, muito provavelmente para não mais retornar, mas o escritor - se também voltou, depois de algumas semanas, de Itabira para o Rio de Janeiro - levou consigo todo aquele mundo, parece que nunca mais conseguindo dele se desprender de todo. Alter-ego do escritor, o professor nos ajuda a compreender a recusa de Cornélio Penna em figurar o meio em que vivia e em que quase sempre viveu, as cidades grandes e as capitais, e também, de algum modo, o seu tempo. Tudo nessas cidades e nesse tempo apontava para aquilo que mais o desgostava: o fingimento, a dissimulação, a representação de papéis de acordo com o momento e os interesses, muitas vezes mesquinhos, as ações maquinais e automáticas, as obrigações e imposições sociais, a opressão e a falta de liberdade. Dessa ojeriza teria nascido o desejo de buscar e representar um outro mundo, menor, mais simples, mais próximo do campo, da natureza, mais livre ou menos opressivo, onde cada um pudesse ser o que de fato se é. Nessa procura, porém, ele encontra nada mais nada menos do que a origem de tudo o que visceralmente abomina ${ }^{63}$. E, por ser de fato menor e, em certo sentido, mais simples, tudo ganha uma dimensão impressionante, tudo se exacerba, sobretudo a opressão, advinda da estrutura social baseada na família patriarcal, e o conseqüente desamparo, de que todos são um pouco vítimas, sem também que um deixe de ser em alguma medida algoz do outro. O mais terrível, contudo, é que, como nas tragédias, todos também acabam vítimas e algozes de si mesmos, responsáveis por sua própria infelicidade e infortúnio. Como sabemos, Cornélio não desistiu de figurar esse mundo (embora tenha buscado, no próximo romance, a representação de um outro mundo,

\footnotetext{
${ }^{63}$ Essas reflexões tiveram origem a partir de uma observação feita pelo prof. Ariovaldo José Vidal durante o exame de qualificação.
} 
distante desse no tempo, ainda mais recuado, e no espaço), provavelmente não só porque não havia como recuar da tarefa a que se impôs, como porque estava totalmente impregnado dele, e ainda porque a relação com ele era ela própria ambivalente, feita não apenas de ódio, mas também de amor, inúmeras vezes explicitamente manifesto, despertado até mesmo porque talvez de algum modo nele se reconhecesse.

Depois do casamento, o narrador passa a descrever a instalação de Dodôte e Urbano na casa da botica, que fora outrora residência dos tios, agora "sogros", já falecidos. Nela, Dodôte diz a Chica que deixe "tudo exatamente como esteve sempre", nada cedendo diante do desagrado da ama, de seu questionamento espantado e de sua argumentação em contrário. Além disso, como foi mencionado, Dodôte continua a usar vestidos negros, prosseguindo no luto interminável, agora com o pretexto de que o avô não a vira vestida de noiva e, como a via sempre vestida de negro, parecia-lhe um sacrilégio utilizar então outra cor. Sentia, porém, que não deixava de ser "teatral aquele luto que muito pouco se justificava". O mínimo que se pode dizer é que essas atitudes não parecem provir de quem acredita estar entrando numa nova fase da vida em que irá finalmente encontrar a felicidade desejada e que sabe ser necessário, para que isso ocorra de fato, alguma contribuição de sua parte, pelo menos quanto ao preparo de um ambiente propício e ao uso de vestimentas propiciatórias da alegria que se imagina há de vir. Junte-se a isso o fato de que o casamento dava-se sobretudo por imposição da avó e da família, e tem-se o enredo de uma "tragédia anunciada".

Isso ainda não é tudo. Urbano nem parecia reparar na roupa que a mulher usava já que ele também sempre se vestira de preto. Os passeios do casal enlutado pela cidade eram sempre pontuados por referências ao tempo pretérito: “- Aqui morou Sinhá Ema..." "- Aqui morou tia Tota... você se lembra?" "- Você lembra-se?" As conversas dentro de casa eram também sempre relativas a "pessoas amadas e mortas", como se eles, não satisfeitos por saber que a sua união era o resultado de uma decisão tomada por quem já havia morrido, insistissem em viver o tempo todo na presença de espectros e fantasmas. O passado também se imiscui e toma conta do presente na atividade de Urbano, que reabre a farmácia que fora do pai e do avô, o "velho boticário", com o mesmo mobiliário antigo e enegrecido e a maior parte dos antigos vidros e frascos de remédios e venenos, agora amarelados e cobertos de pó. Dodôte mantém-se, durante boa parte do dia, do lado de dentro da farmácia, separada do balcão por um grande armário e invisível para as pessoas que passam a utilizar a botica como ponto de 
encontro em que entretêm "longas palestras, sonolentas discussões inteiramente ociosas”, enquanto Urbano dedica-se aos afazeres cotidianos naquele ambiente sombrio. Num casamento assim tão marcado pelas sombras dos mortos, não demora muito para que Dodôte descubra que ela e o marido eram e seriam para sempre estranhos, que nada tinham a dizer um ao outro, que ela não queria mesmo ouvir nada dele. Como refúgio, passa a visitar a avó com freqüência e por largo tempo antes de voltar para casa.

Instigada por Maria do Rosário a comparecer à missa de domingo, com a menção ao fato de que o padre notava a ausência dela aos domingos na igreja, Dodôte sai com a amiga sem esperar por Urbano, mas somente depois de ter pedido que ele também se preparasse para ir com elas à missa. Na frente da igreja, em meio à multidão, Dodôte espera ansiosa por Urbano, até que o vislumbra, parado junto ao degrau de pedra que dava acesso adro, sem conseguir erguer os pés para franqueá-lo. Dodôte desce então ao seu encontro e, abaixando-se, segura o pé direito do marido e o ergue na direção do degrau, dando-lhe depois o braço e seguindo com ele para o interior da igreja. Já eram então comuns os comentários dos freqüentadores da botica sobre o alheamento e a indiferença crescentes de Urbano, a sua saúde cada vez mais debilitada, a desconfiança de que não fossem apenas problemas de saúde, e alguma estranheza com o que parecia ser o pouco envolvimento da mulher com o problema, tendo Dodôte ouvido muitas dessas conversas ao se manter oculta atrás do armário. A viúva, um personagem folclórico e agourento, que regularmente freqüentava a casa de Dodôte e a farmácia, já fizera algum tipo de alusão a esse respeito. Sobretudo para quem a conhece por experiência própria, é notável como Cornélio consegue, em momentos assim, dramatizar com tanto acerto a vida em uma pequena cidade do interior, com tudo o que nela há de apatia, de modorra, de mesmice, de vigilância e tagarelice sobre a vida alheia e de falta do que fazer, o que também aparece - obviamente, de modo diverso e com um outro tom - em alguns notáveis poemas do itabirano de nascimento Carlos Drummond de Andrade.

Em bilhete enviado pela avó, por intermédio de Chica, ela avisa Dodôte que devia acompanhá-la ao Jirau para providenciarem a mudança do que ficara na fazenda, pois que a sua venda já estava praticamente concretizada. Dodôte não se conforma com a decisão, mas responde que "estava pronta para tudo, mesmo para aceitar a idéia da fazenda passar para mãos estranhas". Procura não se estender muito na conversa com Urbano sobre isso e apenas começa a se preparar para ir ter de madrugada com a avó. É 
aqui que para mim se encontra o ponto alto do romance, o momento em que Cornélio Penna demonstra nítido domínio da técnica da escrita e inteira segurança no seu uso. Em dois capítulos, 54 e 55, o narrador se acerca ora de Dodôte, ora de Urbano, fixandose aqui na interioridade de um, ali na do outro, e, estando separados, mas em determinados momentos muito próximos, sem saber exatamente das ações um do outro, eles não têm nunca a certeza do que ocorre com o parceiro, mas têm sempre uma suposição, colocada logo sob suspeita. Assim, enquanto Dodôte efetiva, com a ajuda de Chica, os preparativos para partir, Urbano recolhe-se ao seu quarto, de onde apenas pode ouvir os ruídos provocados por elas. Há também o uso de dupla narração, em seqüência ou sucessiva, de momentos simultâneos vividos pelos dois personagens. A partir da metade do capítulo 54, o narrador centra-se em Urbano e irá acompanhar todos os seus pensamentos, inquietações e anseios, seu estado de torpor e sonolência, seus sonhos e pesadelos, a alternância entre momentos de lucidez e delírio, os presságios e pressentimentos da morte que chegava e, finalmente, ao terminar o capítulo, a morte descrita - se não exagero - de maneira magistral:

Tornou a volver-se para o outro lado, e ficou imóvel por muito tempo, mas já não podia ficar tranqüilo. Todos os seus nervos se agitavam e o coração voltava a bater precipitadamente. Tentou levantar-se em supremo esforço, conseguiu reunir os membros, que pareciam esparsos longe de seu corpo, como se tivessem morrido antes dele, e pousou os pés no soalho. Pensou que era pó, por que pois deixar-se invadir por aquele horrível tormento, que lhe parecia pior que as chamas altas de uma fogueira? Ao dar o primeiro passo, teve a sensação de flutuar, e voltou a sentar-se. Agarrou-se ao espaldar, mas, ao erguer a cabeça, para uma segunda tentativa, viu fixos nos seus os olhos de vidro de uma imagem tosca que o fitavam, de cima da sua mesa da cabeceira.

Sentiu que se acalmava, que a lucidez lhe voltava chamada pelo brilho daquele olhar, e pensou que estava naquela expressão parada e mal feita, no terrível significado que tinha, a solução de seus problemas, que apenas entrevira uma só vez em toda a vida.

Refletiu que em si e de per si nada valia, nada representava, senão o reflexo daqueles pequenos focos luminosos que o banhavam com seus raios, e o tornavam alguém, pelo amor que deles irradiava...

Suas mãos muito pálidas e incertas, agora inocentes, alcançaram a mesa de trabalho, de pinho branco, que pusera perto da cama, do seu lado, para terminar 
mais depressa a pesquisa que estava fazendo, e que representava tudo para ele. Conseguiu alcançar a cadeira e sentou-se. Mas suas forças estavam esgotadas, e não pôde sustentar o busto que caiu pesadamente sobre as retortas e os provetes que tinha diante de si. Ouviu ainda o tilintar dos vidros que se partiam sob o impulso de seu rosto transfigurado, e o som dos cristais longos e escuros que se espalhavam e caíam no pavimento.

Com um movimento muito doce, cheio de ternura, pousou a cabeça sobre a tábua, onde corria o sangue vermelho de suas feridas. Estava tão cansado, e agora ia fechar os olhos e repousar, para sempre, na paz sem fim... mas suas pálpebras se reabriram, e as pupilas, se bem que mergulhadas em trevas viscosas, tinham agora um olhar enigmático, insustentável...

(Repouso, 283-4) ${ }^{64}$

O capítulo 55 se inicia com: "Na manhã do mesmo dia, Dodôte, em caminho para o Jirau..." Praticamente nada, porém, do que na fazenda se passara é narrado, mas apenas a chegada de Dodôte à casa da avó, a partida para o Jirau e o percurso, realizado ao entardecer, da volta à casa da Ponte, tudo sempre permeado pelas reflexões incessantes de Dodôte sobre Urbano. Perguntava-se o tempo todo se ele estaria realmente dormindo quando ela entrara no quarto para despedir-se dele e o ouvira pronunciar, em meio a frases confusas e sem nexo, a palavra terrível: "- Monstro!" No capítulo anterior, o narrador mencionara a aproximação de um vulto que dele se aproximara e murmurara confusas palavras, sendo repelido por Urbano com rispidez: “ - Sai, sai daqui, eu te odeio..." Só agora nos damos conta que esse vulto não era fruto de sua imaginação atormentada e, sim, Dodôte, mas o estado de semi-delírio de Urbano não nos permite saber com nenhum grau de certeza se ele tinha consciência de que fosse ela, ou se ele, mesmo inconscientemente, declarava o seu ódio à mulher. $\mathrm{O}$ mesmo pode-se dizer da palavra "monstro" ouvida por Dodôte; era a ela que se dirigia o insulto? A dúvida de Dodôte, que nunca poderá ser esclarecida, é também a dúvida do

\footnotetext{
${ }^{64}$ Josalba Santos, baseando-se no episódio em que Dodôte lê no rótulo de um frasco o nome Uabaio, lembrando-se que Urbano lhe dissera ser um veneno muito poderoso, sugere que ele poderia ter se suicidado. As semelhanças entre o nome do veneno e o de Urbano são de fato intrigantes e perturbadoras, e a possibilidade apontada não deixa de fazer sentido. (Fronteiras da nação em Cornélio Pena, p. 84.) Mas é também possível que ele, inapto para a vida e mesmo desgostoso dela, ao contrário, lutava inultimente contra a doença que o fazia definhar, o que evidenciaria uma vez mais as contradições do homem e sua complexidade. Se assim for, nesse mesmo capítulo, o outro frasco, cujo rótulo a viúva lê apenas com o movimento dos lábios, mas demorando-se indiscretamente diante dele, poderia ser de um medicamento muito forte e específico, para uma doença grave e passível de identificação. Por fim, a linha que divide o veneno que mata do remédio que cura é por vezes muito tênue, e em alguns casos a diferença reside apenas na quantidade ingerida. De fato, o "ácido ósmico" parece ser usado para combater os efeitos da artrite reumática.
} 
leitor. Com a morte de Urbano, o mistério instala-se para sempre, e o narrador não parece ter a menor pretensão de ter a resposta. Trata-se de mais um exemplo, e dos melhores, do modo como Cornélio obteve a representação do desconhecimento que se instaura na vida mesmo, a despeito de se acreditar ou não na existência do sobrenatural, de almas do outro mundo ou de fantasmas. É só por uma falsificação dessa realidade que um escritor, por meio de um narrador onisciente, pode arrogar-se o conhecimento de toda a verdade. Nesse sentido, a literatura de Cornélio Penna é inegavelmente moderna, podendo-se dele dizer o que Auerbach disse em relação a escritores como Virginia Woolf, que se colocam "como quem duvida, interroga e procura, como se a verdade acerca de sua personagem não lhe fosse mais bem conhecida do que às próprias personagens ou ao leitor" ${ }^{\prime 65}$.

Na volta, depois de ouvir "o grito solitário de um pássaro", Dodôte não consegue afastar de si a idéia de morte que lhe ocorrera. E toda a paisagem percorrida é cercada de signos que prenunciam, ou melhor, anunciam - pois ela já teria ocorrido - a morte de Urbano:

Ficou parada, por algum tempo, e olhou em torno de si. De um lado e de outro abriam-se vales profundos, já mergulhados nas trevas e ocultavam cautelosamente o segredo pungente de seus brejos, cobertos de lírios envenenados, cujo encanto maléfico chegava até suas narinas em ondas carregadas de estonteante odor." (p. 289)

A pequena caravana chega então à cidade, e, com a escuridão que se vai fazendo aos poucos, aumentam a melancolia e a angústia sentidas por Dodôte, ansiosa por chegar e por se encontrar com Urbano. Depois de deixar a avó na casa da Ponte, dirige-se com Chica para a farmácia. A partir daqui a narração encontra-se repleta de índices da morte de Urbano: "o silêncio se tornou absoluto", "Havia uma calma de sono profundo, que fazia da rua uma grande alcova."; "paz profunda e um pouco assustadora"; "tranqüilo repouso"; "parecia-lhe inquietante, ameaçadora, a calma que a rodeava". E torna-se ao mesmo tempo muito lenta, descrevendo passo a passo a entrada das duas mulheres na casa às escuras. Dodôte nota, contudo, uma réstia de luz por baixo da porta de seu quarto, mas isso a tranqüiliza, pois imagina que Urbano já dormia e se esquecera de

\footnotetext{
${ }^{65}$ Mimesis, p. 482.
} 
apagar a luz ou deixara uma lamparina acesa. A entrada de Dodôte no quarto é então descrita do "ponto de vista" de Chica, que se dirigira

para a cozinha levar a simples bandeja de madeira em que pusera a tigela de leite, o açucareiro e os biscoitos. Ao sair da sala escutou ainda o som hesitante dos passos de Dodôte dentro do aposento, mas logo, transida, fulminada de terror no lugar onde estava, ouviu um grande grito, que estrugiu de repente, sobre-humano, em duas notas, uma aguda e outra grave. (p. 293)

Tudo fica assim a cargo da imaginação do leitor: os passos cuidadosos de Dodôte na direção da cama, para não acordar Urbano; a visão terrível do corpo caído sobre o tampo da mesa de pinho branco, em meio aos fragmentos de vidro e ao sangue coagulado; o susto tremendo seguido dos gritos ouvidos pela ama. A ama fica um instante imóvel, petrificada pelo espanto, e só depois de levar a bandeja, lavar a louça e arrumar tudo meticulosamente, é que se dirige ao quarto e, quando a porta se abre, cai desmaiada no chão em frente a Dodôte, que ali surgira extremamente pálida.

A partir desse momento, o leitor sente que o desenlace se aproxima. Os momentos seguintes à morte de Urbano até o velório e o enterro são apenas ocasiões em que Dodôte tem de fingir a tristeza e o desespero que não sente, isto é, mais um papel que reclamam que ela represente e que ela se sente incapaz de representar:

Pensava, no fundo de si mesma, e sentia triste vergonha por ter esses pensamentos, que devia chorar, e talvez até desmaiar, como vira outras viúvas fazendo... mas seu espírito estava terrivelmente lúcido. Nem, de leve, sentia suas mãos tremerem, e os lábios estavam apenas secos, sem mais nada. (p. 301)

A demonstração de pesar e comiseração por parte daqueles que nem eram assim tão próximos, as lágrimas que pareciam correr tão facilmente em seus rostos, diante do seu desconforto e da dificuldade em assumir o papel que lhe cabia ("Era muito pesado o papel a representar, ...”), tudo isso se somava à palavra que ela não conseguia tirar da cabeça, "monstro", e as lágrimas que finalmente caíam pareciam-lhe derramadas não pela morte de Urbano, mas por si mesma, e o epíteto era sentido assim como inteiramente adequado para a própria caracterização, tão egoísta ela passava a se achar. 
Exatamente no capítulo 60 cessa a narração em flash-back iniciada no segundo capítulo. Depois do enterro de Urbano, que Dodôte não acompanha, é dito que a avó e a ama resolveram levá-la imediatamente para a casa da Ponte. A reinstalação de Dodôte na casa da avó é, não por acaso, narrada em meio à descrição do panorama montanhoso que cercava a casa e dos céus que prenunciavam a tempestade. Dodôte, logo ao chegar, caminha para a janela, "de onde, por sobre o muro baixo do quintal, podia avistar o vale e, no fundo, a montanha toda de ferro que se erguia, ameaçadora." (p. 311) Depois, "negras e disformes, como grandes máquinas de guerra, que se concentravam para dar assalto ao gigantesco castelo do Cauê", numa descrição que ecoa o concílio dos deuses camoniano, as nuvens reúnem-se no céu:

Desfraldavam altos estandartes rubros e luminosos, e lançavam rápidas fagulhas, que revelavam o fogo destruidor trazido em seus seios. Mas agora, havia um tumulto, e devia realizar-se temeroso conselho entre elas, pois, após surdos trovões, hesitaram, voltaram sobre si mesmas, e vieram ao assalto da cidade, calada e encolhida de pavor, lá em cima, na presciência de que seria ferida até os alicerces. (p. 312)

A nomeação do conhecido Pico explicita a localização geográfica até então apenas sugerida, não deixando mais dúvidas, se acaso ainda existissem, de que a cidade assim personificada é Itabira. E é ainda com a utilização do procedimento poético da personificação, dentre outros recursos, que a tempestade que se abate sobre a cidade e sobre Dodôte é descrita de modo admirável e impressionante:

$\mathrm{O}$ vento, morno, violento e indeciso, carregado de poeira e de odores amargos, como se tivesse varrido estradas e percorrido as superfícies mortas de brejos imensos, bateu em seguida bofetadas no rosto de Dodôte, modelando-o com aspereza brutal. Quando ela abriu os olhos, que fechara sob a impressão de repentina agressão, viu as árvores do pomar que, por cima do muro que as separava do pátio, sacudiam desesperadamente os galhos, como longos braços em pedidos de socorro, no pavor de perderem seu laborioso equilíbrio e prepitarem-se no rio, agora torvo e caudaloso.

De repente ouviu-se e cresceu vertiginosamente o tropel martelado de milhões de cavalos de guerra, carregados com cavaleiros cobertos de esmagadoras 
armaduras. Gritos confusos, apelos, lamentos e risos encheram o ar, logo dominados por um ronco profundo, prolongado, que reboou pelas encostas e fez tremer as entranhas de ferro de todo o vale.

E veio a água, pesada, sufocante, impenetrável. (p. 314)

A sequiência dos três parágrafos transcritos, indo gradativamente daquele de maior para o de menor extensão, parece espelhar os três tempos em que se desencadeia a tempestade. Primeiro, o momento mais demorado em que Dodôte sente o vento furioso na face por ele fustigada e pode vê-lo indiretamente no movimento das árvores e das águas do rio; depois, um pouco mais breve, ouve os trovões e os ruídos provocados pelos que esperam temerosos pela tempestade e que procuram se preparar para enfrentála; e, por fim, desabando de uma só vez, sem deixar mais qualquer espaço para a visão ou a audição do que quer que seja, a água toma conta de tudo.

Trata-se de uma tempestade tão violenta que o telhado da casa da Ponte não resiste e cede justamente acima do quarto de Dodôte, em diversos pontos, e a metáfora utilizada pelo escritor remete à decadência final da família, materializada na casa que era como que dissolvida pelas águas da chuva: "O abrigo que recebera, o refúgio, que o fora de tantos homens e mulheres de seu sangue parecia desfazer-se, ameaçava desabar..." Dodôte, já ensopada, corre para um outro compartimento no térreo, deitando-se sobre uma arca, e, ao retirar com as mãos parte da camada de pó que a recobria, a madeira negra e lisa a leva a associá-la ao caixão de Urbano e em seguida ao cemitério onde fora enterrado, para depois imaginá-lo saindo do túmulo e dirigindo-se a ela, aproximando-se todo molhado e tiritando de frio, até sentir que alguém realmente dela se aproximava e procurava erguê-la. Era a avó, junto com Chica, e na fala que aquela pronuncia é sugerido o que será explicitado no capítulo seguinte: “- Você não deve descuidar-se assim, minha filha - (...) - foi nossa culpa, pois deixamos você sozinha, no seu estado...” (p. 318, grifo meu).

Dodôte estava grávida de Urbano e irá enfrentar uma gravidez de risco não apenas para o bebê como para si mesma, pois é acometida pela doença logo depois da tempestade, resultado provavelmente tanto de causas físicas quanto emocionais e psíquicas. Fica entre a vida e a morte até faltarem poucos dias para o nascimento do bebê e chega mesmo, depois da conclusão a que chegaram os médicos de que nada mais podia ser feito, a receber do padre a extrema-unção. Acaba, porém, se recuperando e sobrevivendo, "ressurreição" que deixou a todos estupefatos. Durante a geração do 
bebê, cujo pai já morrera, manifestam-se uma vez mais as superstições profundamente arraigadas naquela sociedade que parecia constituir um mundo à parte no topo da montanha: "parece-me o filho de um fantasma", Dodôte ouvira a viúva exclamar, e, ao comentarem a doença de Dodôte, murmurava-se na cidade que "havia ali influência do Diabo”. Curiosamente, circula uma história sobre a própria viúva, em que se afirma que ela nem era viúva de verdade, nem nunca havia se casado de fato, e Maria do Rosário procura um dia despertar o riso de Dodôte contando como a pretensa viúva estaria fazendo um enxoval para a criança, tendo feito inclusive algumas peças em preto e roxo para o luto pelo pai.

Durante a convalescença de Dodôte e quando está prestes a dar à luz, morre a avó, D. Rita, que parecia ser a única pessoa que restava de sua família. Não há contudo muito tempo para chorar a sua perda. Dados os primeiros sinais de que o nascimento iria se dar, a viúva e Siá Nalda, que haviam se distanciado da casa da Ponte pouco antes da morte de D. Rita, por sentirem que esta e a neta não lhes davam a atenção e a abertura que acreditavam ser delas de direito, é que correm em seu auxílio, enquanto Maria do Rosário procura pelo médico. Na tarde daquele dia, nasce um menino, e Siá Nalda e a viúva olham espantadas para ele, "como se estivesse morto", até "ouvirem os gritos estridentes que soltou", enquanto outros "lá dentro" faziam "desaparecer os últimos vestígios do enterro que tinha saído horas antes". O estranhamento, contudo, continua, e as duas interrogam o médico, que examina o bebê sem nada dizer, mas verificando que havia algo de errado com as pernas do recém-nascido. Só se manifesta diante da pergunta de Dodôte, feita com voz fraca mas calma, que indagava se seu filho era aleijado. Numa resposta negativa, mas confusa, ela percebe que, entre outras, se destaca a palavra "tabes". Então, mais do que tudo o que havia sofrido nos últimos meses, o sofrimento que sente diante dessa revelação é que parece justificar o seu nome, Maria das Dores. Lembra-se de todas as perdas que sofrera e de que nada mais restava do passado, e imagina a vida que tinha diante de si a contemplar "o filho, morrendo minuto por minuto, ameaçado de trevas, ameaçado da imobilidade definitiva, ameaçado de tudo, mas vivo, vivo sempre". Nesse instante de desespero, fita uma imagem colocada na mesa de cabeceira:

Havia qualquer coisa de puro e de essencial naqueles olhos de vidro, qualquer coisa de paradoxal e humilde, que a fazia ver tudo agora sob uma luz nova, radiante, vinda do alto, que rompia em mil raios corruscantes, imensos, em 
uma explosão cegadora, que ultrapassava e se reconstituía além da tosca imagem, e enchia, através de tudo, o horizonte, e, para lá, todo o universo.

- A senhora nada sofrerá - continuou o médico, e não interrompera o que dizia nem uma vez, pois via que o rosto de Dodôte, apesar das pálpebras abaixadas, estava sereno, iluminado por dentro, por uma luz suave e tranqüila. - Mas o menino... viverá muito tempo!

- Não sofrerei... não sofrerei. - Disse Dodôte, muito baixinho, com infinita doçura. - Meu filho será o meu repouso! (p. 384)

Ao término do romance se explicita o sentido de seu título. Ao tomar conhecimento da doença degenerativa congênita do filho, Dodôte num primeiro momento está prestes a entrar em desespero. Ao fitar os olhos de vidro daquela imagem, provavelmente tão tosca quanto aquelas que testemunharam a união entre o narradorprotagonista de Fronteira e Maria Santa, dá-se conta instantaneamente de que a doença do filho poderia representar, ao contrário, a sua salvação. Quanto a que tipo de salvação seria essa, creio que poderá haver diversas interpretações de acordo com o leitor. Certamente um intérprete católico terá a sua leitura influenciada por essa crença. Acredito que, à medida que não se desgarre muito do texto, seja possível propor uma leitura que não inviabiliza outras interpretações que possam se sobrepor a ela. Nessa leitura, a salvação seria o repouso de si mesmo, da hipertrofia da interioridade, que acaba por inviabilizar qualquer descanso, do pensamento ininterrupto sobre si próprio, que impede o sujeito de simplesmente viver. Passando a ter, a partir do nascimento do filho, sobretudo de um filho que irá inspirar muito mais cuidados e atenção do que uma criança normal, uma fonte de preocupação constante que possa desviar o pensamento de si mesma, Dodôte imagina que poderá conseguir viver para ele naturalmente, como as aranhas, que se ocupam tão-somente em se alimentar e em tecer o fio de suas existências, como tudo o que vive na natureza e não pensa. Essa dedicação ao outro parece ser o meio pelo qual é eventualmente possível descansar dos pensamentos incessantes, excetuando-se obviamente a morte e o retorno à matéria inorgânica, bem como os momentos fugazes que a ela se assemelham: o sono, o delírio, a união sexual. O papel da imagem posta sobre a cabeceira, na cena final do romance, não me parece deixar dúvidas: é a arte, mesmo imperfeita ou exatamente na medida de suas imperfeições, outro desses meios, tanto para o artista que se entrega ao trabalho de criação, como para aquele que vicariamente dele participa. Em alguma medida, a arte se 
aproximaria assim da natureza e seria igualmente círculo mágico, que desperta e provoca o encantamento, e que participa da morte e da dissolução. 


\section{DAS MONTANHAS DE ITABIRA AO VALE DO PARAÍBA: O NEGRO EM PRIMEIRO PLANO}

$O$ art. $6^{o}$, parágrafo 1 da Constituição não reconheceu como cidadãos brasileiros os escravos, enquanto escravos, embora nascidos no Brasil, e, certamente, não podia nem devia reconhecê-los como tais, porque os escravos são antes uma propriedade, embora de natureza especial, do que pessoas no gozo de seus direitos e, assim, não podem ser membros da sociedade civil e, menos, da sociedade política; o declará-los cidadãos valeria o mesmo que libertá-los. Ora, daí deduziremos uma primeira conseqüência e é que, qualquer que seja o lugar do nascimento, o escravo enquanto escravo não tem pátria nem nacionalidade; sua naturalidade é indiferente em relação à sociedade civil ou política, pois que ele não é membro dela.

Pimenta Bueno (cit. por Boris Fausto)

... tirou do bolso a sobrecarta fechada com as obreias da fazenda, com as armas e sua divisa: Spes et labor.

Cornélio Penna 


\subsection{A figuração do negro de Fronteira a Repouso}

O grande risco de acompanhar a obra acabada de um escritor no sentido cronológico em busca de permanências e mudanças, grandes ou pequenas, é levar a crer que o percurso teria se dado de modo inteiramente racional e consciente, que o caminho percorrido não poderia ter se dado de outro modo e que ele se deu - e que sempre se dá - no sentido do aprimoramento, da sofisticação da técnica e da criação literárias. Se essa evolução realmente sempre se desse, a primeira obra seria invariavelmente a mais fraca e a última, a melhor. Não é preciso insistir muito no fato de que com frequiência deparamos exatamente com o contrário disso, escritores cuja obra-prima é a obra de estréia e que, a despeito de diversas tentativas, nunca mais conseguem repetir o êxito. Em relação ao próprio Cornélio, vimos que Fronteira é muito superior a Dois romances de Nico Horta e, para muitos, a Repouso. Quanto à inevitabilidade do percurso, pode-se dizer com segurança que se trata de uma espécie de ilusão de ótica provocada pelo ponto de vista a partir do qual olhamos para a obra e a história do escritor. Com a obra acabada, morto o escritor, escrita a sua biografia, publicadas as versões definitivas de seus livros, nos debruçamos sobre eles, e se torna inevitável a descoberta de antecipações e retomadas, temas que se repetem e se ampliam, procedimentos apenas insinuados que se transformam em características distintivas do autor. Todavia, não é este o problema, mas sim pensar que tudo isso foi inevitável. Acontece aqui o mesmo que com a psicanálise. O próprio Freud chegou a reconhecer que, se a experiência da análise podia levar ao passado mais remoto por meio da lembrança gradativa dos acontecimentos, que seriam como os elos de uma corrente, na ordem inversa de sua real sucessão, em que estariam ligados por uma relação de causa e efeito, seria impossível obter qualquer informação segura se se quisesse empreender o movimento contrário, isto é, se se tentasse a partir de um primeiro episódio descobrir como se daria o seu desenrolar, quais os episódios que necessariamente se sucederiam a ele ${ }^{1}$. Não é muito

\footnotetext{
1 "Enquanto perseguimos o desenvolvimento a partir de seu resultado final, ascendendo pois a isso, o que se constitui aos nossos olhos é uma conexão sem lacunas, e ficamos com a impressão de estarmos completamente satisfeitos, até mesmo de termos sido exaustivos. Mas, se tomamos a via inversa, se partimos dos pressupostos descobertos pela análise e os seguimos até o seu resultado, então a impressão de um encadeamento necessário, e de que seria impossível determinar de outra maneira, nos abandona completamente. Notamos logo que teria podido resultar disso igualmente alguma outra coisa, e esse outro resultado poderíamos do mesmo modo compreendê-lo e explicá-lo. A síntese não é pois tão satisfatória como a análise ; em outros termos, não estamos na condição, a partir do conhecimento dos pressupostos, de prever a natureza do resultado." ("Sur la psychogenèse d'un cas d'homosexualité féminine”, apud Joel Birman, Estilo e modernidade em psicanálise, p. 50.)
} 
diferente o modo como Ilya Prigogine ${ }^{2}$ vê a seta do tempo em seus estudos sobre a teoria da complexidade. As bifurcações representam os momentos em que duas direções se apresentaram diante de um determinado fenômeno. Escolhido um caminho, outra bifurcação se apresentará à frente e uma outra escolha irá se dar e assim sucessivamente. Se, partindo de um certo momento, é possível olhar para o passado e ver as escolhas que foram feitas e o percurso seguido até ele, é impossível projetar quais serão as escolhas futuras a não ser num nível probabilístico. Do mesmo modo, não se pode acreditar que teriam sido inevitáveis as escolhas feitas no passado e nem que determinados caminhos devam ter sido necessariamente percorridos - ao contrário disso, o acaso desempenha aqui um papel fundamental. Por fim, no que se refere ao artista, se é impossível negar o papel fundamental da consciência e da razão nas escolhas feitas, não se pode desconsiderar o papel do acaso, do inconsciente, do que se dá mais no campo da sensibilidade e do sentimento do que na esfera da razão, sem deixar de notar a impossibilidade de qualquer separação muito nítida entre esses campos e esferas e o papel que teriam desempenhado em tudo o que é criação humana.

O intuito dessas considerações é relativizar o que possa ser visto como evolução algo determinista e mecânica na apresentação do caminho trilhado por Cornélio Penna ao longo da publicação de sua obra e do tratamento de alguns temas e do uso de alguns procedimentos recorrentes de modo cada vez mais complexo e seguro, e também adiantar os limites desta abordagem, que se propõe a ver o tratamento da temática relativa ao negro em Repouso, depois de seu surgimento em Fronteira e reaparição, com mais força, em Dois romances de Nico Horta, como um prenúncio e ao mesmo tempo condição para o aprofundamento que ele terá em A menina morta.

Em Nico Horta, vimos como essa temática ganha já destaque. Antes mesmo do episódio em que Nico se recorda da violência que ele, criança, empregara contra a mamãe-negra, o narrador já se referira às lembranças da própria escrava:

Na cozinha, a velha negra que os criara e ouvia tudo com a resignação fatal de sua raça, pois ela sabia que dos senhores se devia ter medo sempre, um terror sagrado que guardava no fundo de seu coração de mãe humilde e forte, iniciada desde a infância nos mistérios e castigos da família de seus donos.

\footnotetext{
${ }^{2}$ V., entre outras obras, Ilya Prigogine \& Isabelle Stengers, La nouvelle alliance.
} 
- Negrinha, reza direito! - dizia-lhe secamente a sinhá-moça daquele tempo, dando-lhe forte pancada na cabeça, quando não conseguia fazer sair da garganta o erre de fruto ou de espírito. (Dois romances de Nico Horta, p. 62)

Depois dessa recordação, surge a lembrança dos eventuais pontapés que levava dos meninos enquanto tirava-lhes os sapatos e as meias, quando procurava disfarçar o prazer de acariciar aqueles "meninos-deuses".

Parece-me que em Repouso as coisas tornam-se ainda mais complexas. Em primeiro lugar, há no terceiro romance de Cornélio Penna inúmeros negros que viveram a experiência da escravidão e vivem agora o lado positivo e o negativo da libertação, bem como a dificuldade ou a impossibilidade de se libertarem de fato. Um desses negros é o pajem de José. Quando Dodôte chega à cidade para o enterro do irmão, vai até o quintal e traz de lá "o criado negro e velho que se ocultara para chorar". E Dodôte acredita que "todo o afeto, a bondade, o sentido de proteção de que [o irmão] era capaz se concentrara naquele filho de escravos, seu pajem de menino" (p. 60). Um outro antigo escravo a que se faz menção é Vicente, um "preto velho" que fora pajem da mãe de Dodôte, "e que agora vivia abandonado do outro lado da cidade, lá no Bongue, vivendo sabe Deus como...” (p. 230). Outro desses pretos velhos continua a serviço de D. Rita, juntamente com as criadas, e é ele que vem receber a comitiva que retorna do Jirau com os animais carregados de documentos e da prataria. Nada mais é dito sobre todos esses personagens, mas para Vicente não é difícil imaginar que a libertação e a decadência da família a que pertencia como propriedade no passado, o que quer que tenha ocorrido primeiro, não tiveram bom resultado, restando apenas o abandono e a miséria. Há, por outro lado, a antiga ama de leite de Urbano, "agora cheia de filhos e viúva", de quem não é dito que fosse ou tivesse sido uma escrava, mas que é descrita como uma "cabocla gorda e ainda moça". Ela vai para a botica a pedido da avó de Urbano, agora "como uma simples mercenária", e não nutre por ele qualquer sentimento mais profundo: "olhava para Urbano com olhos espantados e risonhos, como se achasse ridículo ter de considerá-lo seu filho de leite, sem ter por ele a menor curiosidade e estima". (p. 157) Mas havia ainda a lembrança de Urbano de sua pobre mãe preta e das "instruções que lhe dava [sobre as orações que devia fazer], carinhosamente, em sua meia língua, e de acordo com a liturgia que conseguira aprender ao acaso" (p. 175), e era de acordo com essas instruções que um Urbano de meia-idade ainda rezava. Vê-se aqui como são fortes os vínculos entre o desenvolvimento do sujeito e sua criação por 
escravos, que não recebiam qualquer educação formal, que mal sabiam falar a língua dos senhores brancos ${ }^{3}$, que aprendiam a religião de oitiva e sem qualquer orientação por parte do clero, e assim a repassavam aos seus filhos de leite, certamente misturada aos credos inteiramente diversos recebidos de seus ancestrais.

Em nenhuma dessas relações os vínculos entre um branco e sua ama negra são tão fortes como naquela existente entre Dodôte e Chica ${ }^{4}$, assim como nenhum personagem negro até então ganhara tamanho destaque na obra de Cornélio Penna, que escreve pela primeira vez um diálogo propriamente dito, e mesmo relativamente longo, em que um antigo escravo participa de modo tão ativo, que é aquele que se dá entre Chica e Dodôte no capítulo 31. E no capítulo 63, durante a doença e convalescença de Dodôte, esta rememora a sua infância e a presença nela da ama, e o modo como é vista a escrava não me parece ser facilmente encontrável em outros escritores:

De muito acima, de suas recordações mais antigas, quando ainda menina e dominada pela personalidade tão complexa em sua primitividade, tão singular pelo estreito consórcio de bom senso e mentira que caracterizava a sua velha mãe preta, vinha o desmentido de sua ilusão, da viagem e do rapto. (p. 329, grifo meu)

A expressão paradoxal parece-me fazer muito mais justiça à escrava negra do que muitas afirmações que, sob aparência favorável, mal conseguem esconder a atitude de superior condescendência. Não há nenhum ganho em se deixar de usar a palavra primitivo, trocando-a por uma outra qualquer - diferente, mais próximo da natureza, mais simples -, se no fundo persiste a desconfiança sobre sua inferioridade. Ao afirmar, ao contrário, como é "complexa em sua primitividade" a personalidade da mãe preta, Cornélio reconhece que é a dela uma cultura muito diferente da do branco europeu, mas tão ou mais complexa do que ela ${ }^{5}$. Por outro lado, o "estreito consórcio de bom senso e mentira", que caracterizaria Chica, revela - como ficará ainda mais evidente em $A$ menina morta - a inteligência da escrava, pois, muito mais do que simples absurdo, a

\footnotetext{
3 "Negros boçais": foi só recentemente que vim a saber, devido a uma observação esclarecedora do prof. Hélio Guimarães, que assim eram chamados os negros recém-chegados da África e que não falavam a língua do país. Como ocorreu com o termo "bárbaro", utilizado pelos gregos para se referir aos povos que não falavam a língua grega, que acabou adquirindo um sentido muito pejorativo, "boçal" passou a significar "estúpido" ou "grosseiro". (Aurélio Buarque de Holanda Ferreira, Pequeno Dicionário Brasileiro de Língua Portuguesa)

${ }^{4}$ Chica parece ter existido de fato e com este mesmo nome, tendo sido mencionada num depoimento do escritor sobre o contexto da composição de Fronteira como "a nossa velha ama".

${ }^{5}$ V. cap. 4.
} 
mentira tem um sentido e um uso muito precisos. A mentira a que aqui se faz alusão liga-se à imaginação da Dodôte adulta, cuja origem, porém, muito provavelmente se encontra na infância e nos contos que a menina ouvia da mamãe preta a respeito de uma carruagem fantasmagórica que circulava à noite pelas ruas escuras da cidade, e cujos guizos as crianças certamente acabavam por ouvir, em que ela agora pensa viria o anjo companheiro que devia buscá-la. No entanto, sabia já que não era ele na carruagem, pois que esta

trazia o corpo da senhora assassinada pelas escravas, e aquele corpo devia ser conduzido assim, eternamente, sem dilações. A morta devia estar ainda com o longo vestido branco, com três ordens de babados nas saias de tarlatana, presos com laços de seda alvíssima, mas todo manchado de sangue vivo e palpitante, que não devia secar nunca, enquanto não se cumprisse a maldição que as negras em revolta tinham lançado sobre ela. (p. 329)

As lembranças retornam diversas vezes enquanto Dodôte alterna momentos em que se apresenta restabelecida com ocasiões em que a morte parece inevitável. E entre uns e outras, Chica é uma presença constante a seu lado, a não ser quando outras atividades exigem a sua atenção, como no dia em que "tinha uma enorme tachada de sabão de cinza a terminar, e devia mexer o caldo escuro e de acre aroma, que fervia sobre a trempe, instalada a um canto, no atijolado". (p. 335) Num desses momentos de rememoração, Dodôte recorda-se do caminho que percorria entre a propriedade dos avós e a fazenda da tia, há muito tempo falecida. Ficavam muito próximas uma da outra, e Dodôte lembrava-se do pequeno vale e da colina que ali havia, "em cujo tope se erguia um quadrado de muros gretados, que cercava as árvores crescidas dentro dele, muito grandes e copadas, as únicas naqueles pastos”. Vendo-o, a criança imagina que lá ficava "o jardim misterioso e escondido da princesa, da menina de cabelos de ouro puro e de olhos cor do céu dos contos de Chica". Mas um dia Chica a levara consigo até o vale e, depois de recolher algumas plantas para fazer remédios caseiros, ajoelhara-se diante do que restava do portão que fechava aquela recinto murado e se pusera a chorar. Mesmo sem que Chica revelasse a que se deviam a reza e o choro, a menina sabia que aqueles sonhos imaginários que transformavam a paisagem daquela colina no jardim de uma princesa nunca mais seriam os mesmos. Um dia, porém, acaba por descobrir a verdade: 
Nunca perguntara nada a ninguém, mas, uma palavra dita por sua avó a fizera compreender que se tratava do cemitério dos escravos, mandado fazer pelo primeiro senhor daquelas terras. Chica devia ter, nele enterrados, os seus pais africanos, e muitos outros de sua raça, mas até hoje não sabia se isso era certo. (p. 345-6)

Entre os capítulos 16 e 17, Dodôte circula pelo cemitério da cidade, também localizado - como quase sempre se dá nas cidades antigas - na parte mais alta. Sem que nada seja dito de modo explícito, vemos que ela caminha dos túmulos e dos monumentos funerários grandiosos, colocados na entrada do cemitério, feitos de mármore, com as letras do nome daqueles que ali estavam enterrados, já muito deteriorados pela ação do tempo e pelo abandono, mas revelando ainda toda a riqueza e o poder que detinham em vida, passando em seguida pelos monumentos fúnebres mais simples, apenas cercados por correntes de ferro, presas a argolas enferrujadas, até finalmente chegar perto da

parte mais larga do cemitério, onde surgiam, entre pobres flores malcuidadas, amarelecidas e requeimadas pelo sol do alto, as pedras irregulares dos tristes túmulos rasos. As cruzes se desfaziam, e o granito se abria em fendas, desmanchando-se. Caíam aos poucos, e perdiam-se com o fustigar do tempo e das intempéries. (p. 85, grifo meu)

Só agora, perto já do final do romance, vemos que essa representação da sociedade por meio da descrição do cemitério e dos túmulos, para onde todos um dia se encaminham, ainda não estava completa. Faltavam os escravos, que não tinham lugar no cemitério dos brancos, pois nem na morte podiam a eles se misturar, por mais que vivessem, como vimos, numa intimidade que dificilmente podia ser encontrada entre dois brancos, mesmo que fossem mãe e filho, e sequer tinham direito aos túmulos rasos destinados aos pobres. Se o número de pobres era grande e muito maior do que aquele dos medianamente ricos e, sobretudo, dos muito ricos, como se pode notar na afirmação de que os túmulos pobres ficavam na parte mais larga do cemitério, o número de escravos 
devia ser ainda maior, e não é difícil imaginar as possíveis causas que os levavam àquele destino.

Para que o quadro fique completo, porém, devemos pensar na obra de Cornélio como um todo e, particularmente, em Fronteira, onde se mencionam aqueles que eram sepultados dentro das igrejas barrocas, provavelmente os ainda mais poderosos, influentes e ricos. Esse quadro tão revelador da sociedade brasileira, que cobre um largo período da nossa história, composto por cemitérios e túmulos, parecia pedir uma outra representação que mostrasse as relações entre brancos e negros de modo ainda mais complexo. Cornélio Penna poderia ter se decidido por não se lançar a ela e esse apelo restaria inútil. Mas ele decidiu-se a fazê-lo e pôde assim escrever a sua obra-prima, $A$ menina morta. 


\subsection{O escravo, o agregado, o proprietário e as meninas mortas}

A porta moveu-se devagarinho e alguém entrou de costas com dificuldade, como se trouxesse fardo muito grande e pesado, oculto ainda pelo balão e pelos babados negros que o enfeitavam. Afinal, sempre com grandes precauções voltou-se e Celestina e Sinhá Rola verificaram que era Dona Inacinha com grande tela nas mãos. Quando chegou perto do candeeiro que estava em cima do instrumento de música ela levantou o quadro nos braços, e puderam distinguir ser o retrato a óleo da menina morta, ainda reluzente de tinta úmida.

- Está muito bem feito - murmurou - tirei-o da sala de fora, onde o pintor o deixou e trouxe para cá para vocês verem.

As três agora de pé e reunidas em grupo ficaram a olhar comovidas a tela que colocaram sobre o consolo. Nela, estendido sobre a mesa, o corpinho da menina com vestido de brocado branco entretecido de flores de prata, destacava-se do fundo escuro, com a cabeça adornada de pequeninas rosas, levemente coloridas. Era simples e emocionante e dele se desprendia encanto muito sutil, de extraordinária paz, de vitória suave sobre a vida...

- Para dizer a verdade - segredou para as outras Dona Inacinha eu acho este quadro horrível de tristeza, e nem sei como tive coragem de segurar nele e trazê-lo para cá. Creio que não poderei levá-lo para a saleta onde o pintor o deixou, e com certeza o primo vai ficar zangado, pois foi ele quem mandou o artista executá-lo. (cap. 21, p. 108-9)

Em Fronteira, Cornélio Penna pendurara na parede da sala alguns quadros, e num deles estava pintado o retrato de Dona Maria Rosa, avó de Maria Santa. Durante uma conversa desta com o juiz, o narrador nota "a semelhança esquisita que havia entre a avó e a neta": "Sendo os seus traços tão diferentes, havia, entretanto, entre eles, uma concordância visível, mas inexplicável” (p. 42). Em Repouso, Dodôte, grávida e prestes a cair doente, caminha pela casa da avó, para onde retornara depois da morte de Urbano, e chega à sala de visitas, onde se senta no sofá para logo ficar com "a impressão de que alguém a olhava, na sombra, de que dois olhos a fixavam, implacáveis", até dar-se conta de que era o retrato de um dos velhos patriarcas, e é este o mote para que o narrador nos dê, em poucas palavras, mas com imagens de grande força e contundência, a história da origem, ascensão e queda inexorável da família: "o casarão que construíra, e seguira a traça da mansão, do casal longínquo, que não pudera esquecer, era agora a Santa Casa, e 
muitos dos que vinham de seu sangue nela se acolhiam como indigentes" (p. 338). Agora, n' A menina morta, o escritor-pintor traz um quadro para o centro do relato. Trata-se de uma obra que existiu de fato ${ }^{6}$ e que representava uma das tias bisavós de Cornélio Penna, morta em tenra infância. O curioso e até perturbador é que, em vez de pintar a menina viva e sorridente, por meio da utilização de fotografias, de sua descrição pelos pais ou parentes ou mesmo da imaginação do artista, para guardar uma lembrança dos momentos em que a família pôde tê-la feliz e cheia de vida em seu seio, o pintor por decisão própria ou por ter sido esta a encomenda - a representou exatamente como se encontrava pouco antes de ser colocada no pequeno caixão, estendida sobre a mesa, de olhos fechados, mãozinhas sobre o peito, vestido passado e engomado, a cabeça adornada com uma pequena coroa de rosas. Simone Rufinoni dá notícia de que era essa a "moda com que se eternizavam os 'anjinhos' no Brasil colônia"7 e acrescenta depois a observação, sagaz e verdadeira, de que deitada, no quadro, ela parece levitar. O fato de ter existência real não nos deve dizer menos sobre o escritor do que se ele o tivesse inventado. A verdadeira fixação que Cornélio Penna tinha pelo quadro, fazendo sempre questão de mostrá-lo aos poucos amigos que o visitavam, o zelo com que o guardou durante toda sua vida, as incontáveis vezes - é ele quem afirma - que o teria contemplado, as menções que fez a ele antes mesmo de começar a escrever o romance ${ }^{8}$ e a decisão de fazê-lo antes provavelmente de qualquer plano mais definido indicam a fundamental importância que o escritor atribuía a ele e nos compelem a indagar dos motivos que o levaram a isso. Os quadros de família certamente deviam exercer um enorme fascínio no escritor que fora um dia pintor, não só por isso, mas também e sobretudo porque se ligam, por um lado, à arte, à criação, e por outro, à memória, à preservação - indiscutivelmente, dois eixos fundamentais da obra corneliana. No caso da maior parte desses retratistas, é lícito pensar que esses dois campos não teriam recebido igual atenção, tendo o intuito de preservação da imagem quase sempre prevalecido sobre a criação artística. Mas é talvez por isso mesmo um excelente meio para a reflexão sobre questões como reprodução, cópia, representação, fidedignidade, verossimilhança. Assim: quanto mais ingênua reprodução da realidade, mais distante da

\footnotetext{
${ }^{6}$ Pode-se vê-la hoje, tal como descrita por Cornélio Penna, no Arquivo-Museu de Literatura Brasileira da Fundação Casa de Rui Barbosa.

${ }^{7}$ Favor e melancolia, p. 128.

8 "Os velhos momentos vividos em Pindamonhangaba, o sangue materno, as recordações, os sentimentos que me tinham embalado, sobrepujados mas não vencidos pela fôrça sôbre-humana de Itabira, vieram à tona, e vou escrever outro livro, que se chamará simplesmente A Menina Morta." (Ledo Ivo, "A vida misteriosa do romancista Cornélio Penna", p. LXVI.)
} 
verdadeira arte, e paradoxalmente mais distante ainda da realidade; e quanto mais desta se afaste, quanto maior a diferença em relação a ela, mais próxima da arte e da própria realidade. $\mathrm{O}$ fato é que em A menina morta o quadro aparece e desaparece em diversos momentos e acaba por "contracenar" de algum modo com outros personagens, tornando ainda mais complexas as relações entre realidade e imagem do que nos romances anteriores.

N'A menina morta irão se misturar: a figura da menina, seja na lembrança dos que com ela conviveram, seja na superfície da tela pintada; a de Carlota, que com a morte da irmã é trazida de volta da Corte para a fazenda por ordem paterna; e a imagem da mãe, com quem Carlota ficará cada vez mais parecida à medida que se aproximar o fim do romance. Assim, pode-se dizer que a menina morta não compõe isoladamente o tema central do romance. Ou, melhor dizendo, esse tema não se circunscreve à filha caçula do Comendador morta na infância, pois "a menina morta", título do livro, compreende uma pluralidade de sentidos: o primeiro remete obviamente a essa menina; o segundo, ao quadro que a representa; o terceiro, a Carlota, porque, ao retornar ao Grotão, acaba de algum modo assumindo o lugar da irmã mais nova para boa parte dos moradores, especialmente dos escravos, sendo mesmo muitas vezes confundida com $\mathrm{ela}^{9}$, mas, ainda mais importante do que isso, porque Carlota também se torna "a menina morta" na medida em que, ao tempo em que se dá o esfacelamento de sua família, descobre o horror da escravidão e da propriedade fundada na violência e no crime, por meio dos quais diversas gerações de sua família acumularam riqueza e poder e os transmitiram aos descendentes: "Envelhecera, e não estava mais ali a jovem que chegara do Colégio. Qualquer coisa de acerbo em sua boca, a sombra que agora velava os seus olhos, faziam dela outra mulher e a menina desaparecera irremediavelmente..." (p. 479, grifo meu). E é aqui que a Carlota que surge poderá ser associada à mãe.

Voltemos ao quadro e à cena em que ele pela primeira vez aparece no romance. Vem ainda úmido de tinta, resultado de o escritor ter-se atido estritamente a seu propósito de escrever um romance a partir do quadro que herdara da família. Não é por acaso que ele faz com que a sua entrada no romance, por assim dizer, se dê pelas mãos de Dona Inacinha, que o apresenta à sua irmã, Sinhá Rola, e a Celestina, sendo elas três

\footnotetext{
9 "Dona Inacinha estava tão absorvida que não distinguia mais para quem estava fazendo aquele trabalho e na verdade esperava a chegada da criança e não da jovem que viria da Corte... E a menina morta estava agora ao seu lado e sentiu suas mãos miúdas que puxavam suas vestes.” (p. 184) “- Ah, Nhanhã - disse Libânia por entre as lágrimas a the escorrerem agora dos olhos, mansamente, de forma tão passiva - eu... eu julguei... eu me lembrei da menina morta, pois me parecia ser ela a Nhanhãzinha de volta agora grande, moça e bonita...” (p. 265)
} 
agregadas da fazenda, três parentes pobres: as irmãs, da família do Comendador; Celestina, da de sua mulher. Como veremos, quase tanto quanto para os escravos, a menina tinha uma grande significação para essas mulheres, entre outras coisas porque todas podiam fazer delas o pensamento de Dona Inacinha de que "para a menina ela não era a parenta pobre e protegida, sempre pronta a dizer qualquer coisa que julgaria depois ácida e impertinente, em seus amargos exames de consciência...” Por ser criança, ela ainda não fazia distinção entre os proprietários de fato e aqueles que ali viviam de favor, e diante dela estes não precisavam ficar o tempo todo se policiando para não dizer o que não podia ou não devia ser dito, diante do risco de a qualquer momento perderem a proteção e o abrigo de que desfrutavam. No fragmento em epígrafe, é justamente esse receio que faz Dona Inacinha num primeiro momento elogiar o quadro, para depois segredar que na verdade o achara "horrível de tristeza". É também por isso que ela imagina, desconsolada, que o primo ficará zangado se não encontrar o quadro na saleta, pois a encomenda fora feita por ele.

Antes da entrada de Dona Inacinha, temos nessa sala de visitas uma espécie de cromo em que Sinhá Rola cantarola uma modinha e dedilha o acompanhamento ao clavicórdio, e Celestina, que ali chegara depois dela e se sentara procurando não fazer barulho, a observa sem ser notada. Intercalados por alguns versos da canção "Conselhos não valem, se fala o amor..." - o narrador descreve o ambiente de maneira minuciosa e plástica: o álbum de canções confeccionado sem nenhuma arte, o mármore negro do consolo, frio ao contato, em que Celestina apoiara a cabeça, o vestido de cassa branca com flores negras que Sinhá Rola vestia, cujos babados caíam sobre o tapete turco ali posto para os pés de quem estivesse ao instrumento, e assim por diante. Ao mesmo tempo, vão se revelando o estado de espírito das duas personagens, a melancolia e o pesar daquela que canta, o espanto da outra por ver o luto rompido e a tristeza que a vai contagiando. Tendo cessado a música, Sinhá Rola põe-se a chorar e Celestina se decide a abordá-la, iniciando-se então um diálogo cheio de lembranças e confissões. E é no exato momento em que aquela menciona o ódio que às vezes tem à irmã, que esta entra na sala com o quadro da menina morta nas mãos. Mais uma vez, a narração nos dá uma nítida imagem da cena: a porta que se abre devagarinho, a entrada de costas de D. Inácia, pois estava de mãos ocupadas, a dificuldade com que ela carrega o quadro, os babados do vestido que encobrem a visão dele, a aproximação do quadro ao candeeiro para que melhor o observassem. 


\section{"Crime" e castigo}

Essa verdadeira reconstituição de um passado já esquecido procurou dar conta exatamente do período e do lugar em que teria vivido a menina morta, para muito além da sala de visitas, como iremos ver. Ocorre que esse período foi a segunda metade do século XIX num momento em que não fora ainda abolida a escravidão, e o lugar, uma grande propriedade rural voltada para a produção de café para o mercado externo com a utilização de mão-de-obra escrava. Ora, como vimos anteriormente, a figura do negro foi ganhando destaque cada vez maior na obra do escritor à medida que publicava um novo romance. Assim, o desejo de escrever sobre o quadro parece ter vindo inteiramente ao encontro do anseio ou da necessidade de dar ainda mais espaço em sua obra ao negro e ao escravo.

Desse modo, a escravidão não surge em A menina morta como painel ou pano de fundo de onde emergiria a história da filha de poderosos fazendeiros morta na infância ou ainda a história do desmantelamento dessa família e da decadência e ruína da grande propriedade produtora de café, mas ganha ao contrário o primeiro plano na narrativa, e dificilmente existirá romance brasileiro, antes ou depois de sua publicação, que tenha tratado desse tema na mesma extensão e profundidade ${ }^{10}$. Se não apresentasse qualquer outro ponto de interesse, restaria dificilmente compreensível - dada a importância fundamental do regime escravocrata em nossa história, com conseqüências que até hoje se fazem sentir - a relativa carência de estudos do romance seja por parte da crítica literária seja por parte de outras ciências como a História ou a Sociologia. A condição do negro no Brasil escravista, longe de se restringir a estereótipos e a preconceitos, é dramatizada no romance de modo a fazer jus à sua grande complexidade.

Cercadas pelos três homens as mulheres se uniram de novo, mas, pelos braços cruzados sobre o peito e pelas cabeças trêmulas e curvadas, via-se bem que não era mais um bloco que tomava o caminho de retorno. Cessara a vida que as unira, que fizera liga entre aqueles corpos negros agora envelhecidos e cansados... Em poucos momentos estavam de volta e foram conduzidas para a sala dos fundos, bem longe da residência onde se viam instrumentos de ferro enferrujado

\footnotetext{
${ }^{10}$ Apenas alguns meses depois da publicação do romance, Augusto Frederico Schmidt já escrevia: "Não se terá escrito sôbre a escravidão no Brasil, até hoje, nada mais impressionante do que alguns dos capitulos iniciais de A Menina Morta, o romance do Sr. Cornelio Penna, recentemente publicado. ("Nota preliminar", Romances completos, p. 723).
} 
espalhados por toda parte, ao lado de grandes peças de madeira carcomida jogadas ao acaso no chão duro e cortadas de forma estranha e sinistra. Das paredes mal caiadas onde se distinguiam em toda a volta, até a altura de homem, manchas escuras que formavam desenhos inexplicáveis com grandes borrifos espalhados em direções diversas, como se tivessem sido atirados com violência, pendiam muito seguros em grandes cunhas de pau, argolões também de ferro, brilhantes pelo uso, e algumas correntes de elos gastos e desenrolados até o solo...

As negras, logo que chegaram ao amplo terreiro, dirigiram-se para a porta dessa sala, aberta de par em par, e nela entraram sem murmúrio, sem que tivessem hesitado um só instante e ajuntaram-se no canto mais afastado, encolhidas e silenciosas. Seus olhos brilhavam e lançavam olhares mortais umas às outras, onde se liam acusações alucinadas, ferozes e sem perdão, e os grossos lábios arroxeados tremiam, agitados por mudas maldições. Os corpos se tocavam, e o cheiro que deles se desprendia era sufocante, acre, mas eram inimigas implacáveis as carnes que se uniam, e as almas entravam em guerra de morte. Muitas prometiam a si mesmas sangrentas vinganças e fariam todo o mal possível às companheiras que ali estavam, inermes e transidas como elas próprias. [...]

$\mathrm{O}$ feitor com uma praga gritou-lhes qualquer coisa que não entenderam. Entretanto já conheciam o que era, puseram-se todas no meio da grande quadra, elas mesmas desprenderam as pesadas camisas que lhes cobriam os bustos de formas opulentas e exageradas, e ficaram nuas até a cintura. Sabiam que não podiam receber palmatoadas como as outras porque então não poderiam lavar a roupa naquele dia, pois ficariam com as mãos inchadas e sangrentas... e também não queriam rasgar os vestidos que tinham de chegar até o dia de festa próxima, quando seriam feitas novas distribuições!

As portas já haviam sido fechadas e dentro em pouco gritos selvagens, ulos e súplicas gaguejadas, vieram lá de dentro mas perderam-se no terreiro imenso, e eram logo abafadas por ameaças ditas em tom surdo para que os ecos não chegassem até a residência, àquela hora ainda envolta em sombras e serenidade... mas, se chegassem até lá, poderiam ouvir que soluçavam:

- Sinhazinha! Sinhazinha! (A menina morta, cap.16, p. 78-9)

O que é narrado aqui é um movimento de fluxo e refluxo, de atração e repulsa, de união das escravas, que vislumbram na junção de forças a possibilidade de sucesso na realização de uma ação temerária, mas que, perseguidas e alcançadas por apenas três homens, entram rapidamente em processo de conflito e dissolução, desistem do que 
intentavam e, conduzidas à sala dos suplícios, submetem-se passivamente aos castigos, que surgem como inevitáveis e mesmo procedentes, e que não podem ser aplicados à custa de um dia de trabalho ou das vestimentas grosseiras que cobrem seus corpos. A desproporção entre o castigo terrível, sugerido no despir dos corpos da cintura para cima e nos gritos e nas súplicas, e a ação a que mal puderam dar início, a visita ao túmulo da menina morta na igreja de Porto Novo sem autorização superior, expõe o absurdo e a desumanidade da escravidão. As surdas ameaças trocadas entre as escravas revelam a impossibilidade de desforra contra seus algozes e a inflexão da violência, a mover-se inesgotável dentro de seu circuito, que irá se dirigir agora contra aquelas que já eram vítimas e provavelmente as mais indefesas dentre elas. Não se trata apenas de violência. O despir das camisas e a exibição dos "bustos de formas opulentas e exageradas" devia atiçar o desejo dos feitores e a mistura entre violência e erotismo, com os diversos graus de sadismo e masoquismo que estão sempre de algum modo presentes onde aquele par se encontra, não seria certamente um componente menor nessas relações. Embora reste apenas discretamente sugerida, há nesse mesmo episódio uma outra sugestão mais forte da mistura entre opressão e sexo ou, para dizer de modo mais específico, entre opressão e obtenção de favores sexuais:

... não tinham sido até aquela hora abertas as portas do quadrado e estavam prisioneiras. Alguém dissera que viria abri-las bem cedo e cobrara de antemão o preço dessa promessa, porém tardava, e nenhuma delas ousava reclamar. Olhavam com inquietude para as janelas da habitação de dentro que permaneciam cerradas e nela reinava silêncio completo; sendo ele celibatário devia aproveitar os últimos momentos de repouso que ainda tinha, pois...

Finalmente, um dos homens livres passou por elas sem olhá-las e foi até a porta que dava para o pequeno pátio da entrada fechada por simples porteira, e abriu-a sem ruído com certo jeito de cumplicidade e de mistério. (p. 75-6)

É possível pensar em outras moedas de troca, mas o duplo fato de se tratar de um homem livre e celibatário e de terem as escravas - as "negras solteiras" - tão pouco para oferecer além do próprio corpo leva-nos à desconfiança de que muito provavelmente foi por terem-no franqueado ao "feitor de dentro" que puderam ver franqueada a passagem que as levaria a Porto Novo, à igreja e ao túmulo da menina. Como pagaram adiantado e como o plano foi um inteiro fracasso, tiveram ainda que arcar com as chibatadas nas 
costas e quem sabe se não com o resultado daquela entrega a se materializar no futuro nascimento de mais um mestiço entre os tantos que existiam naquela grande propriedade e que constituem personagens do romance, como Libânia e as outras "mulatinhas de dentro".

Embora ainda não tenhamos aqui a questão em toda a sua complexidade, o que só vai ser dado pelo conjunto do livro, sobretudo na abordagem dos diversos casos singulares, vemos encenada nesse capítulo, curto como praticamente todos os 125 capítulos do romance, a realidade monstruosa do sistema escravocrata, o preço altíssimo que os escravos têm de pagar por intentarem a realização de anelos muitas vezes banais e inofensivos, e em diversas ocasiões sem conseguirem mesmo a sua obtenção e tendo como resultado de seu "atrevimento" os castigos mais cruéis. A fragilidade de sua posição fazia ainda com que o pouco da vingança que podiam perpetrar fosse voltada contra outros escravos como eles próprios. As tentativas de união, por seu turno, quando fracassadas, eram freqüentemente outros tantos motivos para o aumento da cisão e da desconfiança entre eles, fortalecendo ainda mais o opressor por meio da divisão entre os que eram oprimidos. O sexo era certamente um meio de obtenção de favores e privilégios, longe, porém, naquela condição, de garantir o cumprimento do acordo ou da promessa feita. É de certo modo o mesmo o caso do recebimento de outros benefícios, ainda quando não fossem sustados por qualquer motivo, como aqueles dispensados pela menina, que durante a distribuição de chapinhas de metal pelo senhor Justino, prêmio para os escravos que colhiam além da tarefa comum, furtava algumas delas e as entregava às negras, que lhe agradeciam de joelhos e "arriscavam assim fazer com que os encarregados da fiscalização percebessem a fraude". Ninguém certamente faria nada contra isso, pois a "Nhanhãzinha tudo podia dispor", mas é durante uma visita ao cômodo dos suplícios que Carlota, ao ver os negros no tronco, percebe o custo dessa atitude desinteressada da criança. A contrapartida de qualquer benefício que os escravos podiam receber era a privação da liberdade deles e a violência a que estavam sujeitos. Não pode existir caridade, favor, benevolência, compaixão, ou como quer que se denominem atitudes como essa da menina ou de qualquer homem livre no interior do sistema escravista, sem a contrapartida da opressão, da violência, da humilhação, da tortura. O benefício, mesmo que efetivamente recebido ou sobretudo quando efetivamente recebido, é assim tão parte do sistema quanto a punição. Desse modo, até mesmo o senhor, depois de passar pelos campos de trabalho, ordena sejam levados aos escravos "tonéis cheios de refresco feito com a fruta de época", que eles tomavam em 
largos goles de "canecas de folha-de-flandres": "Era a atenção solícita do Senhor, a presença paternal que os mantinha sempre em saúde, a fim de ser conseguido o rude vigor que se esperava deles.” (p.26)

Essa menção irônica do narrador remete à figura patriarcal do Comendador, aquele em nome de quem se concedem não apenas recompensas, como principalmente castigos os mais terríveis. Era casado com dona Mariana, em união que teria resultado de verdadeiro afeto e envolvera diferentes níveis de riqueza e poder. A família dele, a poderosa família Albernaz, era proprietária de uma extensão de terra tão grande que pôde permitir a sua divisão entre os dois filhos que deixou ao Comendador um latifúndio como o Grotão, no Vale do Paraíba, enquanto a família dela desfrutaria naquele tempo tão-somente de poder político. As diferenças entre essas duas famílias são entrevistas quase sempre no modo desdenhoso como Dona Virgínia, a parenta mais próxima do Comendador, se refere a Mariana e à sua família, e no menosprezo que faz questão de demonstrar em relação a Celestina. Com a acolhida da família de Mariana pelo avô do Comendador em sua propriedade - o que seria apenas para um pouso de uma noite acabou se estendendo por um ano -, os futuros cônjuges puderam viver juntos parte da infância, e deve datar desse período a aproximação amorosa e o projeto de virem um dia a se casar. Tiveram quatro filhos, dois rapazes e duas meninas. Algo, porém, teria ocorrido com o casal no período imediatamente anterior à morte da filha mais nova, e aqui, a despeito do encobertamento constante e da ausência de qualquer referência mais explícita, não me parece haver dúvidas de que se relacionaria de algum modo com o escravo Florêncio.

De repente, ouviram o estampido de um tiro de garrucha, das de boca-desino, que fez estremecer as vidraças e estourou muito perto em seus ouvidos, para logo tudo recair na calma assim interrompida. As senhoras ficaram imóveis, geladas, sem saberem o que se passava, pois nenhuma delas teve dúvidas de que fora mesmo um disparo de arma da casa. [...]

Foi quando viram o Senhor entrar no pátio, já apeado do cavalo, trazido pela rédea presa ao braço e dirigir-se diretamente à sala dos feitores, onde entrou com precipitação, e sentia-se implacável energia em seus gestos. Deixara sem prendê-la às argolas a sua montada, e o pobre animal percorrido por estremecimentos e arrepios ficou agitado a girar sobre si mesmo até que o pajem veio agarrá-lo e o levou para as cocheiras. [p. 188] 
Até o fim do capítulo 38 e o início do seguinte, o acontecimento a que se faz alusão no trecho transcrito é mantido em relativo suspense e, do mesmo modo que os agregados, o leitor se pergunta o que de fato teria ocorrido. Na metade do capítulo 39, por meio de Dona Inacinha, revela-se que o tiro ouvido no dia anterior fora disparado por Florêncio contra o Comendador, que só por pura sorte escapou de ser mortalmente atingido, tendo se abaixado para verificar qualquer problema na taramela da porteira no momento em que o tiro partia na sua direção. A perseguição ao escravo pelos capitãesdo-mato, por outros escravos e pelos cães - "verdadeiras feras" - havia começado logo depois da tentativa de assassinato, mas é só ao final do capítulo, quando se desenrolara boa parte da conversa entre Dona Inacinha, Sinhá Rola e Celestina sobre os acontecimentos recentes e misteriosos, que Balbina, escrava das irmãs solteironas, revela que Florêncio fora encontrado enforcado numa árvore.

A história do escravo só será contada no capítulo 50, por meio das recordações de Libânia. A mulata recorda-se que havia pedido à Senhora que mandasse fazer o casamento dela com Florêncio e não obtivera resposta alguma. Florêncio era também um mestiço, mas filho do dono de uma fazenda e da ama-de-leite da fazendeira:

O moço casara-se com vinte anos e a noiva fora para casa acompanhada da escrava que a criara. A mestiça parecia a verdadeira noiva, com seus trinta anos no apogeu, a verter sangue sob pele morena de três raças, com os olhos fulgurantes e a boca muito carnuda. Tinha sempre a expressão de quem interroga melancolicamente o mundo sobre seu destino malfadado, e punha em qualquer movimento de seu corpo quente toda a flexibilidade dos gatos selvagens, e o odor desprendido de seus cabelos era poderosa evocação das florestas fecundas. (p. 235)

Essa escrava assim figurada com tamanha sensualidade teria praticamente tomado o lugar da mulher do fazendeiro, sujeita desde então a toda sorte de humilhações por parte dos amantes. A vingança, que por qualquer motivo não pudera realizar diretamente, voltou-a contra o filho deles: com a morte de ambos, que haviam se esquecido de libertá-lo, a fazendeira vendeu Florêncio como escravo ao Comendador, que era mesmo amigo e parente do fazendeiro falecido. Posto a trabalhar como campeiro, era tratado do mesmo modo que os outros escravos, mas vivia "inquieto e revoltado", sem estabelecer qualquer ligação mais profunda com eles, estando sempre isolado e mostrando-se muito altivo e superior: "viam passar [...] a silhueta forte e altiva do campeiro que gingava um 
pouco e tinha o passo lento dos homens robustos..." Não há descrição mais extensa de Florêncio do que essa, sendo de se supor que herdara boa parte da beleza da mãe, pois não apenas Libânia desejara casar-se com ele, como é dito pela encarregada das mucamas da cozinha que todas estavam "furiosas porque ele nunca quis nem sequer olhar para nenhuma, apesar das provocações..."

Nesse contexto, como nada é dito sobre a motivação do atentado, podemos apenas especular sobre ela. A primeira possibilidade é o escravo - sobretudo um que, orgulhoso e altivo, se sabe descendente de um proprietário de terras - que se quer vingar daquele que o escravizou e que em nenhum momento levou em consideração a sua origem, mesmo tendo sido amigo e parente de seu pai. Essa hipótese parece mais consistente que uma outra que procurasse descobrir no ato individual o interesse maior da coletividade, a tentativa de eliminação do proprietário como vislumbre da liberdade de todos os escravos, pois, para dizer uma vez mais, Florêncio não só não demonstrava sentir-se parte desse grupo como não buscava estabelecer com ele qualquer tipo de vínculo ou ligação mais estreita e solidária. Ademais, devia saber que o assassinato do proprietário não revoga a condição de escravo, podendo ao contrário desencadear uma repressão que a torne ainda mais sofrida e desesperadora. Sem descartar aquela primeira hipótese, e sem mesmo poder recusar de todo esta segunda, em função da ausência na narrativa de elementos para assim proceder, acredito numa outra possibilidade que poderia ampliar a compreensão de muitos aspectos no interior do romance e que demonstraria uma tremenda coragem por parte do escritor ao abordar tema tão candente, mesmo que de forma velada: a possível existência de uma relação amorosa entre dona Mariana e Florêncio, qualquer que seja o nível em que ela tenha se dado ${ }^{11}$.

Somente um acontecimento dessa gravidade poderia levar o casal a conceder tão pouca atenção às cerimônias que envolvem o velório e o enterro da própria filha ${ }^{12}$, já que em outros momentos tanto marido como mulher não deixam de demonstrar o amor que a ela dedicavam e o quanto sofriam em razão de sua perda. Há nesse sentido enorme contraste com o envolvimento nessas exéquias de diversos personagens, de escravos a agregados, que não cumprem essas tarefas como se fora uma obrigação, o

\footnotetext{
${ }^{11}$ Josalba Fabiana dos Santos entreviu essa possibilidade: "A aproximação entre eles [Dona Mariana e Florêncio] poderia ser amorosa ou sexual, o que geraria a necessidade de afastar o dono do Grotão". (Fronteiras da nação em Cornélio Penna, p. 21.)

${ }^{12}$ Libânia conta para Carlota que, à medida que a menina crescia, todas as atenções se voltavam para ela, o que fez com que ninguém notasse "a mudança que se operava rapidamente na vida dos senhores" e que Dona Mariana, além de tornar-se cada vez mais silenciosa e de retirar-se do governo da casa, começou "até mesmo a mostrar-se indiferente para com a menina..." (p. 437)
} 
que corresponde à tristeza e ao sofrimento diante da morte da menina. A escrava Lucinda e a governante alemã, senhora Luísa, preparam os trajes delicados com que a menina será enterrada; José Carapina, o escravo carpinteiro, com lágrimas nos olhos que não consegue fazer estancar, confecciona o pequeno caixão em que repousará o corpinho infantil e delicado; Bruno, o pajem do senhor, imerso em lembranças da menina, prepara a parelha em que iria buscar o padre para realizar as cerimônias fúnebres; Celestina, a parenta pobre da senhora, e Dona Virgínia, a parenta mais próxima do senhor, ambas agregadas, com lágrimas nos olhos, dão banho, perfumam e preparam o corpinho da menina para o enterro. Contudo, a despeito de todo esse envolvimento, e embora transpareça em primeiro lugar, nesses episódios, o carinho e o afeto que todos, sem distinção de classe ou posição no interior daquele grupo social, parecem nutrir pela menina morta, o leitor não deve deixar de observar que esse sentimento absolutamente não irmana aqueles que sofrem. Por mais afetados que estejam pelo triste acontecimento, as relações em geral não chegam nem mesmo a um provisório apaziguamento ainda quando se entregam aos preparativos para o enterro da menina. Dona Frau faz questão de manter a superioridade sobre a escrava; o escravo carpinteiro não deixa de lado a antipatia pelo negrinho Tição; Bruno fica agastado ao receber ordens de quem talvez não tivesse autoridade para mandar; e Dona Virgínia não consegue reprimir um riso de desdém ao ser chamada prima por Celestina. Penso que temos aqui um forte motivo para colocarmos já sob suspeita qualquer associação direta e inequívoca entre a figura da menina e a redenção, o apaziguamento ou a suavização das relações no interior do sistema escravocrata ${ }^{13}$. Nem mesmo a sua morte pôde fazer cessar, momentaneamente que fosse, os conflitos e os embates que caracterizavam as relações entre os moradores da fazenda. A violência, que em nenhuma circunstância pode ser separada da dominação sobre o escravo, infiltra-se em todas as relações, entre os próprios familiares, entre os agregados, entre os empregados livres e entre os escravos, e praticamente nada obtém amenizá-la. Isso absolutamente não significa que o sentimento de todos com relação à menina fosse falso. É exatamente por ser verdadeiro, seja por se tratar de uma criança encantadora em si mesma, seja por ainda não fazer diferença entre os habitantes da fazenda em função de sua posição, seja por concentrar em si a imagem de pureza e bondade que muitas vezes são associadas às crianças,

13 Depois de observação inteiramente acertada sobre A menina morta (cf. nota anterior), Augusto Frederico Schmidt descreve a menina como "uma espécie de 'anjo', desarmando com a sua força a guerra das raças”, o que já foi devidamente contestado por Luiz Costa Lima na obra mais de uma vez mencionada. 
embora saibamos o quanto há nisso de abstração ou mesmo de falsificação da realidade, seja finalmente por terem feito dela o centro das atenções de toda a propriedade, vestida e cercada de cuidados como se fosse uma espécie de fadinha encantada, a menina parecia despertar em todos os que conviviam com ela - especialmente nos escravos sentimentos de afeto e ternura. Mas, não fosse a morte, ela iria crescer, e com o tempo o encanto iria diminuindo, como acontece com a infância em geral, até que, no lugar da menina graciosa e delicada, surgisse a proprietária de terras e de escravos orgulhosa e distante.

Mas veio a morte e nenhum dos pais sequer comparece à sala onde ela estava sendo velada, assim como não acompanham o cortejo até a igreja onde seria enterrada. Quanto ao Comendador, não deixa mesmo de percorrer a fazenda como diariamente o fazia para acompanhar o trabalho junto aos cafezais. Apenas D. Virgínia e Celestina conduzem o caixãozinho no colo, dentro do carro, numa situação extremamente desconfortável. Alguns vizinhos e conhecidos que seguiam o carro funerário, ao serem informados de que a balsa não poderia naquele dia levar mais de uma carruagem por vez, desistem de acompanhar o cortejo e não deixam de expressar, por meio do trintanário enviado por D. Virgínia para repassar-lhes aquela informação, que o retorno era motivado principalmente pela decepção de não terem tido a quem dar os pêsames pela morte da "Nhanhã menina". O descompasso entre a riqueza e o poder da família daquela que morria tão nova e o amor e o afeto que todos indistintamente diziam ter por ela, de um lado, e a exigüidade da assistência e a precariedade de suas exéquias, de outro, ganha ainda maior realce quando aquele único carro chega à frente da igreja, e o caixãozinho, não tendo alças, quase vai ao chão no momento em que D. Virgínia e Celestina tentavam descê-lo, o que só não acontece porque, desesperadas, pedem o auxílio de Bruno e do trintanário.

Por outro lado, assim como pode ter chamado a atenção do leitor a alusão aos ouvidos moucos da senhora diante do pedido de Libânia em relação a Florêncio, não deve igualmente passar despercebido o pedido de Mariana ao padre Estevão para que fizesse "a encomendação do corpo de um d[os] escravos, falecido ontem". A motivação de um pedido tão ousado e provocativo durante o almoço e diante de todos os moradores não encontraria resposta apenas na atitude de desafio ao marido, ao desmentir publicamente a farsa do suicídio, já que um suicida não podia ser "encomendado" pelo padre, mas haveria nele - formulado por uma mulher com a saúde abalada e imersa num estado de grande alheamento - um desejo real de que Florêncio 
pudesse receber o conforto póstumo da religião. E é este um dos poucos momentos em que Dona Mariana participa das refeições na companhia dos outros moradores, pois passava a maior parte do tempo praticamente reclusa em seu quarto. Pouco tempo depois, é levada a abandonar a casa e processa-se então quase um apagamento de sua imagem, a ponto de Carlota não conseguir encontrar um único retrato da mãe depois de sua chegada à fazenda, naquilo que muito se assemelha à chamada morte em efígie.

Desse modo, a tentativa de assassinato do Comendador por Florêncio e a morte deste por enforcamento, já que a versão do suicídio parece não ter passado de um modo de manter as aparências para evitar maiores problemas ou explicações, encontrariam sua razão de ser na existência de um triângulo amoroso dos mais explosivos, embora quase tudo o que a ele se refira esteja como que mergulhado em sombras. Se assim for, o mistério em torno dos problemas que afetaram o casal desde o início do romance estaria ligado ao fato de que sobre um tabu como esse - um triângulo amoroso que tem num dos vértices um escravo e em outro, a mulher do proprietário - nada podia ser dito a não ser em voz baixa e em segredo. O que se desconfiava estar acontecendo na casa grande somente podia ser tratado pelos moradores por meio de suposições, boatos, indiretas e alusões veladas. E tenha sido essa ou não a intenção de Cornélio Penna, nós - leitores nos sentimos como se fôssemos agregados naquela casa enorme, mantidos na ignorância a respeito do que efetivamente ocorria com os senhores. A relativa incongruência entre o inexplicado e aparentemente inexplicável da vida do Comendador e de Mariana e a vida e as relações inteiramente transparentes de quase todos os outros personagens, sobretudo os agregados, encontraria também aí um sentido. Mas, mais do que isso - pois não pode ser descartada a possibilidade de o escritor ter intentado, com esse mistério, tão-somente a figuração do sem-sentido da vida e da falta de explicações e esclarecimentos para quase tudo na existência do homem, especialmente em meio a um regime pródigo na violência e no terror muitas vezes gratuitos e irracionais -, ao sugerir que possa ter acontecido algo mais sério entre Mariana e Florêncio, o enredo ganha uma densidade e complexidade inimagináveis ao dramatizar, de preferência aos casos mais óbvios de envolvimento entre homens brancos e escravas, quase sempre sem grandes consequiências pelo menos para os primeiros, um possível envolvimento amoroso entre uma mulher branca e casada com o proprietário todo-poderoso, majestosa e altiva, e um escravo mestiço, ainda que filho de um fazendeiro com uma mestiça, bem 
como as inescapáveis e catastróficas conseqüiências dessa aproximação ${ }^{14}$. Não me parece possível obter, porém, qualquer referência mais precisa sobre até que ponto essa relação teria chegado. Como quer que seja, ignoramos também o nível de conhecimento do Comendador sobre ela, bem como com que grau de certeza e de verdade. É claro que a execução de Florêncio pode ter sido motivada exclusivamente pelo atentado contra a vida do senhor. Mas não poderia ser também o merecido castigo pelo "crime" de se envolver com a senhora?

O escritor, contudo, não oferece ao leitor qualquer tipo de esclarecimento a respeito dessas questões por meio do narrador. Devia acaso fazê-lo? Ao contrário disso, fez da dúvida e do mistério elementos estruturantes da narrativa.

\section{Escravos de dentro e escravos do eito: singularidade e indistinção}

Grande parte da obra se articula em torno das relações entre senhores e escravos ou entre escravos e agregados. Referidos quase sempre de modo genérico quando o narrador trata do eito, os escravos surgem particularizados sobretudo, embora não apenas, quando se trata dos encarregados das tarefas domésticas ou relacionados mais

\footnotetext{
${ }^{14}$ Parece-me significativo que mesmo Gilberto Freyre, em Casa-grande e senzala, sempre muito aberto à percepção e ao reconhecimento de aspectos polêmicos, de expressão em geral interdita, notadamente as relações sexuais entre senhores brancos e escravas negras ou mulatas, sem deixar mesmo de ressaltar o sadismo e o masoquismo que costumavam caracterizar tais relações e de enfatizar as suas conseqüências, materializadas em um sem-número de mestiços nascidos nas grandes propriedades, que na maior parte das vezes nem por isso conseguiam escapar à condição de cativos, mesmo um autor como ele parece em mais de um momento ansioso por negar ou pelo menos fazer das possíveis relações entre mulheres brancas e escravos negros uma raridade quase inimaginável, a ponto de praticamente recusar algumas observações de um autor como Manuel Bonfim: "Verificaram-se, é certo, casos de irregularidades sexuais entres sinhá-donas e escravos. Um que teria ocorrido em Pernambuco nos meados do século passado e no seio de importante família, assegura-nos velho senhor de engenho ter visto registrado, em documento íntimo, com detalhes persuasivos. Mas nem as tradições rurais nem os relatos de estrangeiros merecedores de fé, nem as críticas, muitas vezes verdadeiros libelos, dos más-línguas desabusados da marca do Padre Lopes Gama, autorizam-nos a concluir com M. Bonfim, no seu América Latina: "não raro a sinhá-moça criada a roçar os mulecotes, entrega-se a eles, quando os nervos degenerados acordam em desejos irreprimíveis; então intervém a moral paterna: castre-se com uma faca mal-afiada o negro ou mulato, salga-se a ferida, enterram-no vivo depois. A rapariga, com um dote reforçado, casa com um primo pobre...' // Não que o despotismo paterno do tempo da escravidão nos pareça incapaz de malvadeza dessas, ou ainda piores; nem a sensibilidade muitas vezes mórbida das iaiás, de desejos ainda mais lúbricos. Mas o ambiente em que eram criadas nas casas-grandes dificilmente permitia aventuras tão arriscadas. O 'não raro' de M. Bonfim nos soa artificial ou pelo menos exagerado. Basta recordarmos o fato de que, durante o dia, a moça ou menina branca estava sempre sob as vistas de pessoa mais velha ou da mucama de confiança. Vigilância que se aguçava durante a noite. [...] Estas [aventuras] ocorreram, decerto; porém raramente." (p. 473) O principal argumento utilizado por G.Freyre pode ser facilmente contraditado: a ausência ou raridade de relatos, antes de indicar a inexistência dessas relações, pode indicar o tabu que pesava sobre elas. A justificativa para a raridade delas, a vigilância que era exercida sobre as iaiás, é de certo modo desmentida pelo próprio livro como um todo ao mostrar a proximidade (para não dizer a promiscuidade) em que senhores e escravos viviam.
} 
estreitamente aos homens livres. Assim, logo no início do livro, deparamos com a velha negra chamada Lucinda, a demonstrar um "gosto e bom-senso" que a governante alemã Dona Frau apenas confessava no íntimo, nunca o exprimindo nem o deixando transparecer, pois era rematado absurdo uma negra como aquela "ter critério e tato para saber o que ficava melhor e mais elegante nos trajes confeccionados por elas, para pessoas tão diferentes" (p. 9-10). Depois, encontramos um velho oficial marceneiro, José Carapina, de quem se conta rapidamente a história: fora vendido pelos antigos senhores, moradores de "muito abaixo do rio", onde os donos praticamente se confundiam com os escravos na mesma miséria e quase indigência, tendo vindo para a fazenda do Grotão, onde a nova condição de vida o fazia no início até mesmo sentir vergonha ao se lembrar da situação de carência e penúria dos antigos donos. O Senhor lhe dera depois como mulher a negra Almerinda, que se tornara a mãe de seus filhos. E fora com suas próprias mãos que desbastara os troncos gigantescos para a construção da casa que viria a ser a residência do Comendador e de sua mulher. Para fazer agora o pequeno caixão da menina ${ }^{15}$, ele tivera que chamar para ajudá-lo o negro Tição, "negrinho antipático" que ria nervosamente, o que é dito pelo narrador, mas que na verdade dá a conhecer, em discurso indireto livre, a aversão que o marceneiro tinha pelo ajudante.

De presença mais constante e não somente episódica, Bruno é o pajem do Comendador, sempre ao seu lado nas viagens que ele precisava empreender, sendo também chamado para preparar um carro ou uma caleça quando alguém precisava de transporte. Ciente de sua posição destacada no interior da força de trabalho escrava, a despeito de sua relativa pouca idade, sente-se melindrado quando ordenam que ele faça os animais que atrelava à vitória ficarem em silêncio, numa ordem partida de uma "mulata muito moça", mas releva tudo ao lembrar-se quase de imediato de que o motivo para isso era o velório da menina. Com seu talento para lidar com os animais, basta-lhe sussurrar algumas palavras para que a parelha imediatamente se acalme. Parece também devido a essa mesma posição e ao carinho que sentia pela filha mais nova dos Senhores (era ele que conduzia o carro que levava sempre a passear a menina juntamente com a Senhora), que é incumbido pelas escravas e aceita a incumbência de solicitar a

\footnotetext{
${ }^{15} \mathrm{O}$ fato de o mesmo personagem responsável pela feitura do caixão ter construído a casa dos senhores estende a essa última todas conotações fúnebres ligadas àquele, o que tanto alude às outras mortes que virão - a de Florêncio, assassinado, a do Comendador e a do filho, levados pela doença, e ainda à morte de toda aquela estrutura cujo poder emanava da casa-grande - e à espécie de morte em vida de Dona Mariana, reclusa e depois enlouquecida. Em todos os casos, a morte parece reinar soberana e onipotente.
} 
intervenção de Dona Virgínia para que fosse permitido a elas carregarem "o caixão da Sinhazinha-pequena até o cemitério da cidade", o que acaba terminantemente negado pelo Comendador. Em outro desses momentos de preparo de animais e de carros para transporte de moradores da fazenda, ele não consegue localizar e separar as mulas que deviam ser arriadas, até verificar surpreso que um preto de calças rasgadas e boca desdentada, sem que ele o percebesse, as havia separado para ele, fazendo, ao que parece sem intenção, com que ressaltasse a inépcia do pajem. Diante disso, Bruno atira seu cavalo sobre o negro (que o chamara "Nhô Bruno") e se põe a xingá-lo, conseguindo se acalmar apenas depois de tomar um "grande gole" da garrafa que estava em seu bolso. A causa tanto da dificuldade em juntar os animais como da perda do controle em relação à atitude do outro era o desconsolo por saber que não seria ainda dessa vez que visitaria novamente a Corte, pois não acompanharia a comitiva que partia para buscar Carlota. Era essa a sua "verdadeira loucura" e era mais uma vez que via suas esperanças frustradas. Além disso, não gostava de Dona Virgínia, que nunca o saudava nem mesmo "quando ele lhe dizia com fingida humildade: - Siô Cristo, Nhanhã..." (cap. 23, p. 117). Revelador do que é singular de um determinado personagem, esse episódio não deixa também de ser sintomático da assimetria existente mesmo entre os cativos e da introjeção das relações senhor-escravo pelos próprios negros, que muitas vezes descontam em outro escravo inferior o que não podem voltar contra aqueles que estão acima deles na rígida hierarquia da grande propriedade.

Algum tempo depois do regresso de Dona Virgínia com Carlota, veremos Bruno num estado muito diferente, ao trazer para a sala de jantar as grandes malas do Comendador para serem preparadas para a viagem à corte, pois havia recebido a notícia de que um de seus filhos estava doente, havendo na cidade uma epidemia de febre amarela:

Bruno tudo fazia com largo sorriso na face preta, porque sabia ser ele o acompanhante à Corte de seu senhor, e isso representava para ele maravilhosa aventura. Já se via de armada gravata branca, a vestia azul-ferrete bem esticada no peito, os botões dourados rebrilhantes ao sol, na porta da igreja, à espera do Senhor e vendo entrar as belas raparigas cujos olhares admirativos lhe seriam lançados à socapa, muito sonsas, por trás das donas de vestidos escuros, certas de estarem as mulatinhas muito preocupadas com a sombrinha e as sacas de seda. (cap. 78, p. 341) 
Tempos depois, Bruno retorna sozinho à fazenda, tendo chegado debaixo de pesada chuva. Vinha por ordem do Comendador em busca de dinheiro, mas toda a superioridade que sentia em relação aos demais escravos e a confiança que o senhor nele depositava não impediram a desconfiança do senhor Manuel Procópio: o risco de se entregar o dinheiro a um "moleque que nem é forro". Os trabalhos mais importantes e os eventuais privilégios de que gozavam alguns escravos não suprimiam nunca o fato último e extremamente desabonador do cativeiro. Em franca oposição a essa visão preconceituosa e generalizante dos escravos expressa por intermédio do agregado, o caráter do jovem pajem é construído pelo escritor de maneira rica e complexa, o que se entremostra nos episódios referidos e ainda nos últimos momentos antes de partir de novo para a Corte: nas botas altas que veste e que provocam o olhar severo e a censura do senhor Manuel Procópio, no modo como finge respeito a ele ao abaixar a cabeça, na atitude previdente e cuidadosa com que costura o dinheiro na parte interna do cinturão, no cumprimento efusivo à Sinhazinha, e no respeito que agora parece verdadeiro, e ainda na atitude reticente ao ser indagado por Carlota sobre o estado de saúde do Comendador, até responder candidamente: “- O senhor Comendador também está doente - murmurou depois de abaixar a cabeça o pajem - mas mandou dizer que não é nada..." (cap. 103, p. 450-1) Tudo isso compõe um personagem que é muito mais que apenas um escravo que trabalha como todos os outros e que tem a liberdade como único anseio. Seria mesmo de se perguntar se a libertação dessa condição realmente constituiria um de seus anelos. Não havendo nada no romance que indique que Bruno não tenha voltado para junto do Comendador com o dinheiro que Manuel Procópio mesmo a contragosto lhe entregara, pode-se afirmar que não quis obtê-la pelo menos ao preço da confiança que o Senhor nele depositava. É claro que sua posição era muito superior à maioria dos outros cativos, e sobre alguns deles podia mesmo exercitar autoridade semelhante à do Comendador. Isso, contudo, não torna o personagem menos complexo.

Há uma escrava que também parece despreocupada da liberdade e é figurada de modo ainda mais profundo do que Bruno, sendo talvez, dentre as escravas, a que recebe no romance a melhor caracterização. Trata-se da mulata Libânia, a ama-de-leite da menina: 
O senhor Justino, depois de muitas mesuras, e de dizer palavras entrecortados, foi para o terreiro e mandou dois moleques que fossem chamar os feitores e os capatazes, que eram ao todo vinte, para que se reunissem na sala da casa das máquinas, e para lá se dirigiu. Mas, ao passar pela porta da cozinha, viu, em pé junto ao poial que firmava a entrada, a multa Libânia já pronta para sair, com o vestido novo do Dia do Ano, todo de cassa branca. Era figura curiosa, muito corada, apesar da pele escura, e os olhos fulguravam como se descobrissem a todo o momento a vida e o mundo. Seus braços roliços e suas pernas vigorosas, descobertas pela saia curta e redonda, graciosamente arregaçada na cintura, para a viagem a pé na estrada, eram admiravelmente esculpidas e lisas e ostentavam saúde e força. Trazia pendente do pescoço boa corrente de ouro, com a cruz lavrada, para demonstrar assim bem claro o seu valimento junto aos donos. Tinha sido a ama-deleite da menina, e podia fazer muita coisa que nenhuma outra escrava da fazenda nem sequer sonharia, mas conservava-se, ao mesmo tempo, tímida e audaciosa, infantil e amadurecida, e assim suas atitudes não ultrapassavam de muito as das outras. Abaixou os olhos quando notou que o administrador a fitava, e concertou os refolhos da anágua engomada, com afetação, mas não pôde fingir que o não vira, e balbuciou:

- Sua benção, senhor Justino...

O velho parou, pesadamente, com os pés bem longe um do outro, o grande alcobaça ainda nas mãos, e disse-lhe com autoridade, engrossando talvez propositadamente a voz:

- Nenhum escravo ou escrava, negro algum da fazenda vai acompanhar o enterro, e se eu souber de alguém que desobedeça, receberá dez palmatoadas! Para alguns, ou para algumas, mandarei pôr um grão de milho na palma da mão...

Libânia tornou-se subitamente rubra, e as lágrimas saltaram longe, como se estivessem comprimidas. Esfregou as mãos nos braços com tanta força que produziram certo chiado áspero, e depois apanhou do bolso da saia um papel amarelado, com gestos rápidos e desenvoltos, e mostrou-o ao administrador com irreprimível insolência, exclamando:

- Eu sou livre! Eu sou forra! Aqui está a minha carta de alforria, passada pelo meu Senhor! Não sou negra nem escrava! (p. 38-9)

Em comparação com os escravos do eito, a situação de Libânia é bastante singular. Mulata e forra, nem negra nem escrava, ainda jovem e em pleno viço, esbanjando saúde e força, a ama-de-leite da menina ocupava, assim como Bruno, uma 
posição destacada mesmo em relação a outras mulheres que se encontravam na mesma condição. Símbolos desse prestígio são o vestido de cassa e a corrente de ouro com cruz lavrada. Como seu filho morrera ao nascer, Libânia fora designada para ama da menina, embora também deva ter sido levado em conta nessa escolha o fato de ser mestiça e não negra. Tinha sido até tirada pelos Senhores da companhia do chefe dos terreiros de café com quem eles mesmos a haviam casado, mostrando-se aqui o poder absoluto do proprietário sobre a vida dos escravos. Depois, concederam a ela a alforria, o papel amarelado que Libânia carregava no bolso. Muito provavelmente sua vida não mudara quase nada desde então, sendo o pedido de benção ao administrador apenas uma das permanências e nem mesmo a mais importante, e a única utilidade desse documento devia ser em momentos como aquele em que a queriam obrigar a submeter-se a alguma ordem dada aos escravos e se via ameaçada de castigo, e ela então brandia a carta dizendo-se livre e forra, acrescentando ainda, sintomático da associação entre a cor da pele e a condição de cativa, não ser "negra nem escrava". Vivia num "quarto pequenino, formado de tabiques", e que fora dado a ela apenas "para evitar o seu contacto com as outras negras de dentro, a fim de preservar a menina", e dormia numa simples enxerga. A sua grande preocupação, ao lado do sentimento de dor provocado pela perda da menina, para quem voltara toda a ternura, o afeto e o amor que seriam destinados ao filho, é saber em que atividades irão agora envolvê-la, já que até então tudo o que fazia era sempre de algum modo relacionado à menina. Ao ver que não há ninguém a seguir o cortejo a pé, pois vão pela estrada apenas os carros conduzidos pelas bestas, sente que o fato de ser livre não lhe serve de nada nessa hora, que nada pode fazer. A desistência, contudo, não deve ter deixado de passar pelo medo de vir a ser castigada:

Ouvira cortar o ar uma chicotada violenta, sibilante e sonora como o silvo de animal acossado e furioso, e esse golpe repentino ferira os seus ouvidos com todo o terror acumulado pelas dezenas de anos de sofrimento dos da raça de sua mãe. Era filha de branco e de negra, e nunca soubera quem eram os seus pais, pois todas as vezes que fizera perguntas nesse sentido, quando ainda era criança, recebera em resposta coques e beliscões impacientes. (p. 41)

Dificilmente poderia ser mostrado de modo mais evidente o quão pouco uma carta de alforria, ou algum tipo de "privilégio" no interior do regime servil, ou ainda uma ou outra vestimenta ou adorno especial, ou mesmo uma posição mais prestigiosa podem 
fazer contra os males acumulados em gerações de homens escravizados e mesmo na vida de um determinado indivíduo. Para aqueles que vivenciaram a escravidão, o estalo do chicote com que o condutor procura fazer deslocar os animais não tem como não remeter de imediato às chicotadas que os escravos recebiam cotidianamente. $\mathrm{O}$ fato de ser filha de um homem branco só traz mais um opróbrio e a condenação a não saber quem eram os próprios pais, aprendendo muito cedo, ao custo de pancadas e maustratos, a não fazer qualquer tipo de pergunta nesse sentido ${ }^{16}$.

É talvez por reconhecer o pouco valor daquele papel amarelado que ao fim do capítulo vemos Libânia rasgar em pedacinhos a sua carta de alforria. Só então, segundo o narrador, ela pôde verdadeiramente chorar. Além de termos de considerar aqui também as complicadas relações entre escravo e senhor e a tendência relativamente comum por parte do escravo, com a introjeção de valores e convicções forjados no regime servil, de recusa da liberdade e do anseio pelo estreitamento dos laços que o prendem ao proprietário, pode-se pensar que a ama-de-leite da menina estava assim realizando um ato de sacrifício em sua memória, assegurando que não deixaria a fazenda e a família dela mesmo depois de sua morte precoce. É assim mais um indício do amor verdadeiro, da verdadeira adoração que sentia pela menina branca que amamentara. É quase como uma obsessão que este tema aparece na literatura de Cornélio Penna: a situação ambígua das escravas que se tornavam amas-de-leite e eram, assim, praticamente condenadas a amar seus algozes, aqueles que em realidade deviam aprender a odiar ${ }^{17}$. Eram, além disso, separadas dos outros escravos - como vimos no

\footnotetext{
16 "Raro o senhor de engenho que morreu sem deixar alforriados, no testamento, negros e mulatas de sua fábrica. É verdade que 'o alforriado', observa Alcântara Machado, referindo-se aos escravos das fazendas de São Paulo, nos séculos XVI e XVII, 'é muita vez bastardo, fruto dos amores do testador ou de pessoa da família com uma negra da casa'. Bastardos e filhos naturais - que senhor de engenho não os deixou em grande número?" (Gilberto Freyre, Casa-grande e senzala, p. 609-10)

17 "Esse ajustamento entre senhor e escravo encontra sua explicação na própria estrutura material das grandes propriedades rurais, que condicionou essa complexa síntese de benignidade e extrema violência, compondo, com esses elementos divergentes, o fio das relações entre ambos. Enquanto núcleo doméstico, ela colocou o dependente em relação contínua, e não raro estreita, com os membros da família dominante, tecendo, à maneira clássica, as redes de poder pessoal: o tratamento condescendente dispensado à amade-leite, à mucama, ao pajem, ao companheiro de folguedos infantis representa a objetivação desses aspectos amenos da relação senhor-escravo. O homem reificado e torturado para que a disciplina e a continuidade do trabalho de sol a sol não fosse quebrada concretiza o extremo oposto do continuum de ajustamentos possíveis entre o senhor e o escravo. Essa diversificação prende-se, por certo, às situações particulares em que transcorriam os contactos, isto é, o lar ou o eito. Mas é preciso não esquecer que estas duas situações constituíam uma unidade socioeconômica, a fazenda. Determinadas por esta formação social, as relações entre senhores e escravos permanecem essencialmente as mesmas em qualquer das posições diferenciadas que estes últimos possam ocupar em sua estrutura interna. Significa isto que implícitos no curso dessas relações se encontram a compulsão e a violência em síntese com seus contrários, isto é, a quebra do rigor e a mercê. Basta lembrar que a mucama estava tão sujeita ao suplício, legitimado por seu caráter de coisa, quanto o último dos trabalhadores do eito poderia escapar a ele, desde
} 
caso de Libânia - com quem dificilmente podiam ter algum convívio mais íntimo e assim desenvolver laços mais estreitos, não tendo a quem votar o afeto e a ternura de que eram capazes a não ser para os seus filhos de criação. Consciente ou inconscientemente, porém, não deviam deixar de pensar numa ou noutra ocasião que eram eles os filhos daqueles que os escravizavam. Acompanhavam também o seu crescimento e viam que aquelas crianças eventualmente carinhosas e gentis tornavam-se com freqüência despóticas e cruéis. Mesmo que não cometessem alguma atrocidade contra suas mães-pretas, muitas vezes castigavam ou mandavam castigar cruelmente aqueles que, mesmo não sendo muito próximos, era impossível não reconhecer como iguais. No caso de Libânia, não houve obviamente tempo de acompanhar esse crescimento da menina, mas o apego a ela era tão grande que, com a chegada de Carlota, ela imediatamente e com naturalidade assume o papel de ama da filha mais velha de Mariana e do Comendador, acabando muitas vezes por confundir uma e outra. Assim, na noite mesmo da chegada de Carlota, tendo assumido seu posto junto ao quarto dela, depara Libânia com os olhos arregalados de Carlota e, semi-desperta, pega a caixinha de música que costumava tocar para fazer com que "a menina" readormecesse, confundindo assim as duas irmãs.

Diálogos como o que então se desenrola entre a sinhazinha e a escrava, do quarto até o local onde fora colocado o quadro da menina, pois para lá se dirigiram em função da curiosidade de Carlota despertada pela confusão de Libânia, são talvez mais corriqueiros na casa-grande que aqueles que se dão entre dois homens livres. O convívio de Carlota é indiscutivelmente maior com Libânia do que com qualquer outro membro, mais próximo ou mais distante, da própria família, incluindo-se aí Celestina, quase tão jovem quanto a prima. Desse modo, Carlota, ao não conseguir obter qualquer informação mais precisa sobre os acontecimentos recentes que envolveram sua mãe e sobre o seu paradeiro, acaba por pedir a Libânia que lhe falasse de dona Mariana. E é uma vez mais a complexidade da condição de uma personagem submetida à condição escrava, ainda que formalmente já não o fosse, que pode ser entrevista na narração do esforço de rememoração, das hesitações, do receio de dizer o que não podia ser dito e dos sentimentos contraditórios que brotaram dentro dela diante desse pedido. Desse modo, o que acabou por verbalizar compunha um "amálgama de coisas diferentes, ditas de forma incompleta e as mais das vezes sem coesão", o que também pode ser de Carvalho Franco, Homens livres na ordem escravocrata, p. 211-2.) 
entendido, entre outras coisas, como índice da ausência de elementos encadeadores do discurso naquele ambiente em que os elos entre os fatos eram muitas vezes suprimidos com a supressão de um ou outro acontecimento que se queria oculto, ou ainda ao absurdo e à insanidade do regime servil.

Durante a fala de Libânia, adentra o quarto Joviana, a verdadeira ama-de-leite de Carlota, dizendo - "em tom de avó rabugenta" - que tudo aquilo era "mironga" e acaba por colocar a mulata para fora do quarto. Mas, ao ser pressionada por Carlota, mesmo insistindo que não sabia "dizer as coisas" e que não queria que ela ficasse doente e fosse embora "tal qual a outra", Joviana conta a Carlota alguns fatos relativamente truncados e que se misturam confusamente, num dizer e desdizer típico de quem não quer ou não pode revelar alguma coisa, o que remete às mesmas questões discutidas em relação ao amálgama da fala de Libânia, mas que no caso da escrava bem mais velha indica também a mescla em sua fala das duas culturas:

- A outra, sim, a menina que morreu, e que Deus levou para o céu e está agora pedindo negro lá em cima, lá onde os brancos dizem estar o Paraíso. Pois é mesmo, a outra, a que ficou doente, por castigo de Deus... Nossa Senhora! Não foi não, Nhanhã! Ninguém foi punido, nem mesmo o Florêncio foi castigado... (p. 441)

Antes mesmo do final dessa conversa, devido talvez à voz de acalanto da negra, Carlota termina por adormecer, e aquela não consegue deixar de exclamar para si mesma, depois de uma interjeição: "A negra velha está para ficar doida! Agora me parece ter falado com a Sinhá Dona Mariana!” Tendo Libânia assumido o lugar de ama de Carlota assim que ela retornou ao Grotão, esta acabara se esquecendo de Joviana, até que um dia, ao conversar com Celestina na entrada do pátio, quando chegavam algumas negras com cestos carregados de bananas, passara a relembrar o tempo em que era menina e vinha ver os escravos trazerem os cestos cheios de café, quando fazia exatamente como a menina, furtava chapinhas e as dava às negras. Recorda então que a principal agraciada era Joviana, que estava "ajuntando para se forrar". A recordação faz com que se lembre de que não havia visto ainda a sua mãe-preta e imediatamente vai com Celestina procurá-la. Bem mais velha que Libânia, Joviana tinha sido alforriada como a mulata. Ao ser manhosamente questionada por Carlota, que sugeria que a ama não procurara a sua Nhanhã desde que ela chegara porque estava agora forra, ela responde: “ - Eu estou forra, eu estou forra... eu estou forra... a negra velha nunca será 
forra... nunca será forra... será sempre escrava de sua Sinhazinha. Sinhazinha pode mandar matar sua preta..." (p. 288). Embora tivesse se sentido magoada pelo esquecimento da Sinhazinha, esquece tudo ao ver Carlota determinar que volte a ser sua ama, dizendo que faria de Libânia sua criada de quarto. E responde, despeitada: “ Criada de quarto, aquilo?!" Esse lado rabugento e predisposto contra o outro, de quem não tem medo do que vão pensar dela e nem papas na língua, é uma das características que fazem de Joviana uma personagem que traz algum humor para o romance. Mesmo naquela afirmação terrível sobre o direito que Carlota tinha de matá-la não deixa de haver algo de exagerado e burlesco. Um dia, depois de vê-la em conversa com Dona Maria Violante, a mulher da Corte que chegara com Dona Virgínia e Carlota, Joviana fita esta última com ar de reprovação:

- Que é... Joviana?

- Ah, Nhanhãzinha, eu estava com vontade de ir buscá-la lá fora. Que tanta conversa com a senhora Dona Maria Violante! Onde já se viu senhora que teve dois maridos! Conhece tanto homem! Ela não serve para conversar com a minha Sinhá-moça!

Carlota riu-se, e sentiu grande conforto a lhe aquecer o coração. Tinha se esquecido de Joviana... (p. 357)

Mais uma vez, é possível perceber que o calor humano com que Carlota podia contar na fazenda do Grotão provinha sempre dos escravos, a despeito de todo o sofrimento, de toda a opressão.

Outros escravos poderiam ser ainda mencionados, como Joana Tintureira, Mãe Cambinda ou Maria Crioula, embora não tenham no romance o relevo desses três que foram abordados com mais vagar, mas aquela de que não se pode deixar de tratar de maneira um pouco mais detida é Dadade. Fora ela a ama do Comendador e agora, paralítica, vivia presa ao catre na senzala. Era um aposento miserável e sem janelas, mas onde o feitor mandara colocar uma cadeira austríaca ao ver algumas vezes o Comendador de pé ao lado da antiga ama. A velha Dadade era africana e conhecera os avós da família Albernaz, tendo muitas histórias para contar sobre a antiga fazenda "da Oliveira" e sobre a antiga Sinhá. Celestina gostava de ir até lá ouvi-la e parecia ser por ela confundida com Nhanhã Clara, a avó do Comendador. As histórias que ela lhe contava descreviam a fazenda sempre como um verdadeiro paraíso de riqueza, 
fecundidade e paz, em que todos viviam em harmonia e justiça. Ocorre que um dia Dadade resolve contar uma outra história. Teria acontecido com a Sinhá velha e é uma narrativa assustadora sobre uma mucama que surge ao seu lado um dia, desconhecida dela, mas que executa todas as tarefas ligadas aos seus longos preparativos para o repouso noturno de modo exemplar e muito mais adequado do que as outras mucamas de quarto. Mas, sempre de cabeça baixa e cabelos caídos, ela não deixava a sinhá verlhe o rosto, e respondia sempre numa linguagem ininteligível às perguntas sobre quem era e quem a mandara servi-la. Dadade descreve minuciosamente as etapas da toalete da sinhá de modo a intensificar o suspense sobre a identidade da negra. E, finalmente, revela que a sinhá, munindo-se de um castiçal, conseguira agarrá-la e aproximar a luz do rosto, que ela a todo custo procurava ocultar. Sem, porém, informar de quem se tratava, Dadade apenas deixou o silêncio reticente aumentar a curiosidade de Celestina, que não teve como não indagar e pedir mais de uma vez que ela lho revelasse:

- Conte, vovó Dadade...

- A Sinhá Velha no princípio não conseguiu perceber nada mas sentia que a negra escapava de perto da cama, e então segurou-lhe os cabelos, que eram finos e lanzudos, e levantou-os. E deu um grande grito, que todos da fazenda ouviram...

- Por que, vovó Dadade?

- Porque ela não tinha rosto não... Nhanhã Clara! Celestina a princípio não entendeu bem. Depois, quando compreendeu tentou levantar-se e fugir, mas não pôde, pois as pernas se recusaram a mover-se. Ao fim de algum tempo quis reagir e firmou a voz para perguntar:

- Não tinha rosto, como?

- Não tinha não, Nhanhã Clara. A vela alumiou um vazio. Era só cabelo e pescoço... (p. 136)

Celestina é então tomada pelo medo, reconhecendo agora, num átimo, ao lembrar-se da crueldade dos antigos senhores e das lendas horríveis que corriam sobre eles, não como essa história era absurda e inverossímil, mas ao contrário como deviam ser falsas aquelas outras histórias que falavam em prosperidade, beleza e bondade, pois que era impossível combiná-las com essa história da negra sem rosto. Todos os seus sonhos pareciam condenados a se revelarem falsos e mais um parece ter o mesmo destino, o de que Dadade a confundia com Nhanhã Clara, pois, ao vê-la ir-se embora, Dadade pede que ela não o faça, chamando-a Nhanhã Celestina. Diante de seu espanto, 
porém, a negra velha disfarça, para ao final, quando ela efetivamente está se retirando, chamá-la novamente Nhanhã Clara.

O que poderia parecer fruto de esclerose advinda da idade já bastante avançada revela-se em outro episódio como uma estratégia consciente de engano dos senhores e dos demais homens brancos. É quando Carlota visita Dadade a pedido de Celestina, que estava doente, com o fito de mantê-la no suposto engano de que é Nhanhã Clara que a está visitando. E de fato, Dadade a recebe como se fosse a antiga Sinhá Dona, dizendo que sente "falta de [seus] brancos", falando mal dos negros dali e de como eram diferentes dos negros da fazenda, "todos bons, todos legítimos de nação", e contando histórias desse tempo. Carlota, entretanto, incapaz de fugir, mesmo que por uma boa causa, à sua natural honestidade e franqueza, sente-se mal ao representar aquele papel e acaba por confessar a Dadade quem era de fato. E a velha negra lhe responde:

- Ora, Nhanhã Carlota, eu sei que Sinhá Celestina está doente, até acho mais perrengue do que eu... Mas a minha Sinhazinha pode dizer que a negra tem pedido a todos os santos pela saúde dela... (p. 377)

Em lugar de uma pobre velha caduca, Dadade mostra-se assim dona de grande lucidez, pronta a representar o papel que os brancos gostariam que ela representasse, pronta a dizer o que eles querem ouvir, mas pronta igualmente a sugerir-lhes, ainda que por meio de uma lenda aterradora, a consciência sobre o horror do sistema em que os brancos assentam seu poder e fortuna e onde os negros são o suporte e as vítimas preferidas, sem deixar de lembrar-lhes que eles podem muito bem tornar-se os instrumentos da vingança.

Quando Celestina, convalescendo, a visita novamente, apresenta-se como Celestina, e Vovó Dadade ri baixinho, segundo o narrador, "decerto por se lembrar do logro de tanto tempo, enquanto fingia confundi-la com a antiga e poderosa Sinhá" (p. 457-8) E, depois de um rápido diálogo, pede a Celestina que fizesse a caridade de fazer com que os escravos tirassem um bode preto que sempre colocavam num poste que ficava na varanda em frente ao seu quarto. Celestina procura verificar e não consegue ver nenhum animal. Pergunta então a algumas escravas e elas lhe informam que nunca entravam animais ali. De volta a Dadade, Celestina lhe repassa essa informação, e ela, depois de algum tempo virada de costas, deitada no catre, murmura que não era cabra, e que sabia que era "outra coisa". Esse mistério se tornará ainda mais perturbador quando, 
quase ao final do romance, Carlota reparar num bode preto amarrado numa das colunas da varanda, muito perto da sala de suplícios de onde acabara de sair. E diante disso talvez seja preciso relativizar o que foi dito até aqui sobre Dadade, pois talvez tenha sido uma tentativa de compreensão da personalidade da negra velha de um modo muito racional e cartesiano, especialmente porque se trata de uma personagem que vem de uma cultura que não é nem racional no sentido que o empregamos, nem muito menos cartesiana. Dadade é assim muito mais do que alguém que finge conscientemente isto ou aquilo, de acordo com esta ou aquela estratégia. Sem deixar de ser assim, é também alguém que intui o desmoronamento daquela estrutura que conhecia tão bem, a dissolução da família e a ruína da propriedade, tudo o que iria coincidir com a própria morte. Mostra-se assim portadora de uma sabedoria profunda, fundada nas histórias, causos e lendas que devia ter ouvido e que também contava, no conjunto tão grande e diversificado de experiências que tivera, na infância ainda na África longínqua, e depois no cativeiro, em que deve ter visto e vivenciado os piores horrores, nos conhecimentos que adquirira por conta própria ou que foram a ela transmitidos pela cultura oral ${ }^{18}$. Mas nem isso explica inteiramente a menção ao bode preto. Como saber? Nem tudo se explica, muito ainda restará inexplicado no romance como na vida.

A morte da escrava quase centenária, com um enterramento tão precário quanto a vida que levara, apenas tornado menos deplorável por Carlota ali orar de joelhos, acompanhada por Libânia e Manuel Procópio, e por depositar sobre a cova simples o pequeno crucifixo de ouro que usava, parece em alguma medida simbolizar o fim de uma era, com tudo que ela possa representar. Pouco antes disso, Manuel Procópio havia dito a Carlota ter ido fazer a declaração de óbito da escrava e então ficáramos sabendo por ele que Dadade era o apelido de Felicidade. Amarga ironia ao atribuir esse nome àquela que tanto deve ter sofrido em toda sua longa vida, essa atribuição pode também aludir às pequenas alegrias que ela encontrava, a despeito de sua condição, nas conversas que entretinha com outros negros ou com os homens brancos, nas peças que pregava nesses últimos e nas histórias que lhes contava.

Assim, se é verdade que por vezes os escravos acabam por reproduzir e mimetizar as relações senhor/escravo naquelas que se dão entre os próprios cativos, como no caso de Bruno com o escravo maltrapilho, e José Carapina, com o negrinho

18 "Duas informações básicas são fornecidas pelo estudo de Dadade: a) ela é a detentora de um poder que se põe fora do conflito entre os pólos masculino e feminino, ambos incluídos no lado senhorial, e introduz o escravo, socialmente dominado, numa posição invertida: dominado, é, entretanto, possuidor de um saber que o branco dominador ignora." (Luiz Costa Lima, O romance em Cornélio Penna, p. 172) 
Tição, especialmente em função da hierarquia existente no interior de sua "classe", a figuração deles como individualidades específicas e irredutíveis e a dramatização de suas vidas singulares, por mais que essas nunca possam de todo ser destacadas da condição servil, nos mostram a complexidade do romance ao tempo em que aludem à complexidade da própria vida, ainda que rebaixada a uma condição quase inumana. A escassez de traços singulares relacionados aos escravos do eito, ao contrário, pode ser vista como índice das barreiras quase intransponíveis para a expressão individual daqueles inteiramente submetidos aos trabalhos forçados no campo e dos limites da expressão artística dessa condição, como a voz que, não querendo calar de todo diante da iniqüidade inenarrável e da inumanidade absoluta, não pode aludir a esses seres espoliados senão como massa indistinta, de onde eventualmente emerge, contudo, um grito solitário e lancinante de dor:

Era já a época da colheita, e ao longe surgiam os bandos de homens e mulheres de roupa branca com listas de cores muito vivas, todos de cabeça coberta, ocupados em derriçar os galhos e enchiam grandes cestos pousados junto de cada um. Trabalhavam em silêncio, mas de vez em quando erguia-se uma voz em grito prolongado entre gemido e uivo, sem palavras, a cortar o ar tal afiada faca, tão espessa e pesada estava a atmosfera, carregada de perfumes dos arbustos maltratados por aquelas mãos que se levantavam e abaixavam em movimentos ritmados. (p. 155-6)

Paradoxalmente, naquele universo dantesco, a única expressão possível é aquela que, comum a todos, menos poderia distingui-los.

\section{Entre o escravo e o senhor: exemplaridade e singularidade}

Talvez ainda mais bem delineados que os escravos, os agregados - quem sabe não seria mais adequado dizer as agregadas, pois são quase todas mulheres - têm um papel muito destacado no romance. Dona Inacinha e Sinhá Rola, Dona Virgínia e Celestina, sem contar Dona Maria Violante, uma espécie de candidata a agregada, e mesmo a Senhora Luísa, que não é propriamente uma agregada, mas uma empregada da família, bem como Manuel Procópio, a exceção masculina mais importante, são personagens traçados com mão de mestre. Curiosamente, deles talvez se possa dizer que são personagens secundários alçados ao primeiro plano. $\mathrm{O}$ agregado é uma figura muito conhecida em nossa literatura e é quase impossível pensarmos nele sem lembrarmos do 
nosso maior escritor e seu agregado mais emblemático, José Dias, em Dom Casmurro. Haverá certamente algumas coincidências dos agregados cornelianos com o personagem machadiano e neles será possível encontrar mesmo alguma dose de humor, é verdade que muito menor do que em Machado de Assis. Sinhá Rola sobretudo é uma personagem algo risível, mas a história dela e da irmã nada tem de bem-humorada, tendo, isto sim, um caráter de exemplaridade dessa triste condição, o que faz com que, com um ou outro ajuste, possa ser estendida para inúmeros outros agregados, na literatura e na vida real.

Com a morte da mãe, o pai havia, com sofreguidão, feito "dinheiro de tudo" e partira para a Corte, deixando-as desamparadas na fazenda em que sempre viveram. Lá, entregou-se à paixão pelo jogo e começou a desbaratar tudo o que a família possuía. Sem qualquer experiência de vida, elas tornaram-se reféns do administrador e viram seus bens serem gradualmente dilapidados pelas ordens que o pai enviava para que fossem vendidos e o dinheiro a ele remetido. A notícia de sua morte chega praticamente ao mesmo tempo em que são informadas de que a propriedade devia ser desocupada, pois não mais lhes pertencia. Não sabendo mais o que fazer, recebem um dia a visita do primo Comendador, que vinha buscá-las para que morassem com ele em sua fazenda. A delicadeza da fala do primo em que invertia os papéis entre quem prestava e quem recebia o favor não impediu de sentirem muitos anos depois a permanência em sua casa como um "cativeiro recebido com resignada amargura, renovado todos os dias por pequeninas coisas que feriam com suas minúsculas arestas aqueles corações cobertos de chagas incuráveis" (p.84). Velhas e solteironas, residindo numa casa que não era a delas, sem ter para onde ir caso um dia tivessem que deixar a propriedade alheia, viviam o tempo todo com esse receio e esse temor. Para além dessa preocupação com o futuro, só havia as lembranças do passado, quase sempre amargas, quando não propriamente por seu conteúdo, por seus planos não terem se desenrolado conforme chegaram a sonhar. É nesse sentido que a figura de Sinhá Rola chega a ser algo patética. É chamada de velha-moça pelo narrador, e é descrita exatamente por meio dessa mistura. A própria brancura do colo, que dera origem ao apelido, era mantida como na juventude, mas agora recobria uma pele fanada pelo tempo; as vestes e o penteado que usava semelhavam os de menina e estabeleciam assim um contraste com o corpo que era então o de uma mulher envelhecida. Essa idade avançada também contrastava com a ingenuidade e os dengos e atitudes de criança. E não poderia faltar a rememoração insistente de um amor que conhecera na adolescência e que por muito pouco não virara 
casamento. Vimos já como Celestina, ao entrar na sala de visitas, depara com ela sentada ao clavicórdio a cantarolar baixinho uma canção sentimental, antes de ser tomada pelo choro. Vexada, confessa à moça que chorava porque se lembrara de um moço que gostara dela, e então passa a contar "a sua história sofregamente, como jovem colegial contaria à sua colega e companheira de banco, o seu primeiro namoro”. (p. 107) A sua grande mágoa era ter sido ela a recusar a proposta de casamento que ele lhe fizera, aconselhada sobretudo pela irmã, Dona Inácia, que lhe mostrara os riscos de se casar com um homem sem fortuna e posição. E a grande dúvida de Sinhá Rola desde então era se a irmã não a teria dissuadido do casamento movida pela inveja.

O que Cornélio Penna dramatiza aqui não é apenas a situação do agregado, é o que é próprio da condição humana, a dúvida sobre ter ou não tomado a decisão mais acertada ou a desconfiança de não tê-lo feito, o arrependimento do que não tem mais volta, a imaginação e mesmo a idealização de como teria sido a sua vida se outra tivesse sido a escolha feita, a suposta felicidade que teria experimentado face aos desgostos e tristezas que na realidade enfrentou e enfrenta, e ainda a incerteza sobre o móvel da ação do outro, que tivera naquele momento um papel tão preponderante, o que poderá nunca ser esclarecido. De todo modo, as dúvidas, decepções e frustrações tornam-se ainda mais agudas na situação de dependência em que Sinhá Rola se encontra. A realização do casamento, nesse sentido, poderia ter sido não apenas a obtenção da felicidade almejada, como também o meio por que escaparia da condição de agregada na fazenda do primo, evitando assim todas as pequenas humilhações cotidianas, a sensação de ser um estorvo, a insegurança quanto ao futuro, não apenas o futuro distante, mas o dia seguinte mesmo, quando por qualquer motivo poderiam ter de deixar casa do primo.

Sendo a irmã mais velha, e tendo sido ao que parece imune a essas "veleidades" de casamento, Dona Inácia, embora vivesse provavelmente as mesmas angústias quanto ao amanhã, ao invés de se voltar para o passado ou para um futuro incerto, procurava de algum modo intervir para que ele não viesse a se mostrar tão funesto. Num dia em que a irmã lhe conta ter sonhado que todos na casa morriam e que ficavam elas sozinhas e desamparadas, expressando seus receios quanto ao porvir, Dona Inacinha lhe mostra a carta que recebera do Visconde, o irmão do Comendador, que - em resposta a uma carta que ela, D.Inácia, lhe enviara por intermédio de Dona Virgínia - se dizia disposto a acolhê-las em sua fazenda quando elas assim o desejassem, ou então colocaria à 
disposição das irmãs "duas negras de ganho"19 para o sustento delas caso preferissem viver na Corte. Esse exemplo é suficiente para mostrar a personalidade pragmática de Dona Inácia por oposição ao caráter sonhador e mesmo infantil da irmã, mas, se omitirmos a continuidade de sua fala, pode levar ao engano de vê-la como uma personagem exclusivamente voltada para os seus problemas e interesses:

- Assim estou tranqüila quanto aos nossos últimos dias... Mas por isso mesmo sinto funda inquietação, verdadeiro remorso, ao ver tudo em torno de nós tornar-se cada vez mais confuso... Desde a morte da menina parece que nesta casa alguma coisa quebrou, e toda ela está ameaçando desabamento...

Depois ergueu-se, sacudiu o vestido cheio de fios, e pareceu corajosa e forte. Com rápido sorriso exclamou:

- Pareço coruja agourenta! Mana, não pense mais em nada disso porque nós não somos ratos que abandonam os navios que vão afundar... (p. 353)

Assim, se Dona Inacinha possui de fato uma índole muito mais voltada para as coisas práticas, especialmente quando comparada com a irmã sonhadora, a ponto de dissuadi-la de entregar um retrato de Dona Mariana a Carlota, ela mantém dignidade suficiente para, mesmo tendo agora um outro lugar para onde se voltar, não desejar a ruína da família que, bem ou mal, a abrigara e à irmã por tantos anos. É essa mesma integridade de caráter que faz com que, ao assumir o governo da casa quando da ausência de Dona Mariana e estando Dona Virgínia, a parenta mais próxima do Comendador, também ausente, ela não exorbite de suas funções, sobretudo em relação aos escravos, a quem continua tratando sempre de modo afável e cortês, o que não significa que não possa entrar aí alguma condescendência superior, nem que todos se sintam felizes com seu modo de administrar. Sobretudo Dona Frau, notando que ela acabou por assumir indevidamente, segundo crê, algumas de suas funções e sentindo pesar sobre si o seu autoritarismo, não vê a hora de Carlota chegar, e não faz segredo disso. Essa mesma postura algo autoritária é sentida pela irmã mais nova, e boa parte de seu temperamento infantil deve encontrar explicação no convívio tutelar praticamente ininterrupto com a irmã mais velha desde a infância. Se Sinhá Rola estivesse errada ao pensar que fora a inveja que levara a irmã a sugerir que desistisse do casamento, é provável ao menos ter pesado nisso o desejo de D. Inácia de controlá-la e manter a

\footnotetext{
${ }^{19}$ Essa proposta mostra o quanto estava consciente o escritor de que, se o destino dos agregados não era absolutamente promissor, o dos escravos era muito pior.
} 
ascendência sobre ela. ${ }^{20}$ Essa característica certamente a levaria a chocar-se mais frontalmente com Dona Virgínia, quando de seu retorno à fazenda, mesmo que o direito não-escrito estivesse ao lado desta, não fosse Carlota assumir sem grande demora e de maneira inquestionável o lugar deixado pela mãe.

Com a notícia da doença do Comendador e os sinais cada vez mais fortes de que acontecimentos ruinosos se precipitavam, Dona Inácia e Sinhá Rola, a despeito da própria imagem dos ratos que abandonam o navio, sentem-se ainda mais contentes e aliviadas ao receberem uma outra missiva, agora de uns parentes, também fazendeiros, que tinham se mudado para o "sertão de São Paulo", "onde [diziam] os cafezais plantados já davam indícios de grande riqueza" (p. 424), sugerindo que seriam bemvindas se resolvessem mudar-se para aquela região isolada e selvagem. E ao final acabarão mesmo por abandonar o Grotão sem coragem sequer para se despedirem de Carlota. Todavia, mais revelador do que essas cartas, a indicarem que, para onde quer que fossem, a sua situação de agregadas não iria em absoluto se alterar, é o momento verdadeiramente tocante e confrangedor em que escolhem os presentes que darão a Celestina em seu casamento. Sinhá Rola já se decidira a dar a ela duas jarras que tinham sido destinadas a seu próprio matrimônio e as lavara com o último sabonete de alfazema que estava guardado no fundo da gaveta, "ainda na mesma caixa em que viera da França":

Fora trazido há muitos anos da Corte, por uma parenta velha quando em visita à sua mãe, e lhes deixara inesquecível impressão de riqueza, pois ao abrir as canastras, chegadas pela tropa, ela as desfizera diante dos olhos deslumbrados das duas meninas. E de lá do fundo daquelas malas, as quais ao serem abertas tinham exalado o perfume mágico das coisas caras, a senhora desembaraçara duas caixas de sabonete e de água-de-colônia, que Inacinha e Sinhá Rola, muito meninas ainda, haviam recebido sem nada dizerem. A senhora ficara ligeiramente interdita, julgando tê-las desapontado pois decerto teriam preferido bonecas de cera, e hesitara muito ao lembrar da idade delas, já avançada para brinquedo. Todavia nunca poderia imaginar o que foi realmente aquele presente para as duas, que o tinham levado para o quarto muito caladas, devagar, encostando-se às paredes, mas depois de fechada a porta, ao se verem livres dos olhos da estranha, abriram

\footnotetext{
${ }^{20}$ Simone Rossinetti Rufinoni afirma, talvez com razão, que "Dona Inácia incorpora os atributos caros à autoridade senhorial... [...] É doce e severa, em um momento pede auxílio, em outro mostra-se cruel." (Favor e melancolia, p. 69.)
} 
sofregamente os embrulhos. Aspiraram com prolongada delícia o seu olor, depois experimentaram no rosto a doçura do papel sedoso que os envolvia, pintado com flores e folhas de lavanda de tom esmaecido, de ouro velho, muito esguias, em forma de coroas. E, por longos anos, quando elas queriam convencer-se de serem já moças, e chegara para elas o tempo de serem belas e admiradas, iam ao quarto e às ocultas abriam as caixas, ainda cobertas pelo mesmo papel e amarradas pelas mesmas fitas, e ficavam ali esquecidas, embriagadas pelo aroma muito leve, delas exalado em invisíveis volutas, incenso de sua vaidade adolescente. (p. 497)

Não é difícil imaginar, depois da leitura desse fragmento que tem um tom inegavelmente lírico, o que representava para Sinhá Rola a decisão de usar aquele último sabonete para lavar as jarras que seriam dadas a Celestina. Dona Inacinha entretém-se a ver a irmã aprontar o seu presente, e depois começa a preparar o seu. Quando Sinhá Rola vê que ela separara a guarnição de casamento da mãe delas, mostrase espantada e hesitante ao ouvir que a irmã iria dá-la a Celestina:

As duas entreolharam enternecidas e verificaram simultaneamente o ponto a que tinham chegado, as marcas do tempo em sinais indeléveis em seu rosto, e até mesmo a curva de seus corpos para a terra, na força de seu chamado... Sem combinar, sentaram-se na borda do catre e ficaram quietas, mas balançavam o corpo, no mesmo ritmo lento, e pareciam ninar a sua velhice.

- Minha querida - disse por fim Dona Inacinha - nós vamos sair desta casa, e se sabemos para onde vamos, não sabemos o que nos espera... Novas tristezas, novas asperezas, e novos espinhos... Já sei - interrompeu ela, ao ver o gesto de protesto cansado e humilde da irmã. - Já sei: estamos acostumadas... a tudo, e há muito tempo que nos esquecemos de nós mesmas. De tal forma, minha irmãzinha, que até creio já não vivermos mais. Ficamos esquecidas aqui no mundo, sem ninguém precisar de nós, e a única coisa ao nosso alcance em benefício dos outros, é nos fazermos pequeninas para ninguém sentir a nossa presença...

O quarto escurecia pouco a pouco, e a voz da senhora parecia vir da sombra, em vibração muito fraca, exausta. Sinhá Rola a escutava imóvel, e parecia viver o que ela dizia, e cobrir-se com aqueles véus de cinza, para proteger-se em seu sonho de sossego mortal.

- Nós formamos ainda o pequeno laço, o nó a prender ainda, dando-lhes realidade, às nossas recordações de família. Mas talvez dentro de pouco tempo ele se romperá, e tudo será dispersado pelo mundo, sem significação, sem o amor e o 
respeito que lhes dá vida, alma e finalidade. (...) Eles serão agora a carícia, o conforto a darmos a essa menina, mais feliz do que nós, e assim deixarão de ser coisas mortas... (p. 499-500)

É dessa forma que o escritor dramatiza o desconsolo da velhice, a melancólica sensação da passagem do tempo, sentimentos aqui estreitamente vinculados à condição de dependência e de relativa pobreza, em que um sabonete importado parece ter o valor de uma jóia rara e em que o tesouro mais precioso herdado da mãe eram os lençóis de linho bordados que compunham seu enxoval, ambos tornados um $d^{2} m^{21}$ que se dá àquele que nem era considerado assim tão próximo, mas apenas alguém com quem se convivia e que se sabia encontrava-se na mesma situação, mas que se crê fará uso efetivo dos presentes, que ganharão vida com esse uso, a vida que até então nunca tiveram. É por isso que Dona Inacinha recusa terminantemente a sugestão da irmã de darem o jogo de cama a Carlota ao invés de com ele presentearem Celestina. Fazê-lo, argumenta a irmã mais velha, seria condená-los a continuar sendo coisas mortas, pois ela sabia que Carlota, mesmo se viesse realmente a se casar, nunca iria usá-los de fato. A mesma figuração, além de sugerir o modo como a gratuidade do dom pode brotar mesmo de uma situação relativamente precária, não deixa de aludir à poesia que pode ser encontrada nesse envelhecimento ainda que em vidas marcadas por carências e privações, por meio de uma expressão de profundo lirismo como "pareciam ninar a sua velhice" e da narração do cuidado afetuoso de uma para com a outra irmã.

Também agregada, mas de um outro tipo, é Dona Virgínia. Parente mais próxima do Comendador, nutre - a despeito do friável de sua posição - um profundo desprezo por Dona Mariana e sua família. Nada é muito claro, mas resta sugerido em diversas ocasiões que essa família não estava para ela à altura da família Albernaz em termos de nobreza e riqueza, tendo suas atividades vinculadas antes à política, que ela parece desprezar, que à grande propriedade agrícola. O verdadeiro ódio que sentia em relação à mulher do Comendador, contudo, devia ter como motivação em grande medida o modo como fora recebida por Dona Mariana, que nunca deixara de se mostrar altiva, fria, mal a encarando de frente e pouco the dirigindo a palavra e, quando o fazia, era "como se cada uma delas fosse esmola que deixasse cair quando se encontravam" (p. 89). O motivo de se ter refugiado junto ao primo era semelhante ao das irmãs

\footnotetext{
${ }^{21} \mathrm{O}$ caso do sabonete é ainda mais significativo, pois ele é utilizado apenas para lavar e perfumar os dois vasos, sendo por assim dizer consumido no ato em que é doado, sendo de algum modo análogo ao potlatch, como descrito por Marcel Mauss.
} 
solteironas, mas quem dissipara quase tudo o que possuía fora o marido, que tinha se entregado à bebida e que constantemente "fugia de sua casa para a senzala, onde permanecia dias seguidos". Premida pelas dívidas que ele contraíra, ela tivera que entregar quase tudo o que possuía, ficando apenas com as terras - gostava mesmo de frisar que era ainda proprietária -, e com sua morte não teve alternativa a não ser procurar o Comendador. Embora este a recebesse "com simplicidade", ela nunca deixava de alfinetá-lo com notícias que de algum modo revelassem a superioridade do irmão com quem ele não se dava. O que tinha como alvo a mulher devia ser também o seu modo de se vingar do favor que ele lhe prestava, o que ela, tão orgulhosa, não podia perdoar. Nem os escravos escapavam de suas ofensas e grosserias, o que devia ser fruto de seu temperamento mesmo, mas que também não deixava de ser a vingança de uma senhora orgulhosa rebaixada à condição de agregada. Com relação aos outros agregados, a sua postura é em geral de declarada superioridade e manifesto desprezo, sobretudo diante de Celestina, mas que é apenas um pouco menos explícita no caso de Dona Inacinha e Sinhá Rola, pois eram parentes mais afastadas do primo e ainda mais empobrecidas do que ela. Depois do retorno da Corte, procura sempre mostrar a Dona Inacinha ser ela, D.Virgínia, a responsável pelo governo da casa de acordo com a hierarquia estabelecida pela tradição.

A despeito disso, manifesta pesar pela morte da menina e parece sentir-se tão triste como os demais pela sua perda. Boa parte desse sentimento deve ser creditado ao fato de ter tomado a seu cargo a educação da menina e os cuidados que a ela deviam ser dispensados à medida que a Senhora tornava-se mais e mais alheia e reclusa. A morte da criança implica a cessação desses encargos que lhe permitiam de algum modo recobrir a situação de dependente com a muito mais enobrecida função de preceptora ou algo parecido. Com a partida de Dona Mariana, ela tenta substituí-los pelo governo da casa, mas aos poucos Carlota o vai tomando para si. Não é, porém, sem luta que Dona Virgínia vai cedendo terreno a ela, e sem muitas vezes prorromper em lágrimas diante do que vê (e não deixa de declarar) como falta de respeito para com os mais velhos. E a gota d'água é a notícia de que, com a morte do Comendador, Dona Mariana irá retornar ao Grotão. Diante disso, Dona Virgínia organiza uma caravana e parte "em demanda da fazenda do senhor Visconde", levando consigo aquela que tinha sido até então uma espécie de aliada, Dona Maria Violante, e sem dizer a Carlota "uma só palavra” (p. $529)$. 
A impressão de que no caso de Dona Virgínia, mais do que no de qualquer outro morador, o sentimento em relação à menina tinha muito de superficial e era em larga medida movido por interesse próprio é a cessação de todos os seus pesares e a excitação indisfarçável que toma conta dela às vésperas de sua partida para a Corte, por ordem do Comendador, para que buscasse Carlota. Primeiro, não cabe em si por ter sido a escolhida e por tal escolha deixar evidente a sua importância perante os demais; depois, a todo momento impaciente por que as outras mulheres da casa lhe fizessem perguntas, observações e pedidos que de algum modo deixassem em evidência a notícia de sua partida; e, finalmente, ao fazer com que Celestina externasse a opinião sobre qual vestido ela deveria usar na Corte quando se apresentasse no Paço, a falta de sensibilidade para perceber que as reticências da moça, como esta afinal a contragosto o confessa, davam-se em função de não ser de cor preta nenhum dos vestidos que a senhora lhe mostrava, sendo que ela esperava que Dona Virgínia, mesmo na Corte, mantivesse o luto pela menina.

Não é só nesse episódio que Celestina demonstra a sua nobreza de caráter, no geral sempre superior ao das outras agregadas. E parece sintomático o fato de ser a mais pobre de todas. É a única, na verdade, que sempre fora pobre e não empobrecida ou de família decadente. Ademais, era apenas uma parente distante de dona Mariana, sua prima em segundo grau. Essa dupla situação era sempre motivo para ser desprezada pelos demais. Apresenta uma simplicidade e uma singeleza que parecem aos outros obtusidade ou hipocrisia. Acostumados a fingir, a ocultar e a mentir, parece-lhes inconcebível que ela de fato não saiba quase nada - e menos até que eles próprios - a respeito da prima Mariana e dos últimos acontecimentos que transtornaram o Grotão, e ficam mesmo indignados diante das suas perguntas, que lhes parecem ou tolas ou falsas.

Se não chega de fato a ser limitada, Celestina é certamente ingênua a ponto de ser enganada por Dadade, e tão simples que não consegue saber como se comportar diante do Comendador ou mesmo diante da prima, a mesma dificuldade que acaba por manifestar até quando está junto de Carlota. Parece ser contudo esse caráter ingênuo e simples o que a "salva", pois que ela é a única dentre todos os moradores que irá iniciar uma vida verdadeiramente nova, desvinculada dos proprietários e de qualquer relação de compadrio e de favor. O acaso teve nisso um papel determinante. Ela ficara doente e o velho médico fora chamado, mas ele também estava adoentado e mandara em seu lugar um médico bem mais jovem, o doutor Pedro Frota. A doença a princípio não parece grave, mas vai se mostrando aos poucos de relativa gravidade, pois o pulmão 
direito estava comprometido, o que passou a exigir uma presença mais constante do médico. Quase de imediato, Carlota e as outras mulheres percebem que entre a paciente e seu médico dá-se algo que não tem relação direta com a doença. Os comentários algo maldosos das mulheres, como o de que a doença de Celestina é imaginária e de que ela ficava muito bem disposta no dia da visita do doutor, vão deixando mais claro o que se passava entre os dois, até que, praticamente recuperada, Celestina confessa a Carlota que eles pretendem se casar. O consentimento que Celestina pretendia obter do Comendador, atitude que demonstra nitidamente não terem as relações de dependência nada de vago e intangível, é dado pelo senhor Manuel Procópio, que era na realidade o tutor da moça, embora ele mesmo dissesse que, embora tivesse tratado "dos papéis e dos proclamas", aguardava apenas a palavra de Carlota e do Comendador, "visto ser [ele] o benfeitor desta menina". O casamento dá-se de forma simples na capela da própria fazenda e o jovem casal deixa o Grotão a cavalo não na direção de Porto Novo, onde o médico tinha residência, mas na direção oposta, no sentido da clareira que era freqüentada por Mariana na companhia da ama e onde a própria Carlota tantas vezes fora passear (p. 507). Muitas interpretações podem ser dadas para esse "desvio de rota", sem que uma necessariamente exclua a outra. Creio que uma delas passe pela atribuição simultânea à clareira do sentido simbólico de liberdade e de superação das contingências terrenas, pois Dona Mariana costumava procurar esse recanto relativamente distante para fazer as suas orações e certamente para escapar ao ambiente opressivo da casa-grande. O médico com quem Celestina se casara era pobre, mas é um profissional que trabalha por conta própria, não vinculado necessariamente às grandes propriedades rurais. É de se imaginar que aqueles dois sentidos não escapassem à noiva e que ela quisesse de algum modo confirmar o que havia sido estabelecido na capela da fazenda, submetida portanto àquele ordenamento, no interior do ambiente sagrado e livre da clareira, de algum modo "exorcizando" a influência da propriedade escravocrata da vida nova que então se iniciava. A impressão que fica é que narrador e autor não deixam de compartilhar a beleza e a verdade dessa iniciativa e é difícil imaginar que o catolicismo do autor não passasse por alguma restrição à instituição, aproximando-se talvez de um catolicismo ou cristianismo popular, mais próximo da natureza do que da sociedade, mais espontâneo do que preso a convenções, antes livre do que imposto.

Tendo chegado da Corte na companhia de Carlota e de dona Virgínia, Dona Maria Violante é, como foi dito, uma espécie de aspirante a agregada. Viúva, foi apresentada na fazenda como "muito amiga da família". Estava instalada no quarto de 
Dona Virgínia, mas, assim que viu Celestina desocupar o quarto quando de seu casamento, não perdeu tempo e foi a Carlota pedir para transferir-se para ele. Diante do olhar perturbado de Carlota, Dona Maria Violante apressa-se a dizer que não tinha medo de doença, pois é assim que interpreta o espanto sem palavras de sua interlocutora. Vinda da Corte, ela se mostra em muitos momentos dotada de uma ironia e mesmo um sarcasmo que não pareciam muito comuns entre as outras agregadas, cujo melhor exemplo se dá quando é oficializada, na presença do tabelião, a transmissão a Carlota de todos os bens ligados à propriedade paterna. A começar por Dona Virgínia, todos começam por beijar e parabenizar Carlota, e, ao chegar a vez de Dona Maria Violante, ela observa: "- Lastimo não estar presente o noivo, porque certamente é quem merece mais parabéns, depois do que acabamos de ouvir." E não satisfeita com essa referência tão direta e sarcástica, ao afastar-se ainda exclamou de modo a fazer-se ouvida: “- As partes contratantes... qual será a parte fornecida pela... outra parte contratante!" (p. 480)

Essas falas podem ser creditadas a um temperamento incapaz de calar os pensamentos mordazes que lhe ocorrem a despeito do risco de acabarem voltadas contra si mesmo, pois na verdade Dona Maria Violante estava em pleno movimento para se fazer aceita por Carlota como agregada. Isto nos permite entrever que há uma espécie de jogo a ser jogado em busca do resultado que se espera obter, a permissão para o estabelecimento na propriedade, se possível com um quarto só seu. O primeiro passo é obter um aliado, um outro agregado talvez, se possível um que desfrute de uma posição relativamente alta na hierarquia doméstica. Depois, envolver-se no conhecimento da casa, de cada um dos estabelecimentos que compõem a fazenda, e até mesmo das redondezas. Aos poucos, deve-se buscar o envolvimento nas atividades cotidianas, como a confecção de roupas seja para os proprietários, para outros agregados ou mesmo para os escravos, ou o preparo da casa, de bebidas e doces para a recepção de convidados, ou ainda a liderança dos escravos domésticos para a realização de tarefas periódicas - a usual contraprestação de serviços feita pelos agregados. E desse modo até que os vínculos estejam sólidos a ponto de ser considerado pessoa de casa. Sempre haverá, porém, o risco de se desagradar um dia ao proprietário, por isso todas as palavras e atos devem ser cuidadosamente medidos, e todo apoio deve ser dado às suas decisões, concorde-se ou não com elas, a não ser que se tenha conquistado alguma influência sobre ele, ou então que o parentesco seja real e tão próximo que permita algum nível de intromissão, ou finalmente que se tenha a garantia de um outro lugar para ser acolhido em caso de rompimento. D. Maria Violante nem sempre conseguia se 
calar e corria assim sérios riscos de ver baldados os esforços despendidos, embora deva também ter levado em consideração a relativa fragilidade de Carlota. Estivesse diante do Comendador, ela certamente não se atreveria a tanto.

No estudo já clássico que trata justamente da região e do período em que Cornélio Penna ambientou o seu romance, Maria Sylvia de Carvalho Franco, abordando a situação dos dependentes dos grandes proprietários de modo geral e não de agregados como estes que acabo de tratar, afirma que estavam expostos a uma alienação brutal, a uma dominação num certo sentido mais desumanizadora que a que pesava sobre os escravos, pois que esta não tinha como não ser explícita, e como tal não podia deixar de levar ao desejo de liberdade, ainda que encarada como impossível, ao passo que aquela outra não permitia a autoconsciência dela, pois dava como união harmônica entre homens formalmente livres o que era dominação do mais forte sobre o mais fraco ${ }^{22}$. Sem acolher integralmente essa tese, no mínimo passível de certa relativização, especialmente na comparação desfavorável dos dependentes com os escravos, acredito que se possa dizer que os agregados sofrem em alguma medida dessa alienação, pois muitas vezes assumem os interesses do senhor como se fossem os seus e colocam os escravos na antípoda do lugar em que procuram se situar, bem ao lado do senhor, sendo que a liberdade de que efetivamente desfrutam não parece tão mais expressiva que aquela dos escravos forros, como Libânia, que permanecem dependentes dos proprietários a despeito da liberdade formal. Se é difícil pensar numa completa falta de consciência dessa situação por todos os dependentes, pode-se reconhecer que de fato, crendo-se livres, acabam por não terem aspiração à liberdade, o que lhes tira mesmo algum sentido de humanidade. Tanto é assim que a única oportunidade que parecem vislumbrar ou a única meta que buscam perseguir, isto quando vêem sua situação

22 “... a admissão do dependente como pessoa é essencial para sua integração a uma ordem social que aniquila seus predicados de ser humano. Vê-se, por aí, a brutalidade da alienação a que está exposto. [...] Em suma as relações entre senhor e dependente aparecem como inclinação de vontades no mesmo sentido, como harmonia, e não como imposição da vontade do mais forte sobre a do mais fraco, como luta. Em conseqüência, as tensões inerentes a essas relações estão profundamente ocultas, havendo escassas possibilidades de emergirem à consciência dos dominados. // [...] Liberdade impossível [a do escravo] mas pelo menos desejada, o que devolve ao escravo, embora apenas como projeção individual, um sentido de humanidade. Para aquele que se encontra submetido ao domínio pessoal, inexistem marcas objetivadas do sistema de constrições a que sua existência está confinada: seu mundo é formalmente livre. Não é possível a descoberta de que sua vontade está presa à do superior, pois o processo de sujeição tem lugar como se fosse natural e espontâneo. Anulam-se as possibilidades de autoconsciência, visto como se dissolvem na vida social todas as referências a partir das quais ela poderia se constituir. Plenamente desenvolvida, a dominação pessoal transforma aquele que a sofre numa criatura domesticada: proteção e benevolência lhe são concedidas em troca de fidelidade e serviços reflexos. Assim, para aquele que está preso ao poder pessoal se define um destino imóvel, que se fecha insensivelmente no conformismo." $(O p$. cit., p. 94-5) 
ameaçada, é o encontro de um outro proprietário que os acolha na mesma situação de dependência.

Dos agregados de A menina morta, o que talvez mais se identifique com o fazendeiro é Manuel Procópio. Na ausência do Comendador, ele assume, para o bem e para o mal, o papel do proprietário de modo exemplar. Para o bem, no sentido de que se mostra dotado de um caráter nobre, justo e sempre correto, exercendo a administração da fazenda de maneira escrupulosa e honesta. Para o mal, porque - como vimos mostra ter adquirido o que quase se poderia chamar síndrome do feitor não fosse o fato de não se manifestar na violência que excede de muito a do proprietário de escravos, mas na desconfiança mais acentuada em relação ao caráter dos cativos do que a do próprio fazendeiro. De todo modo, ao final do romance, na abnegação que demonstra em relação a Carlota, no fato de não ter se recusado a cumprir suas determinações, por mais que discordasse delas e antevisse a ruína a que iriam levar a propriedade, do que ele próprio sofreria as consequiências, vemos que ele se sentia muito menos como agregado que como amigo da família e particularmente da filha do Comendador. A personagem de ficção quando de algum modo encarna a personalidade complexa dos homens não se deixa fixar, do mesmo modo que eles, em esquemas, em tipos fixos predeterminados, lugares em que muitas vezes gostaríamos de colocá-los. Manuel Procópio parece ser um desses, e dentre os agregados é dos que teria nutrido um sincero afeto pela menina, embora fosse justamente o que desse menos mostras disso, entre outros motivos por "seu orgulho de homem decaído até a condição de parasita" (p. 74), e teria transferido essa afeição integralmente, sem qualquer julgamento ou prejuízo, para Carlota. Na verdade, em relação à filha mais velha do Comendador, Manuel Procópio, não tendo mais ninguém de sua família, aparenta ter assumido o papel de pai de maneira ainda mais adequada do que assumira o de proprietário, apesar de se sentir, dado o avançado da idade, mais como um avô, assim como vira na menina morta uma netinha.

Carlota, por sua vez, sente-se muito melhor em sua companhia do que no das outras mulheres. É por isso que, quando decide visitar o túmulo da irmã na igreja de Porto Novo, é a sua companhia que solicita. Ele a atende prontamente, preparando as montarias para os dois assim que recebe o seu recado. Partem então na direção da igreja, e entre a alusão galhofeira dele à ausência da fiscalização de "velhas" e a menção de Carlota, no mesmo tom, de que teria havido, sim, fiscalização de sua partida e de que haveria "relatório a esse respeito", chegam até a balsa que deviam atravessar, não sem 
antes alguma reflexão de Manuel Procópio despertada por esse diálogo sobre a velhice, agora com um matiz melancólico e auto-irônico:

- Os dias que nos faltam, para nós, os velhos, parecem a belisária, esse dinheiro que os jogadores dão aos parceiros que perderam tudo, para continuarem a tentar a sorte, e a satisfazerem o seu capricho. Eu já recebi a minha parte, e já a gastei quase toda... (p. 410)

Ao chegarem finalmente à Igreja, entram por portas diferentes; Carlota dirige-se primeiro ao confessionário, e Manuel Procópio vai direto ao túmulo da menina. Algum tempo depois, estando ele a desfiar seu rosário, imerso em suas lembranças, sente alguém lhe tocar o ombro, "e viu, ao voltar os olhos já cobertos das cinzas da velhice, a mesma menina que vira morrer, agora revivida no vulto da moça alta e bela como os anjos: - É a mesma, - balbuciou ele - é ela que volta agora..." (p. 412) Carlota vê seus olhos cheios de lágrimas, mas não compreende suas palavras; ajoelha-se então ao seu lado e põe-se também a rezar. Nada mais é dito a não ser que subiram a cavalo a encosta de volta ao Grotão.

Como outros episódios do romance, encerrados em um ou, às vezes, mais de um capítulo, este como que se fecha em si mesmo, como um cromo ou um conjunto de cromos que apresentam cada um uma cena, formando, ao serem reunidos, um episódio não muito longo e extremamente plástico e ao mesmo tempo muito revelador do caráter dos personagens. É assim que nele acompanhamos os preparativos de Manuel Procópio para a partida, o modo como ele se coloca ao lado dos animais e prepara o cigarro sertanejo de "difícil feitura", jogando-o fora mal o tinha acendido ao ouvir o bom-dia de Carlota, depois a descida da serra a cavalo, feita com lentidão devido à época das chuvas, um ao lado um do outro, em meio a alguma conversa, feita contudo na maior parte em silêncio, a travessia da balsa e a chegada à igreja, o modo como Carlota, depois de apear, entra por uma porta lateral e se lança de joelhos ao confessionário, e Manuel Procópio, depois de prender os animais, entra pela outra porta e se dirige para perto do túmulo, depois a aproximação dela, sem que ele o notasse, tocando-o de leve no ombro, e os dois restam então ajoelhados lado a lado, para ao final retornarem ao Grotão em seus cavalos, percorrendo o mesmo caminho da vinda, mas agora em aclive.

Frau Luísa parece ser a única personagem assalariada dentro da casa-grande. Enquanto as agregadas abandonam a fazenda ao final do romance, ela é uma das poucas 
- ao lado de Manuel Procópio - a permanecer no Grotão. O seu objetivo era ajuntar dinheiro para um dia retornar à pátria, mas, a despeito de não haver até o fim qualquer referência sobre isso, é de se pensar que ela talvez nunca mais voltasse à Alemanha. $\mathrm{O}$ seu espírito germânico contrasta o tempo todo com o das outras mulheres, entrando eventualmente em choque com algumas delas, especialmente Dona Inacinha e Dona Virgínia. Muito do que se passa naquela propriedade, ela absolutamente não consegue entender, e é por seus olhos - e por seu espanto - que tomamos conhecimento de muito do que ali ocorre. Uma das coisas que mais lhe causa espécie é a existência de uma Senhora tão majestosa e tão altiva num lugar tão tosco e provinciano como aquele. Não compreende igualmente como nada lhe é revelado, como tudo ali se passa do modo mais misterioso e secreto, e não consegue conceber de modo algum coisas como a partida da Senhora. Tudo isso, porém, não implica a existência de um lugar que ela possa ocupar como assalariada e que a faça inteiramente dessemelhante das outras mulheres. É como se a estrutura da propriedade não permitisse a formação de qualquer classe distinta de proprietários, escravos ou agregados. Como ela estava muito distante em diversos sentidos dos dois primeiros grupos, acabava, com todas as diferenças, por se confundir com os últimos.

Dona Frau assim não só toma parte de várias das tarefas que cabiam àquelas mulheres como acaba por vivenciar com elas algumas "aventuras". Uma delas é o episódio do touro, no capítulo 35, que comporta um certo hermetismo que levou pelo menos uma crítica a uma interpretação simbólica dele. As três senhoras (Dona Maria Violante não havia chegado ainda à fazenda), depois de deixar o terreiro onde haviam confabulado com Joana Tintureira, que preparava as tintas com que seriam tingidas roupas para os escravos, viram-se diante de uma cerca viva, composta de espinheiros, seguida de uma vala. Dona Inacinha propôs então que pulassem a cerca para chegar ao pombal, para onde planejavam se dirigir, e foi o que fizeram. Mas ao chegar do outro lado deram com um grande touro parado a pequena distância delas e precipitaram-se em debandada para o fundo da vala, subindo pelo outro lado e pulando de volta a cerca. Ocorre que era muito mais difícil fazer o caminho contrário, pois a cerca elevava-se acima da vala a grande altura. Frau Luísa, que tinha tido enormes dificuldades para pular a cerca a primeira vez, não teve nenhum problema em fazer o percurso contrário, e apenas Celestina e Sinhá Rola se atrapalharam e só depois de caírem agarradas uma à outra puderam chegar do outro lado. A descrição do estado de espírito de Celestina é 
que parece conter um inequívoco sentido erótico e que prenuncia talvez o encontro do par amoroso que vai se dar mais à frente:

Celestina porém sentia-se presa pela terra, não podia erguer os pés que se tinham tornado pesados e mortos, e esperava a todo o momento por sobre sua cabeça surgir a sombra enorme do touro que se precipitava sobre ela e a esmagava com seu corpo agigantado. Em um relâmpago achou-se prisioneira, sozinha com o feroz animal de olhos de fogo e cauda erguida, então estendeu as mãos, apanhou as saias de Sinhá Rola e puxou-as. (p. 176-7, grifos meus)

Entretanto, se no caso de Celestina é possível pensar nesse tipo de antecipação, estendido às outras mulheres, solteironas ou viúvas, mesmo no caso da senhora Luísa, o susto provocado pelo touro talvez aluda à ambivalência de sua posição, entre o desejo e o medo, o desejo de liberdade, mesmo que inconsciente (ou sobretudo não consciente), e o pavor de se acharem livres mas desprotegidas, sem o teto do senhor para abrigá-las e sem a sua proteção. Essa interpretação também não prescinde do inegável conteúdo erótico da imagem: o desejo e o medo que se ligam à sua situação de dependência não é diverso do medo e do desejo de se entregarem a um homem. A decisão que há muito tempo já tomaram - a de submeter-se e não a de entregar-se - não implica que a tensão entre os dois pólos não continue latente no imaginário de cada uma delas.

\section{As tensões entre o latifúndio e o capital e as cisões entre os senhores do Grotão}

Essas e outras "aventuras" de Frau Luísa e das outras moradoras do Grotão como a ida de Sinhá Rola e Celestina até o pomar, em que o susto é provocado por um cisne no lugar do touro; a visita à enfermaria dos negros por todas elas, na companhia de dona Maria Violante; a excursão que fazem juntamente com Carlota até o riacho, ao tempo em que vão gradativamente figurando cada uma delas e em que se vão tecendo as relações entre elas, compõem - juntamente com momentos como aquele em que o Comendador percorre a propriedade a cavalo, ou aquele em que Dona Mariana se dirige à clareira, bem como aqueles outros em que se vêem os escravos envolvidos nas mais diversas atividades, sejam domésticas, ligadas à lavoura ou à manutenção daquela complexa estrutura - uma pintura impressionante, minuciosa e de grande plasticidade do latifúndio voltado para a produção do café. Localizado nas proximidades da cidade 
de Porto Novo, o Grotão tem esse nome devido ao relevo da região por que se estende, um imenso vale cortado pelo rio. Conta com um "exército" de cerca de 300 escravos, vigiados por uma "legião" de feitores e capatazes, e plantações de café numa extensão de terra que a vista não alcança.

O proprietário é o Comendador e parte da história de sua infância e juventude é contada no capítulo 18 em meio às recordações de Dona Virgínia, que fora até à porteira, pouco tempo depois da morte da menina, esperar o saco de correspondência. Aguardava uma carta do irmão do proprietário do Grotão, que recebera o título de Visconde e possuía uma propriedade no caminho da Corte, "e cujas grandezas lançavam uma sombra na testa do Senhor quando as visitas vindas da capital contavam o que em sua casa tinham visto e admirado". De posse da carta e prestes a lê-la, desfilam em flash-back imagens da própria história até que o narrador se detém no remetente da correspondência e no "prazer secreto" que tinha Dona Virgínia ao ler "aquelas cartas orgulhosas", e passa a partir daí a fazer um breve relato da vida dos irmãos. Há aqui uma confusão que nunca foi corrigida por Cornélio, talvez porque não tenha tido tempo ao falecer apenas quatro anos depois da publicação da primeira edição da obra e no mesmo ano em que foi publicada a obra completa pela Aguilar. Depois de falar no ódio que tinham um pelo outro, "desde meninos, no colégio", o irmão mais moço é figurado com todas as características que parecem denotar o Visconde:

\footnotetext{
o mais moço logo assumiu o primeiro lugar na classe e o professor o dava como exemplo ao mais velho, depois de acentuar com desdenhosa admiração a sua elegância e os seus penteados que serviam de modelo para os maiores, insubordinados. Todos sabiam que ele recebia jornais e revistas de Paris e falava francês como os parisienses, pois os preceptor que os educara na fazenda viera daquela capital e fizera dele o seu predileto, sem prestar mais atenção ao cadet, cada vez mais gordo e pesado. (p. 90)
}

Contudo, num trecho um pouco mais à frente, as coisas começam a se confundir: "O mais velho casara-se e fora logo para outra fazenda construída pelo pai, e tivera que pagar a diferença...” E finalmente, na página seguinte, a confusão está dada: 
O mais moço, que era o Comendador, e que se tornara homem esbelto e de nobre figura, desmentindo o menino obeso que fora, embarcou logo para a Europa onde procurou com sofreguidão o seu antigo professor que tanto o desprezara... Muitos anos mais tarde veio para o Grotão e casou-se. (p. 91)

De todo modo, o fundamental, além do ódio que nunca um deixara de sentir pelo outro, parece ser a diferença entre um proprietário mais cosmopolita, mais próximo da Corte, mais dado à sofisticação de sua propriedade nos moldes europeus e franceses, e um outro - o Comendador -, a despeito da vivência na Europa e de ter se tornado também um "homem esbelto e de nobre figura", mais interiorano, mais afastado da Corte, cuja propriedade, mesmo tendo todos os produtos de consumo que a riqueza podia comprar ao exterior, trazia em sua arquitetura, mobiliário, hábitos e costumes as marcas muito nítidas do interior do país. Assim, os dunquerques que, na carta, o Visconde diz ter comprado, "o mais rico trabalho de marqueterie que pudera encontrar na corte", contrastam com o que ele chama, de maneira escarnecedora, de "horrores matutos que [Dona Virgínia] está acostumada a ver aí nessa tapera”. E o próprio título de nobreza que ele ostenta parece objetivar o confronto com o singelo título de Comendador ${ }^{23}$ do irmão de modo a depreciá-lo ainda mais. É claro que essa distância da Corte e maior proximidade do interior não deve ser absolutizada. Além do que já foi dito nesse sentido, cabe lembrar que os filhos do Comendador estudam na corte e mesmo Carlota só retorna à fazenda devido à morte precoce da irmã. De todo modo, creio que nesse sentido também aqui se acentua uma característica importante e recorrente da literatura corneliana, o deter-se na fronteira entre dois mundos, o rural e o urbano, o campo e a cidade, o que ganha uma dimensão ainda mais ambivalente na medida do estabelecimento dessa propriedade de modo mais fundo no interior, pois o exterior, um pouco mais ou um pouco menos distante, está dado por meio da exportação do que é produzido na fazenda, já que toda a produção é voltada para o mercado externo, dos contatos com os comissários na capital, das atividades políticas e da educação dos filhos junto à Corte, sem falar nos diversos produtos importados que chegam à fazenda, incluindo revistas e livros em língua estrangeira. Essa mistura gera um descompasso que de algum modo ecoa uma vez mais o início de Raízes do Brasil, de Sérgio Buarque de Holanda:

\footnotetext{
${ }^{23}$ Segundo Maria Sylvia de Carvalho Franco, até mesmo um feitor e vendeiro, depois de relativo enriquecimento e de se tornar fazendeiro, podia chegar "à dignidade de Comendador" (p. 84.)
} 
A tentativa de implantação da cultura européia em extenso território, dotado de condições naturais, se não adversas, largamente estranhas à sua tradição milenar, é, nas origens da sociedade brasileira, o fato dominante e mais rico em consequiências. Trazendo de países distantes nossas formas de convívio, nossas instituições, nossas idéias, e timbrando em manter tudo isso em ambiente muitas vezes desfavorável e hostil, somos ainda hoje uns desterrados em nossa terra. (p. 3)

Mas parece ao mesmo tempo dar continuidade à autocrítica modernista, sem obviamente lançar mão da paródia, como bem o notou Maria Aparecida Santilli:

O postiço gosto europeu que decide sobre a vida na casa grande - destoante, no ambiente rústico da fazenda brasileira -, a educação das sinhazinhas em colégios europeus da Corte, no caso o de certa baronesa francesa, após a iniciação de uma "Frau" na esfera doméstica, complementada por leituras do tratado De l'education des femmes, com o respaldo dos livros de horas, como o Livre de piété de la jeune fille, ou Prière d'une ame coupable, mais repentante, são os índices de uma propriedade de classe de cultura, como o são os das vaidade femininas satisfeitas nos tecidos franceses da loja de Catherine Dazon, costurados pelas modistas Rippol ou Madame Gudier, segundo os modelos da Mode illustrée. ${ }^{24}$

Por outro lado, essa ambivalência entre o interno e o externo, entre o campo e a cidade particulariza-se em A menina morta numa situação de grande complexidade, a um só tempo muito específica e não desvinculada de um contexto mais geral. Do mesmo modo como afirma Maria Sylvia de Carvalho Franco, ao tratar da crise dessa “velha civilização do café", que Cornélio Penna traz para o seu romance, ser equivocada a noção de que teria havido "dois tipos diferentes de sociedade, em oposição: uma escravista e tradicional e outra capitalista e moderna”, mas que havia ao contrário uma “coerência deste novo mundo com o velho de além-mares",25, não é correta a visão de que campo e cidade, correspondendo cada um deles aos grupos "escravista e tradicional / novo mundo" e "capitalista e moderna / velho mundo", se oponham como pólos inconciliáveis. O oposto é que parece mais próximo da verdade: um dependia do outro, a produção de riqueza estava no campo, mas o comércio e a exportação tinham como centro a cidade; o produtor dependia do comissário e vice-versa; boa parte do que se produzia e se comerciava na cidade se devia à existência do campo, desde o comércio

\footnotetext{
24 “A menina morta de Cornélio Penna: O nacionalismo e o intimismo", p. 78.

${ }^{25}$ P. 230.
} 
fundamental de escravos e animais até o estabelecimento de escolas, onde os filhos dos grandes proprietários vinham estudar, enquanto era só na cidade que o campo podia obter tudo isso e o que mais precisasse e não pudesse ou não lhe interessasse produzir. É preciso ter em mente esse vínculo para que se evite, por um lado, a idealização do campo $^{26}$, especialmente quando se quer fazer por contraste a crítica da cidade, por outro, para que não se faça nesse mesmo movimento a associação entre campo, tradição e feudalismo, e entre cidade, modernidade e capitalismo. Raymond Williams mostrou à exaustão, em seu clássico e brilhante estudo, o equívoco e a persistência desse modo de ver a história do campo e da cidade. A ligação entre o capital e o campo deu-se há muito e é mesmo anterior ao desenvolvimento das cidades no auge do capitalismo, que é por sinal um fenômeno em alguma medida decorrente do primeiro. Assim, a despeito de certos traços que fazem do proprietário uma espécie de senhor feudal e da propriedade possuir algumas das características de um feudo, como certa auto-suficiência em relação a boa parte de suas necessidades, é o latifúndio uma empresa que só pode ser concebida no interior do sistema capitalista ${ }^{27}$. É certo que as sucessivas crises desse modelo e a crise final que levou à derrocada da propriedade fundada no trabalho escravo estão relacionadas à mistura e às tensões entre esses dois mundos. Do mesmo modo, a crise do Grotão, se teve como estopim o relacionamento entre Mariana e Florêncio, como imagino, e a morte da menina, não pode ser desvinculado da tensão entre cidade e campo, entre sistema escravista e produção capitalista, entre escravidão e liberalismo, sem contar as tensões internas de uns e outros, que independem de qualquer mistura mais explosiva. Assim, a desumanidade da escravidão por si só já deve provocar atritos suficientes que vão aos poucos abalando a estrutura do sistema que nela se assenta, e o mesmo talvez possa ser dito do capitalismo.

No caso do Grotão, essas tensões são figuradas, entre outras coisas, nas divisões internas dos personagens e na cisão entre o Comendador e Mariana. Esta, por seu turno, "cederá" seu lugar a Carlota, que até o momento de identificação com a mãe ocupa o

\footnotetext{
${ }^{26}$ Por mais impensável que isso possa parecer no caso da grande propriedade escravocrata, mas Raymond Williams mostrou como isso ocorreu ao longo de toda a história da Inglaterra mesmo nos casos em que a realidade do campo era a mais dura e brutal que se possa imaginar para os trabalhadores rurais. ( $O$ campo e a cidade: na história e na literatura.)

27 "Os eventos sem precedentes do século XIX, que fizeram da Inglaterra uma sociedade predominantemente industrial e urbana, com a agricultura transformada em atividade marginal, seriam inexplicáveis e impossíveis sem este desenvolvimento colonial.” (Id., p. 376) Alfredo Bosi estuda as ligações estreitas entre o liberalismo e o capital e a escravidão, que absolutamente não se restringiram ao Brasil: "It was freedom to destroy freedom: dialética do liberalismo no seu momento de expansão a qualquer custo.” (“A escravidão entre dois liberalismos”, Dialética da colonização, p. 209.)
} 
lugar da menina morta. Já se procurou mostrar aqui o modo como essas três personagens femininas se confundem e são confundidas por diversos personagens no romance, dos escravos aos agregados. Carlota parece inicialmente substituir a menina morta até adquirir consciência do horror da escravidão, o que a leva à perda da inocência e a assumir nesse passo o governo da casa de maneira indiscutível, sendo a partir daí identificada à figura materna. Certamente não deve ser casual o fato de, no pólo oposto ao Comendador, se alternarem três figuras femininas. Há aí nitidamente uma polarização entre os elementos masculino e feminino. Dentro desse sistema patriarcal, o Comendador encarna em si o elemento masculino por excelência. O que poderia parecer uma tautologia não o é se considerarmos o sem-número de exemplos em que esse representante era encarnado por uma mulher ${ }^{28}$. O desempenho dele nesse papel é absoluto, não delegando e nem mesmo dividindo a tarefa de percorrer diariamente as terras cultivadas, acompanhando em pessoa o trabalho dos escravos, supervisionado pelos feitores, que por sua vez se subordinam ao administrador. Em casa essa autoridade não seria menor. Nenhum dos agregados ousa, por exemplo, dirigir-se à sala de jogos sem que ele tome a dianteira. Quando após o jantar isso não acontece, não há jogo. Respeito é uma palavra relativamente amena para designar o que as agregadas manifestam diante dele; temor seria talvez mais adequado. Elas nunca o contradizem e nem mesmo chegam a expressar o que pensam de fato sobre o que quer que seja quando isso implica minimamente alguma discordância com o que ele pensa. Apenas Dona Virgínia, parente muito mais próxima que as outras, ousa provocá-lo, assim mesmo de modo relativamente indireto, com alusões à grandeza do Visconde que, por contraste, diminuem o que o Comendador possui. Quanto a Celestina, parente de Dona Mariana, talvez fosse ainda mais adequada a utilização da palavra pavor para descrever o que sente diante do marido da prima, e em nenhum momento isso fica tão claro como no episódio em que o Comendador a traz pelo braço até a sala de refeições, fazendo com simplicidade o que era absolutamente incomum, encobrindo com um gesto de cortesia e refinamento a que ninguém ali estava acostumado o que era na verdade uma proibição e

\footnotetext{
28 "Esses papéis informais, improvisados, têm um sentido importante na desmistificação do tão discutido sistema patriarcal brasileiro. Por tradição e costume, a divisão de funções e de tarefas entre os sexos era rigidamente à parte e bem demarcada, estabelecendo-se esferas de atuação complementares e nitidamente separadas. De fato, a ausência do homem ou sua presença intermitente impunha com freqüência não tanto a divisão como a alternância ou troca de tarefas: assumir papéis masculinos não era muito excepcional." (Maria Odila Leite da Silva Dias, Quotidiano e poder em São Paulo no século XIX, p. 53.) No próprio Cornélio, temos o exemplo de D. Ana, em Dois romances de Nico Horta, e mesmo em A menina morta D.Virgínia parece ter desempenhado esse papel antes de vir para o Grotão, sem falar na Condessa, mãe do noivo de Carlota.
} 
uma reprimenda. É que ele acabava de sair de seu quarto quando deu com Celestina prestes a entrar no quarto de Mariana, e a relação entre marido e mulher já estava num ponto em que ele parecia contar com o isolamento dela: "O Comendador levou Celestina até o seu lugar, fê-la sentar-se, como se não tivesse notado a perturbação que fazia tremer todo o corpo da pobre moça e depois de rezar rápida oração fez sinal para que todos começassem a servir-se.” (p. 165)

Essa oração rápida feita pelo Comendador não é o primeiro momento no romance em que podemos notar a sua religiosidade, apesar das recorrentes alusões ao capelão que se retirara da fazenda "como se fora expulso", fato que de algum modo parece relacionar-se com as desavenças do casal. Muito mais importante e extenso é aquele outro momento no início do capítulo 28 em que o Comendador dirige a prece na capela:

Era sexta-feira essa noite e Dona Virgínia ao caminhar pelo corredor ouviu de longe as vozes graves dos escravos em resposta às orações, ditas em tom abafado pelo Senhor e pelas outras pessoas. Apressou o passo e foi pé ante pé para a sala grande da capela. Com viva surpresa verificou ser o fazendeiro em pessoa quem dirigia a prece da noite, e ajoelhar-se diante do oratório com seu grande lenço branco nas mãos. Há muito tempo ele não vinha mais e recolhia-se ao quarto sem que ninguém o visse passar e lá já encontrava a Senhora recolhida logo depois do jantar. Ainda na porta, Dona Virgínia viu o grupo formado por ele, poucos passos à frente dos outros e logo seguido pelos quatro homens hóspedes então na fazenda. Mais atrás, as senhoras vestidas todas de negro, e formavam a vanguarda das mucamas de dentro, uniformizadas de xadrezinho preto e branco com as cabeças ocultas pelos lenços em harmonia com as rendas das mantilhas postas nos cabelos das parentas e da governante. A entrada do quadrado abria-se sobre o alpendre onde ficavam as pretas velhas seguidas pelas crianças e pelos escravos mais antigos, cercados pelos feitores, e lá no fundo, na escuridão apenas cortada por duas grandes lanternas de luz vermelha, a multidão dos escravos. O Comendador, com a voz um pouco presa, dizia a primeira parte das orações e todos respondiam em coro, indo o eco das respostas até os muros do enorme pátio, e de lá erguia-se então no silêncio desmedido da noite para o céu onde fervilhavam milhares de estrelas em toda a sua pompa. Talvez muito longe, na estrada deserta, algum viajante solitário ouvisse aqueles cânticos e julgasse escutar vozes do céu, pois até lá chegariam suavizadas pelas distância em cansada melodia, arrastada em notas de serena angústia. (p. 143-4) 
É muito provável que Cornélio Penna tenha se inspirado em algum relato, oral ou escrito, ou mesmo algum quadro ou gravura, feitos por alguém que acompanhou uma dessas missas numa fazenda que utilizava larga mão-de-obra escrava. A disposição da multidão rigorosamente de acordo com a posição no interior daquele sistema é impressionante. Longe de dividir-se apenas em homens livres e escravos, a hierarquia comporta divisões e subdivisões em cada um desses grupos: primeiro, logo após o proprietário, vêm os hóspedes do sexo masculino; depois, as mulheres agregadas, seguidas pelas mucamas de dentro; a seguir, as pretas velhas, as crianças e os escravos mais antigos; e, finalmente, os escravos do eito, imersos na escuridão ao fundo. Mas não é só nesse sentido que a imagem dessas orações noturnas representa homologicamente a estrutura social do latifúndio. A repetição por todos, sem exceção, das orações pronunciadas pelo proprietário aludem à sua autoridade indiscutível e à obediência que todos ali deviam prestar-lhe. A menção a um possível viajante solitário que poderia da estrada ouvir aqueles cânticos e julgar que se tratasse de vozes celestes, pois a distância as faria soar paradoxalmente como "notas de serena angústia", pareceme, por um lado, terrível ironia que atribui ao celestial o que na verdade provém de um locus infernal, e por outro, alusão ao distanciamento, seja no tempo, seja no espaço, que acaba por amortecer os horrores da escravidão. E, finalmente, a verdadeira crença que o Comendador parece de fato possuir não implica em absoluto o sentimento de qualquer contradição dela com a escravização de tantos homens. Sempre se podia deixar de reconhecer a sua humanidade, assim como era sempre possível argumentar que o que se estava fazendo a eles era na verdade um bem para eles próprios, como o proporcionarlhes o conhecimento da fé cristã, pois do contrário ficariam relegados às suas crenças bárbaras e fetichistas. A mesma crença cristã não impediu o assassinato de Florêncio, mas não se fez necessário aqui o uso de argumentação de qualquer tipo, pois a versão do suicídio se colocou, com vantagens, no lugar do mais capcioso dos argumentos ${ }^{29}$.

\footnotetext{
29 "No século XVII e mesmo no XVIII não houve senhor branco, por mais indolente, que se furtasse ao sagrado esforço de rezar ajoelhado diante dos nichos: às vezes rezas quase sem fim tiradas por negros e mulatos. O terço, a coroa de Cristo, as ladainhas. Saltava-se das redes para rezar nos oratórios: era obrigação. Andava-se de rosário na mão, bentos, relicários, patuás, ... [...] Em Cantagalo, na casa-grande do fazendeiro Joaquim das Lavrinhas, Mathison ficou encantado com o patriarcalismo do dono da casa, ajoelhando-se diante de todo o pessoal da fazenda - parentes, agregados e escravos - para pedir a benção de Deus e a proteção da Virgem Maria. E nada lhe pareceu mais digno no brasileiro colonial que o fato de ter sempre em sua casa lugar destinado ao culto divino. Sinal de 'respeito pela religião', concluiu. E não esqueceu de salientar a observância, pelos negros, dos ritos da igreja.” (Gilberto Freyre, Op. cit., p. 602.)
} 
No pólo oposto a esse tipo de culto obrigatório, coletivo, hierárquico e institucional $^{30}$, vinculado mais às manifestações exteriores que ao foro íntimo, encontrase o culto prestado por Dona Mariana na clareira. Já foram feitas algumas menções a esse espaço quando procurei tratar do casamento de Celestina, mas agora pretendo aprofundar as reflexões sobre o modo como a clareira se coloca na antípoda da capela. Mariana parte numa caleça guiada por Ângela. O que mais parece adequado para caracterizar a sua mucama de quarto é a fidelidade absoluta à sua Sinhá, chegando - por exemplo - a atrair para si o ódio que Dona Virgínia votava a Mariana. Permanece o tempo todo ao lado dela, sendo a sua única companhia quando abandona o Grotão. Ao final, com ela retorna, não permanecendo contudo na fazenda, pois que a filha iria lhe tomar o lugar. É quase então como uma sombra que ela acompanha Mariana à clareira, passando por alguns grupos de escravos vigiados de perto pelos feitores, envolvidos na colheita dos "cafezais intermináveis", sem lançarem um olhar sequer para eles. Depois de algum tempo, adentram na mata:

Mas sem ser chamada, sem que ninguém ousasse invocá-la, veio logo a mata invasora, sempre pronta a tudo devorar, a zombar dos esforços do homem, e foi em verdadeiro túnel crepuscular de verdura que o rápido veículo entrou, sempre em veloz disparada.

Andaram ainda bastante tempo sob a penumbra das árvores entrelaçadas por sobre o caminho, que de lá do alto deixavam cair grandes cortinas franjadas de parasitas e cipós aos balanços no ar, e ameaçavam fechar a passagem. Inopinadamente abriu-se diante delas a clareira, toda iluminada pelo sol, aprisionada pelo silêncio absoluto que ali reinava. Foi então que a Senhora segurou o braço da escrava, e fez-lhe sinal de suspender a corrida. De onde estavam, avistava-se pequena palhoça muito rústica que parecia mocambo de tomador de conta de lavoura, mas quando se via de mais perto percebia-se ter tido outro destino... Grande cruz de madeira fora colocada de encontro à palha do fundo e nas pedras que a rodeavam via-se ter o sebo de velas primitivas deixado a sua marca negra e fuliginosa. Desceram ambas e para lá se dirigiram através das plantas e do alto capim de tudo vencedor. A Senhora ajoelhou-se, rezou por alguns minutos e

\footnotetext{
${ }^{30}$ A ausência de um representante oficial da instituição da Igreja Católica não implica de modo algum a recusa a esse culto de um caráter institucional, pois não só é realizado de acordo com todas as regras da igreja, numa capela doméstica, mas reconhecida por ela, como obteve autorização expressa para a realização dessas cerimônias sem a presença de um pároco.
} 
depois sentou-se na pedra maior. Ficou muito calada, sem prestar atenção à mulata, que de mãos cruzadas na cintura a contemplava com tristeza. (p. 156)

Assim como à multidão daquele culto contrapõe-se a solidão das orações da senhora; ao institucional e obrigatório, o espontâneo; à exterioridade, a intimidade; à capela incrustada na casa-grande, com suas imagens e mobiliário próprios à devoção católica, opõe-se uma simples choça com uma cruz de madeira. Ali, em lugar de uma escrava, Ângela (angelus, anjo) - de quem em nenhum momento se solicita a participação nas orações e a quem muito menos se obriga a rezar - parece antes uma protetora da Senhora, pronta para demonstrar piedade e compaixão por ela. A distância entre os dois momentos, tão próximos dentro do romance, não se dá apenas por essas enormes diferenças, mas é marcada espacialmente. Não é somente após um longo percurso, como é apenas depois de serem ultrapassadas as plantações de café, onde labutam os escravos sob o chicote dos feitores, ao entrar na "mata invasora", "a zombar dos esforços do homem", que se chega à clareira. A inversão irônica assume o discurso do masculino e da ordem patriarcal já que do ponto de vista da natureza e do feminino é, ao contrário, o homem que invade a mata, o mesmo homem que escraviza seu semelhante. A clareira, porém, não é a mata, mas uma espécie de limite onde a própria natureza estaca interdita: "O silêncio era absoluto, e até os pássaros pareciam evitar aquele lugar taciturno, onde a sensação de vazio e de ausência se fazia sentir de forma insidiosa, que subia do coração ao cérebro, sufocando primeiro a garganta, como nos envenenamentos da beladona". (p. 157) Tudo isso somado à figura solene de Dona Mariana, que mesmo ali parece, como na casa-grande, mais levitar do que caminhar, alheia ao que acontecia à sua volta, faz com que a escrava sinta arrepiar-se de medo, que chega ao paroxismo diante de uma gargalhada louca que soa ali perto, "sobre-humana, infernal", que ela descobre pouco depois ser na verdade o relincho do cavalo que as trouxera até a clareira e, descontrolada, acaba por chicotear o animal.

Ao buscar a fuga da opressão imposta pela estrutura patriarcal, só um caminho parece ter restado a Mariana: a loucura, que surge nesse momento em sugestões e alusões veladas para mostrar-se inteira ao final do romance. Entre a natureza e a cultura, lugar do vazio e da ausência, representada por essa clareira distante da propriedade, mas em que a mata também não penetra, surge a insanidade - tema quase onipresente na obra corneliana -, mas que não tem em Cornélio Penna um sentido exclusivamente negativo. Dentro da positividade que nela se pode encontrar, destaca-se o fato de 
permitir àquele que é tomado por ela furtar-se a boa parte das constrições sociais. É assim que gradativamente Dona Mariana vai se afastando de tudo que a ligava ao papel de senhora do proprietário, recolhendo-se cada vez mais aos seus aposentos, para ao fim até mesmo abandonar a propriedade. ${ }^{31}$

\section{Carlota: da lenta aprendizagem até a "visão" dantesca; libertação e ruína}

A liberdade de dona Mariana, é verdade que adquirida a altíssimo preço, é semelhante em alguns aspectos à da menina morta, e é aqui que de algum modo faz-se possível relacionar a mãe à filha mais nova. Aos loucos e às crianças costuma-se permitir o que em geral se proíbe taxativamente aos adultos "normais". Além da criança, só o louco seria talvez capaz de dizer que o rei está nu sem medo de qualquer sanção, embora se deva reconhecer que a loucura da senhora era de um tipo inteiramente avesso ao riso, uma alienação que fazia com que ela parecesse antes um espectro que uma criança. Antes da loucura, era com a menina que ela fazia alguns passeios, embora fosse Bruno e não Ângela quem nessas ocasiões dirigia o carro, que fazia trafegar "pelos campos sem cultura", pois sabia que a senhora não gostava de ver o trabalho no eito. Essa aversão à vista dos escravos, embora não seja explicitado o motivo, pode ter como razão a incapacidade de aceitação da naturalidade da escravização daqueles homens. É certo que dona Mariana convivia com os escravos dentro de casa, mas nesse caso as marcas exteriores da escravidão tinham seus contornos como que esfumados pela proximidade enganosa entre brancos e negros. É tanto por ser ainda criança como por herdar parte desse sentimento materno que a filha mais nova, assim como Carlota na mesma idade também o fizera, distribui chapinhas de metal e sorrisos para as negras.

Aquilo que no caso da menina morta e de dona Mariana parecem sentimentos tênues e vagos irá tornar-se para Carlota uma questão com que terá inescapavelmente de se defrontar, decidindo-se por fim, diante da transmissão de toda a propriedade para o seu nome, pela libertação dos negros. Se há que levar em conta uma possível influência materna, como a que inferimos em relação à irmã, não é possível deixar de perceber que a motivação principal foi construída por uma história de vida de que grande parte do romance se ocupa em narrar. Nele, essa história começa com a chegada de Carlota ao

\footnotetext{
${ }^{31}$ V. cap. 4.
} 
Grotão, vinda da Corte, embora haja menções anteriores ao seu nome, como no momento em que o Comendador comunica aos moradores da fazenda a decisão de trazer a filha de volta e em que encarrega Dona Virgínia da tarefa de buscá-la juntamente com Manuel Procópio.

O tão esperado retorno de Carlota é uma decepção para todos, pois, tendo caprichado nos preparativos para sua recepção, providenciando os doces e as frutas de sua preferência e as flores que mais deviam agradá-la, os moradores parecem não levar em nenhum momento em consideração que ela poderia estar aflita demais com a ausência da mãe e do pai, com os problemas de que devia estar de algum modo informada ou pelo menos com a desconfiança de que algo de muito grave acontecia com sua família, para usufruir daquilo que haviam preparado para ela. Antes de estarem de fato preocupados com ela, pareciam na verdade interessados tão-somente em agradar a futura herdeira da propriedade e dela esperavam apenas que desempenhasse a contento seu papel de filha que retorna feliz ao lar. Ela, porém, simplesmente se recolhe ao quarto onde fica até o dia seguinte e só sai para o almoço por insistência de Dona Virgínia, retornando imediatamente depois de terminada a refeição. O seu convívio é feito quase exclusivamente com Libânia e é só aos poucos, especialmente com o retorno do Comendador, que ela vai se fazendo mais presente, mas aí vão começar os atritos com Dona Virgínia, que dificilmente aceita que a filha de Mariana tome dela o governo da casa, agora que finalmente encontrara ocasião para trocar a posição subalterna de dependente para a de Senhora a quem todos deviam se subordinar.

O Comendador já havia decidido casar Carlota com o filho do Conde do Meal, que era Primeiro-Ministro e obviamente vivia na Corte, mas tinha uma propriedade vizinha ao Grotão, onde residiam a mulher e o filho, de quem era dito que brevemente seria Barão. Os detalhes do casamento, que deveria ser realizado sem grande perda de tempo, seriam acertados entre o Comendador e a Condessa, pois seu marido estava envolvido com uma crise na Corte e a formação de um novo gabinete. As razões desse açodamento seriam a situação conjugal insustentável do Comendador e provavelmente a complicada situação financeira do Conde, que é só o que poderia explicar a aceitação por parte de uma família tão nobre de casar o filho com a filha de pais separados por um motivo que devia ser escandaloso e que inevitavelmente provocava rumores. Contudo, depois das duas primeiras visitas da condessa e do filho ao Grotão, o Comendador acaba tendo de também partir para a Corte, ao receber a notícia de que o filho estava doente e parecia ter contraído febre amarela. O tempo vai passando, as notícias do pai não 
chegam a Carlota ou chegam vagas e imprecisas, muitas vezes de modo indireto. Enquanto isso, ocorrem alguns outros encontros entre a Condessa, o filho e a noiva. O noivo, João Batista, pouco depois da primeira visita com a mãe, já se dera a conhecer ao presentear Carlota com um cavalo adestrado. Carlota logo descobre decepcionada o truque fácil para fazer com o animal "desse" uma resposta positiva às perguntas que lhe faziam. Mas, ao descobrir ao mesmo tempo que o cavalo se chamava Satã, não foi de imediato que sentiu "a insensibilidade, a indelicadeza, a falta absurda de ter sido dado aquele nome à dádiva a ela ofertada com tamanha ostentação" (p. 334). Muito mais decisivo para o futuro de Carlota, e mesmo para o futuro do Grotão, foi contudo a terceira visita do noivo, marcada por um acontecimento estarrecedor. É em todo o livro um dos episódios mais terríveis, mais reveladores da crueldade insana, da tremenda violência empregada por aqueles que no mais se dedicam a atividades cerimoniosas e corteses, ainda que essas cerimônia e cortesia sejam apenas a camada superficial a encobrir o que é na verdade um negócio ${ }^{32}$, e do modo muitas vezes passivo, conformado e impotente com que as vítimas - constrangidas a uma condição inferior mesmo à do animal, pois que neste o instinto sempre o faz reagir - recebem na carne o efeito dessas manifestações que brutalmente desmentem essa civilidade e polidez exteriores:

Quando chegou no alpendre, viu o moço já apeado do animal em que acompanhara a vitória e estava agora junto da boléia de onde assistia o trintanário tirar pesada caixa de pinho. Ele não pressentira estar sendo visto pela noiva, pois achava-se de costas, e Carlota pode ver bem a dificuldade com a qual o negro retirava a bagagem, e só compreendeu o acontecido quando viu o escravo receber em cheio o caixote sobre os pés, pois não o conseguira reter na sua queda brusca, ao se romperem as correias que a prendiam às grades do assento. Mais rápido ainda, o moço agarrou o preto pelo peito da japona por ele vestida e fustigou-o às cegas em furiosos golpes com o chicote que trazia na mão direita. $\mathrm{O}$ trintanário recebeu as chicotadas que deviam marcar profundamente a sua carne, mal protegida pela pobre libré por ele envergada, sem qualquer gesto de defesa, sem experimentar fugir ou se proteger, nem mesmo tirar o pé debaixo do engradado, a esmagá-lo.

${ }^{32}$ É com receio e vergonha de ser vista que Carlota ouve, sem saber exatamente quem a tinha pronunciado, pois partira de um grupo de homens que haviam acabado de presenciar a assinatura do contrato de seu casamento, dentre eles o próprio Comendador e o senhor Manuel Procópio, a frase que confirma com todas as letras esse caráter da união: “- Bem, vamos dormir, pois o negócio está feito!” (p. 349) Mas pouco antes ela própria já sentira que era exatamente disso que se tratava: “... era [o pai] agora um homem estranho que tinha diante dela, a afastá-la com impaciência de seu caminho, e lhe parecia ser também escrava cuja venda estava em negócio, mediante condições impossíveis de serem imaginadas..." (p. 343) 
Mantinha os olhos muito abertos sem expressão, e era semelhante ao animal resignado à dor por ele sabida inevitável, e entregava-se à vontade do dono sem restrições, esquecido até dos primeiros instintos das criaturas. (p. 420) 3 $^{33}$

A continuidade da narrativa mostra o espanto imensurável de Carlota e o impacto que essa cena nela provocara ${ }^{34}$, ao mesmo tempo em que demonstra que, o que quer que tenha ocorrido, a encenação da mentira social tem que continuar. É só depois de algum tempo, em que aproveitou para enxugar o suor do rosto e se recompor, que o noivo dáse conta da presença dela e vem "ao seu encontro iluminado pela alegria e com a naturalidade dos noivos", e o escravo, depois de também se arrumar como pôde, passa por ela e a saúda com jovialidade, como se nada tivesse acontecido. E então João Batista lhe informa ser aquele caixote uma lembrança que sua mãe lhe autorizara a oferecer a ela, dirigindo-se ambos imediatamente para a sala, onde foram recebidos alegremente pela Condessa e pelas mulheres da casa.

Como no conto machadiano que termina sem que o leitor saiba o destino de Damião $^{35}$, pois que não era essa a questão central do conto, mas a escolha que ele devia fazer - e fez, a despeito da breve hesitação - de entregar ou não a vara a Sinhá Rita, para que ela castigasse Lucrécia, não ficamos sabendo aqui o conteúdo daquela caixa, pois essa é também uma questão menor. O fundamental é a lição que Carlota aprende e que terá continuidade em outros acontecimentos por ela vivenciados. Nesse sentido, igualmente importante foi a visita que fez à sala de suplícios na senzala, mas pouco antes disso, ao acordar durante a madrugada e deparar com Joviana e Libânia, que dormiam profundamente junto à entrada de seus aposentos, deitadas em esteiras estendidas diretamente sobre o chão, "envolvidas em cobertas miseráveis", pôde ver aquelas mulheres, que a serviam de modo tão dedicado, como nunca as vira antes, em toda a sua miséria, enquanto ela vivia em meio a tamanha riqueza. Tendo perdido o

\footnotetext{
${ }^{33}$ Esse episódio faz lembrar um conto de Tolstói, "Depois do baile", em que toda a paixão de um jovem por uma bela moça começa a desvanecer quando - logo depois de um magnífico baile, em que dançara muito com ela e a tinha visto dançar com o pai, um coronel elegante e esbelto -, ao perambular pela cidade na madrugada daquele mesmo dia, depara com um grupo de soldados, comandados por esse mesmo homem, o pai de sua amada, e o vê esbofetear impiedosamente um soldado porque ele não demonstrara suficiente firmeza ao vergastar um tártaro que, sob suas ordens, todos submetiam a um terrível castigo, cruel e desumano. Vemos aí o mesmo contraste entre a polidez e o refinamento social, de um lado, e a selvageria e a crueldade, de outro, encarnados pela mesma pessoa.

34 "Carlota teve vontade de correr, de gritar, de rasgar o seu vestido, mas apenas pôde manter-se agarrada ao balaústre do alpendre e tinha certeza de que se dele desprendesse os dedos cairia no chão sem amparo." (p. 420)

35 "O caso da vara", Páginas recolhidas. V. o ensaio de Alcides Villaça sobre o conto: "Querer, poder, precisar: 'O caso da vara' ", Teresa - revista de literatura brasileira, n. 6/7.
} 
sono, caminha pela casa, vai até a capela, e depois ao quadrado. Lá, ouve gemidos que pensa vir da enfermaria dos negros, mas vê que estava enganada quando se dirige para a varanda e olha para dentro de uma das aberturas:

Lobrigou, depois de fitar os olhos, a sala muito longa e vazia. Depois, percebeu alguns móveis estranhos com pontas que furavam o ar de forma esquisita, e logo compreendeu mais do que viu ter sido uma árvore inteira deitada junto da parede do fundo. O ronco ritmado e muito regular partia dali, mas às vezes destacava-se dele o lamento profundo e sombrio por ela já escutado e agora ouvido distintamente. Procurou a porta, e ao achá-la deu volta à taramela simples que a prendia, e entrou na quadra atijolada e foi até a parede fronteira. Realizou então serem escravos no tronco, e lembrou-se a sorrir das histórias de que a menina morta ia "pedir negro"... Mas, o sorriso gelou-lhe em seus lábios, porque agora via o que realmente se passava, quais as consequiências das ordens dadas por seu pai e como aqueles homens velhos, os feitores de longas barbas e de modos paternais, que a tratavam com enternecido carinho, cumpriam e ultrapassavam as penas a serem aplicadas. Sabia agora o que representava o preço dos pedidos da menina morta, que a ela custavam apenas algumas palavras ditas com meiguice. E teve ódio da criança ligeira de andar dançante, a brincar de intervir, vez por outra, em favor daqueles corpos que via agora contorcidos pela posição de seus braços e pernas, presos no tronco, e cujo odor de feras enjauladas lhe subia estonteante às narinas. Parecia-lhes mostruosa a cena, no entretanto muitas vezes vívida em sua memória, e tantas outras contadas pelas mulheres e irmãs daqueles agora diante dela, sem sequer a olharem, se estavam mesmo acordados, na certeza de ser ela alguma aparição infernal, talvez alguém mandado para averiguar se sofriam tanto quanto fora determinado... (p. 475)

Trata-se indiscutivelmente de uma cena pavorosa, cuja narração convoca diversos sentidos para a sua apreensão. As alusões que remetem a cada um desses sentidos surgem em sequiência, como não poderia deixar de ser em um texto narrativo, mas é como se adquirissem simultaneidade ao ficarem ecoando, dado o terrificante da descrição, à medida em que é feita a leitura: a visão daqueles corpos retorcidos, a audição do ronco ritmado e dos gemidos por eles produzidos, o cheiro nauseante de “feras enjauladas". É uma cena verdadeiramente dantesca, sufocante e insuportável, que como nenhuma outra remete ao caráter infernal e demoníaco do sistema escravista. Não 
é de causar espanto o tremendo choque que ela teria provocado em Carlota.Todavia, essas mesmas cenas horrendas de escravos no tronco também estavam vívidas na memória, pois não só Carlota as devia ter visto antes tal como agora, como as mucamas, que viviam sempre tão próximas dela, lhe contavam o que ali se passava e descreviam o sofrimento daqueles que eram seus maridos ou irmãos. Assim como o narrador afirma, no momento em que ela contempla as duas amas deitadas, que "nunca as vira assim e se as tivesse visto antes, não sentiria o aperto que lhe fez parar a respiração...", o que teria acontecido a Carlota para que essas cenas lhe causassem agora tamanho pesar? Por que nunca desconfiara que aqueles "feitores de longas barbas e modos paternais, que a tratavam com enternecido carinho", eram os algozes sádicos e impiedosos dos negros? Como nunca pudera perceber que a autoridade do pai era a responsável pelo sofrimento inenarrável dos escravos? Como diante de várias outras questões, não parece possível aqui apontarmos de modo indiscutível as razões dessa mudança. Pode-se, porém, afirmar com relativa segurança terem sido fundamentais nesse processo duas ordens de fatores, a primeira ligada a uma história de vida transcorrida num período mais longo, responsável pela formação de sua personalidade e que ao mesmo tempo constituiu a sua memória; a segunda, a episódios mais recentes e de maior impacto.

Talvez não seja de todo inadequado fazer uma analogia dessa história da personagem com a história em sentido mais amplo. Nesta, grandes historiadores estabeleceram uma distinção entre a longa duração e a história dos eventos: as águas fundas e as águas superficiais, de Braudel, ou a força lenta e constante das águas e as forças vulcânicas e explosivas, de $\mathrm{Hinze}^{36}$. O crescimento de Carlota seria assim visto como a primeira das causas da mudança relacionadas à longa duração. A menina que havia partido para estudar na Corte fora gradativamente desaparecendo, e em seu lugar surgia uma moça, agora com dezesseis anos, é verdade que ainda muito jovem, mas que não tinha mais a ingenuidade da criança. Vivera muitos anos separada do pai e da mãe, longe da fazenda e de muito do que ali podia ser visto como inteiramente natural. Vivenciara ainda durante esse período, mesmo que na Corte distante, acontecimentos que atingiram duramente a família, como a morte da irmã e o início dos conflitos entre o

\footnotetext{
36 "E assim como Braudel recorre à analogia das águas fundas e águas de superfície, para mostrar a diferença entre uma história vagarosamente ritmada, onde cabem as estruturas e a longa duração, e outra feita de acontecimentos instantâneos, imprevistos, vibráteis - a história événementielle em suma -, Hintze vai procurar seus termos de comparação na geologia antiga, com as teorias dos netunistas e vulcanistas. Aqui, escreve, 'opera a força lenta e constante das águas, a produzir as estratificações sedimentares; ali agem os efeitos súbitos, explosivos, das forças vulcânicas, com suas formações eruptivas e cristalinas' " (Sérgio Buarque de Holanda, Livro dos prefácios, p. 212)
} 
pai e a mãe, de que ela devia de algum modo desconfiar ou que chegava pelo menos a intuir. Com o retorno à casa paterna, esses acontecimentos começam a se precipitar, e não há aqui evidentemente como fazer uma separação muito clara entre aquelas duas ordens. Depara então com a ausência da mãe e acompanha depois a partida do pai, não sem antes ouvir dele o comunicado a respeito de um casamento que não escolhera e que não poderia recusar. Tudo isso trazia o sofrimento que ela provavelmente experimentava pela primeira vez, pelo menos nessa intensidade, o que poderia ser também uma abertura para a visão efetiva do sofrimento alheio. Ao lado disso, ouvia alusões ao escravo Florêncio e ao seu assassinato, e com elas alguma referência à mãe. A ausência desta e do pai fazia com que o seu convívio com Libânia e Joviana fosse muito maior do que se estivessem presentes, e as conversas com uma e outra muito mais constantes e prolongadas, permitindo-lhe um conhecimento mais amplo da vida das escravas do que aquele que tivera até então. Começamos a entrar mais propriamente no campo das forças vulcânicas e explosivas quando tratamos da cena vista por Carlota em que o noivo, sem se dar conta de sua presença, põe-se a chicotear impiedosamente o trintanário, que não esboça qualquer reação. E nos encontramos em definitivo nesse campo quando vemos Carlota visitar a sala em que os escravos eram castigados. Pouco tempo antes disso, seus sentidos pareciam tornar-se num crescendo cada vez mais sensíveis, desde a visita à propriedade da Condessa, a fazenda do Paraíso, onde se sentira indisposta, passando pelo episódio dramático do retorno com Dona Virgínia, em que a vitória disparara pela estrada sem o cocheiro, e da chegada ao Grotão tomadas pelo pavor, e finalmente pela noite insone em que vagara pelo jardim, dormira um pouco e acordara de madrugada sem conseguir mais dormir. Esse estado de indisposição, de insônia, de quase convalescença parece ter sido o que propiciou a expansão dos sentidos que passam a captar tudo à sua volta em todos os detalhes ao tempo em que proporciona uma compreensão imediata do que durante muito tempo não pudera ser compreendido. Assim, antes de se dirigir ao quadrado naquela ocasião, Carlota passa pela capela e ajoelha-se diante da imagem do Cristo crucificado. Havia próximo à imagem

pequena lamparina de globo de cristal vermelho e sua luz dançava, quase esgotada a provisão de azeite, e os clarões de agonia faziam brilhar as gotas de sangue cravejadas de rubis que desciam pelo corpo do Crucificado. Os olhos de Carlota examinaram com espanto a expressão de dor profundamente humana daquele rosto, 
que parecia viver, nas contrações das angústias da morte próxima. Sentiu naquele drama silencioso entre sombras a acusação e o remorso que a fizeram levantar-se e caminhar, debaixo de sua recriminação envolvente e insustentável. (p. 474)

A mesma hipersensibilidade que permite a visão dos detalhes daquela imagem, que por sua vez imediatamente a levam a associar os sofrimentos do Cristo ao dos escravos ${ }^{37}$, expande a capacidade do tato a ponto de instantaneamente apreender, no "penoso esforço" com que corre "as pesadas corrediças" que fechavam as duas portas e com que tira a barra de ferro que as fixava, o "aviltamento" de um sistema que fazia com que os moradores da casa precisassem de tamanha proteção contra aqueles que trabalhavam para eles e que viviam bem ao lado, na senzala, separados deles apenas pelo quadrado.

Se todos esses eventos irruptivos, somados à história pessoal mais “vagarosamente ritmada", não bastassem, um último acontecimento faria cair o véu que até então encobrira a situação dos negros na fazenda paterna: a desajeitada recusa pelo noivo de Celestina do dinheiro que Carlota lhe oferece como dote, na intenção de dar alguma proteção e amparo à família que se estava formando, porque "ele tem sangue". Sem conseguir responder qualquer coisa para "explicar e justificar tudo o que se erguia junto dela", Carlota disse apenas "adeus", enquanto ele, por sua vez, retirava-se devagar e arrependido por tê-la magoado. Enquanto isso o dinheiro cai e se espalha pelo chão, e é Joviana quem se põe a recolhê-lo, enquanto Carlota tenta impedi-la, dizendo que ela não deve tocar nele. Como um duplo exemplo da quase absoluta incompreensão entre os seres humanos, por um lado, e da introjeção pelo escravo do menosprezo que os homens livres lhe votam, por outro, a velha ama interpreta a censura da Sinhazinha como uma advertência de que uma soma tão grande de dinheiro como aquela não podia ser tocada por alguém tão sem valor como ela, e então procura rapidamente colocar as notas sobre a mesa, bem longe de si.

Todos esses fatos recentes, ocorridos num período tão curto, parecem ter sido potenciados por essa concentração mesma e por terem sido vivenciados por uma jovem

\footnotetext{
${ }^{37}$ Confesso não ter conferido de início grande importância ao momento em que Carlota se detém na capela antes de se dirigir à sala dos castigos e só ter prestado maior atenção a ela com a leitura do já citado ensaio sobre o romance escrito por Maria Aparecida Santilli. Trata-se de uma leitura verdadeiramente enriquecedora, contendo algumas observações muito argutas sobre A menina morta. Contudo, absolutamente não consigo ver uma "escalada mística" de Carlota ou a "alvorada da sua epifania" no percurso que vai de seu quarto à sala dos suplícios, escalada que seria ainda formalizada na passagem pela capela. Inegável a associação, que Maria Aparecida Santilli percebe muito bem, entre a cruz e o tronco, mas para mim insuficiente para que se reduza a transformação de Carlota a uma "conversão mística". Contudo, sendo uma leitura tão bem fundamentada, é possível que as divergências sejam apenas fruto das diversas possibilidades de leitura que uma obra tão complexa permite.
} 
que já se tinha tornado mais sensível quando da mudança relativamente brusca e inesperada que experimentou ao ter de deixar a Corte e o colégio para retornar à fazenda do pai, o que acabou por proporcionar uma transformação radical, expressa na imagem da morte da menina que havia dentro dela, como já foi visto, processo que só se completa inteiramente depois da visita à sala de suplícios, completude que é explicitada por meio da utilização do mais-que-perfeito, tornada ainda mais enfática no caso do verbo desaparecer pelo advérbio que intensifica o seu sentido: "Envelhecera, e não estava mais ali a jovem que chegara do Colégio. Qualquer coisa de acerbo em sua boca, a sombra que agora velava os seus olhos, faziam dela outra mulher e a menina desaparecera irremediavelmente." (p. 479, grifos meus) E foi essa mudança que a levou à decisão de libertar os negros da fazenda, o que pôde ser feito depois de oficialmente transferida a ela toda a propriedade. Após a formalização dessa decisão, tenha ou não relação direta com ela, tudo o mais se precipita: a notícia da morte do Comendador; o rompimento do acordo para o casamento com João Batista, sem qualquer comunicado formal ou informal, mas sugerido pela partida da Condessa e do filho para a Corte; a debandada gradual das agregadas, que também partem sem se despedir de Carlota; o retorno da mãe, dona Mariana, enlouquecida.

Como o que se narra no romance não é a continuidade, mas a interrupção, não é a permanência, mas a ruptura, o processo que levará à derrocada do sistema escravista e à dissolução da família patriarcal, penso ser possível a proposição de uma leitura alegórica do curso dos acontecimentos em A menina morta remetendo-o à libertação dos escravos no Brasil. Há algumas coincidências: quem concede a liberdade aos escravos é uma mulher, fazendo-o por meio de sua assinatura num documento lavrado pelo tabelião local, e ocorrendo depois a comunicação do ato diretamente aos próprios escravos, interrompida no romance apenas pelo mal-estar sentido por Carlota; nada é previsto quanto ao futuro dos escravos, que ficam durante vários dias sem saber muito bem o que aquele episódio representava para eles e qual seria então o seu destino; a propriedade, não tendo se preparado para uma mudança como essa, entra em crise e termina em ruínas. A despeito dessas possíveis analogias e do que no romance possa ser visto como alegórico, o que procurei até aqui mostrar é que a grande força do narrado reside na particularidade da situação criada, que encadeia uma série de fatos de grande alcance - a morte da menina, os desentendimentos entre marido e mulher e o retorno da filha mais velha, dentre outros - e na singularidade da maior parte dos personagens 
envolvidos nesse terrível drama. Ao seu final, vemos Carlota encostada à parede onde se encontrava o quadro da menina morta, a conversar consigo mesma:

- Eu é que sou a verdadeira menina morta... eu é que sou essa que pesa agora dentro de mim com sua inocência perante Deus... Aquela que morreu e se afastou, arrancando do meu ser o seu sangue para desaparecer na noite, não sei mais quem é... e a mim foi dada a liberdade, com a sua angústia, que será a minha força! (p. 541)

Admito ter muitas dúvidas sobre essa fala, mas não há como fugir de sua discussão. Procuro interpretá-la de modo a confirmar o venho dizendo sobre a menina morta que é Carlota - na verdade, é bem o sentido literal dessa sua última fala. A menina que se foi levou consigo o que havia de seu sangue em Carlota, isto é, a menina que ela - Carlota - também era. Dentro dela, ficou apenas a menina morta. A sua "inocência perante Deus" parece-me uma inversão que não sei se seria aceitável para um pensamento católico mais ortodoxo. A despeito do pecado original e da necessidade do batismo, é comum atribuir-se a inocência às crianças. Cristo já dissera: "Vinde a mim as criancinhas." Mas no romance é somente depois de morta a criança, ou seja, depois que Carlota toma consciência dos horrores da escravidão e liberta os escravos, que ela se torna inocente perante Deus. Seria talvez o caso de pensarmos em dois sentidos para a palavra inocência: ingenuidade e ausência de culpa. Ao perder a inocência (ingenuidade), que fazia com que ela não questionasse e nem visse como problemática a condição dos negros, ela ganha, ao libertá-los, outra inocência (ausência de culpa). A opção pela liberdade, sem qualquer restrição, que ela diz the foi dada, penso ter sido conquistada ao preço da ruína do Grotão e do esfacelamento da família até então rica e poderosa, o que é ainda um preço muito menor do aquele pago pela mãe. É certo que ela não foi inteiramente responsável por esses acontecimentos, e talvez aí se possa compreender o sentido de que a ela "foi dada a liberdade": tudo o que ocorreu não foi ativado por ela, teve início ao contrário antes mesmo de seu retorno à propriedade paterna, com o que quer que tenha se dado entre o Comendador e Mariana, e com a morte da irmã, e talvez muito antes disso. Finalmente, além do preço que se paga pela liberdade, há a angústia que ela traz. $\mathrm{O}$ viver preso às constrições sociais, aos papéis a serem representados, a um mundo cruel e desumano, mas relativamente estável, é menos angustiante que o viver em liberdade. A angústia surge sobretudo 
diante do imprevisto, do inesperado, do desconhecido. Mas há sempre a positividade desse sentimento: a angústia é o que nos prepara para o encontro com aquilo que não podemos prever, com o que não esperamos, com o que não conhecemos. Por isso Carlota afirma que será ela a sua força diante dessa vida que não pode mais contar com as certezas da sociedade patriarcal e escravocrata.

Contudo, se a existência dessas certezas dentro dessa sociedade pode fazer com que a angústia seja, se não inteiramente evitada, ao menos um pouco mitigada, a mera crença que nelas se deposita parece insuficiente para manter inalterado aquilo que se crê absolutamente estável. Como foi dito, as tensões entre os dois mundos que na verdade estavam na origem daquele sistema acabariam por levá-lo à derrocada, sem contar, como também já se fez menção, as tensões internas a cada um deles, como a violência que, uma vez desencadeada, entra num processo irreversível de geração de mais e mais violência até voltar-se contra aquele mesmo que a havia desencadeado. Cabe notar aqui que ela talvez nem tenha necessariamente tido início naquela violência que se abatia sobre os negros, mas antes mesmo de sua chegada, na apropriação de terras que com muita freqüência se dava mediante a utilização da violência mais extrema ${ }^{38}$, processo que certamente teve continuidade ou se tornou ainda mais comum quando se recorreu ao tráfico de escravos para suprir a mão-de-obra que permitiria a produção agrícola em larga escala. Não há nenhuma referência direta a essas questões no romance, mas creio que a região em que Cornélio Penna localiza o Grotão e suas dimensões colossais tornam pertinentes essas reflexões. Por fim, a sua ruína, particularizada na história de Carlota, da menina morta, de Dona Mariana e do Comendador, remete às crises de toda a sociedade patriarcal e escravocrata no final do século XIX, sobretudo aquela do Vale do Paraíba, a principal delas ocorrida em 1870, segundo Maria Sylvia de Carvalho Franco, antes portanto da própria abolição da escravatura:

Também condições mais amplas perturbaram o ajustamento entre a produção brasileira de café e os mercados exteriores, na segunda metade do século. Esse período foi marcado por crises econômicas gerais e a depressão alcançou inevitavelmente aquele gênero. Nos fins da década de 1870, diante da crise e em face das abundantes colheitas esperadas, antevia-se o rebaixamento de preços, mas supunha-se, também, que isto fosse compensado pelo movimento correlato de

\footnotetext{
38 "A base dos grupos privilegiados, no Brasil, foi a apropriação de terras. Como no resto do país, na região aqui estudada elas foram obtidas, em grande parte, por meio da violência, da fraude, dos favores." (Maria Sylvia de Carvalho Franco, op. cit., p. 143.)
} 
aumento das exportações. Esta esperança foi, afinal, frustrada: "os preços nos mercados estrangeiros não só declinaram proporcionalmente, mas em presença da redução do consumo, retrocederam ainda mais, a tal ponto que a colheita abundante de 1878 dera resultado inferior as valores produzidos por colheitas anteriores menos abundantes", 39

Vemos assim que nesse caso pesaram menos as contradições internas do que as aludidas tensões entre o interno e o externo, que se manifestaram em problemas econômicos relativos aos preços internacionais do café. A literatura, porém, não tem por que priorizar esses fatores. E Cornélio Penna, escritor considerado intimista, sem absolutamente deixá-los de lado, como vimos em inúmeros exemplos, das descrições das plantações de café aos contatos do Comendador com o comissário, certamente enfatizou em A menina morta as questões mais próximas do homem e das relações humanas.

\section{O inferno é aqui: outras imagens dantescas}

Depois da experiência com os três primeiros romances, a segurança de Cornélio Penna ao lidar com a palavra escrita me parece inquestionável. Sem querer deduzir diretamente daí um juízo de valor relativo à qualidade literária, é preciso reconhecer a grande complexidade da trama e do espectro social do mundo criado pelo escritor em $A$ menina morta. Não deixando de colocar em destaque a psicologia das personagens, o que sempre caracterizou a sua literatura, Cornélio conseguiu dramatizar de maneira impressionante toda uma estrutura social que girava em torno daquela imensa propriedade, com a figura do proprietário, da mulher e dos filhos, dos agregados, da governante, do administrador, dos feitores, das amas-de-leite, do pajem, das mucamas de dentro, dos escravos de ofício e dos escravos do eito. E em relação a quase todos eles - com exceção talvez desses últimos - ele consegue obter uma profundidade que nos dá uma figuração reveladora em que alguns traços particulares fazem com que eles transcendam completamente o simples tipo. Como não imaginar em toda a sua vivacidade uma personagem como Sinhá Rola ou Dona Virgínia, Dona Inacinha ou a senhora Luísa, Libânia ou Bruno, Joviana ou Dadade, Carlota ou Celestina? É verdade que todos eles se apresentam quase que invariavelmente sem sombra de mistério,

\footnotetext{
${ }^{39}$ Id., ibid., p. 189-90.
} 
enquanto Mariana e o Comendador são personagens misteriosos e muitas vezes incompreensíveis, assim como os problemas em que estão envolvidos não são nunca aclarados. Uma vez mais - como tem sido uma constante - não tenho como dar uma resposta precisa a essa questão. Não teria talvez nem mesmo como defender Cornélio Penna de maneira insofismável da acusação de que se trata de um defeito literário de sua obra. Contudo, a suposição de ter havido algo entre Mariana e Florêncio parece tornar esse descompasso um pouco mais compreensível; ao não esclarecer de todo o mistério nem mesmo ao leitor, o que o escritor faz é chamá-lo a participar da história como se fosse mais um personagem, como foi dito, mais um agregado naquela fazenda em que havia tantos outros. Por outro lado, o modo como o escritor se detém muito mais na história desses personagens "secundários", como os agregados e os escravos, do que na vida do proprietário e de sua mulher, o que acaba por lançar mais luz naquela do que nesta, pode estar ligado ao seu maior interesse por eles do que pelos proprietários e ao propósito de dar-lhes um espaço na literatura que em grande medida lhes fora recusado no passado. Nesse sentido, Cornélio seria indiscutivelmente um escritor afinado com a modernidade e o modernismo.

Isso, entretanto, parece ainda insuficiente quando se trata de abordar o mistério na obra corneliana. Novamente, não há como fugir da questão colocada por Mário de Andrade sobre a gratuidade de alguns elementos misteriosos na primeira obra publicada pelo escritor. Neste último romance, o mistério não se restringe inteiramente às desavenças entre o Comendador e Mariana, mas aí como em tudo mais ele se liga de modo inextricável à escravização do negro e à violência do regime escravocrata:

Apesar do silêncio e da paz profunda que reinava no terreiro calçado de grandes lajes branquicentas, apesar da noite espessa que por ele se estendia, vultos tão negros quanto ela movimentaram-se sutilmente e espreitaram escondidos pelas grandes colunas de madeira feitas de tronco de árvores enormes desbastadas pela enxó dos carpinteiros cativos e que formavam a varanda do lado da senzala das mucamas. Parecia soturno bailado muito leve, em que as aves noturnas tomassem parte, ou seus protagonistas estivessem fantasiados de veludo preto, com sandálias de lã e fugissem de um lado para outro em corridas ágeis e silenciosas. Muito de longe, vindo da mata próxima, a subir o espigão perdido da Serra do Mar que formava o fundo do altiplano onde estava a fazenda, veio então, trazido pelas lufadas de vento morno do início da noite, o bater surdo de tambores, talvez de algum quilombo, onde os negros sentissem necessidade de desafiar os capitães-do- 
mato, indicando assim a sua presença nos longínquos grotões. Imediatamente todo movimento cessou e o negrume das trevas fez-se unido, imóvel, como se tudo estivesse à escuta de algum sinal indecifrável para os brancos, transmitido assim por aquelas batidas abafadas. (p. 65)

As referências muito diretas ao espigão da Serra do Mar, à senzala das mucamas, ao quilombo, aos capitães-do-mato trazem os elementos que radicam a descrição na realidade mais palpável, mas algumas das imagens criadas pelo escritor como que dissolvem essa realidade, tornando-a fantasmagórica e sombria, ao mesmo tempo em que ela surge: a "noite espessa", os "vultos tão negros" como a noite, o "soturno bailado", "as aves noturnas", os "protagonistas fantasiados de veludo preto, com sandálias de lã", o "bater surdo de tambores" e assim por diante. Não parece casual aqui na construção dessas imagens a utilização de palavras que tem a vogal $u$ quase sempre numa sílaba tônica. Essa assonância vem somar a sonoridade fechada do $u$ que se repete ao clima lúgubre e espectral da cena descrita. Trata-se, porém, de um movimento reversível, isto é, esses espectros e fantasmas têm lugar numa realidade muito concreta. Os negros fugidos, reunidos em quilombos, escondidos durante o dia, quando seriam presa fácil para os capitães-do-mato, saíam à noite, pondo-se a dançar e a tocar surdamente seus tambores, o que era ao mesmo tempo a prática de seus rituais ancestrais, ainda que com certo cuidado para não serem localizados, e o modo por que se comunicavam, em sinais indecifráveis para os brancos, com aqueles que se encontravam cativos e que também saíam à noite, incógnitos, para o terreiro.

Outras inúmeras imagens que surgem no livro aludem ao que se passa entre os negros, fugidos ou cativos, bem como a acontecimentos violentos, envolvendo mutilação e morte, ao mesmo tempo em que participam da narração do desenrolar de tarefas muitas vezes corriqueiras da fazenda, descritas com uma riqueza de detalhes e uma vivacidade impressionantes. No capítulo 20, por exemplo, narram-se as atividades ligadas ao preparo do azeite para as lâmpadas da casa: "grande tacho de cobre tinha sido já posto sobre a trempe, e por baixo dele fora feita pequena fogueira destinada a entretêlo em fervura, abrigada por pedras soltas, tisnadas de carvão.” Até aqui, vemos descritos os detalhes do processo, mas um pouco mais à frente pode-se ler: "Grandes bolhas se abriam na superfície da água, e o ruído da fervura enchia toda a enorme sala com o seu murmúrio, igual à conversa misteriosa de muitos negros lá na senzala quando tramavam alguma coisa má.” Ao qualificar o ruído da fervura de murmúrio, o escritor como que já 
prepara o terreno para a comparação que virá a seguir, em que alude à conversa misteriosa dos negros na senzala, analogia tornada possível pela semelhança entre os dois ruídos. Mas essa transformação de algo aparentemente banal em elemento terrificante já começara a se dar antes disso, na história da antiga governante que pretendera mostrar que sabia fazer o trabalho das mucamas e viera para a cozinha mexer no óleo de mamona fervente. Sem a experiência das escravas, "dera violenta volta com a colher", fazendo saltar gotas do óleo e "alguns desses pingos foram em cheio em seu olho direito e a tinham cegado". (p. 98) Essa história era sempre lembrada e contada quando alguém resolvia repetir o gesto da governante na ausência de Maria Crioula. Não devia ter diferente motivação as torturas a que os escravos eram submetidos, muitas vezes deixando em seus corpos marcas e mutilações visíveis e irremovíveis: lembrá-los de que não deviam repetir gestos de insubmissão ou tentativas de fuga. Mas, como quem revolvia o óleo fervente, e que era quem sabia como fazê-lo de modo adequado, era uma escrava, não há como não pensar no reverso da medalha: a violência sempre podia se voltar contra os senhores.

No capítulo 37, é a vez das goiabas serem levadas ao fogo para o preparo do “doce que seria provado com delícia [por Carlota], quando chegasse”. E aqui as alusões aos escravos parecem mais indiretas, mas não menos reveladoras: “[D.Inacinha] Já encontrou as goiabas descascadas com facas de bambu, postas em grandes alguidares de barro e tudo preparado para recebê-las, muito vermelhas, como em carne viva, e pareciam sangrar quando passadas na peneira fina." (p. 183) Como no preparo do óleo, torna-se inevitável a lembrança da menina, que se acercava com curiosidade dos tachos, e do susto que dava em todos no receio de que algo pudesse acontecer a ela. E se lá era mencionado que ela o fazia "para compreender a conversa dos diabinhos escondidos embaixo daquelas águas revoltas", fala-se aqui do "evidente perigo, na proximidade [da Sinhazinha] daqueles diabólicos tachos em ebulição".

Pouco antes, no capítulo 34, as senhoras dirigem-se ao terreiro, onde Joana Tintureira preparava as tintas para tingir as vestimentas que seriam feitas para os escravos:

Em três grandes tachos de cobre dispostos pela ordem de tamanho, fervia um líquido que continha pedaços de madeira, pedras e outros ingredientes. No primeiro tomara já certa cor azul muito escura e a espuma amarelada que se erguia sobre ele formava contraste; lembrava pequeno mar tempestuoso, a bater de 
encontro aos rochedos em ondas desordenadas. No segundo a cocção começava apenas a tomar sombria tonalidade avermelhada, como de sangue seco que se derretesse, e a do último era inteiramente negra. (p. 171)

Uma vez mais, temos a descrição - se descontarmos a perícia com que o escritor em poucas linhas nos dá uma imagem de uma plasticidade tal que torna impossível não a mentalizarmos de imediato, em suas formas, texturas e cores - até mesmo banal de uma atividade corriqueira. No entanto, cada uma das imagens parece comportar um segundo sentido. Como no romance é quase um leitmotiv a comparação entre a casa e um navio $^{40}$, o mar agitado e as ondas desordenadas, que parecem surgir diante da visão do tacho em que é preparada a cor azul, acabam associados à tempestade que se abatia sobre a casa e iria levá-la à ruína. Mais significativa talvez é a comparação do vermelho com o "sangue seco que se derretesse". E, finalmente, a cor preta - inteiramente desacompanhada no parágrafo de imagens e comparações - é objeto do diálogo que vem a seguir entre as agregadas e a negra, que "devia ser grande feiticeira". Esta começa a explicar o conteúdo de cada um dos tachos e, ao chegar ao último, diz ser de braúna. Depois de algumas perguntas dirigidas a ela, afirma ter pensado que seria preciso muita braúna para o luto, mas isso parecia no mínimo estranho, pois as mulheres tinham vestidos pretos suficientes e os escravos não usavam luto. Joana mesmo não sabe dizer porque tinha feito "aquela tachada de tinta negra que ela mesma ignorava qual o fim a ser destinada". E, ao final da conversa, não há como as mulheres não pensarem aquilo que Sinhá Rola termina por verbalizar: "Parece-me triste presságio esse $[\ldots]$.... isso até parece bruxaria!"

Todos esses presságios, essas menções a bruxaria, ao diabo e ao diabólico, assim como aquelas que foram feitas ao bode preto, embora possam ser vistos como índices alusivos à ruína do Grotão cada vez mais próxima, também caracterizam a situação da fazenda escravocrata antes de sua completa derrocada. Aliados às referências recorrentes ao estranhamento, ao automatismo, à mascarada, ao disfarce, à representação, à "comédia triste", à "inútil e cruel comédia" ou ainda à "insuportável comédia"41, dão notícia de um mundo verdadeiramente infernal não apenas para os escravos, cujos suplícios não diferiam muito daqueles presentes no imaginário católico ou cristão, mas para todos os habitantes da fazenda, personagens daquela comédia

\footnotetext{
40 "Lá fora o largo silêncio vinha até as janelas e parecia envolver toda a casa como um navio submergido por altas ondas negras sem espumas, sem a luz das estrelas, tapadas por nuvens opacas e lentas." (p. 141)

${ }^{41}$ Wander Melo Miranda utilizou a expressão como título de seu estudo sobre A menina morta.
} 
dantesca, em que as ações e os sentimentos mais comuns eram o fingimento, a dissimulação, a mentira, a perfídia, a adulação, a maledicência, a inveja, a disputa, o orgulho, a vaidade, o medo. Nesse contexto, todos são levados a uma situação de absoluto desamparo, palavra que é, com outras de mesmo radical, das mais recorrentes no romance e que pode ser compreendida a partir de seu primeiro sentido: ausência de escora, esteio, arrimo. Num lugar em que não se tem nunca certeza sobre o verdadeiro sentido das palavras ou das ações do outro, não há nenhum lugar seguro onde se possa encontrar apoio, nenhum chão mais sólido onde firmar os pés. Qualquer semelhança com o mundo em que o escritor viveu e com o nosso mundo não será, porém, mera coincidência. Não é este o momento para aprofundar essa questão, mas cabe ao menos adiantar que o que ele dramatiza em A menina morta, como já o fizera nas obras anteriores, é também o desamparo humano em sentido amplo, a dor de estar no mundo, a condição humana por excelência ${ }^{42}$.

\section{Quem sabe lê / pega no papé ou A loucura vem tomar parte no baile}

No tratamento daqueles presságios e pressentimentos misturam-se o catolicismo dos brancos e as crenças e a cultura dos negros. A mistura já é tão grande que algo que indique uma crença africana na origem pode ser expresso por um branco, e um negro pode muito bem aludir a um dogma católico. Assim, Dadade teria advertido Celestina de que o demônio "costuma rondar o quadrado" (p. 460) e são as mucamas que riem nervosamente de Dona Frau por ela ter deixado na despensa a tina com a água em que tomara banho, pois quando isso acontecia o "cujo" aproveitava para ali se banhar. Devese reconhecer que o demônio ou o diabo que as escravas imaginam seria muito diferente do que aquele imaginado pelas mulheres livres. A imagem do demônio dos negros estava certamente muito marcada pela figura dos deuses cultuados desde os tempos mais remotos por seus ancestrais. Mas é inegável que alguma coisa do diabo cristão nela se infiltrou.

Um dos episódios mais impressionantes do romance e sintomático tanto dos contatos quanto da separação que se mantêm entre negros e brancos, entre uma cultura inteiramente oral e uma outra, marcada fundamente pela escrita é a festa dos negros cativos, autorizada pelo Comendador, em homenagem à celebração do contrato de

\footnotetext{
${ }^{42}$ V. cap. 4.
} 
casamento de Carlota com João Batista. De início, ressalta o contraste entre as iguarias e as bebidas que eram servidas na casa-grande, mesmo nos dias comuns, mas sobretudo em dias especiais como aquele, e o que é distribuído aos escravos em dia de festa: roscas, doce de laranja e queijo ralado (“dom especial do Senhor”), e aguardente:

O senhor Justino, logo ao distinguir a senhora assomada à janela, veio até perto e comunicou-lhe que tudo estava prestes, só faltava o sinal. Dona Virgínia voltou para junto do primo e disse-lhe ao ouvido que estavam à sua espera, e então ele se levantou e convidou a todos para o seguirem, e recomendou a Carlota que lhe desse o braço a fim de abrirem a marcha. Quando surgiram no alpendre foram soltados foguetes que cortaram o céu negro com riscos de ouro, até explodirem muito alto, provocando o eco repetido pelos morros ao longe, e os negros deram vivas agudos ao Senhor e logo depois, ainda mais forte e mais nutridos, outro viva à Sinhazinha chegada da corte. Logo em seguida rompeu atroadora a orquestra rudimentar de atabaques e de chaque-chaques, na execução de rápida zabumba. Saíram então da senzala e atravessaram o quadrado, entre alas, alguns negros de roupas reluzentes de enfeites de metal e três negras de coroa à cabeça que vieram até a escada do alpendre, onde fizeram longa e profunda mesura diante da jovem sorridente. Então teve início a dança e todos se confundiram no batuque e cantaram o ponto, sempre o mesmo, por muito tempo.

\section{Quem sabe lê}

Pega no papé.

Os senhores ficaram alguns momentos ainda no alpendre e procuravam distinguir na luz difusa dos candeeiros os vultos agitados e gesticulantes. De quando em vez deixavam entrever muito rápido caras onde o ricto era de volúpia e de dor, e nelas até o riso se tornava sinistro. A música sempre igual, martelante, sem cessar, sobre-humana, alucinava gradativamente os dançadores, e eles começavam já a uivar em vez de cantar, a ter convulsões em vez dos passos primitivos do batuque e os senhores sentiram ser já tempo de se retirarem, porque a loucura viera tomar parte no baile. (p. 314-5)

À nítida separação espacial entre os dois grupos - um dentro do alpendre, numa posição mais elevada; outro, embaixo, no terreiro, separado daquele pela escada que ao mesmo tempo fazia a ligação entre um e outro espaço - corresponde a divisão estrita, mas não inteiramente estanque, entre espectadores e participantes. Antes, contudo, da festa dos negros começar de fato, ocorre o show pirotécnico dos brancos, que tem 
obviamente um forte componente sonoro, mas que é feito especialmente para os olhos. Muito diversa é a música e a dança dos negros, em que o fundamental é o som, o ritmo dos atabaques e chaque-chaques, combinados com os gritos e o ponto cantado por todos. A rigor, a platéia é ali uma excrescência, o ritual não foi feito para ser visto, mas para ser vivido. Tanto é assim que os que estavam no alpendre se retiram ao perceber que "a loucura viera tomar parte no baile", isto é, quando os participantes começavam a ser tomados pelo êxtase. Então, não há escolha, permanecer ali significaria ser tomado do mesmo modo pela loucura, por isso se afastam. É por isso também que penso ser muito mais adequado denominar esse enlouquecido baile de "ritual" do que de "espetáculo". Este, sim, estabelece nitidamente uma diferença entre espectador e participante, e é assim feito para ser visto e pensando-se mesmo na platéia. Mas nesse caso, estamos já na esfera da cultura sedentária e marcada pela escrita, isto é, na cultura dos brancos. No caso dos negros, mesmo capturados, feito cativos e assim fixados em um determinado lugar, muito distante aliás de seu lugar de origem, os ritos que praticavam advinham de uma cultura, se não inteiramente nômade, de muito maior mobilidade, e sobretudo uma cultura oral. Nesse sentido, é muito significativo o ponto que os negros cantavam no início: Quem sabe lê / pega no papé. Sabe-se ser muito comum dentre aqueles que não conheciam a escrita a sua sacralização no momento em que dela tomavam conhecimento. Papéis com trechos escritos eram tidos muitas vezes como amuletos ou talismãs com poderes inauditos de sorte, cura ou prevenção de doenças ou invencibilidade contra os inimigos. Aqui, curiosamente, é a palavra cantada que faz referência à palavra escrita. Como, contudo, o ponto é muito breve e relativamente inócuo para quem não é um participante, não é possível saber ao certo o que a leitura significava para eles e qual o seu sentido dentro do ritual. Isso não significa que não possamos especular sobre isso. No interior do enredo, há de haver aí alguma relação com o tabelião que por diversas vezes vem até a fazenda. Aquele que lavra no papel as decisões tomadas, sejam ligadas a contratos de casamento, transmissões de herança, cartas de alforria ou mesmo a libertação de todos escravos, devia ser visto como detentor de um poder extraordinário. Aquele que surge sempre em momentos que os escravos pressentem como decisivos, que conjura deuses e demônios por meio do registro no livro enorme, para a proteção de uns e maldição de outros, só podia ser formidável e temível feiticeiro. Sabemos, no entanto, que praticamente tudo o que ele lavra no livro que carrega consigo não tem valor algum. A começar pelas cartas de alforria, que ou são guardadas até ficarem amareladas ou chegam mesmo a ser rasgadas 
por aqueles que continuam vivendo do mesmo modo como viviam antes de a terem recebido. Depois, o contrato de casamento de Carlota que não se realiza e que nem mesmo é desfeito oficialmente com registro no mesmo livro em que fora lavrado. Com a ruína do Grotão, a transferência da herança para Carlota também não parece ter tido grande efeito a não ser possibilitar a ela a libertação dos negros. Mas mesmo essa, também lavrada no livro de registros do tabelião, foi menos importante do que o comunicado direto aos escravos de que estavam livres e, principalmente, do que o afrouxamento de toda a estrutura repressiva diante das ordens de Carlota e da desordem que depois disso tomou conta do Grotão. A liberdade que advém disso tudo, ademais, assemelha-se antes a dispersão, debandada, confusão, que a uma mudança capaz de propiciar novas formas de vivência e convívio, mais humanas e dignas, para os excativos.

Não creio que isso seja tudo e nem mesmo talvez o mais importante nesse episódio. Quem sabe lê, pega no papé parece-me apontar inevitavelmente para a sua contrapartida: e quem não sabe ler? Quem não sabe ler se a-pega à sua cultura, a cultura oral, mais rica em muitos aspectos que a cultura letrada, por mais que essa tenha demorado tanto para reconhecê-lo e ainda por tão poucos dentre os que sabem ler. Apegar-se a essa cultura significa entregar-se à dança ritualística, ao ritmo dos atabaques, às convulsões, à loucura e ao êxtase. A música martelante leva ao transe e à alucinação, é sobre-humana porque permite o contato sagrado com o divino. A separação e a análise, o que há talvez de mais típico na cultura letrada, não existem aí. Tudo é comunhão. Por isso, misturam-se a dor e a volúpia, e para quem eventualmente esteja assistindo, sem ter sido tomado pelo deus da música e da dança, o riso dos que dançam pode mesmo parecer sinistro, demoníaco. Mas a dor e a volúpia se misturam e o riso parece sinistro também porque é aquele o momento em que podem expressar e dar vazão a todo o inimaginável sofrimento, a toda a dor insuportável, a toda a inenarrável angústia que tinha lugar naquela fazenda infernal. Não podiam ainda se esquecer que era também aquele um momento propício para tentar conquistar alguma simpatia dos senhores, o que talvez os levassem a fazer, pelo menos durante algum tempo, um pouco mais brando o cativeiro. E é por isso que Carlota, mal se retirara do alpendre de braço dado com o pai, percebe que o ponto fora mudado e pouco depois consegue divisar "a frase [que] invadiu sua mente de um só golpe": Moço rico / Pra casá / C’Arbernazi.

A festa possui assim vários sentidos. Do ponto de vista do proprietário é um dos meios utilizados para a manutenção do status quo, ao permitir a periódica manifestação 
dos sentimentos e emoções brutalmente reprimidos no cotidiano atroz do cativeiro, pois a inexistência de válvulas de escape como essa poderia fazer com que todo o represado transbordasse um dia numa violência desmedida voltada contra os senhores e todos os brancos que de algum modo a eles se ligavam. Nesse sentido, pode-se mesmo dizer que, mais do que permitida, a festa é prescrita aos escravos ${ }^{43}$. Contudo, trata-se sempre de um rito ambíguo e seu caráter transgressivo não se deixa dobrar inteiramente ao uso que a esfera do poder pretende fazer dela. Para os negros, então, ao mesmo tempo em que a vêem como um momento propício para tentarem obter alguma simpatia e compaixão dos brancos ferozes, a festa é preservação e permanência, todavia não num sentido estreito de fechamento a influências externas, que procurariam manter inteiramente imodificados os seus rituais, tal como eram no passado longínquo, na terra de seus ancestrais. Aliás, essa parece mais uma visão de fora, talvez bem-intencionada, mas que não compreende o caráter aberto dessas manifestações. O ponto cantado que faz menção à escrita indica essa abertura ao outro de sua cultura; e o fechamento e o receio de mistura parecem ao contrário do lado da cultura dos brancos, manifestos na retirada para o interior da casa-grande antes que fossem contaminados pelo ritual extremamente sedutor da senzala, irremissivelmente atraídos para o abismo, o sorvedouro, a voragem da loucura e da danação. ${ }^{44}$

\section{A menina morta: anjo e demônio}

Simone Rossinetti Rufinoni, em trabalho recente, uma abordagem fecunda do último romance corneliano, interpreta a menina morta como um símbolo que possibilita o apagamento dos sinais impressos pela violência do regime escravista, o que daria a ele

\footnotetext{
43 "Um festival é um excesso permitido, ou melhor, obrigatório, a ruptura solene de uma proibição." (Sigmund Freud, "Totem e tabu", p. 168.) "A festa não significa necessariamente (...) o levantamento maciço das proibições, mas, em dia ou tempo de festa, o que é vulgarmente proibido pode ser permitido, por vezes exigido." (Georges Bataille, O Erotismo; p. 59.)

${ }^{44}$ Todas essas reflexões sobre o episódio da festa dos negros são obviamente de minha responsabilidade, mas só puderam ser feitas em função de minha participação em um curso de pós-graduação ministrado pelo prof. Nicolau Sevcenko - em que pude acompanhar de perto seu pensamento instigante e fecundo sobre a cultura popular e empreender algumas leituras de obras fundamentais por ele indicadas, como as de Erik Havelock, Walter Ong, Richard Kieckhefer e Carlo Ginzburg - e de meu diálogo constante com Elena Pajaro Peres e Nelson Aprobato Filho, estabelecido já de relativamente longa data, antes mesmo do "Deviração", e mesmo de uma conversa muito recente sobre o tema em questão, de que me vali também para a utilização das noções de "preservação" e "permanência". Igualmente importante foi a leitura de Religion and the Decline of Magic, de Keith Thomas.
} 
um caráter de fetiche ${ }^{45}$ : "Ao assumir estatuto de ícone abstrato com conotação algo mística, reunindo desejos humanos desvinculados da luta social, procede à falsa anulação da tensão das relações sociais no interior da ordem patriarcal." ${ }^{46}$ Baseando-se em Walter Benjamin, estabelece a autora, contudo, uma distinção, que me parece produtiva, entre o símbolo presente no enunciado e a alegoria, na enunciação, de modo que seja possível notar na estrutura do romance a visão crítica do autor com relação à sacralização da menina como instrumento da dominação para abafar possíveis contestações e revoltas por parte dos dominados. Lançando mão do pensamento de René Girard, o que também fora feito por Wander Melo Miranda, Simone Rufinoni vê a menina como a vítima sacrificada para que a violência não se generalizasse e tomasse conta de tudo e de todos. A diferença entre as duas abordagens, contudo, é que para ela essa seria apenas uma das faces do mito da menina, enquanto a outra seria aquela propriamente histórica: a violência que se busca conter é "historicamente determinada, resultante das relações sociais", assim como o que o sacrifício busca é preservar a ordem do sistema escravocrata e não impedir, de modo genérico, o desencadeamento da violência inata a todos os homens. Como quer que seja, ainda na esteira de Girard, não sendo a violência estancada de todo, ela exige sempre novas vítimas, e Carlota será chamada para substituir a menina e, ao não fazê-lo, instaura a "crise sacrificial". Aqui, a historicização dessa crise leva a autora a associá-la à derrocada da grande propriedade fundada no trabalho escravo, por motivos encontráveis na história de sua decadência, dramatizados no nível do enredo também pelas ações de Carlota. ${ }^{47}$

Ainda que a interpretação do motivo da menina morta com base na teoria de Girard torne-se mais rica e esclarecedora quando considerada dentro de uma perspectiva histórica, parece-me que há algo mais a ser dito. Assim como a realidade, a obra de arte escapa às nossas tentativas de apreendê-la de todo por meio de teorias as mais fecundas e abrangentes, o que é por sinal o que permite e mesmo demanda a continuidade do trabalho crítico. Penso que o mais terrível do sistema escravista como mostrado no romance é que ele parece prescindir de vítimas sacrificiais como as descritas por Girard, isto é, aquelas que são escolhidas dentro do próprio grupo que se quer preservar. A menina tornada mito sagrado é apenas um dos elementos que mantêm a ordem do

\footnotetext{
${ }^{45}$ Luiz Costa Lima, na obra fundamental e por um bom tempo solitária, recentemente reeditada, já havia assim compreendido a figura da menina morta, "convertida em fetiche e mito, suspensa no tempo, com o papel de ocultar os conflitos reais". (O romance em Cornélio Penna, p. 192.)

${ }^{46}$ Favor e melancolia, p. 127.

${ }^{47} \mathrm{~V}$. sobretudo 3.5 - O romance entre a crise sacrificial e a crise do eu, id. ibid.
} 
Grotão. A própria violência voltada contra os escravos parece muito mais efetiva: os castigos físicos, as torturas, as mutilações e o assassínio, embora este somente seja utilizado em último caso, por razões pura e simplesmente de ordem econômica. E aqui, sim, caberia muito bem a palavra sacrifício, em mais de um sentido. Outros expedientes que buscam evitar contestações, revoltas e fugas são a vigilância constante pelos feitores; a mistura entre negros de diferentes etnias e que não falavam a mesma língua; a divisão dos próprios escravos em níveis hierárquicos, como as mucamas de dentro e os escravos do eito; a permissão para a realização esporádica de festas e ritos africanos; a concessão de prêmios de consolo em forma de comida e aguardente ou a distribuição de chapinhas para serem juntadas ao longo da vida e quem sabe um dia propiciarem a alforria; a união de dois escravos como marido e mulher, geralmente determinada pelos proprietários, o que enraizava na propriedade a família assim constituída e a vinculava mais estreitamente a seus donos; etc.

Quanto aos agregados, praticamente não representavam perigo, simplesmente em função da inexistência de outras opções de vida. Vimos como, diante dos pressentimentos de que se aproxima a ruína do Grotão, agregadas como Dona Inacinha e Sinhá Rola só conseguem pensar em outros proprietários que poderiam acolhê-las ou ajudá-las, e é o que finalmente acontece. Ademais, por pior que fosse a situação de dependência em meio às relações marcadas pelo favor, podiam sempre se sentir em muito melhor condição que os cativos, obrigados ao trabalho extenuante e degradante, sobre quem aliás podiam se desforrar das humilhações sofridas e de algum modo alimentar a ilusão de poder e distinção. Por fim, os proprietários, ainda que odiados, eram quase sempre parentes com quem, bem ou mal, tinham dívidas de gratidão e, diante do menor sinal de revolta por parte dos escravos, não teriam a menor dúvida sobre o lado em que deveriam ficar, ainda que movidos apenas pelo verdadeiro pavor que sentiam de uma possível rebelião sangrenta da escravaria, que muito certamente não faria qualquer diferença entre brancos proprietários e agregados.

A riqueza e a complexidade do motivo da menina morta, para mim, encontra-se exatamente em sua ambigüidade, no paradoxo expresso pela imagem de anjo ao mesmo tempo que demônio. À visão da menina como “um anjo entre escravos", leitura ingênua que assume a fala e os sentimentos dos personagens como a verdade da obra, não precisa ser contraposta uma outra que apenas enfoque sua face demoníaca. Para o bem e para o mal, ela não tivera tempo de colocar sobre o rosto infantil a máscara ou as máscaras que os adultos invariavelmente utilizavam, ainda quando no recesso dos 
quartos em que se fechavam para dormir. Desse modo, ela ainda podia tanto não fazer diferenças entre proprietários e agregados, entre um e outro agregado, ou entre um agregado e um escravo, como brincar de dar chicotadas no pajem do Comendador. Mais do que diabólico no sentido do mal, seu caráter demoníaco encontra-se na inversão de muitas de suas atitudes de criança. As chapinhas que distribuía às escravas para juntarem e um dia obterem com elas a alforria eram motivo para vinganças posteriores por parte dos feitores, e o dia em que eventualmente elas conseguissem obtê-la aconteceria o mesmo que com Libânia e Joviana, libertas de direito, mas não de fato. Além disso, como foi mencionado, a contrapartida de seus pequenos gestos de caridade é a violência de que os escravos são vítimas, o sorriso terno do feitor em resposta ao seu sorriso é o equivalente da mudança daquele sorriso em diabólica gargalhada ao vergastar o escravo e ao colocá-lo no tronco.

Carlota, contudo, prestou-se ao mesmo papel na infância. A sua exclamação "eu sou a menina morta" tem mais esse significado, e a confusão entre uma e outra encontra aí uma de suas possíveis explicações. Isso nos leva a crer que diferentes meninas, filhas dos proprietários, podiam atuar do mesmo modo, como imagem que minora o sofrimento de escravos e agregados ao tempo em que agrava a realidade de sua condição. É essa a descoberta de Carlota; é esse o motivo do verdadeiro ódio que toma conta dela em relação à menina, mas que no fundo é uma espécie de ódio retrospectivo em relação ao que ela mesma fora e ao que fizera quando criança, por isso muito mais forte.

Com a morte da menina e com a ausência de alguém que a substitua, é compreensível que no imaginário dos moradores do Grotão os gestos da criança ganhem uma dimensão ainda maior do que no tempo em que vivia. Retrospectivamente, aquelas pequenas ações caridosas e as diminutas alegrias que proporcionava, mesmo que tãosomente por sua presença pueril, se destacam e sobrepujam quaisquer outras lembranças, e avultam ainda mais em meio ao ambiente sombrio marcado pelo luto e pela violência que ele não interrompe um minuto sequer. Contudo, como costuma acontecer, à medida que o tempo passa as lembranças vão se apagando, a memória vai confundindo a menina morta e Carlota-menina ao tempo em que aumenta a necessidade de alguém que substitua a primeira. Mas Carlota não poderia fazê-lo, a não ser na aceitação dessa confusão entre a sua infância e a da outra. A menina que havia dentro dela morrera, o pai decidia o seu casamento e a Sinhazinha devia ser preparada para assumir o lugar de Sinhá-dona. O que impediu a realização desse projeto, como vimos, 
é que, da identificação com a irmã mais nova, o que todos desejavam e que de fato se dava, ela passa a se identificar cada vez mais com a mãe na mesma medida em que vai descobrindo que a propriedade paterna fundava-se na violência e no terror. E dona Mariana, ainda que não possa ser confirmada a hipótese da relação com o escravo e por menos que sua intimidade e seus pensamentos sejam revelados no romance, não parece compactuar com a exploração desumanizadora do negro ${ }^{48}$.

A menina pode ser vista como símbolo degradado como fetiche, que procura ocultar as tensões internas da grande propriedade fundada no trabalho escravo, mas é também uma das causas da ruína dessa mesma propriedade à medida que, com sua morte - como quer que ela tenha ocorrido -, é potencializado o seu caráter ambivalente e diabólico: tanto mais divide quanto mais parece apaziguar, tanto mais revolta quanto mais sugere calma e tranqüilidade, tanto mais desestabiliza quanto maior sensação de segurança traz, tanto mais destruidor quanto mais cândido e inocente se mostra. Contudo, para dizer uma vez mais, a complexidade desse motivo e da obra só será atendida caso se reconheça a verdade, ainda que relativa, do lado positivo de cada um desses pares de opostos. De algum modo, a menina representava de fato a paz, a tranqüilidade e a candura, o que não significa que ela - sobretudo com sua morte - não tenha contribuído para a divisão, a insegurança e a ruína. Dentre outros responsáveis, estariam, sem dúvida, Carlota e a mãe, com quem tudo começou: Dona Mariana, se estiver certa a leitura de sua relação com Florêncio, pela transgressão inconcebível do ato num regime patriarcal, mas também pela oposição ao Comendador e à escravização dos negros; Carlota, por não levar adiante o casamento arranjado pelo pai, por libertar os negros sem pensar no que seria feito deles nem em como substituir a mão-de-obra escrava e, finalmente, por não assumir de fato a administração da propriedade na falta do pater famílias.

Diante disso e da morte do Comendador, vão-se embora os agregados, dispersam-se os escravos, arruína-se a outrora imponente fazenda escravocrata. No Grotão, permanecem apenas três mulheres - Carlota, dona Mariana, enlouquecida, e Frau Luísa, por não ter para onde ir - e o velho Manuel Procópio.

Assim, se ainda houver alguma positividade num final tão melancólico, seria a sugestão de que algo novo possa brotar ali um dia, possibilidade que, remota que seja, só poderia ser pensada diante da destruição de toda aquela estrutura arcaica fundada na

\footnotetext{
48 "Mas a demanda que iniciara Mariana será continuada por sua filha e sucessora." (Luiz Costa Lima, $O$ romance em Cornélio Penna, p. 145.)
} 
violência e na desumanidade. E não sei se seria um exagero pensar que, sendo uma mulher a maior responsável pelo fim desse sistema patriarcal, e como que encarnando ainda duas outras figuras femininas, o escritor esteja sugerindo que essa vida nova - que seria o exato oposto da morte em vida do sistema escravocrata - somente poderia surgir a partir da mulher e do campo do feminino. Por enquanto, no seu tempo e no nosso, marcados por outras formas de dominação masculina ${ }^{49}$ (ainda quando exercidas por mulheres), tão ferozes e desumanas quanto aquela que o romance dramatiza, infelizmente, o advento dessa vida é ainda promessa ou utopia ${ }^{50}$.

Todavia, nada virá gratuitamente, mas apenas como conquista. É ainda Simoni Rufinoni quem afirma a inutilidade do gesto de Carlota para os escravos, que sequer o compreendem, e por isso apenas se dispersam sem rumo ou permanecem refugiados na senzala. Lampejos de uma possível liberdade podem ser encontrados antes nos negros fugidos que, nas cercanias da fazenda, reúnem-se à noite ainda feito sombras, não numa espera muda e passiva, mas na atividade possível para que possam um dia vir a se mostrar à luz do dia, livres, sem qualquer ameaça de retorno à servidão. Por isso, a despeito da presença mais constante dos agregados, A menina morta é um romance sobre o negro e a escravidão. Se os dependentes eram parte importante do regime servil, os negros vindos da África ou descendentes dos que de lá vieram capturados são o seu fundamento e os que mais sofreram a sua crueldade e o seu terror. Qualquer inversão nesses termos, a qualquer título, parece-me um equívoco.

É por esses motivos todos que o último romance é o mais contundente dos escritos por Cornélio Penna, o de maior impacto, o mais apavorante e assustador. O desconhecimento, o desamparo, o estranhamento, as divisões dos sujeitos, as máscaras, as ações maquinais, as ações e gestos dos homens como se fossem marionetes e títeres, os fantasmas e os espectros que perambulam pelas suas habitações, tudo se relaciona de

\footnotetext{
${ }^{49}$ Foi somente depois de ter escrito essas observações que fui ler um artigo que se encontra no acervo do escritor, publicado na Tribuna da Imprensa, em 21/10/55, em que Cornélio - perguntado sobre o "papel da mulher na sociedade e no lar" - afirma: "A mulher tem um papel muito importante na vida de hoje. A ela cabe o encargo de reconstruir, com doçura e suavidade, tudo o que os homens vêm destruindo através dos anos." A propósito dessa questão, Luis Bueno chega a falar em "literatura quase feminina", mas a observação que faz a seguir é mais importante que esse "quase rótulo": "Não é à toa que no epílogo de sua obra, ao final de A Menina Morta, é uma mulher, Carlota, que fará um gesto, suicida, é verdade, mas voluntário e positivo, para apagar o mal que se fez a mulheres e negros na fazenda que recebe de herança no Vale do Paraíba." (Uma história do romance de 30, p. 549.)

${ }^{50}$ Costa Lima opõe o caminho feminino da clareira ao caminho masculino da corte e ao espaço também masculino da casa-grande. (Id. ibid., p. 106.)
} 
algum modo com o monstruoso sistema escravista ${ }^{51}$. Instaurada a violência por aqueles que esperam dele se beneficiar, ela se espalha e prolifera, penetra em todos os cantos e recantos da grande fazenda, em todas as relações e no interior de todos os homens - e aqui o pensamento de Girard é de fato esclarecedor - até se voltarem contra aqueles mesmos que a instauraram, pois se a morte do Comendador e do filho tem como explicação a doença, a febre amarela, ela também é parte dos acontecimentos que se precipitaram desde a morte da menina, mas cuja origem recua para o tempo dos ancestrais da família Albernazi, caracterizados pelo poder, pelo orgulho e pela crueldade, que comparecem assombrados e feito assombrações nas histórias de Dadade. Uma vez mais em Cornélio, como vimos, o trágico retorna à cena. Como nas famílias de Édipo ou de Orestes, os filhos pagam pelos crimes dos pais e dos avós, como também não deixam de pagar pelos próprios crimes e de responder pela própria hybris.

51 “O efeito de mistério que dele [o romance] se desprende não se deve a intrusões aleatórias de seres embruxados, mas à própria realidade material e moral de uma fazenda às margens do Paraíba e às vésperas da Abolição." (Alfredo Bosi, História concisa da literatura brasileira, p. 471.) 


\section{FRATURAS NO OLHAR: REALIDADE E REPRESENTAÇÃO EM CORNÉLIO PENNA}

Orfeu, dividido, anda à procura dessa unidade áurea, que perdemos.

Mundo desintegrado, tua essência Paira talvez na luz, mas neutra aos olhos Desaprendidos de ver; ...

Carlos Drummond de Andrade 


\subsection{Fraturas no olhar: realidade e representação em Cornélio Penna}

Em Mímesis: desafio ao pensamento, Luiz Costa Lima dá continuidade à tarefa a que se lançou de re-pensar a representação, não no sentido de colocar novamente em pauta a concepção platônico-aristotélica da mímesis como chegou até nós, vista quase sempre como semelhança ${ }^{1}$, mas de considerá-la de um outro ponto de vista, que enfatize ao contrário a diferença e que dê conta da arte produzida por e para um sujeito fraturado, e que ainda se contraponha à abordagem conhecida como desconstrucionista, que recusa de todo e ao mesmo tempo as noções de representação e de sujeito. Não tenho como (e nem caberia num trabalho como este) entrar em detalhes sobre o modo como desenvolve a sua teoria, de maneira arguta e com notável erudição, mas interessa aqui particularmente a noção de sujeito fraturado. Esta, Luiz Costa Lima vai encontrá-la já no pensamento do Kant da Terceira crítica $^{2}$, passando depois por Schopenhauer, Nietzsche e Freud. E é sobretudo depois das descobertas freudianas sobre o inconsciente, mostrando entre outras coisas que "o ego não é mais senhor na própria casa",3 que me parece mesmo inconcebível a proposição de um "sujeito solar", uno e íntegro, o que não significa a rejeição automática da possibilidade de toda e qualquer representação, levada a cabo por Deleuze e outros pensadores, a partir de Nietzsche e com base no pensamento antes de Lacan que de Freud. O que propõe Costa Lima é que, mesmo diante das fraturas do homem moderno, ainda se pode falar em representação e em mímesis, não mais como imitatio, como cópia do real, como referida a um objeto artístico que mantém uma semelhança necessária com algum elemento concreto da realidade ou com a verdade ou o verdadeiro, antes uma mímesis da diferença, do que se põe em relação tensa com a realidade, do que antes se opõe ao real do que dele se aproxima, de todo modo sem nunca perder algum tipo de vínculo com ele. Não sendo

\footnotetext{
${ }^{1}$ Costa Lima esclarece que, se antes de Platão e Aristóteles o campo "pré-conceitual" da mímesis não condizia de modo estreito com a semelhança, mas levava em conta também a diferença, no próprio pensamento desses filósofos há momentos em que esta chega a preponderar sobre aquela. Käte Hamburguer afirma mesmo que, para Aristóteles, "mimesis é muito menos decisivo no sentido de imitação, matiz de significado de fato nele contido, do que no sentido fundamental de representação, de fazer." E em nota de rodapé menciona o livro de H. Koller, em que ele mostra que também Platão "entendia por mimese apenas representação, associando, p. ex., a palavra dessemelhante (anomoios) com mimeisthai ...". (A lógica da criação literária, p. 3.)

2 “... o sujeito da apercepção transcendental se põe no limiar da dicotomia entre entendimento e razão. Para que ele próprio não se converta em matéria transcendente, que, como sabemos, supõe em Kant uma resposta fenomenicamente inapropriada, precisa se manter nesse limiar, não dar um passo além de seu caráter lógico, formal. A unidade do sujeito kantiano implica, portanto, não só uma maior complexidade senão alternativas antagônicas. Ou seja, fraturas.” (p. 105)

3 "Uma dificuldade no caminho da psicanálise", Obras completas.
} 
calcada na realidade e sendo dirigida a um homem também fraturado, a obra de arte não só permite múltiplas interpretações como seu sentido é interminável, mas não indecidível, como querem os desconstrucionistas:

... o efeito da leitura implica por certo uma transferência, uma interminabilidade do sentido, não necessariamente uma indecidibilidade. Para que a distinção se faça válida, é preciso acrescentar que o ato de leitura crítica implica a recolha de sinais e marcas que, sem recuperar o real, como que implicitamente se afirma na concepção antiga da mímesis, o indiciam. O real assim não é nem o que se põe diante de mim e exige uma linguagem transparente, nem tampouco o que se embaralha em uma cadeia deslizante de significantes, i.e., de promessas de sentido, sempre autodestruídas. O real é isso e aquilo; algo que está aí e algo que se constrói. Por isso, a mímesis não é uma adequação - uma imitatio - mas um processo que, independente do real, contudo contrai, absorve, deforma as formas como o real historicamente aparece para o autor e o leitor. A representação-efeito, desdobrada pela leitura, leva em conta não só como se lê mas as fraturas que constituem aquele que lê. Dito mais precisamente: o sujeito fraturado e a classificação social da sociedade e do grupo a que pertence. ${ }^{4}$

Mas por que interessaria ao teórico por assim dizer salvar os conceitos de representação e de sujeito? Por uma dupla motivação, teórica ao mesmo tempo que política. É que por trás do banimento desses conceitos Luiz Costa Lima vê a afirmação do poder individual daqueles mesmos que o empreendem, que reclamam o direito não só de teorizar sobre uma arte em que representação e sujeito se encontram ausentes, como de instituí-la como padrão e modelo a que nenhum artista pode escapar, sob pena de ter desvalorizada e diminuída a sua obra. O sujeito expulso pela porta retorna pela janela, materializado na figura desses mesmos pensadores. E nem se pode dizer que o que volta é um sujeito fraturado, pois a posição que reivindicam - a de quem tem a autoridade e a competência para estabelecer a norma - só pode ser ocupada por um sujeito solar. ${ }^{5}$ Além disso, Costa Lima busca possíveis caminhos para a saída do

\footnotetext{
${ }^{4}$ Id. ibid., p. 398.

5 "Em nome da morte do sujeito, legitima-se o valor conferido pela assinatura de um certo sujeito - o filósofo ou o crítico de arte. O que vale dizer, a afirmação da dissolução do sujeito facilita a admissão dos juízos de um certo sujeito, o qual, certamente, para ser admitido, já deve trazer um certo halo de respeito. Normatividade facilitada, de um lado, pelo prestígio do lugar ou instituição de onde fala quem fala, de outro pela mudez do sujeito de que fala." (Id. ibid., p. 156) "A reconsideração pois que se procurou fazer das vicissitudes da história do par sujeito e representação no pensamento moderno visou a chamar a
} 
impasse em que há algum tempo se encontra a produção artística, colocada entre o que se acredita ser pura abstração, reconhecida e incensada pela crítica e, no geral, sem diálogo com o grande público ${ }^{6}$, e a arte ingenuamente mimética, de apelo popular e desprezada pelos críticos.

Sem entrar propriamente na questão política, registrando embora que Luiz Costa Lima parece ter boa dose de razão, acredito que o modo como procuro ver a literatura em geral e a obra de Cornélio Penna em particular aproxima-se bastante de sua posição, especialmente no que se refere às fraturas do sujeito e ao inevitável vínculo que toda obra tem com a realidade, mesmo que a ela se contraponha, ainda quando a rejeite.

Ao tratar especificamente da pintura, Merleau-Ponty, num belíssimo ensaio, parece em certo momento aproximar-se daqueles que Costa Lima critica, sem contudo coincidir de todo com eles:

A profundidade pictórica (e também a altura e a largura pintadas) vem, não se sabe de onde, colocar-se, germinar sobre o suporte. A visão do pintor não é mais o olhar posto sobre um fora, relação meramente "físico-óptica" com o mundo. O mundo não está mais diante dele por representação: é antes o pintor que nasce nas coisas como por concentração e vinda a si do visível, e o quadro finalmente só se relaciona com o que quer que seja entre as coisas empíricas sob a condição de ser primeiramente "autofigurativo"; ele só é espetáculo de alguma coisa sendo "espetáculo de nada", arrebentando a "pele das coisas", para mostrar como as coisas se fazem coisas e o mundo, mundo. ${ }^{7}$

As expressões destacadas pelo autor, sobretudo, parecem em acordo com a visão autotélica da arte, do objeto artístico que não remete a nada senão a si mesmo. Entretanto, pouco mais à frente, dirá:

A visão é o encontro, como numa encruzilhada, de todos os aspectos do Ser. (...) Nesse circuito não há nenhuma ruptura, impossível dizer que aqui termina a natureza e começa o homem ou a expressão. É portanto o Ser mudo que vem ele próprio manifestar seu sentido. Eis por que o dilema da figuração e da não-

atenção para os riscos do anti-representacionalismo; para a sua paradoxal manutenção do sujeito, em posição tal que facilita a normatividade do analista." (p. 157)

6 “... o divórcio entre arte e mundo, se bem que historicamente explicável, não é inevitável ou sequer desejável." (Id., ibid., p. 278)

7 "O olho e o espírito", p. 37. 
figuração está mal colocado: é ao mesmo tempo verdadeiro e sem contradição que nenhuma uva jamais foi o que é na pintura mais figurativa, e que nenhuma pintura, mesmo abstrata, pode eludir o Ser, que a uva do Caravaggio é a uva mesma. ${ }^{8}$

Realidade e pintura (e não poderíamos dizer realidade e obra de arte?) mantêm entre si relações extremamente complexas, de intercâmbio e mútua influência, uma repercutindo na outra, de modo tal que Claude Lefort pôde dizer de Merleau-Ponty que ele escrevera "O olho e o espírito" no campo, não muito distante de Aix, lugar em que podia usufruir "diariamente a paisagem que conserva para sempre a marca do olho de Cézanne". 9 Talvez seja menos o acaso e mais a importância fulcral de sua obra para a modernidade o que faz com que Costa Lima recorra ao mesmo pintor para tecer considerações muito semelhantes:

A maçã de Cézanne não é idêntica à maçã que comemos. Mas, depois de sabermos o sol e a maçã da pintura, já não os vemos, no mundo que nos envolve, da mesma maneira que antes. Rua de mão dupla, a mímesis não só tira do mundo mas lhe entrega algo que ele não tinha. Que substancialmente continuará não tendo mas que, nem por isso, deixará de incorporar. Ao fazer ver doutra maneira, ela reconhece a existência do que dela não depende; ao mesmo tempo, provoca o conhecimento do que, sem ela, não seria possível de se obter. ${ }^{10}$

E me permito uma última recorrência ao filósofo francês e a suas reflexões sobre a pintura, novamente com uma menção a Cézanne:

Já que as coisas e meu corpo são feitos do mesmo estofo, cumpre que sua visão se produza de alguma maneira nelas, ou ainda que a visibilidade manifesta delas se acompanhe nele de uma visibilidade secreta: "a natureza está no interior", diz Cézanne. Qualidade, luz, cor, profundidade, que estão a uma certa distância de nós, só estão aí porque despertam um eco em nosso corpo, porque este as acolhe. Esse equivalente interno, essa fórmula carnal de sua presença que as coisas suscitam em mim, por que não suscitariam por sua vez um traçado, visível ainda, onde qualquer outro olhar reencontrará os motivos que sustentam sua inspeção do mundo? Então

\footnotetext{
${ }^{8}$ Id., ibid., p. 44, grifos meus.

${ }^{9}$ Id., ibid., "Prefácio", p. 9.

${ }^{10}$ Mímesis: desafio ao pensamento, p. 327-8.
} 
surge um visível em segunda potência, essência carnal ou ícone do primeiro. Não se trata de um duplo enfraquecido, de um trompe l'oeil, de outra coisa. ${ }^{11}$

O eco que o visível desperta em nós - bela imagem que mistura sinestesicamente visão e audição - repercute no artista, que - tocado - compõe a obra que irá ressoar naquele que a contempla.

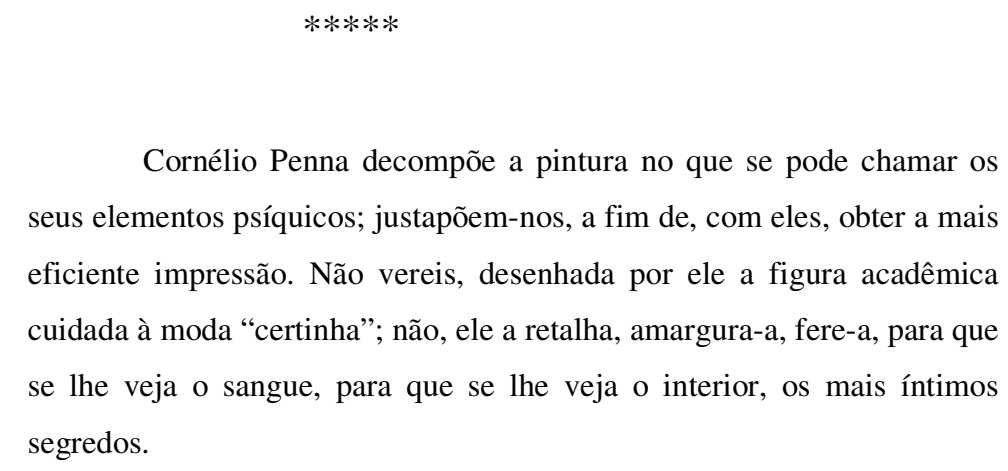

Adelino Magalhães

O momento mais característico e fecundo da pintura produzida por Cornélio Penna parece ser aquele em que adota "certa linha nervosa e trepidante, cujo grafismo erudito, personalíssimo, redimensionava integralmente os trabalhos dele, a partir da definição do novo perfil compacto da assinatura do artista". Essa linha "tremida", de “exasperada expressividade simbolista”, para continuar valendo-me das palavras de Alexandre Eulálio, "que avança num ziguezague irregular, de agora em diante vai comunicar poderosa sugestão dramática a tudo que ele esboça". Esse "traço, que parece provir da vibração constante de uma agulha de sismógrafo, permite a Penna expressarse com absoluta economia e insuperável rigor". Basta conhecer apenas um desses trabalhos realizados por Cornélio Penna para reconhecer que o pintor encontrou, no momento em que se preparava a grande exposição que teria lugar na Fundação Casa de Rui Barbosa, seu mais refinado e sensível crítico.

Essa linha ziguezagueante, plena de reentrâncias e anfractuosidades, tem em muitos casos um correspondente na figuração de homens marcados pelo desânimo, pelo pesar, pela angústia, pelo sofrimento e pela dor. Busque o artista representar índios ou caboclos, brancos ou negros, aparecem todos sempre soturnos, cabisbaixos, abatidos pelo desânimo e pelo cansaço ou dilacerados por dores atrozes e terríveis aflições. É

\footnotetext{
${ }^{11}$ Op. cit., p. 18.
} 
como se fora mesmo um sismógrafo que o artista parece captar os abalos, traumas e tremores que põem em pedaços o homem de seu tempo. Isso, porém, só é possível porque o que se reflete no olhar do artista encontra correspondências em seu interior, também marcado pela cisão, e essas fraturas acabam por se materializar de algum modo em sua obra.

Ora, isso parece entrar em contradição com o conceito de representação proposto por Luiz Costa Lima a que se fez referência, e mais de acordo com a visão da mímesis como imitatio. Ocorre que, assim como há diversas temporalidades num mesmo tempo, há muitas realidades na realidade que vemos ou acreditamos ver. Ainda depois de Freud e mesmo hoje, e a despeito ou por causa mesmo dos desconstrucionistas, o que prevalece é a noção de uma realidade inteiramente conhecida - e/ou passível de conhecimento -, expressa por uma linguagem transparente, e a de um homem uno e íntegro, dono de suas ações e senhor de si mesmo. A própria psicanálise teria de certo modo depurado a teoria freudiana de alguns de seus aspectos mais problemáticos e fecundos, como parece ter ocorrido com a pulsão de morte. Do mesmo modo que muitos não aceitam ainda hoje a teoria darwiniana da evolução, a noção de inconsciente, tal como proposta por Freud, lugar do desconhecido e do desconhecimento, do recalcado e dos representantes das pulsões, pressuposto da fragmentação do sujeito que independe de qualquer estado patológico ${ }^{12}$, encontra muitas resistências em pleno século XXI, que dirá no início do Novecentos. A obra do pintor Cornélio Penna, como a de muitos outros artistas, choca-se então com a realidade como é vista pela maior parte dos homens. Mantém com ela uma relação tensa e marcada pela diferença, sem deixar de aludir a uma outra realidade, menos visível e mais problemática, menos confortável e mais atormentada, cheia de angústias e caracterizada pelo desamparo do estar no mundo. Mesmo quando não utilizava aquela linha a que se refere Alexandre Eulálio, essa realidade já podia ser entrevista nos homens figurados pelo pintor, nos corpos contorcidos e faces transtornadas, nas cabeças baixas ou que se dirigem para o alto em mudas súplicas, nas mãos crispadas ou na mão que tenta cobrir o rosto ou segura a cabeça pendente, nos gestos de desespero ou de extrema fadiga, homens eventualmente acompanhados por personagens diabólicos, espectrais ou descarnados, quase sempre rindo ou gargalhando, enquanto aqueles se lamentam ou mergulham na melancolia e na

\footnotetext{
12 “A hipótese do inconsciente pressupunha, então, uma divisão do sujeito de caráter estrutural, pois transcenderia o campo da patologia mental e se evidenciaria na experiência psíquica normal através das formações do inconsciente.” (Joel Birman, Estilo e modernidade em psicanálise, p. 25.)
} 
tristeza. Essa "temática" precede aquele momento tão característico de sua obra e perdura até a composição de seu último quadro, "Anjos combatentes", ao mesmo tempo motivo e resultado da desistência da pintura.

O pintor desiste de pintar, mas não de olhar (para) o mundo. $\mathrm{O}$ artista desiste da pintura, mas não da arte. A literatura será o meio expressivo por que finalmente se decide. E não trará ela outros indícios da condição do homem fraturado? Não ficarão as fraturas desse homem de algum modo inscritas no conteúdo e sobretudo na forma dos romances $^{13}$, se é lícito ainda hoje aludir a essa divisão, já que haviam marcado indelevelmente suas retinas?

$* * * * *$

O uso relativamente freqüente por parte do escritor da palavra "inspiração" para falar do seu modo de escrever, ao tempo em que permite talvez aclarar aspectos importantes desse processo, pode dar margem ao equívoco de se acreditar na ausência de reflexão sobre o seu fazer literário e artístico. Dos depoimentos que chegaram até nós e a que pude ter acesso, é possível perceber que Cornélio Penna afirmava por vezes a relevância da inspiração em oposição aos "métodos" a que outros escritores, mesmo que de passagem, faziam alusão. Significativo nesse sentido é o depoimento a Ledo Ivo, em que Cornélio conta sobre uma viagem que teria feito a Itabira antes de publicar seu segundo romance:

- Um escritor muito lido - continuou Cornélio Penna - quando fui a Itabira em 1939, perguntou-me se ia colher material, se era o mesmo filão que ia explorar... Ri-me muito dessa idéia, e fui a Minas com esse espinho cravado em meu espírito, ainda mais que um jornal de Belo Horizonte disse que eu ia à procura de documentos humanos. Fiz um grande esforço para libertar-me do ridículo, pude viver lá momentos intensos e senti de novo toda a magia daquela gente, que representa para mim a alma livre do Brasil, poderosa e escondida na montanha. Não trouxe notas em meus cadernos de viagem, mas trouxe a vibração, o nexo espesso, surdo, das horas que vivera, e que faziam com que sentisse necessidade de

\footnotetext{
${ }^{13}$ Nas palavras de Antonio Candido: “... o externo (no caso, o social) importa, não como causa, nem como significado, mas como elemento que desempenha um certo papel na constituição da estrutura, tornando-se, portanto, interno." (Literatura e sociedade, p. 4.)
} 
escrever. E daí a publicação de Dois romances de Nico Horta. (Romances completos, p. LXXIV-LXV)

A uma escolha consciente, que implicaria decisão prévia sobre o tema ("o filão"), sobre o "material" que se buscará "colher" e sobre os "documentos humanos" que será preciso encontrar e conhecer para depois dar-lhes uma forma literária, Cornélio opõe a vivência de modo intenso, em que se torna possível sentir a vibração das horas e dos momentos vividos, a apreensão da magia e da alma da gente com quem assim se vive, sem um propósito imediato e deliberado. Ao contrário, essa experiência plena é que depois acaba por levá-lo à "necessidade de escrever", e assim nasce o romance.

O mesmo teria acontecido com sua última obra. Durante anos, o escritor convivera com o quadro da menina morta, herança de família, e com as recordações da grande fazenda do Vale do Paraíba, de propriedade da família da mãe, anos em que continuavam a preponderar as lembranças de Itabira, até que acabou um dia escrevendo um capítulo para Repouso que ao fim "destacou-se "dos demais

inteiramente diferente, com outro ambiente, com outra alma. Era a fazenda de café que se fazia ouvir, com sua voz murmurejante, onde o pranto dos escravos se mistura com a alegria da riqueza dominadora em marcha. E tive que excluí-lo e guardá-lo, mas não me foi possível conter tudo que aflorou em minha imaginação. Os velhos momentos vividos em Pindamonhangaba, o sangue materno, as recordações, os sentimentos que me tinham embalado, sobrepujados mas não vencidos pela força sobre-humana de Itabira, vieram à tona, e vou escrever outro livro, que se chamará simplesmente A Menina Morta. (p. LXV-LXVI)

E é desde o primeiro romance que a história se repete. Tendo morado em Itabira apenas durante um ano em tenra infância, para lá retornou em 1917, para "assistir à morte de minha avó paterna, a dona do Jirau”, permanecendo então por dois meses na cidade, mas a sua vida,

o espírito belo e sombrio de seus habitantes, as histórias de impressionante força de caráter, de invencível coragem no drama que tudo lá representa, tinham ficado gravadas em meu cérebro e em meu coração de tal forma, toda minha vida, que só pude me libertar de sua obsessão escrevendo. Pedi a muitos escritores que o fizessem, que se voltassem para o tesouro que representava a alma dos itabiranos, 
mas não consegui interessar a nenhum deles, e assim foi que escrevi Fronteira, que consegui publicar em 1935, e que representou para mim apenas um desabafo, uma confidência, ou melhor, uma confissão pública, a compreensão de Itabira. (p. LXILXII)

As palavras "confidência" e "confissão" sugerem uma fidelidade da obra à realidade vivida pelo próprio escritor que se encontra muito distante da verdade, não só em Fronteira como nos demais romances. Pouco mais de um ano depois da entrevista a Ledo Ivo, Cornélio parece declarar quase o oposto: “queria que os romancistas e homens de letras meus conhecidos escrevessem contando as histórias que eu sabia desde pequeno, mas ninguém quis, e assim resolvi escrever eu mesmo, mas ainda não contei nenhuma das confidências que recebi, ou que surpreendi, e daí os três livros, que até agora publiquei, não terem nenhum caráter pessoal ${ }^{\text {"14 }}$. Creio que aqui não se trata propriamente de incongruência de pensamento ou contradição. O que se desabafa ou se confessa é o espírito ou a alma de Itabira, isto é, o que se dispõe no romance, num arranjo inteiramente novo, em lugar de confidências pessoais, é a ambiência experimentada pelo escritor, desinteressado da verdade dos acontecimentos exteriores e da realidade do que de fato se passou ou se passava na cidade. Em outras palavras, a realidade vivida propiciou sentimentos e emoções que se traduziram depois numa obra literária que, embora lançasse mão de figuras que teriam realmente vivido na cidade em sua infância, é criação e ficção. As transformações e metamorfoses a que submeteu a experiência para chegar a essa "re-criação" podem ser conhecidas em maiores detalhes por meio de um texto escrito por Cornélio a pedido de João Condé para publicação nos seus “Arquivos implacáveis", na seção "Biografia do livro". Por ele, podemos conhecer o estado de espírito do escritor que, pelo menos na mesma medida em que a "alma" da cidade, impregnou de tal modo as suas recordações daquele tempo a ponto de marcar fundamente a composição do livro. A transcrição é longa, mas espero possa ser desculpada pela sua importância para um melhor entendimento do processo de composição, se é que assim podemos denominá-lo, empregado por Cornélio Penna:

No quarto muito amplo, no canto do fundo do enorme sobrado em que morávamos, com grandes e rudes janelas abrindo-se sobre o céu sem limites, pois a casa dominava uma ribanceira e era mais alta do que as outras mais próximas,

14 "Convite à literatura”, grifos meus. 
todos os meus se refugiavam, em um só dormitório, pois meu pai falecera pouco antes, e toda a família ficara em indescritível desamparo moral. Vivíamos um lento pesadelo, mutilados todos com a ausência daquele que enchera as nossas vidas e se fora de repente, deixando-nos sem pátria, pois sentíamo-nos fora do mundo, estrangeiros que falavam uma língua subitamente desprovida de sentido, e nossos gestos não tinham mais significação. Essa sensação de automatismo, de ausência, que conservamos todos, e que nos fez suportar as mortes que há poucos anos nos feriram, privando-nos daquela que foi tudo para nós, o nosso lar e a nossa proteção, e o primeiro dos irmãos que a seguiu, ainda perdura, e nos desarmou inteiramente diante da vida. Assim, o menino subir à sua cama, para ver de longe o enterro da Mulher Santa, que reunia toda a população de Itabira, e de seu posto de observação, tendo um vale de permeio, ver as figuras brancas que seguiam a margem do barranco, muito lentamente, surge como um sonho, interrompido pela sensação aguda de dor, que senti no joelho. Alguém deixara uma agulha vulgar de "crochet" sobre minha cama, e foi com pavor que vi o sangue correr, e tudo se confunde nessa impressão de perigo e de rostos inquietos e mãos tateantes. Já ouvira muitas vezes contar as singularidades, os chamados milagres da Mulher Santa, mas eram episódios em minha imaginação, que se reuniam aos outros, os da princesa de cabelos verdes e olhos cor-de-rosa, os da velha que saía à noite, para acompanhar uma procissão, que depois verificara ser inteiramente composta de mortos e que me eram contados por Chica, a nossa velha ama, mas creio que o ferimento, e a cicatriz que me ficou, deram dolorosa realidade à figura da pobre doente, que se tornou para mim em antiga e vagarosa obsessão. ${ }^{15}$

E o escritor prossegue o relato com a recorrente história do modo como, ainda tãosomente pintor, buscava interessar os amigos escritores a escrever sobre a "Mulher Santa", sem sucesso, acrescentando agora o nome de dois deles: Aníbal Machado e Raul Bopp, que o olhavam então entre divertidos e embaraçados. A acreditar nesse depoimento, e aparentemente não há por que não fazê-lo, tudo que vivenciou na infância em Itabira junto da família está presente em Fronteira, ao mesmo tempo em que nada deixou de ser em grande medida re-trabalhado e re-criado literariamente: a tristeza, a angústia, o desamparo, o pesadelo, o sentimento de serem todos estrangeiros a falar uma língua estranha e incompreensível, o automatismo, tudo se encontra no romance, nos sentimentos atribuídos aos personagens, sobretudo ao narrador-

${ }^{15}$ O Cruzeiro, 9 de outubro de 1937, Roberta de Castro Sampaio, Os arquivos implacáveis de João Conde: edição fac-similar acompanhada de estudos e notas. 
protagonista e a Maria Santa. A agulha de crochê que fere o menino ressurge depois, transformada nas agulhas com que os visitantes espetam o corpo inerte da Santa. Ainda que realmente fossem narrados episódios como esse ocorridos com a Mulher Santa, a coincidência com o seu ferimento só pode ter deixado a criança ainda mais impressionada, pronta depois a fazer desse "milagre", e não de possíveis outros, um dos motivos centrais do romance.

Talvez ainda antes do abandono das artes plásticas, Cornélio escreve um texto relativamente longo a pedido de Adelino Magalhães sobre o tema "motivos brasileiros de pintura" $"$. Nele, depois de criticar a "orientação emprestada", que leva ao surgimento de quadros "insinceros, amaneirados, que nos parecem inexplicavelmente frios e banais", Cornélio Penna afirma a necessidade da reivindicação da independência dos pintores, e de que eles "não sejam mais unicamente os intérpretes do pensamento alheio, mesmo que ele seja da Religião, da História, ou da Natureza”. E então, aquele que depois irá justificar o abandono da pintura porque fazia "literatura pintada", encarece a necessidade da "educação literária" por parte dos pintores brasileiros. Mas o que interessa mais de perto aqui são os três motivos que, segundo ele, se apresentavam, aos artistas plásticos, "impressionantes em sua rude beleza: o Caboclo, o Índio e o Negro”. E depois insistia:

Sondemos o segredo de nossas pequenas cidades sertanejas, que dormitam ao sol rutilantes, com suas calçadas de lajes tumulares, suas crises de misticismo fatal, suas ruas construídas ao sabor das enxurradas e das estradas cortadas pelas tropas e pelas boiadas, com seus crimes estranhos, suas casas espectrais e seus preconceitos imprevistos e cruéis.

Se aquelas recordações da infância não participassem da história "biográfica" de um livro, mas fossem simples rememoração, ainda assim seria difícil não reconhecer nelas a ambiência de Fronteira. Do mesmo modo, não há como não ver a Itabira dos três primeiros romances na descrição das "cidades sertanejas" dessas considerações sobre a pintura. A cada uma dessas menções - as lajes tumulares, o misticismo, as ruas, as enxurradas, as tropas e boiadas, os crimes, as casas espectrais, os preconceitos -

\footnotetext{
${ }^{16} \mathrm{O}$ manuscrito, sem data, encontra-se no acervo do escritor junto ao Arquivo-Museu de Literatura Brasileira da Fundação Casa de Rui Barbosa.
} 
poderiam ser encontradas passagens correspondentes dos romances. A sugestão dos motivos brasileiros para os pintores é tomada para ele próprio quando se decide pela literatura $^{17}$, e aí se vê como, ao lado da inspiração, propiciada pela vivência e pelas recordações, atua um esforço consciente de representação de um determinado homem e uma determinada "paisagem". Esta vem entre aspas porque não tem em Cornélio nenhuma independência em relação àquele. A sua literatura parece ainda aqui seguir o que aconselhara aos pintores:

Julgo, portanto, que os verdadeiros "motivos brasileiros" só os encontraremos no próprio homem, e nada direi da paisagem brasileira, nem da estilização de nossa natureza. Não é possível compreendê-las sem compreender aquele que as anima e lhes dá o cunho inapagável de sua dor e de sua alegria.

Lado a lado com o inescapável da obsessão, nota-se assim a existência de uma opção consciente por um determinado homem e determinada cidade, naquilo que escritor se referia como "Itabirismo", em artigo publicado na revista O Cruzeiro. Na ilustração realizada pelo próprio Cornélio, que cobre o triângulo do lado esquerdo formado por um corte da folha no sentido diagonal, de baixo para cima e da esquerda para a direita, como o narrador de Fronteira e depois Urbano, em Repouso, chega à cidade um cavaleiro e sobe a rua em ladeira calçada de pedras lascadas, que no entanto semelham mais touças de espinhos pontiagudos. Montado, deixa pender o corpo um pouco para trás e, completamente cabisbaixo, como se carregasse um peso incomportável, para usar uma palavra cara ao escritor, parece evitar olhar para as casas acima e à frente. Numa delas, uma outra figura, encostada à parede, de joelhos dobrados, igualmente cabisbaixa, também não olha na direção do cavaleiro, embora voltada na sua direção. Ao lado desta, mais abaixo, vê-se o telhado imponente de outra casa, bem como uma de suas grandes janelas. Entre ambas, salta o galho de uma árvore, acima do homem a cavalo, na direção da margem esquerda da folha. E, finalmente, na parede perpendicular àquela em que o personagem se encosta, uma touceira, mas que

\footnotetext{
17 Infelizmente, acabei tratando muito pouco neste trabalho da temática do índio nos romances cornelianos. Muito menos freqüente que o negro, quando ele aparece é quase sempre como ausência em meio à culpa pelo seu extermínio. Para um melhor tratamento dessa questão remeto o leitor ao belo ensaio de Luís Bueno, que comenta e interpreta uma passagem de Fronteira e uma outra de Nico Horta em que esse tema se faz presente. ("Cornélio Penna", Uma história do romance de 30.) V. também o estudo de Josalba Fabiana Santos, que tece reflexões semelhantes sobre a mesma questão: "Dos esquecimentos da história, um que Cornélio não comete é o de negligenciar a memória da presença índia”. (Fronteiras da nação em Cornélio Penna, p. 46.)
} 
também mais parece grande fogueira em chamas. Encimando tudo isso e sobrepondo-se aos dois triângulos, a palavra "ITABIRISMO", assim mesmo, em caixa-alta, mas com cada uma das letras com reentrâncias e cortes dos dois lados e mesmo no interior, e ainda a característica assinatura do pintor, PENNA. O texto, reproduzido no triângulo oposto ao da ilustração, tenta explicar a opção por Itabira, no mínimo curiosa para aqueles que crêem ser o Rio de Janeiro ou São Paulo "a capital do Brasil”:

Para mim, a nossa metrópole, de onde tudo devia irradiar - e há de chegar esse dia -, de onde tudo deve partir, é Itabira do Mato Dentro, com a sua prodigiosa cristalização da alma brasileira, de sua consciência e de seu princípio essencial.

Chamando-a "verdadeiro tesouro do Brasil", depois de afirmar a consciência de que ela se encontra ameaçada de destruição, Cornélio Penna passa a expor os motivos por que ela seria tão valiosa, mas é em vão que criamos expectativas de obtenção de respostas muito claras ou precisas: "Quem melhor do que ela poderá ensinar a arte complexa de ser infeliz, a alegre ciência da renúncia e da humildade?" De todo modo, e a despeito do truncado da cópia, a única que pude obter, percebe-se que a preferência do escritor por Itabira oscila entre o afetivo e o conscientemente eleito. É nessa mesma oscilação que Cornélio elegerá o negro - um dos motivos sugeridos aos pintores - como figura fundamental de seu último romance, ao lado do quadro da menina morta e da fazenda de café. E é também nela, por fim, que acredito encontrar-se uma possível resposta para o encaminhamento dos romances cada vez mais na direção do passado. O gosto pelas coisas antigas, o afeto dedicado aos objetos antiquados, a ponto de colecioná-los, liga-se à reflexão sobre a importância da volta ao passado para o conhecimento da "alma brasileira", para nos dar o autor dos "romances de antiquário", na expressão tão conhecida de Mário de Andrade. Nesse sentido, teria atuado então, ao lado da evidente falta de gosto pelo próprio tempo, a convicção da perda de sua alma.

Tensão das mais características encontra-se no interior mesmo da linguagem e em outros aspectos formais dos romances cornelianos. Procurei mais de uma vez apontar ao longo das análises de cada um dos romances momentos em que o cuidadoso trabalho com a linguagem mostrava-se de maneira inequívoca. $\mathrm{O}$ fato de ter publicado apenas quatro romances, e ainda a relativamente largos intervalos, sugere o trabalho 
lento e paciente em sua composição ${ }^{18}$. Pude mesmo testemunhar as inúmeras correções e alterações que foram feitas em Fronteira e A menina morta antes de sua publicação. Na Fundação Casa de Rui Barbosa, tive acesso aos originais desses dois romances, embora por período relativamente breve devido ao escasso tempo que me restava para permanecer no Rio de Janeiro, o que mesmo assim não obstou um vislumbre do "método" corneliano. Nos originais de Fronteira, em sua maior parte datilografados no verso de papel timbrado do Ministério de Estado da Justiça e Negócios Interiores, parecendo ser não propriamente originais, mas cópias feitas com o uso de papel carbono, embora houvesse algumas páginas manuscritas, encontram-se numerosas correções, algumas a lápis e outras, a tinta. Foi, porém, diante dos originais de A menina morta, com as páginas datilografadas e encadernadas, que fiquei mesmo espantado diante das inúmeras correções e retificações a lápis ou ainda à máquina. Praticamente não há linha sem algum tipo de modificação - cortes, acréscimos ou substituições. Algumas dessas alterações são de ordem gramatical, como a substituição do gerúndio por outras formas verbais, mas há também mudanças relativas aos nomes dos personagens. Algumas delas parecem ter ocorrido durante a escritura do romance; outras, depois de terminada. Carlota chamava-se inicialmente Maria Efigênia, mas era quase sempre referida como "Sinhazinha". Dona Virgínia era Maria Delfina ou Dona Delfina, mas seu nome não se encontra alterado, tendo sido modificado talvez apenas no momento de verificação das provas. Sinhá Rola era chamada de Eufrosina, e teve o nome trocado apenas no início dos originais. Manuel Procópio tinha como primeiro nome o do próprio escritor: Cornélio Procópio. Dona Maria Violante era Dona Maria de Paula; o Senhor Justino, Jesuíno; e o Padre Estevão, Padre Lopes. E dentre os escravos, Joviana inicialmente chamava-se Justina. E até mesmo a fazenda teve o nome alterado de Cortiço, que era o nome original da fazenda pertencente à família da tia materna e que teria sido a fonte de inspiração do escritor na criação da propriedade do Comendador, para Grotão. O mesmo talvez pode ter ocorrido com alguns personagens, isto é, os primeiros nomes utilizados podem ter sido os daqueles que inspiraram a sua criação. Como nada pude obter a esse respeito, trata-se apenas de especulação e nada impede serem aqueles primeiros igualmente fictícios. De todo modo, a impressão (e é apenas isso, não tendo nenhuma resposta mais objetiva para tal sentimento) que tenho é de que, na maioria dos casos, a mudança parece ter sido para melhor.

18 "O estilo não trai nenhuma pressa, nenhum desejo de acabar." (Antonio Carlos Villaça, "A menina morta".) 
Tudo isso parece contrastar de modo profundo com as declarações do próprio escritor sobre a suficiência do dom ou o deixar-se "dominar pela inspiração", ou ainda com a afirmação de que "aquele que procurar burilar-se, que estuda com o fim determinado de aperfeiçoar-se, de fazer de si mesmo um instrumento afinado e dúctil para a produção da arte, é um produtor e não um artista"19. O que poderia ser visto como despistamento, na melhor das hipóteses, ou como falseamento, na pior, é de fato insolúvel contradição. É dela que resultaram aspectos da obra que foram vistos como defeitos, por uns, ou qualidades, por outros, e que ora é mesmo uma coisa ou outra, mas às vezes é uma coisa $e$ outra, de todo modo, num como noutro caso, é sempre um problema a ser pensado, ainda que nem sempre se possa chegar a alguma conclusão pacífica e indiscutível.

É por isso que mesmo críticos que reconheceram grandes qualidades na obra corneliana, inclusive do ponto de vista da linguagem, mostraram-se ao mesmo tempo inconformados com alguns "cochilos" do escritor. Assim, Sérgio Milliet, depois de afirmar que "entre os nossos romancistas de renome [Cornélio] é o que melhor sabe adaptar a forma ao fundo", refere-se aos seus "descuidos [que] não se justificam em quem tem um senso tão agudo de sua responsabilidade de escritor", como o uso do verbo tornar duas vezes no mesmo tempo verbal e na mesma frase, e depois por mais quatro vezes em apenas duas páginas. Fausto Cunha, por sua vez, fala da abundância da adjetivação e de algumas "expressões decadentes" ou mesmo de "gosto dúbio". Não tive nenhuma confirmação disto, mas estou quase certo que foi devido a alguma crítica feita ao livro de estréia que o escritor se decidiu pela substituição, em geral por adjetivos e particípios, de boa parte do número exagerado de gerúndios presentes na primeira edição de Fronteira. Segundo nos informa nota constante da edição da Artium, 294 (!) gerúndios teriam sido modificados. O fato de se poder encontrar o mesmo tipo de alteração nos originais do último romance sugere que mantinha o hábito de empregálos com relativa freqüência e que a crítica recebida pelo exagero desse uso não perdera ainda o efeito.

Quando da abordagem de Repouso, fiz referência ao "problema" - já notado por Fausto Cunha - de se tratar de um romance que parte da evocação de um personagem Dodôte - mas que se desloca depois - contrariando todas as expectativas do leitor para a interioridade de um outro personagem - Urbano. Mas falar aqui em defeito (o

\footnotetext{
${ }^{19}$ Romances completos, p. XLVII.
} 
que não é propriamente o caso de Fausto Cunha) é não reconhecer que já no século XIX alguns romancistas absolutamente não se preocupavam com esse tipo de verossimilhança. Para mencionar um deles, mas dos maiores, o Dostoiévski de $O s$ demônios não demonstra o menor receio em fazer o seu narrador-personagem transformar-se de repente em narrador onisciente, conhecedor do que se passa em situações em que não podia estar presente, como testemunha, e mesmo no interior de outros personagens, passando depois disso a mesclar - sem diferenciá-los - momentos em que o narrador se refere à sua participação na história, a conversas com outros personagens, ao caráter testemunhal do relato, e outros em que não há como não pressupor um narrador onisciente, e nem procura fornecer qualquer justificativa ou subterfúgio para tal "incongruência". Saber que o romance foi publicado em folhetins e principalmente que foi baseado em fatos reais e escrito, quase literalmente, no calor da hora não explica tudo, e talvez não explique nada do que se refira à escolha do escritor por uma narração tão pouco convencional. E o "problema" em nada afeta o impacto causado por obra tão densa, o sentimento de nos encontrarmos diante de uma obraprima, revolucionária e quase profética em relação ao drama terrível que a humanidade iria enfrentar no século $\mathrm{XX}^{20}$. Restaria mesmo saber se o "desconcerto" dessa narração antes não reforçaria esse impacto e esse sentimento, à medida em que tematiza um homem possuído, tomado pelos demônios, e um mundo desordenado e como que virado do avesso.

A aparente desordem (Fausto Cunha fala em dualidade ou dubiedade [da] construção) da narração em Repouso não poderia assim ser vista como o dilema dos escritores modernos, que "receiam impor à vida, ao seu tema, uma ordem que ela própria não oferece" ${ }^{, 21}$ ? Haveria assim um mal-acabamento, um "desequilíbrio da forma" ${ }^{, 22}$, que não pode ser reduzido a defeito, que - conscientemente ou não - remete a um mundo sem sentido e sem lógica, refratário a qualquer ordenação que não seja aquela imposta pelo capital.

Inconsistências desse tipo podem ser encontradas não só em Repouso, mas como já foi visto - em todos os outros romances. Em Fronteira, nos personagens misteriosos e imotivados; em Dois romances de Nico Horta, sobretudo no personagem Pedro, que começa como o outro de Nico Horta, para depois tornar-se tão semelhante a

\footnotetext{
${ }^{20}$ V. Paulo Bezerra, "Um romance profecia”, posfácio a Os demônios, obra traduzida por ele do russo para o português.

${ }^{21}$ Erich Auerbach, Mimesis, p. 494.

${ }^{22}$ Observação feita durante o exame de qualificação pelo prof. Ariovaldo José Vidal.
} 
ele; n' A menina morta, na descrição minuciosa de tudo, no conhecimento detalhado da história e dos sentimentos dos agregados, ao lado do desconhecimento quase completo do que se passa com os proprietários; e ainda, em mais de um romance, na introdução de histórias curtas que, se não destoam da temática dos romances em que se encontram encartadas, são vazadas numa forma inteiramente diversa, como o episódio dos Bexiguentos, em Fronteira, e o do "quarto da mão negra", em Repouso ${ }^{23}$.

De Itabira ao Vale do Paraíba, do passado relativamente recente ao passado mais distante, foi na esteira desses deslocamentos espacial e temporal que Cornélio Penna escreveu seus quatro romances. E, para dizer uma vez mais, parece-me que a realização de sua obra pode ser vista como reiterados ensaios em que o escritor aperfeiçoa a sua prática até chegar à escritura de $A$ menina morta, em que a composição se resolve da maneira mais adequada. Não significa dizer que haja uma linha ascendente num sentido estreito de evolução ou progresso. Ao contrário, Fronteira é sem dúvida um melhor romance que Dois romances de Nico Horta e mesmo Repouso, para alguns, não lhe parece superior. Ocorre que, a partir do segundo romance, o escritor opta por narrar em terceira pessoa e nesse sentido Nico Horta pode ser visto como um ensaio dessa utilização, com evidentes problemas e momentos bastante desiguais. Em Repouso, problemas e desigualdades diminuem bastante sem serem eliminados de todo, e no último romance o escritor parece ter obtido um maior domínio da técnica narrativa e uma utilização mais adequada da terceira pessoa.

Do ponto de vista da representação, se tivermos em mente as noções de homem fraturado e de mímesis como diferença, as figuras do Comendador e de Dona Mariana, n' A menina morta, o primeiro levado à morte e a segunda, ao enlouquecimento, depois de uma vida a dois marcada por mútua incompreensão e por ódio recíproco, a despeito (ou por causa) da riqueza e do poder, essas figuras dramatizam admiravelmente os dilaceramentos humanos. O fato de que sua história transcorra na segunda metade do século XIX não só não inviabiliza a associação deles com o homem da primeira metade do século $\mathrm{XX}$, como alude, se não propriamente às origens, a um período fundamental para o agravamento dessas fissuras. Como foi visto no momento da análise do último romance corneliano, a produção cafeeira em larga escala baseada no trabalho escravo não se opunha, mas ao contrário se unia estreitamente ao capitalismo em expansão,

\footnotetext{
${ }^{23}$ Quem me chamou a atenção para essa “incongruência” foi Ayde Veiga Lopes.
} 
união aliás fundamental para esse movimento expansionista, que vai fazer recrudescer nas décadas seguintes, no Brasil, ainda que com algum atraso, e no mundo, na medida mesma do desenvolvimento acelerado dos bens materiais e da tecnologia, a violência, a exclusão, a insatisfação geral, o desamparo, as fraturas do sujeito. Mas, ainda que se atenha aqui a um outro modo de ver a representação - que de alguma maneira mantém a noção de semelhança, embora a amplie ao tempo em que a torna mais complexa, e sem absolutamente recusar a "realidade autônoma" da obra -, advindo das reflexões de Gadamer, que a compreende como um processo ontológico que permite ao representado ser "enfim o que inteiramente é" 24 , parece inegável que $A$ menina morta constitui o mais importante romance do escritor. Como foi visto, o espectro social é muito mais amplo aí do que nos outros romances, e a escravidão e a figura do negro - presentes ao longo de toda a produção corneliana - só então assumem o primeiro plano e ganham uma profundidade de tratamento única. Outros temas, contudo, continuam onipresentes, ligados não só aos senhores como aos agregados e escravos: o estranhamento, a angústia, a incomunicabilidade, o preconceito, a loucura, os crimes, a morte, a decadência etc. Contudo, seria difícil talvez discordar da afirmação de que um tema como a loucura comparece de modo ainda mais intrigante no primeiro que no último dos romances. Sem apresentar um desencadeamento mais preciso ou uma motivação de todo compreensível, a loucura em Fronteira parece - exatamente por isso - mais contundente e paradoxalmente mais próxima da realidade. Aqui o pensamento de Gadamer poderia ser chamado uma vez mais para embasar essa leitura, pois ele também vê a representação como "auto-compreensão": "O que propriamente experimentamos numa obra de arte e para onde dirigimos nosso interesse é, antes, como ela é verdadeira, isto é, em que medida conhecemos e reconhecemos algo e a nós próprios nela." ${ }^{25}$ Um

\footnotetext{
${ }^{24}$ Verdade e método, p. 204.

${ }^{25}$ Idem, ibid., p. 119. Especialmente ao falar da "verdade" da obra de arte, a afirmação de Gadamer parece inteiramente diversa daquelas de Luiz Costa Lima transcritas no início deste capítulo. Muitas outras formulações, aliás, parecem mesmo questionáveis e teriam desencadeado a grande polêmica travada entre Habermas e o autor de Verdade e método, como aquelas a respeito do "preconceito", da tradição e da arte clássica. (v. Luiz Costa Lima, "Hermenêutica e abordagem literária", Teoria da literatura em suas fontes.) Nada disso, contudo, retira a importância dessa obra seminal. Para ilustrar a complexidade e o intrincado dessas questões, basta dizer que, mais do que em Costa Lima, a insistência de Gadamer na representação e em sua verdade tem nos desconstrucionistas sua exata antípoda, sendo que ambos teriam partido, provavelmente aquele mais do que estes, do pensamento de Heidegger. Ainda aqui, as contradições do homem e de seu pensamento encontram em Luiz Costa Lima (que aliás começa seu livro com a crítica a um pensamento de Heidegger) uma excelente formulação, ao tratar do encontro entre o poeta Paul Celan, cujos pais morreram vítimas do Nazismo, e o filósofo Martin Heidegger, em que aquele esperava deste, que tanto admirava, palavras que condenassem o Holocausto, palavras que no entanto não vieram: "O próprio Heidegger, cujo silêncio agrava a ferida do visitante, não tem por isso
} 
pouco mais ou pouco menos, haverá alguém que possa dizer nunca ter se aproximado de algum modo da loucura, não uma inteiramente explicada e explicável, que pode assim ser chamada doença e que prevê uma cura, mas de uma outra, de todo gratuita e vinda "do nada", parte apenas do que é inerente ao homem?

A opção do escritor pela terceira pessoa, como toda escolha, implica obviamente um ganho e uma limitação. É por isso talvez que Cornélio Penna, tendo chegado a um resultado bastante satisfatório na utilização da terceira, como que ensaie o retorno à primeira pessoa no romance que deixou inacabado, Alma branca. Segundo a "Nota preliminar" que introduz dois fragmentos desse romance na edição dos romances completos da Aguilar, "o autor parecia ainda não haver se decidido acerca do "ponto de vista' que adotaria, pois aparecem passagens em primeira e outras em terceira pessoa”. Dos dois fragmentos transcritos nessa edição, um encontra-se em terceira pessoa e o outro, em primeira. Ainda nessa nota, pode-se ler uma observação sobre o método do escritor:

Em vez de redigir seguidamente, de acordo com o desenrolar da intriga, lançava ao papel pedaços isolados, como se inspirado por jatos, depois costurava os retalhos, fazendo montagem, harmonizando o todo segundo o esquema que traçara, e submetendo ainda a composição a numerosas correções de estilo e expressão, bem como a ajustamentos técnicos e estruturais.

Mesmo para quem não tem ou teve acesso aos originais, o "método" descrito nos Romances completos poderia ser confirmado pela valiosa edição da Artium de Fronteira, cujo texto teria sido fixado a partir do cotejo entre a primeira e a segunda edições, respectivamente da editora Ariel (1935) e Edições O Cruzeiro (1953), e ainda aquela dos Romances completos, da Aguilar (1958). Dentre essas alterações encontramse as modificações do gerúndio, como foi mencionado, e "o remanejamento de diversos parágrafos na reestruturação dos capítulos XII, XXIV e XXV.” A respeito desse último, consta no final do livro uma página dupla com gráficos coloridos que ilustram cada um dos remanejamentos empreendidos pelo escritor, que efetivamente comprovam o modo como Cornélio Penna trabalhava, ainda que possa soar como um certo exagero falar em "costura de retalhos", parecendo mais adequada a expressão "montagem" ou 
"remontagem" do texto. Por outro lado, é graças às mudanças relativas ao gerúndio que se pode ver apenas como despistamento a indecisão do suposto editor do manuscrito quanto ao sexo do narrador-protagonista de Fronteira, no que é, salvo engano, a única ocasião em que Cornélio Penna inadvertidamente acaba por revelar que se trata mesmo de um homem, ao substituir um gerúndio pelo particípio ${ }^{26}$. A existência desse único momento deve chamar nossa atenção não para um provável "cochilo" do escritor, mas para o empenho com que buscou "ocultar" essa informação ao longo de todo o romance.

Um dos aspectos mais característicos de toda a obra corneliana é o jogo de luz e sombras, o claro-escuro que acaba por evocar de algum modo o imaginário barroco presente, mais talvez do que em qualquer outro lugar do país, no interior de Minas Gerais, "palco" de seus três primeiros romances. Todavia, uma das passagens mais significativas desse contraste entre a luz e as sombras encontra-se n' A menina morta, na descrição do interior da matriz de Porto Novo, em pleno Vale do Paraíba:

A matriz fechou-se. A escuridão a invadiu de um só golpe e formou-se um bloco negro, impenetrável de treva e de silêncio... Pouco a pouco um raio de luz tremeu e infiltrou-se pelas frinchas da porta lateral onde o sol batia de chapa na madeira já carunchada sob a pintura cor de oca toda ressequida e estalada e difundiu ondas doces e longas de claridade, transformando a treva que parecia invencível em penumbra onde lentamente surgiam os vultos dos santos, dos confessionários e dos grandes bancos. Aqui e ali um reflexo respondia ao toque luminoso e fazia reluzir pontos de luz móvel como silenciosos vaga-lumes sob a abóbada das árvores lá na floresta, que se acendiam e apagavam trêmulos e deles seria difícil distinguir a pequena chama avermelhada do lampadário de prata que velava junto do Santíssimo. Bem perto dele estava a pedra com os sinais muito novos ainda do reboco e da argamassa que tinham sido postos para calafetar o carneiro onde fora encerrado para sempre o corpo da menina morta. (p. 57)

A escuridão inicial faz-se matéria espessa no interior da igreja, corporifica-se num bloco inteiramente sólido feito de ausências: a da luz e a do som. Mas o que se pensava impenetrável deixa-se aos poucos penetrar pelos raios da luz solar que, em vez

\footnotetext{
26 “ 'Mas quem me libertará? - continuei, mais animado - não posso inocular-lhes o meu sofrimento, e isso não me curaria.” (p. 171, grifo meu) Em nota de rodapé, encontra-se a observação de que na edição princeps (EP), de 1935, constava "animando-se" em lugar de "animado".
} 
de tentarem derrotar a penumbra pela força, se difundem em "ondas doces e longas", atuando por assim dizer mais por meio da sedução do que pelo enfrentamento, até obterem a vitória sobre "a treva que parecia invencível". Essa conquista, porém, não é completa e muito menos definitiva: a imagem dos vaga-lumes sugere a posterior alternância entre luz e sombras no interior do templo, além de estabelecer certa homologia entre esse ambiente sagrado e a mata fechada que se estende fora dela: "a abóbada das árvores lá na floresta”. Por fim, perto do Santíssimo alumiado por pequena chama avermelhada, descreve-se a pedra que cobria o caixãozinho da menina morta, totalmente calafetada com reboco e argamassa, de modo a tornar interdita "para sempre" a entrada da luz no interior do túmulo, onde - aí, sim, impenetráveis e invencíveis - passavam a reinar de modo absoluto as trevas e o silêncio.

Como em diversos outros momentos, não só de A menina morta mas de toda a obra corneliana, os jogos de luz e sombra apresentam-se como embates e conflitos nunca terminados de todo, a não ser por ocasião da morte, em alternâncias que guardam alguma correspondência tanto com o drama interior dos homens como com as lutas que se dão entre eles. É assim que a narração prossegue referindo-se às “centenas de preces, de suspiros e de gritos de angústia, de confidências e de súplicas ditas ora com imperioso desespero ora em ciciar humilde" que constituíam a alma do templo. Uma vez mais, especialmente ao mencionar que a "menina era (...) levada para o alto", são nítidas as referências religiosas e aos credos cristãos e católicos. Mas também aqui não há como não reconhecer o propriamente humano de que participam todos os homens, independentemente da fé ou da ausência dela. O desamparo é o de todos, assim como a angústia, que não parece ter fim mesmo para aqueles que crêem.

Essas imagens de luz e sombra, como foi dito, são bastante recorrentes em Cornélio Penna. Em Fronteira, numa cena que se procurou analisar de modo relativamente exaustivo, vimos como esse contraste surge também dentro de uma igreja, em que o narrador-protagonista entra quase sem se dar conta disso. No mesmo romance, no interior do casarão castigado pela tempestade, o narrador vê "a multidão negra e embuçada [que lá se encontrava para presenciar os milagres da Santa], que os relâmpagos faziam surgir bruscamente nas trevas, e que depois recuava, para desaparecer de novo atrás dos vidros embaciados..." Uma vez mais, alternam-se a luz e a escuridão, sem que uma predomine sobre a outra, agora porém com a ação da primeira sendo exercida em golpes vertiginosos sobre a segunda, que avançam e recuam de modo muito rápido e certeiro. E novamente esse embate surge em meio à alternância - de 
maneira aqui igualmente veloz - entre silêncio e som, pois a multidão desaparecia ao mesmo tempo em que cessava "o ribombo dos trovões".

A cena da entrada casual na igreja repete-se em Repouso, marcada de novo pelo claro-escuro $^{27}$, mas há um outro momento nesse romance em que o embate que travam parece uma luta de vida e morte e em que as sombras ganham ainda mais concretude do que naquele quadro da igreja do último romance:

Abria [Dodôte] sucessivamente as portas e as janelas que encontrava em seu caminho, e tentava respirar o vento livre que devia vir das montanhas. Mas tudo estava parado, e a noite espessa, de negror impenetrável, cercava a Ponte com suas muralhas.

A luz trêmula e crepitante da vela que trazia na mão suscitava fantasmas em todos os cantos e os fazia dançar um bailado fantástico de morcegos e aves noturnas, cujas asas se abriam e se fechavam rapidamente, em movimentos insensatos.

Algumas vezes a sombra, escondida atrás da porta que abria, tomava vulto e avançava para ela, e a chama quase morria na torcida sem espevitar, antes que Dodôte a abrigasse com os dedos. E continuava a fuga precipitada, como se mil fantasmas silentes a assaltassem. (p. 337)

Aqui os contrastes provocados pelo claro-escuro são também responsáveis pelas visões sinistras e fantasmáticas que perseguem o personagem sem descanso. Ocorre que esses fantasmas não são senão projeções dos tormentos interiores do sujeito dividido: "Um mau companheiro devia segui-la pelas salas e pelos quartos, ... // Quem é você? perguntou com voz amarga e gelada à sua própria aparência, que sentia separar-se de seu corpo, ...” O efeito produzido diante dessa descoberta não é absolutamente o de recuperação da paz e da serenidade, mas o do recrudescimento da inquietação, pois tais fantasmas tornam-se ainda mais assustadores e terrificantes quando se percebe que se encontram no próprio interior e, portanto, muito mais difíceis de serem banidos e exorcizados. Em outro momento do romance, explicitam-se as correspondências entre o claro e o escuro e entre o som e o silêncio que o sujeito vê e ouve no mundo e aqueles que se encontram em seu interior, num jogo de projeções do interno sobre o externo e vice-versa, ao mesmo tempo em que se associam trevas e silêncio - que, ainda antes da

\footnotetext{
${ }^{27}$ P. 107 e sgs.
} 
chegada da morte, aparentam ter vencido de vez a batalha e a guerra contra a luz e o som - ao medo e ao desamparo:

A casa, em torno dela, voltou ao silêncio pesado em que estava mergulhada, e tudo morreu nas trevas. Seus olhos escureceram e apagaram-se aos poucos, e naquele canto tudo era sombra, pois também ela era apenas uma sombra entre as outras...

Mas no fundo de seu cérebro anuviado, vivia e latejava o medo, como único princípio de vida, na sala morta, na grande massa sombria da casa, na cidade toda negra, e lá fora. (p. 295)

São assim essas lutas infindáveis entre a luz e as sombras homólogas àquelas que se dão no interior do homem, quando se digladia consigo mesmo, e entre os homens, quando batalham uns contra os outros. E é nesse sentido, e não apenas na utilização formal do claro-escuro, que a literatura corneliana parece aproximar-se do imaginário barroco para dramatizar não mais os conflitos do Seiscentos ou do Setecentos $^{28}$, e nem mesmo aqueles próprios do Oitocentos, em que transcorre a história de A menina morta e a de alguns ou de todos os outros romances, mas aqueles de seu próprio tempo, constituídos não só pelos dilemas que atravessaram todos esses séculos e permaneceram relativamente intactos ou ainda se agravaram, como pelos embates próprios do século XX. Nesse sentido, as palavras de Nicolau Sevcenko para caracterizar o Barroco brasileiro me parecem muito significativas quando pensadas em relação à onipresença do claro-escuro em Cornélio Penna, se é que não possam contribuir também para a reflexão de sua obra como um todo:

Estética dos contrários, sua linguagem multifária, sua dinâmica espiralada, suas energias fluidas e dispersivas, ao mesmo tempo afastam as partes e as articulam numa configuração mais instável, mas ainda assim agregativa e heteróclita, as diferenças se pronunciam sem se anular, se manifestam sem se absorver umas às outras ou se sufocar mutuamente. Não podendo recompor o que se estilhaçou, o Barroco dramatiza a alienação, o conflito e a dor, expondo a hubris que corrói a sociedade no mesmo gesto com que expurga as forças destrutivas. ${ }^{29}$

\footnotetext{
28 "No Brasil houve ecos do Barroco europeu durante os séculos XVII e XVIII: Gregório de Matos, Botelho de Oliveira, Frei Itaparica e as primeiras academias repetiram motivos e formas do barroquismo ibérico e italiano." (Alfredo Bosi, História concisa da literatura brasileira, p. 39.)

29 "Entre a ordem e o caos: colonialismo, escravidão e barroco no Brasil", Pindorama revisitada, p. 46.
} 
É também em função do caráter essencialmente dramático, no sentido próprio do termo, que a obra corneliana apresenta afinidades com essa arte tão marcadamente teatral e cenográfica ${ }^{30}$. Vander Melo Miranda centrou seu estudo de A menina morta na questão da encenação, das atitudes teatrais e do que ele denomina histrionismo dos personagens. Expressão tomada a Cornélio Penna - "a insuportável comédia" - faz o título desse trabalho. Um levantamento que tivesse o propósito de reunir todos os termos ou expressões que, no último romance publicado por Cornélio Penna, pertencem de algum modo ao campo do teatro e da representação teatral certamente os encontraria bastante numerosos. Sem levar essa tarefa a efeito, fiquemos com apenas alguns exemplos: "fingidas contorções de dor"; "lágrimas artísticas"; "pobre mascarada sem lágrimas"; "papel já muito ensaiado"; "inútil e cruel comédia”; "parecia estar no palco"; "o disfarce, a mascarada"; localizados todos apenas por uma busca relativamente superficial até a página 202 na edição da Artium de 521 páginas. Mas para quem conhece os romances anteriores não haveria surpresa alguma diante disso. Já em Fronteira, como foi visto, as alusões a máscaras e a representação eram assaz numerosas, ainda mais explícitas nas referências à encenação de Tia Emiliana. Mas não se trata sempre de um esforço consciente, pois o narrador-protagonista sente em determinados momentos que está representando sem que o desejasse e sem qualquer premeditação. Em Repouso não é diferente, e há uma passagem que talvez possa lançar alguma luz sobre esse aspecto da literatura corneliana. Trata-se de Dodôte e de uma divisão de sua personalidade que remonta à infância, quando começara a se encantar com a mentira que conscientemente uma vez pronunciara. Encontrara assim uma "solução lógica e simples (...) para tudo", até que "uma outra Dodôte surgira à sua frente e, por trás dela, a antiga Dodôte podia se ocultar em segurança, nos seus momentos de medo, de dúvida, de fuga, ou simplesmente de vida”. Um dia, porém, já moça, descobre que essa personagem criada ganhara vida própria, independente mesmo daquela que a criara.

Todas as alusões a gestos maquinais, a marionetes, fantoches e autômatos, a ações realizadas a despeito mesmo da vontade do sujeito parecem de algum modo relacionadas a essas máscaras criadas pelos indivíduos com o fim de se esconderem e se protegerem do outro, mas que acabam se tornando independentes deles, incapazes assim de controlar essas figuras artificiais. Com isso, invertem-se os papéis e aquele que

\footnotetext{
30 “This supreme art of theatrical decoration..." (E. H. Gombrich, The story of art, p. 437.)
} 
controlava o boneco sente-se controlado por ele, o titereiro vira títere. Por isso, trata-se de uma triste ou insuportável comédia. O oxímoro - pelo menos se compreendermos o termo comédia no sentido de representação cômica, e não do modo como Dante e depois Balzac o utilizam - remete àquela situação paradoxal e desumana. A presença quase obsessiva desses motivos alusivos à mentira e à encenação deve-se em primeiro lugar ao "verdadeiro horror" que o escritor dizia ter "de viver artificialmente, de criar sem sentir um personagem, e depois ficar prisioneiro dele, e ter de tomar atitudes literárias, de viver literariamente", como se expressou no depoimento a Ledo Ivo, conforme trecho citado no primeiro capítulo deste trabalho. Num segundo momento, porém, deve-se ao sentimento de que isso se tornava tão mais constringente na medida mesma em que a sociedade e a civilização mais se desenvolviam. Sem deixar de ser característico da sociedade e do tempo que Cornélio Penna busca representar, o fato é que em seu próprio tempo a utilização da máscara social torna-se praticamente inescapável.

Sem propriamente figurar o contemporâneo em seus romances, traços como o sentimento dos personagens de viverem como marionetes e de agirem maquinalmente não deixam de possibilitar o estabelecimento de um diálogo com um tempo marcado, por um lado, pelas linhas de produção industrial em série, em que o homem se tornava quase uma extensão da máquina, que tudo parecia comandar, e por outro, pelo envio de soldados aos campos de batalha para morrerem anônimos, apenas um número a mais nas assustadoras estatísticas das baixas, depois de terem obedecido cegamente a ordens superiores $^{31}$. Dizer que o Brasil não conhecia a rigor nenhuma das duas situações nos primeiros decênios do século XX não parece suficiente para se afirmar o anacronismo de um tal diálogo. Em 1936 o cinema já mostrava o primeiro estado de coisas no genial Tempos modernos, de Charles Chaplin, e as imagens da guerra também podiam ser vistas na grande tela não somente nos longa-metragens como em documentários sobre as guerras que tomavam conta do globo. Tendo Cornélio Penna vivido a maior parte de

\footnotetext{
${ }^{31}$ Ao tratar das guerras do século XX, Hobsbawn alude à "nova impessoalidade da guerra, que tornava o matar e estropiar uma conseqüência remota de apertar um botão ou virar uma alavanca." E prossegue: "A tecnologia tornava suas vítimas invisíveis, como não podiam fazer as pessoas evisceradas por baionetas ou vistas pelas miras de armas de fogo. Diante dos canhões permanentemente fixos da Frente Ocidental estavam não homens, mas estatísticas - nem mesmo estatísticas reais, mas hipotéticas, ..." (Era dos extremos, p. 57) Adorno, por sua vez, mostrou os estreitos vínculos existentes entre as máquinas modernas e a violência fascista: "A tecnificação torna, entrementes, precisos e rudes os gestos, e com isso os homens. Ela expulsa das maneiras toda hesitação, toda ponderação, toda civilidade, subordinando-as às exigências intransigentes e como que a-históricas das coisas. [...] Nos movimentos que as máquinas exigem daqueles que delas se servem localizam-se já a violência, os espancamentos, a incessante progressão aos solavancos das brutalidades fascistas." (Minima moralia, p. 33)
} 
sua vida em São Paulo e no Rio de Janeiro, é pouco provável, em que pese a sua fixação pelo passado, que ele próprio não tenha visto uns e outros. Ainda que fosse esse o caso, não teria como não ouvir comentários e participar de conversas sobre esses filmes e sobre o assunto de que tratavam, bem como de ler jornais e revistas, ele que era jornalista, que abordavam com destaque esses temas tão candentes ${ }^{32}$.

O que os romances indiciam é a vida que se tornava um palco e os homens, atores à própria revelia. $\mathrm{O}$ que seria uma defesa da individualidade volta-se contra $\mathrm{o}$ indivíduo, que passa a ser constrangido pela norma social a nunca mostrar-se verdadeiramente. Como em "O espelho", de Machado de Assis, a máscara adere de tal modo ao rosto que nem o próprio sujeito consegue mais se ver sem ela ${ }^{33}$. E não sendo apenas uma, acaba por se dividir em tantas personalidades como são as suas máscaras, exacerbando suas fraturas e cisões. Sem poder ser plenamente aquilo que se é, na verdade incapaz mesmo de conhecer e reconhecer o seu ser verdadeiro, o homem sentese cada vez mais insatisfeito e descontente. O papel da cultura e da civilização nesse estado de coisas foi explicitado por Freud em 1929/1930, em "O mal-estar na civilização": "Não é fácil entender como pode ser possível privar de satisfação um instinto [uma pulsão]. Não se faz isso impunemente.”; “A liberdade do indivíduo não constitui um dom da civilização. Ela foi maior antes da existência de qualquer civilização, .... ${ }^{34}$. Com o desenvolvimento cada vez mais acentuado da civilização ocidental e com o recrudescimento da repressão ou do recalque das pulsões, alarga-se o caminho para a doença. O próprio Freud mostrou, contudo, como é tênue a fronteira entre a normalidade e a patologia, de modo que aqueles que não parecem doentes não deixam de apresentar sintomas, nas mais diversas gradações, muito semelhantes aos que afetam os portadores de fato de neuroses ou psicoses. E nesses casos falar em cura é no mínimo um grande equívoco. Sendo o desamparo uma condição estrutural especialmente para o sujeito que vive na sociedade moderna, é possível somente aprender a conviver com ele ${ }^{35}$. Questão de sobrevivência no exato sentido do termo, há

\footnotetext{
${ }^{32}$ No acervo do escritor-pintor na Fundação Casa de Rui Barbosa, há inclusive uma charge sobre as relações entre a França e a Alemanha no período entre-guerras.

${ }^{33}$ Alfredo Bosi, História concisa da literatura brasileira, $3^{\text {a }}$ ed., São Paulo, Cultrix, 1990, pp. 197-8 e 203.

${ }^{34}$ P. 157 e 155 , respectivamente.

35 "Assim, é no contexto da cultura que o mal-estar do sujeito se impõe como estrutural, onde as oposições e os impasses entre a pulsão e a cultura atingem o seu cume. Com isso, Freud pôde destacar a posição estratégica do conceito de desamparo no psiquismo, indicando que face ao desamparo do sujeito na cultura não existe cura possível, mas somente a perspectiva de constituir um estilo subjetivo que seja capaz de lidar com os conflitos insuperáveis." (Joel Birman, Estilo de modernidade em psicanálise, p. 12.) "Enunciar que a experiência psicanalítica pretende ser a condição de possibilidade para que o sujeito
} 
sempre os que acabam por sucumbir, caso de Nico Horta e Urbano, ou os que enlouquecem, como a narrador-protagonista de Fronteira ou Dona Mariana.

Nessa tentativa de obter gradativamente uma maior aproximação do universo corneliano, por meio da escolha de alguns de seus elementos fundamentais, seja de caráter mais propriamente formal ou temático, e do estabelecimento de algum tipo de relação entre eles e diferentes aspectos da história pessoal do escritor ou da história em sentido mais amplo, ou ainda da própria história da arte, é preciso recorrer a outro importante movimento artístico de que também parece haver ressonâncias nos romances cornelianos, que não foram exatamente contemporâneos dele, mas escritos apenas poucas décadas depois de seu apogeu. Irene Jeanete Simões já chamou a atenção para o fato de que os jogos de luz e sombra presentes em Cornélio "lembram a atmosfera dos filmes expressionistas alemães" ${ }^{, 36}$, bem como detectou a presença em sua obra de outros elementos característicos da arte expressionista ${ }^{37}$. Embora a rigor não se possa caracterizar a obra pictórica ou a literária produzidas por Cornélio Penna como expressionistas, é preciso reconhecer que são muitas as coincidências. Com relação à pintura corneliana, Alexandre Eulálio vai aproximá-la, dentre muitas outras produções tão diversas, da "gráfica de Aubrey Beardsley", sem deixar contudo de acrescentar "que na obra de Penna vai sofrer inesperada metamorfose", tendo ressaltado de antemão "toda a singularidade dele", que ainda assim "participa de modo irreversível do ambiente cultural em que evoluiu" ${ }^{38}$. Embora não seja propriamente expressionista, a obra do artista inglês parece de algum modo parte de um amplo contexto em que se inclui o Expressionismo e que, como sempre, compreende tantas e tão diferentes facetas e artistas muitas vezes tão distintos, a despeito de algumas similaridades, que parece temerária - e talvez o seja mesmo - qualquer tentativa de classificação. De todo modo, Beardsley pertenceria ao que ficou conhecido como Art Nouveau e realizou diversos

possa construir um estilo para a sua existência, implica formular e reconhecer, como o seu corolário, que o ideal de cura em psicanálise fracassou, de fato e de direito, como hipótese teórica e clínica de trabalho. Esse ideal estava presente nos primórdios da história da psicanálise, de forma irrefutável, não obstante a astúcia retórica da crítica freudiana, precoce ao discurso da medicina e à enunciação correlata da originalidade do saber psicanalítico.” (p. 43.) V. também neste trabalho: cap.2, nota 25.

${ }^{36}$ Oficina de artista: a linguagem dos romances de Cornélio Penna, p. 31-2. A autora também afirma ser Cornélio Penna um "escritor expressionista". Para Maria Consuelo de Pádua Albergaria, os romances cornelianos não são a rigor expressionistas, mas "os traços expressionistas de deformação e recorte da realidade facilmente observáveis em sua pintura se encontram refletidos em sua literatura; estão presentes, mas não são exclusivos." (O espaço da loucura em Minas Gerais, p. 52.)

${ }^{37}$ Id., ibid., p. 33 e 47, dentre outras.

38 "Os dois mundos de Cornélio Penna", p. 456 e 454, respectivamente. 
trabalhos em bico-de-pena que devem ter sido vistos e admirados pelo Cornélio-pintor, e que alguns trabalhos seus não deixam de evocar. Outro artista com que a pintura corneliana apresenta pontos de contato é Edvard Munch, especialmente no que se refere à sua obra tão conhecida e reproduzida, "O grito". Munch teria exercido forte influência sobre os artistas alemães que fundaram a revista Die Brücke (A ponte), em 1905, referência quase imediata quando se pensa na arte expressionista. Uma descrição seguida de uma interpretação do quadro talvez nos ajude a pensar no que pode ser aproximado não apenas da pintura realizada por Cornélio Penna como de sua literatura:

Edvard Much, em seu quadro $O$ grito, expressa o total desespero; tudo na pintura reforça o desespero. A figura humana não possui substância, contorce-se e gesticula sob a pressão de suas emoções. As formas sinuosas do céu e da água, e a forte diagonal da ponte, tudo conduz o olhar para a boca que se abre num grito. Embora existam outras pessoas na ponte, há uma atmosfera de aterrador isolamento. O grito mostra que não existe fuga possível do ser, somente a sua dor insuportável. No quadro, não há alívio para o olhar, nenhuma parte do fundo que não seja agitada. A ênfase sobre linhas fortes e ritmos vigorosos, e a agitação na manipulação da tinta, tudo torna visível a emoção do artista. Munch, um norueguês obcecado com a morte, mostra uma condição que parece pior do que ela. ${ }^{39}$

Já fiz alusão ao desespero, à dor extrema, ao isolamento irremediável dos homens figurados na pintura realizada por Cornélio Penna. Toda a expressão desse desespero, dessa dor e dessa solidão, que no quadro de Munch se materializa em ondas que se espraiam por tudo o que contorna a boca desmesuradamente aberta daquele que grita, em Cornélio ora concentra-se nos corpos nus seccionados internamente por linhas contínuas, ora em figuras longilíneas marcados por angulosidades e contorções, ora nos gestos enfáticos e teatrais, ora ainda no pano de fundo negro ou nas cores sombrias com que pinta personagens e seus contornos, e em muitos casos na ausência mesma de qualquer contorno ou segundo plano.

Parece também pertinente associar aquela descrição/interpretação do quadro do norueguês aos romances cornelianos. A atmosfera de isolamento, a impossibilidade de fuga do ser, a dor insuportável, o obsessão da morte, tudo isso participa estreitamente da

\footnotetext{
${ }^{39}$ Rosemary Lambert, $A$ arte do século XX, História da arte da Universidade de Cambridge, p. 14.
} 
obra literária de Cornélio Penna. E se buscarmos observações que procuram caracterizar a arte expressionista, as "coincidências" parecerão ainda mais notáveis:

O traço comum neles [os artistas expressionistas], que de início não se conheceu, é uma tendência subjetiva pronunciada de projetar-se no quadro, identificar-se com o objeto. É uma projeção idêntica ao processo da empatia (Einfühlung). O quadro reflete as emoções e a participação psíquica do artista. Para eles só conta 'a expressão', desprezada qualquer lei estética ou técnica. ${ }^{40}$

Ou ainda:

A crença de que através da arte o artista podia transmitir diretamente uma espécie de sentimento interior - emocional ou espiritual - era uma idéia corrente nos círculos artísticos e intelectuais alemães do início do século XX. Vimos como um revivescimento da filosofia romântica oitocentista, o legado da Kulturkritik e os escritos de Nietzsche já haviam estimulado os artistas a buscas "novas liberdades", a livrar-se das restrições civilizadas e das convenções acadêmicas, e a de alguma forma expressar-se mais livremente; essas idéias são fundamentais para o que chamamos de arte "expressionista" alemã.

O termo 'expressionismo' foi usado com diferentes ênfases na história da arte moderna. Como rótulo estilístico, ele foi usado muitas vezes retrospectivamente para denotar, e implicitamente explicar, uma qualidade de distorção e exagero das formas encontradas na obra de qualquer artista do período. $^{41}$

Vimos anteriormente como Cornélio Penna manifestava a recusa a seguir "qualquer lei estética ou técnica", para retomar as palavras de Mário Pedrosa sobre os expressionistas, tomando partido de uma posição muito próxima do processo da "empatia" assim como do "expressar-se mais livremente", livre das "restrições civilizadas e das convenções acadêmicas”, para falarmos com Gill Perry. A expressão da subjetividade, do sentimento interior, se não se pretende direta, é inequívoca em seus livros, e o mundo que circunda os personagens é quase sempre projeção da interioridade deles, muito embora, como também foi visto, o contrário também seja verdadeiro.

\footnotetext{
${ }^{40}$ Mário Pedrosa, "Panorama da pintura moderna", Modernidade cá e lá, p. 155.

${ }^{41}$ Gill Perry, "O primitivismo e o 'moderno' ", Primitivsmo, Cubismo, Abstração: começo do século XX, p. 63.
} 
Finalmente, as distorções e o exagero também comparecem com freqüência nos romances, não só em relação aos personagens como em toda a realidade figurada, nos sentimentos superdimensionados e hiperbólicos, na mascarada, nos automatismos, nas edificações que ganham vida e se voltam contra o sujeito e na fúria dos elementos, igualmente personificados, que se abatem sobre as casas e sobre os homens, nos esgares e no riso alucinado da loucura.

A menção ao fato de aquelas características terem sido utilizadas para rotular as obras de artistas do mesmo período não significa que elas não sejam também significativas nas obras do grupo de artistas que Gill Perry se propõe a estudar, os expressionistas alemães, ao tempo em que previne aquele que se propõe a compreender a produção artística de determinado período contra o impulso inicial de tudo rotular e de colocar num mesmo compartimento obras que apresentem um ou dois aspectos que parecem comuns, sem levar em conta a individualidade do artista, o contexto em que surgiram e a história de sua produção. Para dizer uma vez mais: não acredito que seja adequado denominar a literatura corneliana de expressionista, nem que haja qualquer ganho em substituir por este o rótulo intimista. O que pode ser dito é que ela contém traços expressionistas, não só pelo conhecimento que Cornélio pode ter tido da "vaga expressionista" (Mário Pedrosa), pelas afinidades de que ele próprio poderia ter consciência, como pelo momento muito próximo das duas produções. E se levarmos em conta o atraso da periferia em relação ao centro, é bem provável que o contexto da Europa do início do século se assemelhe menos ao contexto brasileiro do mesmo período do que àquele dos anos 30 e 40. Por isso, as referências a Freud não são também gratuitas. É exatamente entre o final do século XIX e nas primeiras décadas do XX que o criador da psicanálise faz suas grandes descobertas. Mesmo tendo sido os surrealistas aqueles que mais beberam em Freud, não creio que não se possam estabelecer algumas relações entre ele e a arte expressionista. Do mesmo modo, em Cornélio - tenha ou não o escritor conhecido superficialmente ou mais a fundo a obra freudiana - encontramos mais de um ponto de contato entre seus romances e a teoria freudiana.

No capítulo dedicado à leitura de Fronteira, apenas mencionei a coincidência entre uma passagem do romance e um episódio contado por Freud numa nota de rodapé de um dos mais intrigantes e instigantes textos por ele escritos, "O estranho", de 1919. Em Fronteira, o narrador-protagonista vê a imagem de um vulto estranho cujo olhar encontra o seu, ambos se fitam com estranheza, até que percebe tratar-se de um espelho 
em que se refletia a própria imagem. Com Freud, acontecera quase o mesmo, com a diferença de que estava no carro-leito de um trem. Um solavanco mais brusco fez com que a porta da toalete abrisse, e no mesmo instante pareceu-lhe que um senhor de idade por ali entrava. Ao levantar-se para fazer ver ao outro que se enganara de compartimento, deu-se conta de que não era senão a sua imagem refletida no espelho. Freud ainda acrescenta ao relato a antipatia que imediatamente sentira por aquele estranho intruso.

As coincidências contudo não terminam aí. O ponto de partida para a abordagem por Freud do fenômeno do "estranho" ou do "sinistro", "aquela categoria do assustador que remete ao que é conhecido, de velho, e há muito familiar", é um conto de E. T. A. Hoffmann que tem como título "O homem da areia", centrado na paixão de um personagem por um autômato construído na forma de uma bela moça, até ser levado ao enlouquecimento e à morte. Uma vez mais, reconheçam-se aí elementos que estão presentes em toda a literatura corneliana e não apenas no primeiro romance: as ações maquinais, os autômatos e marionetes, o sentimento da incapacidade de controle sobre o corpo e de que um outro parece dirigir os próprios movimentos, a loucura e a morte. A diferença, assim, é que em Cornélio não é o outro que é descoberto como autômato, mas o próprio sujeito se percebe como um. Mas é essa uma diferença relacionada apenas ao conto de Hoffmann e de maneira alguma a Freud: "Para a psicanálise, o estrangeiro é o eu." 42 Por isso, o paradoxo do estranho que é familiar. Por isso também, as diversas menções ao demônio e ao demoníaco nesse e em outros trabalhos de Freud: é como se uma legião de demônios se tivesse instalado dentro de nós, mas aqui sem possibilidade de os exorcizarmos de todo.

Em Fronteira, sem empreender um levantamento muito rigoroso, encontrei 25 páginas, espalhadas do começo ao fim do romance, das 162 que ele ocupa na edição da Artium, que trazem o motivo do estranhamento ou do desconhecimento de si mesmo e do outro, do sentir-se um outro, do ver-se a si próprio ou ao outro como estranho ou estrangeiro. Alguns desses momentos são claramente associados à proximidade da loucura: “... e as mãos soltas em movimentos inconscientes, senti que estava prestes a perder meu equilíbrio, tão penosamente mantido.” (p. 117); “... e vi-me ao desamparo, [...] sem forças para defender-me da insuportável sensação de exílio que me dava a

\footnotetext{
${ }^{42}$ Neusa Santos Souza, "O estrangeiro: nossa condição”, p. 155.
} 
brusca mudança de cenário que se operava em torno de mim. // De novo, senti que se aproximava rapidamente a fronteira da loucura, ...” (p. 147)

Levantamentos semelhantes em relação aos outros romances talvez mostrassem uma menor incidência do motivo do estranhamento sem absolutamente se ausentar de todo. Fiquemos com pelo menos um exemplo de cada romance. Em Nico Horta: "Sentia [Nico Horta] apenas que tinha um hóspede obscuro e imposto, dentro de si, um invasor invencível, que se movia lentamente no silêncio e no abandono da vida.” (p. 212) Em Repouso: "Veio então ao seu encontro [de Urbano], saída de onde a relegara a sua violência de há pouco, de novo sorridente e calma, a cabeça a oscilar levemente, como se aprovasse sempre, a outra criatura que usurpara o seu lugar, o lugar daquele que já fugia sem deixar vestígios, ..." (p. 188) E, finalmente, n' A menina morta: "Seu coração [de Carlota] batia agora tão lentamente que o sangue parecia querer parar em suas veias e era agora ela própria a estranha, alguém que não conhecia que foi para o seu leito e nele se sentou." (p. 293)

A maior freqüência - pelo menos na aparência - desse motivo no primeiro romance publicado pelo escritor talvez se justifique por ser esse o tema central, mas sua presença quase obsessiva em toda a obra é índice da força da loucura em seu imaginário. A Ledo Ivo, ele revelara: "Um dia li Quincas Borba e fiquei trêmulo, comovidíssimo, certo de que era louco também." $" 43$ Talvez o motivo da loucura possa ser pensado em pelo menos dois níveis de realidade ${ }^{44}$, o que seria extensivo a outros motivos igualmente fundamentais, boa parte deles estreitamente ligados à "fronteira da razão", como o desamparo e o estranhamento de si e do outro. Um primeiro nível remeteria ao histórico, às circunstâncias sócio-econômicas e culturais, ao contexto em que a loucura se manifesta. Nesse sentido temporal, ela seria motivada sobretudo pelas contradições advindas da existência de dois mundos, não no sentido em que Alexandre Eulálio emprega a expressão, mas no da coexistência de modernidade e tradição, dos avanços em meio ao atraso, das transformações constantes ao lado das permanências

\footnotetext{
${ }^{43}$ Romances completos, p. LVII. A grande admiração que tinha por Machado de Assis, como não podia deixar de ser, não seria inteiramente pacífica - "Que gelado pessimismo! zombeteiro e mau ele vai suavemente nos convencendo de que talvez não exista aquilo que mais queremos que exista... e não nos convence, deixa-nos a dúvida, passando para outra crença, com a maior naturalidade." ("Machado de Assis", 1938) -, mas pode-se ter uma idéia da sua dimensão por um depoimento de 1955: "Quanto aos [escritores] nacionais, Cornélio Penna diz que, se acaso fosse escrever a literatura do Brasil, começaria assim: 'No começo era o nada; depois apareceu Machado de Assis; depois... o nada outra vez.' " (Renard Perez, "Cornélio Penna" - Escritores Brasileiros Contemporâneos.)

44 "Différents niveaux de réalité, cela existe aussi en littérature; plus encore, la littérature repose précisément sur la distinction de divers niveaux de réalité, et serait impensable sans cette distinction." (Ítalo Calvino, "Les niveaux de la réalité em littérature", La machine littérature, 1984.)
} 
mais arraigadas, da democracia em meio a todo tipo de autoritarismos, do que há de mais civilizado ao lado da barbárie mais selvagem. Mas não se veja nesses pares constituídos de elementos opostos a menor sombra de um maniqueísmo que agrupasse os primeiros termos num campo positivo e os outros, num negativo. A questão é bem mais complexa. O mais civilizado ou aparentemente civilizado é muitas vezes - se não quase sempre - o responsável pelos atos mais bárbaros, assim como muito do atraso ou do supostamente atrasado em geral - como as práticas mágicas, as "crendices" e "superstições" - é sobretudo um meio de resistência ${ }^{45}$ dos excluídos e muitas vezes a única defesa de que se podem valer contra a opressão da sociedade civilizada e de seus agentes políticos, administrativos e policiais. Nesse nível, teríamos com toda a sua força uma realidade especificamente brasileira ${ }^{46}$, e nele o caminho percorrido por Cornélio Penna, na seqüência dos romances, tenha ou não sido pensado nesses termos, é inteiramente coerente e compreensível, e quase se poderia dizer inevitável: não seria a escravidão ao mesmo tempo a razão mais importante e o exemplo mais cristalino de todos as nossas abissais disparidades e profundos contrastes? Não seria a produção agrícola em grande escala por meio do trabalho escravo um dos momentos privilegiados, se não o melhor, para se perceber em toda a sua crueza a união estreita entre civilização e barbárie?

\footnotetext{
45 Leia-se aqui "resistência" não num sentido redutor, que opõe opressor e oprimido de maneira maniqueísta, criticado por José Guilherme Cantor Magnani, em Festa no pedaço (p. 33), mas num sentido muito mais complexo, em que resistir à opressão é apenas parte do significado da cultura "popular" e pode se dar de muitas formas, inclusive pela utilização das próprias "armas" do opressor e do aproveitamento de elementos os mais diversos, procedentes das mais diversas fontes, naquilo que Certeau denominou "caça-não-autorizada", incorporando-os à própria cultura, modificados e desviados de suas funções e propósitos originais, como no détournement proposto por Guy Debord. (Devo a Elena Pajaro Peres a problematização da palavra "resistência", a indicação do livro de Magnani e, ainda mais importante, um diálogo de longa data, extremamente profícuo e esclarecedor, sobre as idéias de Certeau e Debord, também compartilhado por Nelson Aprobato Filho.)

46 “Uma superação da doutrina democrática só será efetivamente possível, entre nós, quando tenha sido vencida a antítese liberalismo-caudilhismo. // Essa vitória nunca de consumará enquanto não se liquidem, por sua vez, os fundamentos personalistas e, por menos que o pareçam, aristocráticos, onde ainda se assenta nossa vida social. Se o processo revolucionário a que vamos assistindo, e cujas etapas mais importantes foram sugeridas nestas páginas, tem um significado claro, será este o da dissolução lenta, posto que irrevogável, das sobrevivências arcaicas, que o nosso estatuto de país independente até hoje não conseguiu extirpar. Em palavras mais precisas, somente através de um processo semelhante teremos finalmente revogada a velha ordem colonial e patriarcal, com todas as conseqüências morais, sociais e políticas que ela acarretou e continua a acarretar. // A forma visível dessa revolução não será, talvez, a das convulsões catastróficas, que procuram transformar de um mortal golpe, e segundo preceitos de antemão formulados, os valores longamente estabelecidos. É possível que algumas das suas fases culminantes já tenham sido ultrapassadas, sem que possamos avaliar desde já sua importância transcendente. Estaríamos vivendo assim entre dois mundos: um definitivamente morto e outro que luta por vir à luz." (Raízes do Brasil, p. 134-5, grifo meu.) É de se pensar se muito desse estado de coisas assim descrito por Sérgio Buarque de Holanda não seria ainda uma realidade no Brasil do século XXI.
} 
Em outro nível de realidade, num sentido por assim dizer atemporal ou intemporal, teríamos a loucura como inerente ao homem e à condição humana, como já mencionei, do mesmo modo que o desconhecimento, a ausência de sentido para a vida, o inescapável da morte, a dor e o sofrimento, e assim por diante ${ }^{47}$. Aqui, poderíamos falar não tanto em "desterrados em nossa própria terra", na admirável expressão buarqueana, como em "desterrados na Terra", e seria possível associar a literatura corneliana a diversos escritores e artistas, não apenas os românticos e simbolistas imediatamente lembrados diante de uma expressão como essa, mas aqueles dos mais diversos tempos e lugares, que de maneiras muitas vezes tão diferentes figuraram essa mesma condição. É claro que este nível não se separa inteiramente do anterior senão por uma questão de ênfase, destacando-se nele mais o que é próprio do indivíduo do que o que advém de seu contexto histórico e social. Um como outro nível encontram-se em todos os quatro romances cornelianos, mas parece certo que este segundo predomina no primeiro romance, Fronteira, e talvez continue preponderante nos dois romances seguintes, enquanto o primeiro nível acaba por predominar no último, A menina morta. Contudo, parece-me que, num como noutro caso, a loucura não é vista senão em toda a sua complexidade, em seu lado negativo como no que pode ter de positividade. Se a loucura de dona Mariana, em A menina morta, e a do narrador-protagonista de Fronteira participam ambas, ainda que em diferentes graus, do desamparo propiciado tanto pelo estar no mundo como pela vivência em um meio social hostil, essa loucura não é apenas exclusão como também auto-exclusão, não é somente derrota, mas refúgio e resistência, a maneira encontrada para ao menos preservar a vida e de algum modo se furtar às coerções sociais.

Todas essas considerações precisam ser vistas com muito cuidado por serem o seu tanto abstratas e esquemáticas. Para dizer uma vez mais: as fraturas do sujeito, seu desamparo e sua loucura têm muitas motivações, e nem é possível conhecê-las todas

\footnotetext{
${ }^{47}$ Claro está que são muito diferentes as maneiras como cada indivíduo e cada grupo social lidam com essas questões vitais. Algumas culturas conseguem conviver muito bem com a inevitabilidade da morte, geralmente em função da crença em algum tipo de sobrevivência posterior, e, muitas vezes por meio de explicações mágicas e míticas, têm resposta para quase tudo. Contudo, o próprio fato de precisarem lançar mão desses meios é indício de que o problema da morte e do desconhecimento não deixa de ser colocado mesmo para os povos mais "primitivos". Na civilização ocidental mais desenvolvida, para apaziguar a angústia diante dessas questões, surgem as crenças mais inverossímeis, muitas vezes por parte dos que se acreditam os mais racionais e que lidam com a razão mais abstrata. Por outro lado, muitos dos que crêem agem com frequiência em total desacordo com aquilo em que acreditam, o que mostra como é frágil em geral essa fé.
} 
nem se pode separá-las de todo umas das outras a não ser abstraindo a realidade de sua existência. É assim que a sexualidade, que parece muitas vezes uma questão inteiramente pessoal, a despeito de sua universalidade, tem nos estudos freudianos a demonstração dos estreitos laços que a ligam à sociedade e às normas sociais, e por extensão às divisões do sujeito, aos seus desequilíbrios e perturbações, sejam ou não de caráter patológico $^{48}$, e à pulsão de morte ${ }^{49}$. É assim também em Cornélio Penna e não apenas em Fronteira como - embora de modo não tão explícito - nos demais romances. Nesse sentido, discordo inteiramente de Luiz Costa Lima, que vê a ausência da sexualidade nos três últimos romances. Ela está inequivocamente presente em Dois romances de Nico Horta: nas relações de dona Ana com o primeiro marido - "Pela languidez de seus movimentos, pelo quebrado mórbido de suas bocas, podia-se ver bem o cansaço dos gestos de amor que tinham feito, da agitação da noite que tinha passado." (p. 17); no desejo que ele e o irmão nutrem por Maria Vitória e depois, na atração que Nico sente em relação a Rosa; e principalmente na narração da primeira noite de núpcias de Nico e Maria Vitória: “Toda aquela imensa vontade de viver e de fecundar se concentrava em seu coração e o mormaço vibrante e fecundo dos campos, erguendose e perdendo o contacto com a terra, confundia-se com o seu desejo..." (p. 209). Aparece também em Repouso, num dos capítulos iniciais, nas sugestões de um homem que também olhara para Dodôte e também a fitara com desejo, e depois em algumas alusões às relações sexuais depois do casamento: "Agora que conhecera

48 “... não é cientificamente viável traçar uma linha de demarcação entre o que é psiquicamente normal e anormal, de maneira que esta distinção, apesar de sua importância prática, possui apenas um valor convencional." ("Esboço de psicanálise”, p. 237.)

49 Não há espaço aqui para a discussão de problema tão complicado como o da relação entre eros e tânatos em Freud, ou entre as pulsões de vida e as de morte, o que demandaria estender a reflexão ao dualismo freudiano e às diferentes formulações que ele recebeu, ao longo do tempo, do fundador da psicanálise. Em todo caso, mesmo uma afirmação como a de Luiz Alfredo Garcia-Roza de que "não há pulsão sexual" [...] ... mas pulsão, pura e simplesmente" não significa a diminuição do papel da sexualidade e a recusa das ligações estreitas entre ela e a morte no pensamento de Freud. ( $O$ mal radical em Freud, p. 144.) Depois de Freud, ninguém mais que Bataille parece ter aproximado tanto a sexualidade e a morte: "Há, na passagem da atitude normal à do desejo, uma fascinação fundamental da morte. O que o erotismo implica é sempre uma dissolução das formas constituídas, ou seja, repetindo, da formas da vida social, regular, que fundam a ordem descontínua das individualidades definidas que somos." (O erotismo, p. 18) "Se virmos nas proibições essenciais a recusa que opõe o ser à natureza, encarada como desperdício de energia viva e como orgia de destruição, não podemos continuar a estabelecer diferenças entre a morte e a sexualidade. Sexualidade e morte são apenas os momentos culminantes da festa que a natureza celebra com a inesgotável multidão de seres. Uma e outra têm o sentido do desperdício ilimitado a que a natureza procede contra o desejo de durar que é próprio de cada ser." (p. 54) "Mas a superabundância de energia não deixa por isso de ser a base do início da actividade dos órgãos sexuais. E, tal como para os seres mais simples, esta superabundância leva à morte. // Não leva directamente. Regra geral, o indivíduo sexuado sobrevive à superabundância e mesmo aos excessos a que o conduz a superabundância. A crise sexual só leva à morte em raríssimos casos que têm, importa dizê-lo, um significado impressionante. Mas, para a nossa imaginação, a prostração consecutiva do paroxismo final é tão impressionante que o consideramos uma 'pequena morte' ’. (p. 87) 
verdadeiramente Urbano, que tivera inteira compreensão do corpo dele e do seu próprio, ...” (p. 201); “amor físico que não realizava o seu desejo intenso, nunca satisfeito, sempre dolorosamente iludido, de presença, de intimidade absoluta, de companhia total e de socorro...” (p. 242) E, finalmente, n' A menina morta, embora apenas insinuadas, as relações entre as escravas e o feitor "de dentro" e, pelo menos na minha leitura, as possíveis relações entre dona Mariana e Florêncio, sem contar o episódio do touro, de simbolismo claramente alusivo aos desejos e à sexualidade.

A impressão de ausência dessas temáticas nesses três romances talvez se deva ao contraste entre a presença realmente não muito freqüente e um tanto quanto discreta neles quando comparada com sua reiterada e marcante presença em Fronteira. Tentei mostrar quando da análise desse romance todo o caráter transgressivo da relação entre o narrador-protagonista e Maria Santa. Procurei também sublinhar o modo como o sexo se aproxima ali da morte e como o pensamento de Bataille pode ajudar a compreender a intrincada e complexa mistura entre a sexualidade e o sagrado. Se, como foi dito então, a cena em que o narrador descobre o corpo nu de Maria Santa e depois as sugestões de que não recuara do ato sexual pareciam dar à narrativa um caráter quase blasfemo, a história do Catolicismo, ainda que vista de maneira superficial, nos mostra que aquela mistura - em que pese todo o esforço de separação e a repressão desencadeada pela Igreja para manter o erotismo fora da esfera sacra - não lhe é absolutamente desconhecida. Fiquemos com dois exemplos.

Na Capela Cornaro, na Igreja de Santa Maria della Vittoria, em Roma, encontrase um belíssimo conjunto escultórico, O Exxtase de Santa Teresa, de autoria do mais genial artista do barroco italiano, Gian Lorenzo Bernini. O motivo da obra: Santa Teresa d'Ávila, uma freira espanhola do século dezesseis e "uma das grandes santas da ContraReforma", havia narrado suas visões místicas e de uma delas "contara que um anjo lhe trespassara o coração com uma seta de ouro flamejante: 'A dor foi tão intensa que gritei; mas ao mesmo tempo, senti uma tão infinita doçura que desejei que a dor jamais acabasse. Não foi uma dor física, mas mental, embora afectasse também, de alguma maneira, o corpo. Foi a mais doce carícia da alma por Deus'." ${ }^{50}$ Esse motivo, que já contém em si muito de sensualidade e erotismo, foi trabalhado por Bernini de modo a enfatizá-los ainda mais. A sensualidade presente na cena figurada é assim comentada por Janson: "Bernini tornou esta experiência visionária tão sensualmente real como a de

\footnotetext{
${ }^{50}$ H. W. Janson, "O Barroco na Itália e na Alemanha", História da Arte - Panorama das Artes Plásticas e da Arquitectura da Pré-História à Actualidade, p. 487-8.
} 
Júpiter e Io de Corregio. Num contexto diferente, o anjo não se distinguiria de Cupido $^{51}$, e o êxtase da santa é manifestadamente físico." Não deixa de notar, contudo, o que há de visão essencialmente mística nas esculturas: "Mas as duas figuras, na sua nuvem flutuante, são iluminadas (por uma janela escondida em cima) de tal forma que parecem quase incorpóreas na sua brilhante alvura. $\mathrm{O}$ observador sente-as como visões." ${ }^{, 52} \mathrm{O}$ que Bernini então obtém com sua magnífica obra não é transformar um êxtase místico numa cena erótica e sensual, mas a radicalização das tensões entre o corpóreo e o incorpóreo, entre o sensual e o místico, entre o erótico e o sagrado, que de algum modo já estavam presentes no relato de Santa Teresa. A ambiência parece de fato etérea, mas a postura do corpo da santa - coberto por panejamentos esvoaçantes inacreditavelmente esculpidos em mármore - e sobretudo a expressão de seu rosto, realização magistral do escultor, são aqueles de uma mulher no ponto mais alto da excitação sexual. E no entanto o grupo foi projetado para a capela de uma igreja em Roma e envolve não apenas o grupo escultórico, mas toda uma cenografia verdadeiramente teatral, que inclui, como observa Janson, a entrada de luz natural por uma janela oculta, o que provoca um incrível efeito sobre o espectador ainda hoje, que dirá no século XVI em que foi realizada, quando devia despertar, nas palavras de Gombrich, "feelings of fervid exultation and mystic transport at which the artists of the Baroque were aiming"53.

O segundo exemplo é a poesia mística de San Juan de La Cruz. A proximidade do pensamento desse místico com a obra corneliana foi mencionada por mais de um crítico, mas ganha ênfase sobretudo com os estudos de Adonias Filho, como nota Haquira Osakabe:

... em Fronteira: loucura, pecado e santidade estão inapelavelmente juntos como condição da salvação. Difícil fica não reconhecer nessa formulação uma incorporação, mesmo que indireta, da mística de San Juan de La Cruz. Adonias Filho [...] assinala exatamente a doutrina de San Juan como a grande matriz explicativa do texto corneliano. Vejamos em que sentido. Para o doutor Místico, o encontro com Deus não é conquista nossa, é dom divino. O homem poderá e deverá dispor-se a esse encontro. Mas a união só se fará com a intervenção de

\footnotetext{
${ }^{51}$ André Chastel fala do "anjo em postura de Eros". (A Arte Italiana, p. 518.)

${ }^{5}$ Op. cit., p.487-8. V. também E. H. Gombrich, The story of art, p. 437-40, incluindo ótima reprodução de todo o conjunto escultórico e detalhe do rosto de Santa Teresa.

${ }^{53}$ Id. ibid., p. 438.
} 
Deus. A conjugação da noite ativa, aquela que depende do esforço humano, com a noite passiva, é que fará a união da alma com o esposo que é Deus. Daí que a mística de San Juan não se coadune com o quietismo, a contemplação estática. O congraçamento místico não se dá assim gratuitamente [...]. O trajeto dos romances cornelianos tem a ver com as sucessivas noites escuras e todas as personagens que atingem o entendimento mobilizam-se no tensionamento de um processo expiatório que chega à beira do extenuamento. [...] Mas no centro dos dramas há um processo intermitente de intervenção da graça que não se anuncia por acaso. Ainda mais: que acende, no homem que busca, com a chama de seu desejo a intensidade de um necessário sofrimento.

A associação da alma unida a Deus à mulher que se une ao esposo é o que permite ao poeta a criação de imagens de uma sensualidade muito próxima daquela expressa por Santa Teresa e figurada em mármore por Bernini:

Oh! chama de amor viva,

que ternamente feres

desta minha alma a mais profunda cela!

Tu já não és esquiva,

acaba já se queres;

deste tão doce encontro rompe a tela.

Oh! cautério suave!

oh! deliciosa chaga!, oh! mão branca, carícia delicada, que à vida eterna sabe, que toda culpa apaga!, matando, morte em vida é transformada.

$[\ldots]$

Quão manso e amoroso despertas em meu seio, onde secretamente só tu moras!; no aspirar saboroso, de bem e glória cheio, 
quão delicadamente me enamoras!

[Chama de amor viva]

[Canções da alma na íntima comunicação de união de amor de Deus]

Outros exemplos podem ser dados. Vejamos apenas uma estrofe do belo poema "Noite escura":

Em meu peito florido,

que inteiro só para ele se guardava,

quedou-se adormecido,

e eu o acariciava,

e eis que o leque de cedro perfumava. ${ }^{54}$

Não é obviamente casual o fato de ser São João da Cruz contemporâneo de Santa Teresa de Ávila, como de ter convivido com ela, tendo inclusive exercido por um período de cinco anos o cargo de "confessor e diretor espiritual do convento da Encarnação de Ávila, cuja superiora era Teresa de Jesus”. Era vinte e sete anos mais novo que ela e, mesmo que eu não conheça suficientemente a obra de ambos para falar em possíveis influências, é certo que o fato de compartilhar a mesma ambiência da Contra-Reforma, em que floresceu a arte barroca, tem grande papel nas semelhanças entre o relato das visões de Santa Teresa e a poesia de São João da Cruz.

Quanto a Cornélio Penna, antes de mais nada, é preciso dizer que a sexualidade aparece em sua obra, especialmente em Fronteira, de maneira inambígua. O que quer que haja de místico na relação entre Maria Santa e o narrador do diário é também de caráter inequivocamente sexual. Em relação a possíveis associações entre a literatura corneliana e os textos e poemas escritos pelos santos da Igreja, ainda que Cornélio possa ter lido uns e outros, o que é bem provável no caso de um católico praticante, parece-me prudente a posição de Haquira Osakabe ao expressar de modo concessivo a possibilidade de ter sido indireta a influência ou "incorporação" do pensamento de São João na literatura corneliana. Não há como não pensar também em alguma semelhança entre o contexto vivido pelos dois santos e aquele do escritor. Procurei mostrar no segundo capítulo as coincidências entre a Europa medieval e o Brasil do final do século

\footnotetext{
${ }^{54}$ São João da Cruz, Poesias completas.
} 
XIX e começo do XX, sem prejuízo obviamente das enormes diferenças. A presença de grandes tensões - existentes, na verdade, em qualquer tempo, mas que parecem em alguns momentos recrudescer de modo tal a serem vistas mesmo como insolúveis seria um desses pontos de contato entre tempos e lugares tão distantes. Quanto ao pecado e à graça, creio ser indispensável algum conhecimento teológico para a sua discussão, o que não é o meu caso. Porém, para dizer uma vez mais, se o escritor pretendeu mesmo centrar Fronteira e os outros romances nessas questões teológicas, eles acabam como que se rebelando e se recusando a permanecer dentro dos limites da fé. Independente, pois, da crença do leitor na existência do pecado ou da graça, o que ele pode encontrar nos quatro romances cornelianos são os conflitos, os desejos, as insuficiências, as frustrações, as esperanças ou desesperanças dos homens. O anelo de que a morte não seja o limite da existência humana não se destaca dos desejos de satisfação pulsional, que por um lado se aproximam da morte e por outro são pura afirmação da vida e parte do mesmo anseio por aquela continuidade buscada na crença e na religião.

Se há diferenças entre os romances na abordagem da sexualidade, como foi visto, a impressão que fica é a de que sempre prepondera o fracasso. Seja nas relações entre marido e mulher, seja naquelas que se dão fora do casamento, não se consegue nunca a satisfação plena e duradoura, ou porque ela é sempre fugaz, ou porque nunca permite de fato a fusão e a confusão total entre dois seres, que invariavelmente acabam por se sentirem estranhos um ao outro, ou ainda porque ela sofre toda a sorte de restrições e sanções do meio social e de instituições como a Igreja.

No terceiro capítulo fiz alusão à onipresença de quadros e retratos familiares na obra corneliana e a relação simultânea que eles mantêm com a arte e a memória. Poderia também ter dito que eles não surgem nunca como objetos isolados, destacados do ambiente das casas velhas guarnecidas com móveis e objetos que carregam igualmente os sinais da passagem do tempo e aqueles que neles imprimiram todas as gerações passadas, seres que parecem ainda habitá-las, a transitar feito espectros por meio de seu mobiliário antigo:

Alma de colecionador, vivendo no convívio dos objetos velhos, Cornélio Pena sabe traduzir, como ninguém entre nós, o sabor de beleza misturado ao de segredo, de degeneração e mistério, que torna uma arca antiga, uma caixinha-de-música, um leque, tão 
evocativos, repletos de sobrevivência humana assombrada. Se sente que os seus romances são obras de um antiquário apaixonado, que em cada objeto antigo vê nascer uns dedos, uns braços, uma vida, todo um passado vivo, que a seu modo e em seu mistério ainda manda sobre nós. 55

Observação de admirável argúcia crítica, ainda mais espantosa se Mário de Andrade não conhecia o modo como Cornélio vivia de fato como um antiquário ${ }^{56}$, ela se torna ainda mais certeira se pensada em relação aos dois romances que Cornélio iria ainda publicar, revelando que, à medida que passava o tempo, mais apegado se tornava o escritor a essa mobília e a esses objetos miúdos vindos de tempos remotos. Sirva de exemplo o capítulo de Repouso em que Dodôte, depois de casada, se muda para a casa da botica, que fora dos pais de Urbano (número 40). No limiar da porta do quarto, Dodôte insiste com Chica para que o deixe exatamente como no tempo da sogra, sua Tia Narcisa, a despeito dos apelos da ama para que dessem um "novo arranjo nessas coisas" sob o argumento de que não prestava "deixar assim mesmo como ela deixou, agora que está morta” (p. 198). Ao nele adentrar, todo aquele ambiente antigo traz a história do sofrimento da mãe de Urbano com sua partida para a cidade grande, a ausência de notícias mais freqüentes, as referências a uma outra moça, Maria do Carmo, e finalmente a notícia de seu casamento com ela no lugar de Dodôte, que lhe estava destinada. E de repente, em meio a essas lembranças, algo parece se mover no quarto. Era a cadeira de balanço, "feita toda de paus torneados, forrada de couro com o pelo manchado de branco muito gasto", que parecia ter se movido sozinha. E a impressão de Dodôte é de que "a antiga dona do quarto erguera-se dela naquele instante, ao pressentir a chegada da nova dona (...) e fugira em silêncio", até olhar novamente e dar-se conta de que "nada havia ali de sobrenatural". Já comentei a respeito mesmo dessa passagem as mudanças em relação aos dois primeiros romances, que poderiam ser resumidas nessa última frase. As sombras dos mortos, porém, não parecem exorcizadas, pois continuam a circular pelas casas antigas em meio aos velhos móveis quase como antes.

O mesmo que se disse dos quadros e retratos de família pode então talvez ser dito da literatura corneliana. Transitando entre a arte e a memória, eles trazem o passado

\footnotetext{
${ }^{55}$ Mário de Andrade, "Romances de um antiquário", O empalhador de passarinho, p. 128.

${ }^{56}$ Além da valiosa descrição de Ledo Ivo, alguns desses móveis e objetos antigos podem ser vistos na Fundação Casa de Rui Barbosa, no Arquivo-Museu de Literatura Brasileira, seja indiretamente em reproduções fotográficas, seja na contemplação direta, dentre outros, de duas caixinhas de música (que de diminutivo só tem o nome), de uma arca, uma cadeira de balanço, um móvel com espelho redondo para o barbear e o quadro da menina morta. Alguns desses objetos, como o quadro e a caixinha de música, são descritos nos romances do escritor.
} 
na medida mesma em que o recriam. Paradoxalmente, mergulham cada vez mais na direção do passado para melhor aludir às tensões do presente. As marcas deixadas pelas gerações passadas nos objetos antigos e antiquados parecem tão indeléveis como aquelas que a história gravou na consciência e no imaginário dos homens que os herdaram. Inevitável pensar no Drummond de "Os bens e o sangue". A diferença é que o itabirano de fato e de direito o tempo todo insiste na recusa dessa herança, embora reconheça não só a inutilidade desse gesto como o efeito contrário que provoca ${ }^{57}$, enquanto o itabirano por escolha ou fatalidade parece comprazer-se nela. Talvez seja essa diferença o motivo por que Drummond em carta a Cornélio manifeste a respeito de sua obra (que se resumia aos dois primeiros livros até então publicados pelo escritor), ao lado de admiração e simpatia, "certa perplexidade também, diante da sua interpretação do mistério de Itabira, [...] que me perturba como esse próprio mistério" e a "impressão de angústia e sufocação, perfeitamente desagradável"58. Como essa ambivalência, contudo, parece não ser exclusiva de Drummond, mas de muitos leitores da obra de Cornélio Penna, pode-se pensar que ela seja fruto em alguma medida de posição ambígua semelhante à do poeta. O desconforto, o mal-estar e o irrespirável da atmosfera adviriam assim de que muito do que se encontra nos romances cornelianos ecoa dentro de nós de modo estranhamente familiar. O que gostaríamos estivesse morto e enterrado nos ronda como fantasmas ainda que não mais acreditemos em avantesmas e assombrações.

Dos diversos Cornélios, contudo, há um cuja existência talvez não suspeitássemos não fosse a parte pictórica da obra que deixou. Composta de charges, caricaturas e sátiras políticas e de costumes, alguns dos trabalhos presentes em seu acervo - talvez apenas uma pequena parte de tudo o que realizou nessa área - poderiam figurar tranqüilamente ao lado dos deliciosos e divertidos exemplos recolhidos por Elias Thomé Saliba em seu estudo sobre o riso entre o final do dezenove e a primeira metade do século XX. Ainda que concordemos com Alexandre Eulálio, para quem, a despeito do "espírito de observação e talento humorístico", essa produção permanece "alheia ao interesse íntimo do criador", parece inegável o senso de humor e a espirituosidade cornelianas. Em sua ficção, embora não seja nunca muito freqüente e muito menos

\footnotetext{
57 "Pois carecia que um de nós nos recusasse / para melhor servir-nos." (Carlos Drummond de Andrade, "Os bens e o sangue", Poesia e prosa, p. 233.)

${ }^{58}$ Carta de 21 de abril de 1939.
} 
dominante, o riso claro e franco surge aqui e ali em meio à risada grotesca e à gargalhada cruel.

Personagens às vezes engraçados são a viúva bisbilhoteira, ao que parece sem ter sido um dia casada, em Repouso, e Sinhá Rola e Joviana, n’ A menina morta. Mas mesmo uma personagem sisuda como dona Virgínia pode provocar alguma risada. No episódio do retorno ao Grotão com Carlota da visita à condessa, a parenta do Comendador, apavorada com o desembestar dos animais que conduziam a vitória, o cocheiro lançado ao chão, prende-se ao vestido da moça com tal força, que precisaram depois "separar cada um dos seus dedos para libertar Carlota". Depois disso, recupera a calma e apeia do carro "com lenta majestade". Pouco depois, tenta se explicar: "Ficara tão aterrorizada diante da possibilidade de Carlota ser também atirada ao leito da estrada, que a agarrara pelo vestido com tal violência que ao chegarem não pudera abrir as mãos fechadas nervosamente..." (as reticências são do escritor).

O episódio em que Bruno lança o cavalo contra o negro esfarrapado, depois que este tinha separado e agrupado com facilidade os animais que o outro inutilmente procurava, a despeito da possível interpretação por mim mesmo sugerida, na esteira de outros estudos, como índice da hierarquia existente entre os próprios escravos e da introjeção por eles das relações senhor-escravo e mesmo da vingança possível no interior do cativeiro, contém também um aspecto de observação bem-humorada da realidade, tão próprio de chargistas e caricaturistas, com seu olhar tão agudo e sensível, afinado para a notação das atitudes miúdas do cotidiano, reveladoras das fraquezas do homem, para os detalhes da conduta humana, nem sempre louvável, risíveis porque essas atitudes e essa conduta são muitas vezes as nossas. Não há assim como também não rir dos impropérios lançados ao negro por Bruno, especialmente pelo exagero tão contrastante com o que o outro tinha feito, ao que parece do modo mais inocente: “Mocamau do inferno! [...] onde já se viu tamanho desaforo? Quem te mandou intrometer no que não é chamado? De uma surra de bacalhau é que tu precisavas!" E o modo como olha furtivamente para os lados para ser se alguém havia assistido o "desagradável episódio", só adquirindo a calma depois de tomar um "grande gole" da garrafa tirada do bolso, não deixa também de ser engraçado. O mesmo se pode dizer do castigo "efetivamente" aplicado, que seria não mais do que aquilo que devia ser a tarefa mesma do negro: “ - Vamos para o quarto dos arreios, e você vai me arriar bem essas mulas do diabo, senão!" 
Os originais de uma crônica pertencente ao acervo do escritor também podem confirmar que Cornélio não era avesso ao riso. Chama-se "Cena de feira" e relata uma visita - não se sabe se fictícia ou não - que teria feito a uma "Feira de livros". Trata-se de um texto curto, mas não há como transcrevê-lo integralmente. Reproduzo a seguir apenas dois trechos, parece-me que suficientes para que se possam entrever o talento do escritor para o humor e, ao mesmo tempo, a talvez igualmente insuspeitada visão moderna que tinha sobre a linguagem:

... vi dois volumes de Camilo Castelo Branco em exposição na barraquinha dos "Livros de Portugal" e pareceu-me que ainda não os tinha lido. Resolvi-me imediatamente a comprá-los e tirei-os do mostruário para dá-los à senhora encarregada, a fim de realizar a compra. Logo que os peguei, um jovem de óculos, figura característica de moço estudioso, daqueles que levam a vida a sério e tudo é solene e grave, murmurou-me ao ouvido: essa edição não merece confiança...! Disse-lhe risonhamente que estava comprando um romance e não um compêndio de linguagem portuguesa. Como falara em tom normal, os circunstantes ouviram, e imediatamente aquele grupo silencioso de pessoas que examinavam os livros animou-se e formou-se logo uma assembléia agitada e entusiasta. Um senhor, que era o retrato do acadêmico Austreségilo de Athayde, exclamou: mas como linguagem Camilo Castelo Branco é uma escola! O português que estava ao meu lado fez-me uma longa dissertação sobre Eça de Queiroz e sua superioridade sobre Camilo, ...

(...) É verdade que em um ponto estavam de absoluto acordo, que nos livros de Camilo aprendia-se a pureza de linguagem, e ficaram indignados todos quando disse que para esse fim seria melhor comprarmos uma gramática e aplicarmos suas regras em estilo nosso, conservando talvez nossa personalidade.

Por fim, deixo registrado um último exemplo da espirituosidade de Cornélio Penna, a que por vezes se referem amigos mais próximos, como Marques Rebelo. Tratase de uma entrevista de 1955 que ele concedeu a Maria Natália Rodrigues, de uma publicação chamada Revista Semana, que contém momentos graves e tocantes, com respostas muito reveladoras sobre a sua personalidade, mas que em alguns outros talvez não menos reveladores - provoca o riso, já pela forma como é transcrita ou pela mistura entre perguntas muito sérias e outras bastante banais, como também por algumas das respostas dadas pelo escritor: 
Ping: Seu prato predileto?

Pong: Vivo sob rigoroso regime, e sem esperanças...

Ping: Você suporta gente vazia?

Pong: Não sei o que significa a expressão, mas posso garantir-lhe que detesto "gente cheia", quer seja de inteligência, talentos, erudição, de tudo enfim que seja ornamento de aparato.

$[\ldots]$

Ping: Acha que uma mulher, para ser fabulosa, tem que ser ótima cozinheira?

Pong: No meu caso particular seria um grave defeito. 


\subsection{O romance corneliano em seu tempo e depois}

Todas as observações feitas até aqui, de modo algo (ou muito) aleatório e assistemático, intentam, ao menos como anelo, uma compreensão da obra corneliana que respeite a sua realidade complexa e muitas vezes contraditória, para além das classificações e dos rótulos. As aproximações que se procurou buscar desse universo (e muitas outras mais teriam lugar), embora não expliquem a obra e estejam longe de resolver o enigma do artista, são tentativas de entrever algumas de suas faces e facetas. "Não sou igual a mim mesmo", disse o escritor ${ }^{59}$. Estou certo de que também podia dizer com Mário de Andrade: "Eu sou trezentos, sou trezentos e cinqüenta, / Mas um dia afinal eu toparei comigo..."60 Sendo a realidade vivida igualmente plural e fragmentada, o que os seus romances e pinturas nos oferecem são alguns desses fragmentos artisticamente recriados ao tempo em que dão notícia dessa fragmentação. Nesse sentido, Cornélio Penna é um artista essencialmente moderno: “... the heart of Modernism is the postulate of ontological discontinuity. So much of the thought and art of the twentieth century follows from atomism that thus far there has been no going back on it, even in the ages of structuralism and postmodernism. We cannot help seeing the objects of our knowledge as discrete and discontinuous..."

Escapar dos rótulos e ultrapassar o "limite didático" da "triagem por tendências" (Alfredo Bosi) têm não apenas um significado geral de que, no estudo da literatura, as rotulações muitas vezes mais atrapalham que ajudam, como também a percepção de que no caso de um escritor como Cornélio Penna e de um período tão rico de nossa produção literária, seja no campo da poesia como no da prosa, elas são particularmente nocivas e prejudiciais. Insistir na divisão entre uma literatura social-regionalista e outra intimista ou psicológica, entre escritores regionalistas e escritores introspectivos, acaba por cristalizar em nosso imaginário o lugar de cada escritor e obra e por direcionar nossos passos de antemão para uma via de há muito conhecida, tornando muito difícil a opção por trilhar outros caminhos e mais ainda por abrir novas trilhas, em outras

\footnotetext{
59 Entrevista concedida a Maria Natália Rodrigues, "Cornélio Penna - O que desejou ser um pintor famoso".

${ }^{60}$ Foi Alcides Villaça quem me lembrou desse poema em seus comentários sobre parte deste trabalho. $\mathrm{O}$ melhor exemplo dessa pluralidade corneliana é a mistura entre o mais avançado - a proximidade das novas teorias da física, introdutoras dos conceitos de relatividade, incerteza e complexidade - e o mais arcaico - o catolicismo monarquista de feições messiânicas.

${ }^{61}$ William Everdell, The first moderns, p. 351.
} 
direções. Nosso olhar viciado olha, mas não vê, ou vê o que já foi tantas vezes visto. Contradizer a classificação desse ou daquele escritor, dessa ou daquela obra, passa a exigir uma espécie de desaprendizagem, um lançar fora do pesado lastro de todos os didatismos. Por isso, a importância da proposição de classificações mais produtivas, não para que se instalem confortavelmente no lugar daquela outra, mas para evidenciar as diversas possibilidades de se olhar para um período mais longo de um ponto de vista mais distante, quando parece mesmo necessária alguma sistematização.

Foi o que fez Alfredo Bosi ${ }^{62}$, ao perceber "que, além de ser precária em si mesma (pois regionais e psicológicas são obras-primas como São Bernardo e Fogo Morto), [a classificação tradicional e didática] acaba não dando conta das diferenças internas que separam os principais romancistas situados em uma mesma faixa." Então, a partir de uma formulação de Lucien Goldmann, apoiado por seu turno em distinções tomadas a Lukács e Girard, propõe uma divisão do romance "dos anos 30 para cá" que tem como parâmetro a "tensão entre o 'herói' e o seu mundo", homóloga à "tensão entre o escritor e a sociedade", ponto de partida de Goldmann. No caso de Cornélio Penna, Lúcio Cardoso, Cyro dos Anjos e outros escritores afins, teríamos os romances de "tensão interiorizada". Não vou tratar de toda a tipologia por ele empreendida, mas cabe observar que o seu pressuposto parece muito próximo daquele de Costa Lima, de que venho me utilizando neste trabalho, no reconhecimento de que há sempre nesse romance alguma tensão (mesmo que mínima) com o mundo. Todavia, a divisão proposta não é estanque, e o crítico passa em seguida a tratar das diferenças no interior mesmo de cada segmento, de acordo com os diferentes modos "de captar o ambiente e de propor a ação". Já Mário de Andrade refletira sobre a literatura contemporânea a partir de uma outra diferença, entre o que ele denominou, de um lado, "psicologia em ação" e, de outro, "psicologia em análise", e incluiu nesta última ninguém menos do que José Lins do Rego, sempre um exemplo quase imediato quando alguém se refere aos regionalistas ${ }^{63}$. Ora, tanto uma como outra trata da realidade e do homem e de sua psicologia, havendo apenas uma diferença de procedimentos. A primeira busca mostrar o interior do sujeito por meio de suas próprias ações; a segunda, da análise psicológica direta. E ainda acrescenta Mário: "tais distinções nada têm de intransponíveis".

Ao estabelecer uma tal distinção, concedendo ainda que ela não constitui compartimentos incomunicáveis, e ao frisar, por meio da própria denominação de cada

\footnotetext{
${ }^{62}$ História concisa da literatura brasileira, p. 440 e sgs..

${ }^{63}$ O empalhador de passarinho, p. 153-63.
} 
uma daquelas tendências, que ambas têm como centro a interioridade, Mário de Andrade parece apontar para um "fenômeno" que vinha ocorrendo na literatura ocidental pelo menos a partir do século XVII, marcado por uma "progressiva internalização dos eventos", como o denomina Erich Kahler, no livro não por acaso intitulado The Inward Turn of Narrative. E embora ele encerre a sua obra fundamental com o Tristran Shandy, não há como não pensar que essa virada para o interior tornouse ainda mais aguda ao longo do século XIX e, sobretudo, do século XX. Internalização dos eventos contudo não significa ausência deles. Isto é, a realidade - não só a do indivíduo e de sua interioridade - continua presente, mas filtrados, refletidos ou refratados na consciência do sujeito. Por isso, essa realidade surge cada vez mais relativizada, mais dependente de diferentes pontos de vista, de perspectivas diversas. Se a física somente começa a questionar o demônio de Laplace a partir do início do século XX ou no máximo ao final do XIX, a literatura e as artes o fazem muito antes disso.

No caso específico de Cornélio Penna, o rótulo de escritor "católico" talvez tenha feito ainda mais estrago que aquele de "intimista" ou "introspectivo". Neusa Pinsard Caccese, em seu livro sobre a revista Festa ${ }^{64}$, que agrupava artistas e escritores declaradamente católicos, como Andrade Murici, Tasso da Silveira, Barreto Filho, Murilo Araújo, Adelino Magalhães e Cecília Meirelles, na medida em que apresenta a revista e as posições de seus articulistas, transcreve diversas passagens de alguns dos artigos publicados. A leitura desses fragmentos comentados permite de fato reconhecer a existência de afinidades entre as posições de alguns articulistas e as de Cornélio Penna, expressas nas entrevistas que chegaram até nós ou que podem ser inferidas de seus livros. São exemplos dessa proximidade a afirmação da precedência do sentimento e da sensibilidade do artista sobre a forma da obra e da inconsciência de suas escolhas em sua realização, a insistência na revelação pela arte da "alma brasileira" e a condenação da desumanização do homem no mundo moderno "dominado pela máquina". É curioso, porém, que um jornalista e artista católico, prestes a lançar seu primeiro romance quando Festa entrava na sua segunda fase ${ }^{65}$, não tenha escrito um artigo sequer ou realizado uma única ilustração para uma revista publicada no Rio de Janeiro, onde morava, e que continha - salvo engano, sobretudo na segunda fase -

\footnotetext{
${ }^{64}$ Festa: contribuição para o estudo do Modernismo.

${ }^{65}$ A primeira fase de Festa ocorre entre 1927 e 1929; a segunda, entre 1934 e 1935, ano de publicação de Fronteira.
} 
desenhos e ilustrações, entre outros, de Cecília Meirelles e Cândido Portinari. Não teria sido convidado? Não teria aceitado participar?

Como quer que seja, mesmo se reconhecermos que também devia haver divergências entre os próprios artistas e intelectuais que faziam o grupo espiritualista de Festa, aquelas entre eles e Cornélio parecem muito mais significativas. Em alguns ensaios sobre arquitetura, comentados por Neusa Caccese, o autor rejeitaria "tanto o barroco 'esparramado' e de mau gosto, como o 'autêntico, do bom' - não originariamente brasileiros" $" 66$. Em outro artigo, é dito, ainda nas palavras da autora, que “ao período angustioso da 'desordem', comparado pela Revista ao Romantismo, sucederá o Classicismo equilibrado e lúcido, reinstaurando a 'ordem' indispensável"67. E, finalmente, para não nos estendermos muito aqui, depois de insistir o tempo todo na importância da "brasilidade", os articulistas de Festa em geral a associam à "civilização européia" somada à "força da terra", o que significa fundamentalmente a contribuição indígena, ainda que o negro não deixe de ser mencionado. Para Adelino Magalhães, Festa

É a corrente verdadeiramente civilizadora do País, aquela que começou a dar à mentalidade nacional uma complexidade e uma profundeza que lhe faltavam; é a corrente do Brasil-novo, Brasil-brasileiro mas desbarbarizado; é a corrente do Brasil-maior, afinal, adaptando nosso modo de ser sul-americano a suprema civilização ariana. ${ }^{68}$

Ora, se Cornélio Penna falara também em "alma brasileira", a sua compreensão parece inteiramente diversa dos espiritualistas ou católicos. Se chegara a apontar como “três 'motivos brasileiros' [que] se nos apresentam impressionantes em sua rede beleza: o Caboclo, o Índio e o Negro”, no artigo que esse mesmo Adelino Magalhães lhe pedira (teria sido para publicação na revista e fora recusado pelos editores?), é sem dúvida alguma o negro aquele a que dedicou a maior parte de sua obra romanesca ${ }^{69}$. Mais

\footnotetext{
${ }^{66}$ Op. cit., p. 52.

${ }^{67}$ Id. ibid., p. 44.

${ }^{68}$ Id. ibid., p. 63.

${ }^{69} \mathrm{O}$ interesse pela cultura africana, contudo, parece muito anterior à sua produção literária. Há no acervo do escritor o manuscrito (com algumas ilustrações) de um ballet intitulado Macumba (cenas da vida, do amor e da morte), sem data, mas muito provavelmente bem anterior à publicação de Fronteira, de que falta infelizmente uma das onze páginas numeradas pelo autor. Nesse mesmo acervo, pode-se também encontrar um dos mais belos trabalhos do pintor, uma roda de samba (?) realizada naquele estilo que tanto encantou Alexandre Eulálio.
} 
ainda, não parece haver em nenhum momento de sua produção qualquer menção à "suprema civilização ariana". Quando muito, Cornélio fala de seu amor e admiração por Portugal, que chega um dia a conhecer com a mulher. Mas um texto que ele escreve sobre essa visita revela, ironicamente, ter sido "muito, infinitamente mais real" a "viagem que [...] tinha feito, mentalmente" quando mergulhara, ainda menino, nos livros de Camilo Castelo Branco ${ }^{70}$. Apesar de muitos terem visto na literatura corneliana uma mistura entre o classicismo (leia-se realismo) do século XIX e o moderno do XX, parece-me - ainda que não o tenha desenvolvido neste trabalho - que a repercussão nessa obra das leituras românticas do escritor é bastante nítida, podendo-se dizer o mesmo do barroco, como vimos, do que não se pode absolutamente presumir um escritor empenhado em "desbarbarizar" o Brasil... E quanto à ordem, ao equilíbrio e à lucidez, se podem ser encontrados em Cornélio, estão sempre ao lado - e parece-me em constante desvantagem - da desordem, do desequilíbrio e da alucinação, e foi também nesse sentido que procurei mostrar algumas afinidades entre sua obra e a estética expressionista.

Não obstante, outros intelectuais e escritores católicos tentaram durante muito tempo ver e mostrar a obra corneliana como católica e espiritualista, cuja temática principal incluiria a salvação, o pecado, a humildade, a fé, a santidade etc. Tristão de Athayde, Octávio de Faria e, posteriormente, Adonias Filho seriam os mais importantes nomes dessa tendência. Dos três, ao que eu saiba, somente o primeiro aproximou-se - e assim mesmo depois de algum tempo - do grupo de Festa, que inclusive chegou a publicar alguns artigos seus. De todo modo, muitas das idéias dos espiritualistas - e infelizmente não há como desenvolvê-lo aqui - me parecem afins ao pensamento de Alceu Amoroso Lima ${ }^{71}$. Quanto a Octávio de Faria, em que pese o fato de ter sido $A$ tragédia burguesa - sobretudo no que se refere aos dois primeiros volumes injustamente menosprezada por boa parte da crítica $^{72}$, a sua é uma literatura inteiramente distinta da de Cornélio e - ela, sim - muito conforme ao realismo do Novecentos.

\footnotetext{
70 "Viagem a Portugal".

${ }^{71}$ V. Estudos: $1^{a}$ e $2^{a}$ séries e Estudos literários - vol.1, dentre outros, e Antônio Carlos Villaça, $O$ pensamento católico no Brasil.

${ }^{72}$ V. Luis Bueno, "Os três tempos do romance de 30", Teresa - revista de literatura brasileira, no $3 . \mathrm{Na}$ biblioteca do escritor, que se encontra no Instituto de Estudos da Linguagem da Unicamp, pude encontrar diversos volumes da Tragédia Burguesa com a dedicatória do autor a Cornélio Penna, sem marcas de leitura, com as páginas ainda unidas, como acontecia com as edições antigas. Como Cornélio era um leitor voraz, a impressão é que não se entusiasmava com a produção do amigo.
} 
Diziam de Cornélio Penna que, além de católico, era ele monarquista. Parece-me mesmo bastante provável, embora não me lembre de ter visto uma afirmação categórica dele nesse sentido, e o mais próximo disso é, salvo engano, o trecho de uma entrevista que deu em 1931, em que elogia a época da monarquia (de modo irônico?) e se volta contra os que criticam os monarquistas ${ }^{73}$. Mas há um curioso conto, entre o fantástico e o humorístico, escrito por ele, não sei se teria sido publicado, em que ele encontra no interior da igreja do Mosteiro de São Bento numerosas figuras do passado, sobretudo religiosos, mas também, dentre outros, Antônio Carlos de Andrada. Ao final, ouve-se chegar uma carruagem e todos se põem de pé. Era ninguém mais ninguém menos que "Dona Carolina Josefa Leopoldina, pobre imperatriz sem fausto e sem beleza", que vinha, segundo uma vizinha segreda a Cornélio, "suplicar a Deus o amor de seu marido..." (reticências do autor). De todo modo, como já mencionei uma vez, a impressão que tenho - advinda da leitura de seus romances e de tudo que ele deixou e a que pude ter acesso - é que essa mistura de catolicismo e monarquismo o aproximam muito menos do catolicismo oficial do que do catolicismo popular e dos movimentos messiânicos, daqueles que acreditam nos milagres e que misturam as figuras de São Sebastião e Dom Sebastião ${ }^{74}$, dos conselheiristas plenamente confiantes no advento do "reino de delícias prometido", prenunciado pela breve vitória da República - o AntiCristo - sobre a monarquia ${ }^{75}$, e ainda de todos os que acreditam no poder das relíquias e dos talismãs, que consideram mais sagrada uma choça na beira da estrada em que um milagre teria ocorrido do que uma igreja cheia de pompa e riqueza. Trata-se, como foi dito, apenas de uma impressão ou intuição, e ficam à espera quem sabe de estudos mais aprofundados nesse sentido que possam prová-lo ou venham a refutá-lo.

Todavia, ainda que assim fosse, não seria essa uma posição regressiva para não dizer reacionária? Como os outros espiritualistas e católicos, sejam aqueles da revista Festa, sejam Octávio de Faria ou Tristão de Athayde, que têm em comum a visão crítica

\footnotetext{
73 “... refugiei-me entre estes velhos quadros, entre estes antigos móveis, que reconstituem em bem pequeno uma época saborosa de preguiça e de gravidade nacionais, e acho que o 'saudosismo' é o melhor refúgio, e os pobres homens que tentaram ridicularizar os monarquistas com esse apelido, tiveram, certamente, só essa vez, um pouco de espírito, em suas tristes vidas." ("Uma entrevista com Cornélio Penna, o extraordinário pintor de 'Horas melancólicas' ".)

${ }^{74}$ Devo a Elena Pájaro Peres a lembrança sobre essa "confusão".

${ }^{75}$ Euclides da Cunha, Os sertões, p. 138. É esse "reino de delícias", verdadeiro país da Cocanha, que Cornélio Penna parece associar ao império em resenha publicada na imprensa: "É pena que os alemães e os franceses não tenham conhecimento do sucesso das cartas de Ina von Binzer porque certamente iriam vasculhar suas arcas e armários para ver se achavam cartas esquecidas de alguma avó ou tia-avó, que tivesse estado no Brasil, e escrevesse suas impressões sobre o nosso império que foi um delicioso país da felicidade." ("As cartas de Ulla", grifos meus.)
} 
com relação à "desumanização do homem, dominado pela máquina, reduzido a viver, superficialmente, a artificialidade das novas condições de vida", palavras que bem poderiam ter sido ditas em relação a Cornélio, e a recusa ao Liberalismo, por um lado, e ao "Bolchevismo", por outro, não teria o escritor se colocado ao lado do atraso e das tendências autoritárias de então? Como nesses casos, parece-me, não cabe à crítica julgar, mas compreender, a compreensão do papel de Cornélio Penna nesse contexto pode encontrar inspiração num outro caso e em outro contexto. Antes disso, é preciso ressaltar uma vez mais as diferenças em relação àqueles intelectuais e escritores. Não há notícia alguma de que Cornélio, como Alceu Amoroso Lima, tenha "namorado" o Integralismo $^{76}$, como vimos, e não parece, por outro lado, que tenha em algum momento pensado em fazer de sua obra uma bandeira a favor do espiritualismo e uma cruzada contra as teorias materialistas, encontrem-se elas à esquerda ou à direita. Em seus depoimentos encontramos sempre a intransigente defesa da liberdade e da independência do artista ainda que diante da Religião ${ }^{77}$.

O outro "caso" em outro contexto é o de ninguém menos que Goethe, e vai aqui sem mais comentários, apenas como contraponto ao de Cornélio Penna, desnecessário insistir em que isso não implica absolutamente qualquer sugestão no sentido do estabelecimento de outras relações entre um e outro. É de um belíssimo texto de Benjamin - difícil, estranho e tocante - que transcrevo alguns fragmentos:

Soret fez uma profunda observação sobre o poeta: "Goethe é liberal num sentido abstrato, mas na prática ele tende para os princípios mais reacionários.” [...] Poderio feudal sobre terras administradas, à maneira burguesa - esta é a imagem contraditória em que se manifesta a máxima felicidade de vida de Fausto.

Goethe morreu no dia 22 de março de 1832, logo após a conclusão da obra. Por ocasião de sua morte, a industrialização da Europa já se encontrava num

\footnotetext{
${ }^{76}$ Quem o afirma agora é um católico e grande admirador de Tristão de Athayde, acima de qualquer suspeita: "É visível que há um namoro, mas discreto, discretíssimo. Não chega a ser noivado..." (Antonio Carlos Villaça, O pensamento católico no Brasil, p. 17.) "Em Indicações políticas, de 1936, ainda aparece muito claramente o direitismo do jovem mestre, seu entusiasmo pela Espanha franquista, pelo Portugal salazarista, ou pelo integralismo brasileiro." (p. 191) Todavia, como foi visto no primeiro capítulo, ele não demora a se reconciliar "com o ideal democrático": "Alceu logo se colocou ao lado da França e da Inglaterra, contra o nazismo e o fascismo.” (p. 189)

${ }_{77}$ Depois de escrever essas considerações, acabei por ler alguns artigos publicados na imprensa por Cornélio Penna (v. Referências Bibliográficas) que talvez se aproximem de um certo proselitismo religioso, mas muito distante daquele de um Alceu Amoroso Lima e mesmo dos intelectuais de Festa. Além disso, embora não tenham data em sua maior parte, acredito serem dos anos 40 ou mais provavelmente da década de 50 e não dos anos 30. Seja como for, isso não muda nada do que foi dito sobre sua obra romanesca.
} 
crescimento desenfreado. Goethe previu esse desenvolvimento. Numa carta de 1825 a Zelter lê-se o seguinte: "Riqueza e rapidez, eis o que o mundo admira e o que todo o mundo quer. Ferrovias, correio expresso, navios a vapor, e todas as possíveis facilidades de comunicação são as coisas que o mundo culto deseja a fim de se sofisticar e assim persistir na mediocridade. [...] Atenhamo-nos tanto quanto possível à mentalidade na qual fomos criados: nós, e alguns poucos, seremos talvez os últimos de uma época que tão cedo não retornará."

Mas, apesar da literatura incalculável sobre Goethe que a filologia produziu, a burguesia, para seus objetivos, só pôde se utilizar de maneira incompleta, desse espírito fabuloso, sem mencionar até que ponto ela conseguiu compreender suas intenções.Toda sua produção está repleta de reservas contra essa classe. E se ele lhe ofertou uma obra poética de alto valor, ele o fez de rosto virado. [...] E assim agiu ele para dar aos conteúdos que existiam dentro dele a forma que resistiu até hoje à sua dissolução pela burguesia, porque embora essa forma tenha permanecido ineficaz, não pôde ser falseada nem banalizada. ${ }^{78}$

Alternâncias como aquelas entre luz e sombra, muito embora num tempo que, dos segundos de um relâmpago na noite escura, passa àquele dos calendários em que os homens acompanham a passagem inexorável dos anos. Sucesso e reconhecimento em vida $^{79}$; esquecimento que se inicia logo após a morte ${ }^{80}$. Não obstante, num período como no outro, importantes críticos de diversas regiões do país - fora da Universidade e dentro dela - enveredam por essa obra, deixando abertos caminhos e trilhas, mais longos ou mais curtos, mais estreitos ou mais largos, mais ou menos íngremes, mas que sempre vale a pena percorrer. A constituição do acervo do escritor junto ao Arquivo-

\footnotetext{
78 "Goethe", Documentos de cultura, documentos de barbárie, p. 61-2. Este texto foi indicado pelo prof. Marcus Vinícius Mazzari, em seu curso de pós-graduação sobre o motivo do pacto em Goethe, Thomas Mann e Guimarães Rosa.

${ }^{79}$ Já comentei a respeito do grande êxito obtido pelo escritor quando do lançamento de Fronteira (V. nota 4 - Cap. 1). Repouso teria obtido o primeiro lugar como o melhor romance do ano (1948) em concurso promovido pelo suplemento literário do Correio da Manhã. E em 1955, Cornélio Penna recebeu o Prêmio Carmen Dolores (1954), de São Paulo, pela publicação de A menina morta. Maria Eugênia Celso comenta em artigo o sucesso do livro: "Não se pode deixar de falar nele. Eu já chego atrasada até. E 'A menina morta' é mais do que bom, é excelente. O sucesso que a acolheu veio mais uma vez pôr em foco o nome já consagrado de Cornélio Penna e o feitio tão característico que desde Fronteira o notabiliza." ("A menina morta", Jornal do Brasil, 29/03/55.)

${ }^{80} \mathrm{O}$ melhor exemplo da quase inacreditável rapidez na mudança dessa consagração em vida para o relativo esquecimento pouco depois da morte são os recibos de J. Aguillar relativos ao pagamento à viúva dos direitos autorais sobre as vendas dos Romances completos, constantes do acervo do escritor. Do lançamento em 1958 ao final de 1959, foram vendidos 1.657 exemplares de uma edição de cinco mil. Durante todo o ano de 1960, apenas 67 exemplares.
} 
Museu de Literatura da Fundação Casa de Rui Barbosa, com tudo o que foi doado por sua esposa, Dona Maria Odília, incluindo-se aí boa parte de sua produção pictórica, passou a permitir um conhecimento mais aprofundado sobre alguns dos muitos Cornélios, como o fez com o Cornélio-pintor, de maneira ímpar, Alexandre Eulálio. Alguns anos antes disso parece que seus romances já não eram encontrados facilmente nas livrarias até delas desaparecerem de todo. Após alguns anos, reaparecem aqui e ali nas belas publicações da editora Artium, para novamente sumirem poucos anos depois. Ainda raros mesmo nas bibliotecas, ao mesmo tempo em que é reeditada a obra pioneira de Luiz Costa Lima, começam a ressurgir, pela via indireta dos trabalhos acadêmicos, em algumas das universidades públicas deste país, como a Universidade Federal de Minas Gerais, a Universidade Estadual de Campinas e a Universidade de São Paulo. A despeito disso, o escritor permanece um enigma. Não é esse o motivo mesmo do interesse que desperta e de sua atualidade? 


\section{Referências bibliográficas}

\section{Obras de Cornélio Penna, entrevistas e correspondência recebida}

\subsection{Romances}

PENNA, Cornélio. A menina morta. Rio de Janeiro: Artium, 2001. . Dois romances de Nico Horta. Rio de Janeiro: Artium, 2000. . Fronteira. Prefácio de Léo Schlafman. Rio de Janeiro: Artium, 2001. . Repouso. Prefácio de Letícia Malard. Rio de Janeiro: Artium, 1998. . Romances completos. Rio de Janeiro: José Aguilar, 1958.

\subsection{Textos manuscritos}

PENNA, Cornélio. Macumba (o baile da vida, do amor e da morte). S.d.* . O nosso tão estranhamente... S.d.*

\subsection{Textos datilografados}

PENNA, Cornélio. Cena de feira. S.d.* . Uma noite eu passeava... S.d.* . Viagem a portugal. S.d.* . Quando fizemos a primeira... S.d.*

\subsection{Artigos em periódicos}

PENNA, Cornélio. As cartas de Ulla. [artigo de jornal], [16.3.57].* A aversão ao mistério. [A manhã], [12.5.56]* . Caráter encoberto. [artigo de jornal], S.d.* . Chama sagrada. [artigo de jornal], S.d.* . Itabirismo: texto e ilustrações de Cornélio Pena. O Cruzeiro, 9.10.37. . Lembrança da Casa da Rua Princesa Januária. [O jornal], Rio de Janeiro, [12.6.55].* 
. Linha de sombra. [Correio da manhã?], [12.11.55].*

. Machado de Assis: um inédito de Cornélio Penna. [Jornal do

Comércio], [3.10.18?].*

. Um escritor fala de sua província: Minas. [artigo de jornal], s.d.*

\subsection{Obra pictórica}

Pinturas e desenhos, esboços, esboços a lápis, bicos-de-pena, esboços bicos-de-pena, guaches, aquarelas, pastéis-carvão, pastel sobre papel, óleos, técnicas mistas, óleo sobre tela, realizados por Cornélio Penna.*

\subsection{Entrevistas com Cornélio Penna}

AS MULHERES reconstroem, com doçura e suavidade, o que os homens destroem.

[Tribuna da Imprensa], [21.10.55].*

IVO, Ledo. A vida misteriosa do romancista Cornélio Penna. In: Romances completos.

Rio de Janeiro: José Aguilar, 1958.

MACEDO, Sergio D. Macedo. Programa "Convite à literatura”. 12.7.49 (texto datilografado).*

RODRIGUES, Maria Natália. Cornélio Penna - O que desejou ser um pintor famoso.

[Revista Semana], [11.6.55].*

UMA ENTREVISTA com Cornélio Penna, o extraordinário pintor de "Horas Melancólicas". [Beira-Mar], [31.10.31].*

\subsection{Correspondência recebida}

Cartas enviadas a Cornélio Penna e à sua mulher, dona Maria Odília de Oliveira Penna, por Carlos Drummond de Andrade (21.4.39), Lúcio Cardoso, Alceu Amoroso Lima, Cândido Portinari, Augusto Frederico Schmidt, Murilo Mendes, Marques Rebelo, Octavio de Faria e outros.

\footnotetext{
* Acervo de Cornélio Penna / Arquivo-Museu de Literatura Brasileira - Fundação Casa de Rui Barbosa
} 


\section{Bibliografia sobre Cornélio Penna}

ADONIAS FILHO. Cornélio Penna: romance. Rio de Janeiro: Livraria Agir, 1960. Cornelio Penna. In: COUTINHO, Afrânio et alii. A literatura no Brasil, o Modernismo. Rio de Janeiro: Sul Americana, 1970. . O coração violado. Modernos ficionistas brasileiros. Rio de Janeiro: Edições O Cruzeiros, 1958.

. Os romances da humildade. In: PENNA, Cornélio. Romances

completos. Rio de Janeiro: José Aguilar, 1958.

ALBERGARIA, Maria Consuelo de Pádua Albergaria. O espaço da loucura em Minas Gerais: análise da ficção de Cornélio Penna. Rio de Janeiro: UFRJ, 1982 (Tese de doutorado).

ANDRADE, Mário de. Romances de um antiquário. O empalhador de passarinho. $4^{\mathrm{a}}$ ed. Belo Horizonte: Itatiaia, 2002.

ARAÚJO, Laís Corrêa de. O coração ferido do homem. Minas Gerais - Suplemento Literário, Belo Horizonte, s.d., p. 7, Seção Roda Gigante.

ARAÚJO, Murilo. Nota preliminar: O gênio macabro de Cornelio Penna. In: PENNA, Cornélio. Romances completos. Rio de Janeiro: José Aguilar, 1958.

ATAÍDE, Tristão de. Nota preliminar. In: PENNA, Cornélio. Romances completos. Rio de Janeiro: José Aguilar, 1958.

BILHARINHO, Guido. O universo fechado de Cornélio Penna, Minas Gerais Suplemento Literário, Belo Horizonte, s.d., p. 3.

BOSI, Alfredo. História concisa da literatura brasileira. $3^{\text {a }}$ ed. S.Paulo: Cultrix, 1990.

BRUNO, Haroldo. Um romance de Cornelio Penna. Estudos de Literatura Brasileira. Rio de Janeiro: Edições O Cruzeiro, 1957.

BUENO, Luis. Um desbravador original. Caderno Mais! da Folha de São Paulo, 22.2.98.

CANDIDO, Antonio \& CASTELLO, José Aderaldo. Presença da Literatura Brasileira: Modernismo. 10 a ed. Rio de Janeiro: Bertrand Brasil, 1997.

CELSO, Maria Eugênia. “A menina morta”. [Jornal do Brasil], Rio de Janeiro, [29.3.55].*

CÉSAR, Guilhermino. Cornélio, o de Itabira. Minas Gerais - Suplemento Literário, Belo Horizonte, 23.11.74. 
CUNHA, Fausto. Forma e criação em Cornelio Penna. Situações da ficção brasileira.

Rio de Janeiro: Paz e Terra, 1970.

EULÁLIO, Alexandre. Os dois mundos de Cornelio Penna. Escritos. Org. Berta Waldman e Luiz Dantas. Campinas: Ed. da Unicamp; São Paulo: Editora da Unesp, 1992.

Os dois mundos de Cornelio Penna. Rio de Janeiro: Fundação

Casa de Rui Barbosa - Arquivo-Museu de Literatura Brasileira, 1979.

HERBOLD, Hildegard. O sagrado e o profano na literatura intimista dos anos 1930/40 no Brasil: o exemplo de Lúcio Cardoso e Cornélio Pena. São Paulo: FFLCH / USP, 1993 (Dissertação de mestrado).

IVO, Ledo. A vida misteriosa do romancista Cornelio Penna. In: PENNA, Cornélio. Romances completos. Rio de Janeiro: José Aguilar, 1958.

LIMA, Luiz Costa. A perversão do trapezista: o romance em Cornélio Penna. Rio de Janeiro: Imago; São Paulo: Secr. Cultura, Ciência e Tecnologia Estado S.Paulo, 1976. O romance em Cornélio Penna. $2^{\mathrm{a}}$ ed. Belo Horizonte: Ed. UFMG, 2005 . Sob as trevas da melancolia: o patriarcado em A menina morta. A aguarrás do tempo: estudos sobre a narrativa. Rio de Janeiro: Rocco, 1989.

LOPES, Edward. A palavra e os dias. Campinas: Editora da Unicamp, São Paulo: Editora da Unesp, 1993.

MAGAlHÃES, Adelino. Cornélio Penna. [O Brasil], [ca.1922 ou 1923]*

MENDES, Murilo. Cornélio Pena. Transístor. Rio de Janeiro: Nova Fronteira, 1980.

MILLIET, Sérgio. Diário Crítico. $2^{\mathrm{a}}$ ed. São Paulo: Livraria Martins / Editora da Universidade de São Paulo, 1951, Vol.VIII. Nota preliminar. In: PENNA, Cornélio. Romances completos. Rio de Janeiro: José Aguilar, 1958.

MIRANDA, Wander Melo. A Menina Morta: a insuportável comédia. Belo Horizonte: UFMG, 1979 (Dissertação de mestrado). . Ficção poética e de atmosfera: Cornélio Penna e Lúcio Cardoso. In: Seminário de João Alphonsus: a ficção mineira de Bernardo Guimarães aos primeiros modernistas. Belo Horizonte: Conselho Est. Cultura de Minas Gerais, 1982. 
OSAKABE, Haquira. Cornélio Penna, uma reedição oportuna. D.O. Leitura, Campinas: Depto. Teoria Literária Unicamp, mar.2003, ano 21, n.03.

PEREIRA, Lúcia Miguel. Casa e romance. Escritos da maturidade: seleta de textos publicados em periódicos (1944-1959). Rio de Janeiro: Ghraphia Editorial, 1994.

PEREZ, Renard. Escritores brasileiros contemporâneos. Rio de Janeiro: Civilização Brasileira, 1960 (1ª́rie).

. Cornélio Penna. Escritores Brasileiros Contemporâneos. [Correio da Manhã], [15.10.55].*

PLACER, Xavier. Cornélio Pena. Minas Gerais - Suplemento Literário, Belo Horizonte, 26.3.77, p. 3.

REBELO, Marques. Cornélio Penna. [Para Todos], [30.3.58].*

RUFINONI, Simone Rossinetti. Favor e melancolia: uma leitura de A menina morta, de Cornélio Penna. São Paulo: FFLCH / USP, 2005 (Tese de doutorado).

SAMPAIO, Roberta de Castro. Os arquivos implacáveis de João Conde: edição facsimilar acompanhada de estudos e notas. São Paulo: USP, 2003 (Dissertação de mestrado).

SANTILLI, Maria Aparecida. Angústia e fantástico no romance de Cornélio Penna. Revista de Letras, Assis: Editora de FFCLA, 1964, vol.5. . "A menina morta" de Cornélio Penna - o nacionalismo e o intimismo. África. Lisboa, jul.1978, 1: 77-80.

SANTOS, Josalba Fabiana dos. Fronteiras da nação em Cornélio Penna. Belo Horizonte: UFMG, 2004 (Tese de doutorado).

SCHINCARIOL, Marcelo Tadeu. Em busca da alma de Itabira: uma leitura de Cornélio Penna. Campinas: Unicamp / Instituto de Estudos da Linguagem, 2001 (Dissertação de mestrado).

SCHMIDT, Augusto Frederico. Nota preliminar. In: PENNA, Cornélio. Romances completos. Rio de Janeiro: José Aguilar, 1958.

SIMÕES, Irene Jeanete Gilberto. Oficina de artista: a linguagem dos romances de Cornélio Penna. São Paulo: USP, 1990 (Tese de Doutorado).

VILLAÇA, A. C. “A menina morta”. [artigo de jornal], s.d.*

\section{* Acervo do escritor / Arquivo-Museu de Literatura Brasileira - Fundação Casa de Rui Barbosa}




\section{Bibliografia Geral}

ADORNO, Theodor W. Minima moralia: reflexões a partir da vida danificada. $2^{\mathrm{a}}$ ed.

Trad. de Luiz Eduardo Bicca. São Paulo: Ática, 1993.

Notas de literatura I. Trad. Jorge de Almeida. São Paulo:

Livraria Duas Cidades / Ed. 34, 2003 (Coleção Espírito Crítico).

ANDRADE, Carlos Drummond de. Poesia e prosa. $8^{\text {a }}$ ed. Rio de Janeiro: Nova Aguilar, 1992.

ANDRADE, Mário de. O empalhador de passarinho. $4^{\mathrm{a}}$ ed. Belo Horizonte: Itatiaia, 2002. . Aspectos da literatura brasileira. $5^{\mathrm{a}}$ ed. São Paulo: Martins, 1974.

ATHAYDE, Tristão de [Alceu Amoroso Lima]. Estudos: $2^{a}$ série. Rio de Janeiro: Terra de Sol, 1928.

. Estudos: $1^{a}$ série. Rio de Janeiro: Terra de Sol, 1927.

Adeus à disponibilidade e outros adeuses. Rio de Janeiro: Livraria

Agir, 1969.

AUERBACH, Erich. Mimesis: a representação da realidade na literatura ocidental. $2^{\mathrm{a}}$ ed. São Paulo: Perspectiva, 1987.

ÁVILA, Affonso. O Modernismo. 2a ed. São Paulo: Perspectiva, 2002.

BATAILLE, Georges. La littérature et le mal. Éditions Gallimard, 1957.

. O Erotismo. $3^{\mathrm{a}}$ ed. Trad. João Bénard da Costa. Lisboa:

Edições Antígona, 1988.

BENJAMIN, Walter. Goethe. Documentos de cultura, documentos de barbárie: escritos escolhidos. Sel. Willi Bolle; trad. Celeste H.M. Ribeiro de Sousa et alii. São Paulo: Cultrix / Edusp, 1986. . Magia e Técnica, Arte e Política - Ensaios sobre literatura e história da cultura. $5^{\text {a }}$ ed. São Paulo: Brasiliense, 1993.

BIRMAN, Joel. Estilo e modernidade em Psicanálise, São Paulo: Ed. 34, 1997.

BOHR, Niels. Física atômica e conhecimento humano: ensaios 1932-1957. Trad. Vera Ribeiro. Rio de Janeiro: Contraponto, 1995.

BOSI, Alfredo. História concisa da literatura brasileira. $3^{\text {a }}$ ed. S.Paulo: Cultrix, 1990. . Céu e inferno: ensaios de crítica literária e ideológica. São Paulo: Ática, 1988.

. Dialética da colonização. $3^{\text {a }}$ ed. São Paulo: Cia. das Letras, 1992. 
BUENO, Luís. Guimarães, Clarice e antes. Teresa - revista de Literatura

Brasileira. São Paulo: Editora 34, 2002 (nº 2).

Os três tempos do romance de 30. Teresa - revista de Literatura

Brasileira. São Paulo: Editora 34, 2002 ( $\mathrm{n}^{\circ}$ 3).

. Uma história do romance de 30. São Paulo: Edusp ; Campinas:

Editora Unicamp, 2006.

CACCESE, Neusa Pinsard. Festa: Contribuição para o estudo do Modernismo. São

Paulo: Instituto de Estudos Brasileiros / USP, 1971.

CALVINO, Ítalo. "Les niveaux de la réalité em littérature”. La machine littérature.

Trad. de Michel Orcel e François Wahl. Paris: Éditions du Seuil, 1984.

CANDIDO, Antonio. A educação pela noite \& outros ensaios. $2^{\mathrm{a}}$ ed. São Paulo: Ática, 1989.

. Literatura e sociedade. $2^{\mathrm{a}}$ ed. São Paulo: Cia. Editora Nacional,

1967.

(org.). Sérgio Buarque de Holanda e o Brasil. São Paulo, Ed.

Fundação Perseu Abramo, 1998.

Teresina etc. $2^{\text {a }}$ ed. Rio de Janeiro: Paz e Terra, 1992.

CARDOSO, Lúcio. Diário completo. Rio de Janeiro: José Olympio, 1973.

CARVALHO FRANCO, Maria Sylvia. Homens livres na ordem escravocrata. $4^{\mathrm{a}}$ ed.

São Paulo: Ed. da Unesp, 1997.

CERTEAU, Michel de. A invenção do cotidiano - 1. Artes de fazer. $10^{\mathrm{a}}$ ed. Trad.

Ephraim Ferreira Alves. Petrópolis: Vozes, 2004.

CHASTEL, André. A arte italiana. Trad. Antônio de Pádua Danesi. São Paulo: Martins Fontes, 1991.

CUNHA, Euclides da. Os sertões. 36 ${ }^{\mathrm{a}}$ ed. Rio de Janeiro: F. Alves, 1995.

DEBORD, Guy. A sociedade do espetáculo. Trad. Estela dos Santos Abreu. Rio de Janeiro: Contraponto, 1997.

DIAS, Maria Odila Leite da Silva. A interiorização da metrópole e outros estudos. São Paulo: Alameda, 2005.

. Quotidiano e poder em São Paulo no século XIX. $2^{\mathrm{a}}$ ed. rev.

São Paulo: Brasiliense, 1995.

DOSTOIÉVSKI, Fiódor. Os demônios. Trad. de Paulo Bezerra. São Paulo: Ed. 34, 2004. 
EVERDELL, William R. The first moderns: profiles in the origins of twentieth-century thought. Chicago and London: The University of Chicago Press, 1997.

FAUSTO, Boris. História do Brasil. $4^{\mathrm{a}}$ ed. São Paulo: Edusp, 1996. . A Revolução de 1930 - Historiografia e história. $9^{a}$ ed. São Paulo: Brasiliense, 1983. . Um fragmento da escravidão. Caderno Mais! da Folha de S.Paulo, 19.11.2006.

FRAZER, James. The golden bough - a study in magic and religion. Hertfordshire: Wordsworth, 1993.

FREUD, Sigmund. Cinco lições de psicanálise; A história do movimento psicanalítico; O futuro de uma ilusão; O mal-estar na civilização; Esboço de psicanálise I Sigmund Freud. Trad. de Durval Marcondes et al. São Paulo: Abril Cultural, 1978 (Os pensadores). . Além do princípio do prazer. Trad. de Christiano Monteiro Oiticica. Rio de Janeiro: Imago, 1998. Delírios e sonhos na Gradiva de Jensen. 'Gradiva' de Jensen e outros trabalhos. Obras completas - vol. IX. Rio de Janeiro: Imago, 1976. O Estranho. História de uma Neurose Infantil e Outros Trabalhos. Obras Completas - vol. XVII. Rio de Janeiro: Imago, 1976. "Totem e tabu". Obras Psicológicas Completas de Sigmund Freudvol. XIII. Rio de Janeiro: Imago, 1974.

FREYRE, Gilberto. Casa-grande e senzala: formação da família brasileira sob o regime de economia patriarcal. (2 volumes) 14 ed. Rio de Janeiro: José Olympio, 1969.

GADAMER, Hans-Georg. Verdade e Método I - Traços fundamentais de uma hermenêutica filosófica. Trad. Flávio Paulo Meurer. $7^{\mathrm{a}}$ ed. Petrópolis, RJ: Vozes, Bragança Paulista, SP: Editora Universitária São Francisco, 2005.

GARCIA-ROZA, Luiz Alfredo. O mal radical em Freud. $4^{\text {a }}$ ed. Rio de Janeiro: Jorge Zahar, 1990.

GINZBURG, Carlo. O queijo e os vermes: o cotidiano e as idéias de um moleiro perseguido pela Inquisição. Trad. de Maria Betânia Amoroso. $3^{\mathrm{a}}$ ed. São Paulo: Companhia das Letras, 1987.

GIRARD, René. A Violência e o sagrado. Trad. de Martha Conceição Gambini. São Paulo: Paz e Terra/Editora Unesp, 1990. 
GOMBRICH, E. H. The story of art. $16^{\text {th }}$. ed. Phaidon, 1995.

HAVELOCK, Eric A. A musa aprender a escrever: Reflexões sobre a oralidade e a literacia da Antiguidade ao presente. Trad. de Maria Leonor Santo Bárbara. Lisboa: Gradiva, 1996. . A revolução na escrita na Grécia e suas conseqüências culturais.

Trad. de Ordep José Serra. São Paulo, Editora da Universidade Estadual Paulista; Rio de Janeiro: Paz e Terra, 1996.

HEIDEGGER, Martin. A questão da técnica. Trad. de Emmanuel Carneiro Leão.

Ensaios e conferências. $3^{\mathrm{a}}$ ed. Petrópolis: Vozes; Bragança Paulista: Ed.

Universitária São Francisco, 2006.

HOBSBAWN, Eric. Era dos extremos: o breve século XX - 1914-1991. Trad. de

Marcos Santarrita. 2a ed. São Paulo: Cia. das Letras, 1995.

HOLANDA, Sérgio Buarque de. Caminhos e fronteiras. $3^{\text {a }}$ ed. São Paulo: Cia. das Letras, 1994.

. Cobra de vidro. São Paulo: Perspectiva, 1978. . O espírito e a letra: estudos de crítica literária 1, 1920-1947.

Org. Antonio Arnoni Prado. São Paulo: Companhia das Letras: 1996. . Livro dos prefácios. São Paulo: Cia. das Letras, 1996. . Raízes do Brasil. 9a ed. Rio de Janeiro: J. Olympio, 1976. . Tentativas de mitologia. São Paulo: Perspectiva, 1979.

HORKHEIMER, Max e ADORNO, Theodor W. Dialética do esclarecimento: fragmentos filosóficos. Trad. de Guido Antonio de Almeida. Rio de Janeiro: Jorge Zahar, 1985.

JOÃO DA CRUZ, São. Poesias completas = San Juan de la Cruz: Poesías completas . Trad. de Maria Salete Bento Cicaroni. São Paulo: Consejería de Educación de la Embajada de Espana, 1991.

KAHLER, Erich. The Inward Turn of Narrative. Transl. by Richard \& Clara Winston. New Jersey: Princeton University Press, 1973.

KAYSER, Wolfgang. Análise e Interpretação da Obra Literária. Coimbra: Arménio Amado Ed., 1985.

LAFETÁ, João Luiz. 1930: A crítica e o Modernismo. São Paulo: Duas Cidades / Ed. 34, 2000.

LAMBERT, Rosemary. A arte do século XX - História da arte da Universidade de Cambridge. São Paulo: Circulo do Livro, s/d. 
LIMA, Alceu Amoroso. Estudos literários - Volume 1. Rio de Janeiro: José Aguilar, 1966.

LIMA, Luiz Costa. As linguagens do Modernismo. In: ÁVILA, Affonso. $O$ Modernismo. $2^{\mathrm{a}}$ ed. São Paulo: Perspectiva, 2002. Hermenêutica e abordagem literária. Teoria da Literatura em suas fontes: vol. 1. $2^{\mathrm{a}}$ ed. ver. e ampl. Rio de Janeiro: F. Alves, 1983. . Mímesis: desafio ao pensamento. Rio de Janeiro: Civilização Brasileira, 2000.

LINHARES, Temistocles. O drama interior. História crítica do romance brasileiro: 1728-1981. Belo Horizonte: Itatiaia; São Paulo: Editora da Usp, 1987, pp. 35-71 (vol. III)

LINS, Álvaro. O romance brasileiro contemporâneo. Rio de Janeiro: Ed. de Ouro, 1967.

MAGNANI, José Guilherme Cantor. Festa no pedaço: cultura popular e lazer na cidade. $3^{\text {a }}$ ed. São Paulo: Hucitec / Unesp, 2003.

MERLEAU-PONTY, Maurice. O olho e o espírito. Trad. de Paulo Neves e Maria Ermantina Galvão Gomes Pereira. São Paulo: Cosac \& Naify, 2004.

MICELI, Sérgio. Intelectuais à brasileira. São Paulo: Cia. das Letras, 2001.

MOURÃO, Rui. A ficção modernista de Minas. In: ÁVILA, Affonso. O Modernismo. $2^{a}$ ed. São Paulo: Perspectiva, 2002.

ONG, Walter J. Orality and Literacy - The Technologizing of the World. London and New York: Routledge, 1991.

PEDROSA, Mário. Panorama da pintura moderna. Modernidade cá e lá: textos escolhidos IV. Org. Otília Arantes. São Paulo: Edusp, 2000.

PERRY, Gill. O primitivismo e o "moderno", In: HARRISON, Charles et alii. Primitivismo, Cubismo, Abstração: começo do século XX. Trad. de Otacílio Nunes. São Paulo: Cosac \& Naify, 1998.

PRIGOGINE, Ilya. As Leis do Caos. Trad. de Roberto Leal Ferreira. São Paulo: Editora UNESP, 2002. O fim das certezas - tempo, caos e as leis da natureza. Trad. de Roberto Leal Ferreira. São Paulo: Ed. da Unesp, 1996.

PRIGOGINE, Ilya \& STENGERS, Isabelle. La nouvelle alliance. Gallimard, 1986.

ROSENFELD, Anatol. Reflexões sobre o romance moderno. Texto/Contexto. $4^{a}$ ed. São Paulo: Perspectiva, 1985. 
SALIBA, Elias Thomé. Raízes do riso. São Paulo: Cia. das Letras, 2002.

SÉRGIO Buarque de Holanda: vida e obra. São Paulo, Secretaria de Estado da Cultura: Arquivo do Estado / Universidade de São Paulo: Instituto de Estudos Brasileiros, 1988. (Comissão organizadora: Arlinda Rocha Nogueira, Floripes de Moura Pacheco, Márcia Pilnik e Rosemarie Érika Horch.)

SEVCENKO, Nicolau. Orfeu extático na metrópole: São Paulo, sociedade e cultura nos frementes anos 20. São Paulo: Cia. das Letras, 1992. . Literatura como missão: tensões sociais e criação cultural na Primeira República. $2^{\mathrm{a}}$ ed. São Paulo: Cia. das Letras, 2003. Pindorama revisitada: cultura e sociedade em tempos de virada. $2^{a}$ ed. São Paulo: Peirópolis, 2000. (Série Brasil cidadão) (org.) História da vida privada no Brasil - vol. 3. São Paulo: Cia. das Letras, 1998.

SKIDMORE, Thomas. Brasil: de Getúlio Vargas a Castelo Branco, 1930-1964. $13^{\mathrm{a}} \mathrm{ed}$. São Paulo: Paz e Terra, 2003.

SOUZA, Neusa Santos. O estrangeiro: nossa condição. In: KOLTAI, Caterina (org.). $O$ estrangeiro. São Paulo: Escuta / Fapesp, 1998.

THOMAS, Keith. Religion and the Decline of Magic: Studies in Popular Beliefs in Sixteenth- and Seventeenth-Century England. London: Penguin Books, 1991.

VILLAÇA, Alcides. Querer, poder, precisar: "O caso da vara”. Teresa: revista de literatura brasileira. São Paulo: Ed. 34, 2006 (nº 6 7).

VILLAÇA, Antonio Carlos. O pensamento católico no Brasil. Rio de Janeiro: Civilização brasileira, 2006.

WALLERSTEIN, Immanuel. O tempo, a duração e o terceiro não-excluído. In: LOPES, Marcos Antônio (org.). Fernand Braudel: tempo e história. Rio de Janeiro: Editora FGV, 2003.

WILLIAMS, Eric. Capitalism and Slavery. New York: Capricorn Books, 1966.

WILLIAMS, Raymond. O campo e a cidade: na história e na literatura. Trad. de Paulo Henriques Britto. São Paulo: Cia. das Letras, 1989. 
jego o acantho, ifranco-germanico a flor de lys, o pre-colornhiano a serpente, o tuidin o elefhante?

of Lendereia fhilsophica, 0 misticisno higuhe, a simfles preoccufaqub de belleza infassivel, o idealinuo medrival de greira e de purega, - fatalismo e a idéa das forces physier dominades pela intelligerria nelles se demuciain.

Nat enconthands wa vatireza que o cerca enes syubols, o hourem crea o cirpantheno, conso o jafonez, on o grypho e micario consos enropen, ora dragus, corro o ching.

$$
\times
$$

Trez" notion hasileirs "se us apresentam, impressionantes sua sude filleza: o Cataclo, o Indis eo Negro. Oh! mas nin isca caloclo, ene indio esse negro que estain halituados a ver verona juitiora e

Cornélio Penna - [0 nosso tão estranhamente...] (página 10 do manuscrito)

268 


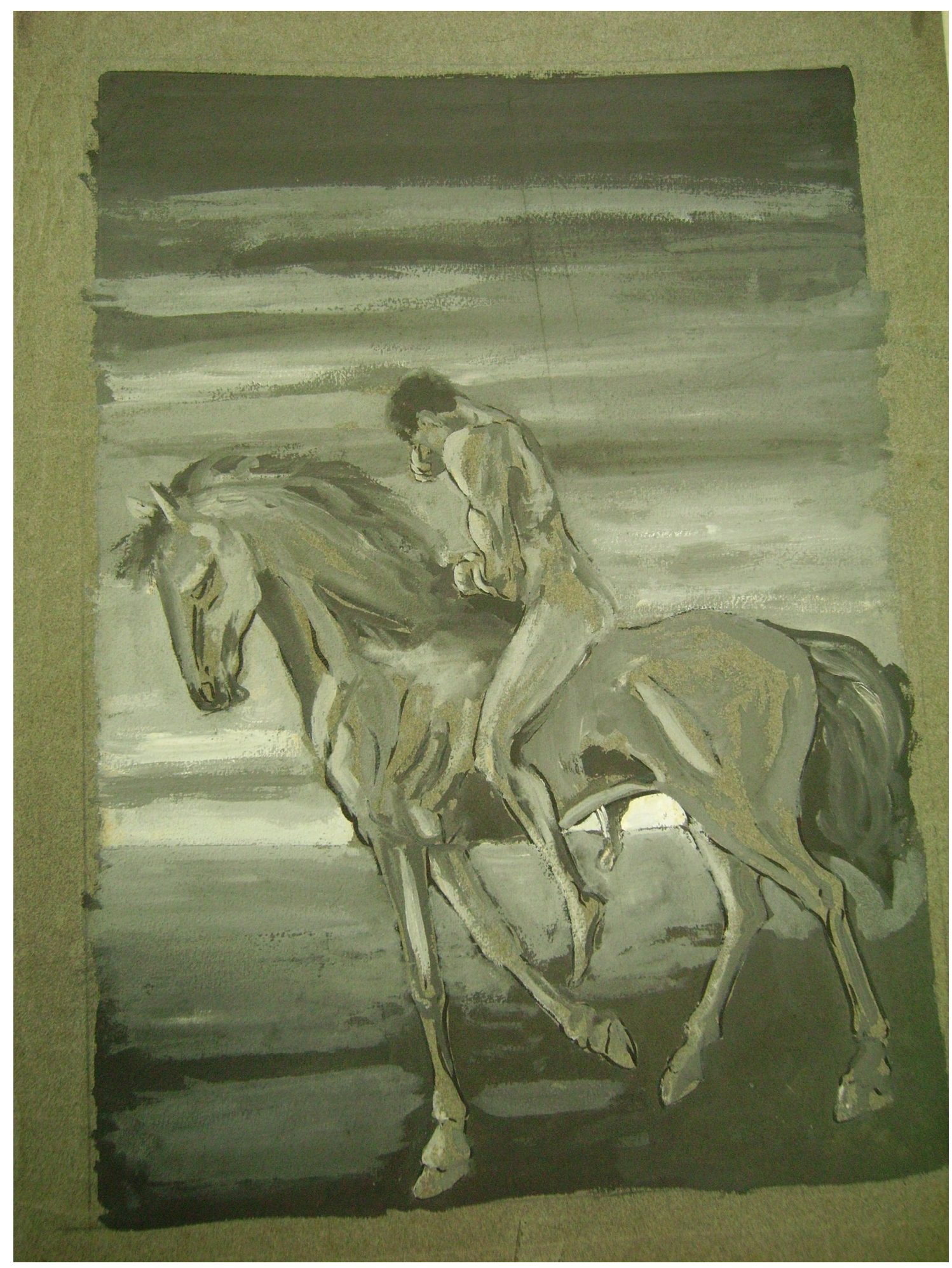

Cornélio Penna - 1920

(Guache / papel; 0,350 × 0,250) 


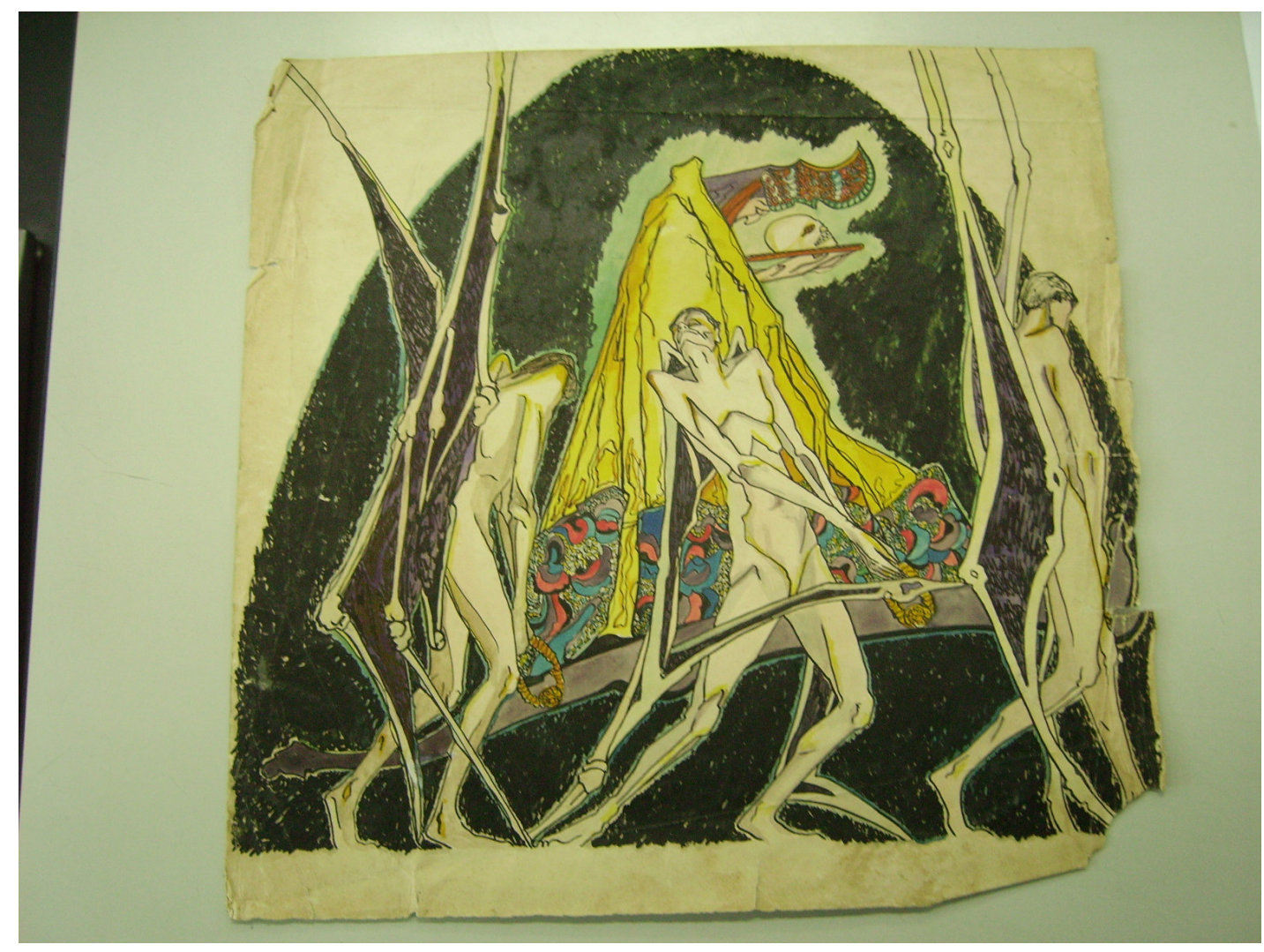

Cornélio Penna

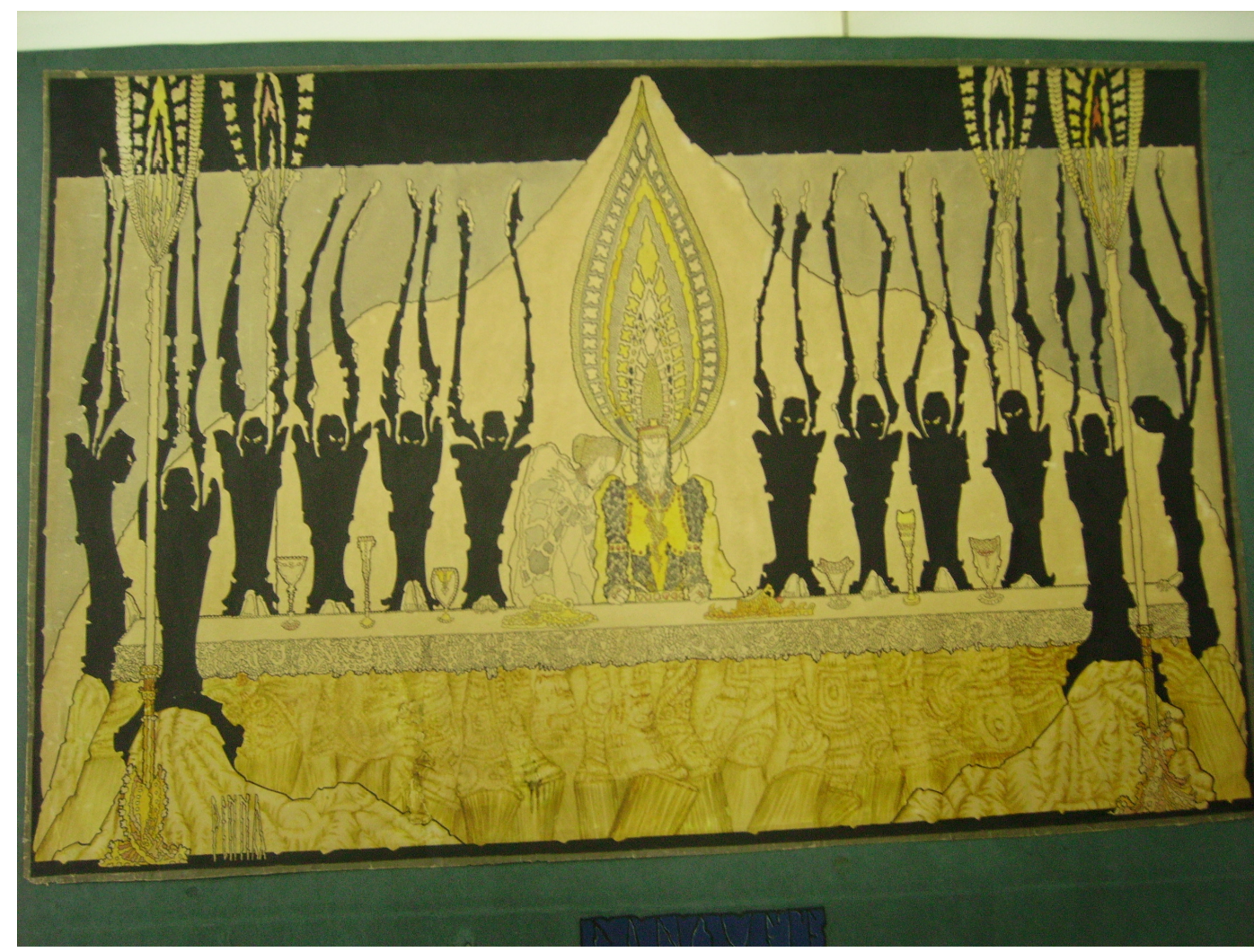

Cornélio Penna - Banquete (nanquim e aquarela / papel; 0,480 × 0,728) 


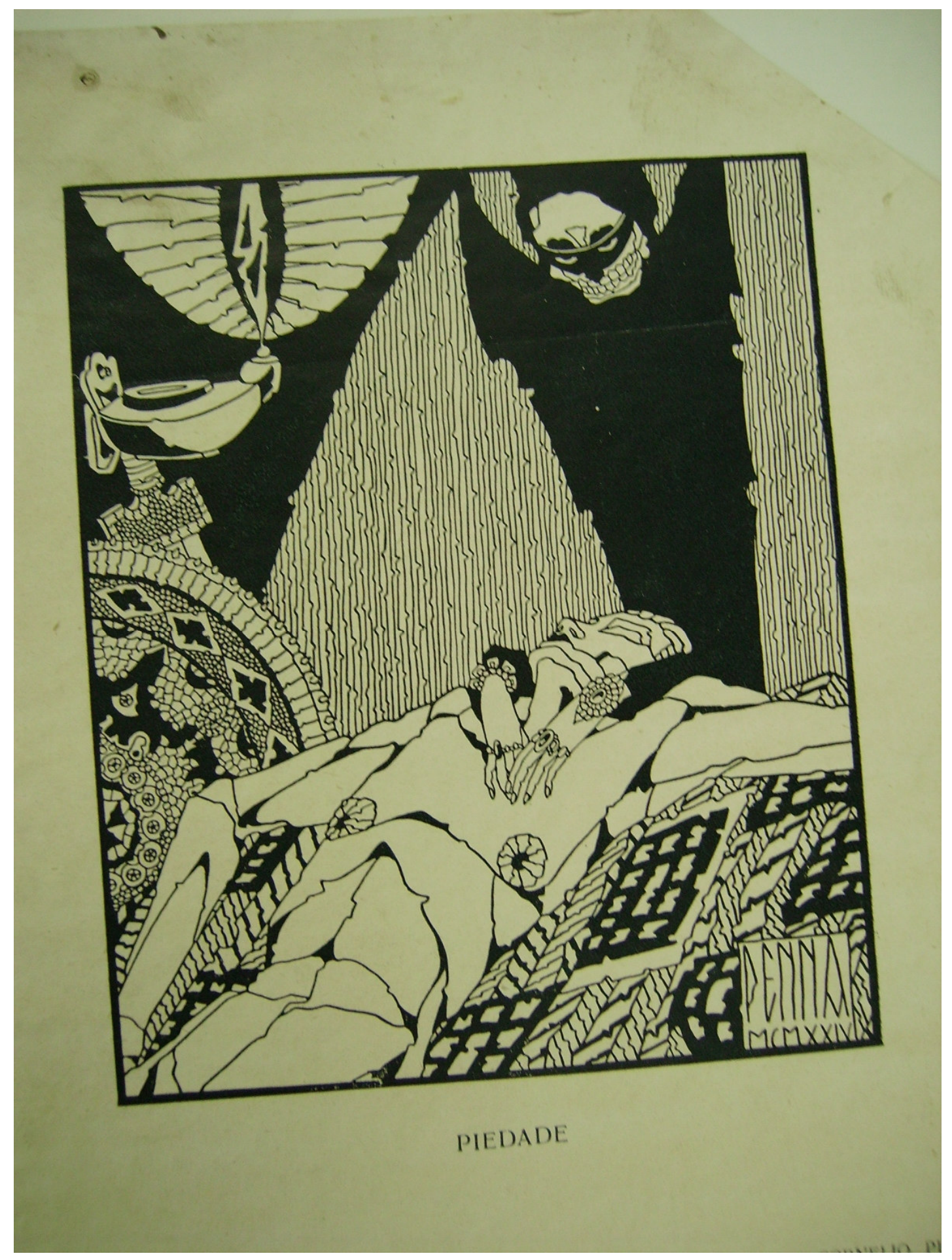

Cornélio Penna - Piedade - 1924 (ilustração para Terra de Sol, $n^{\circ} 4$ ) 


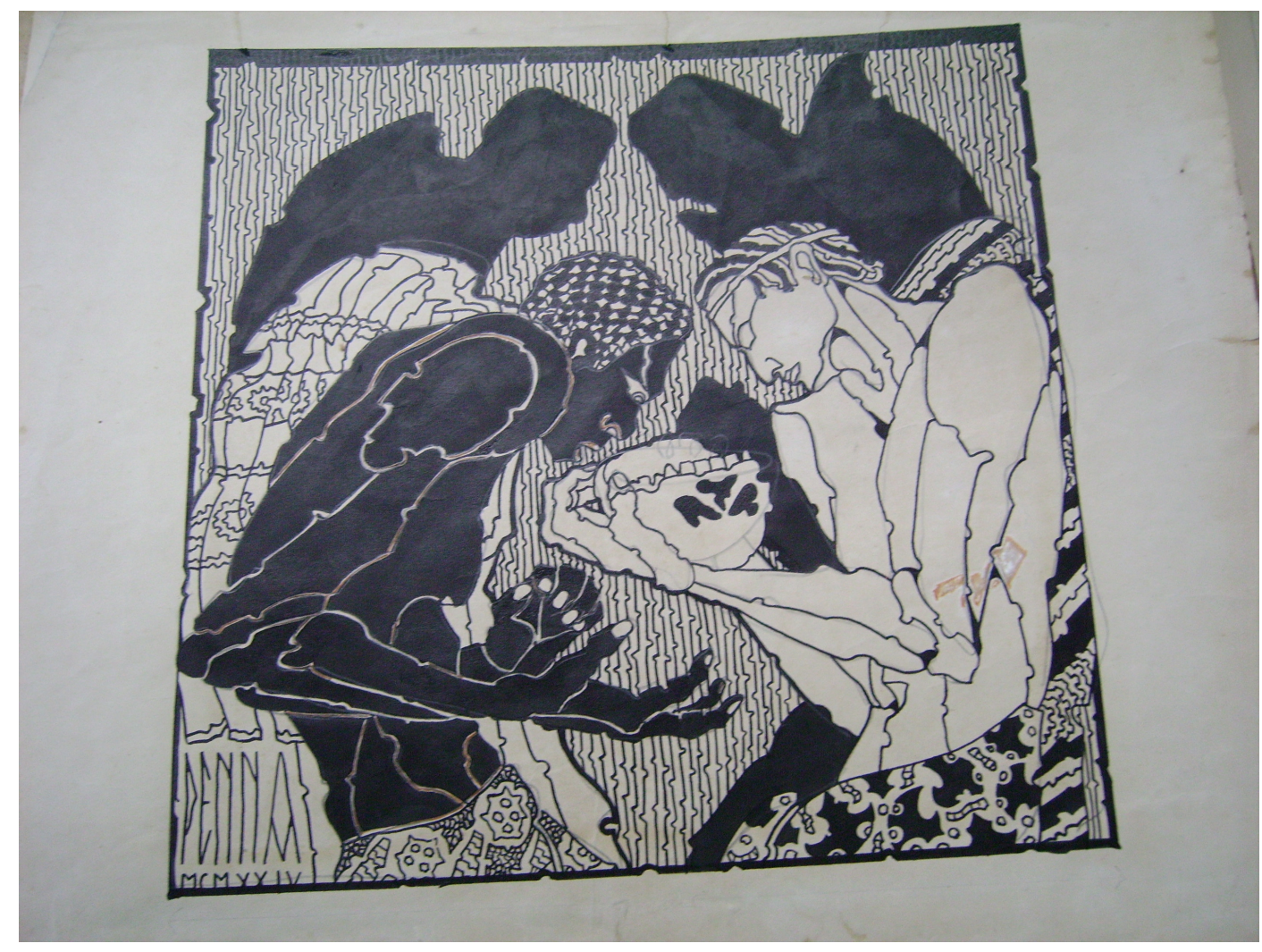

Cornélio Penna - 1924

(Nanquim / papel; 0,249 x 0,250)

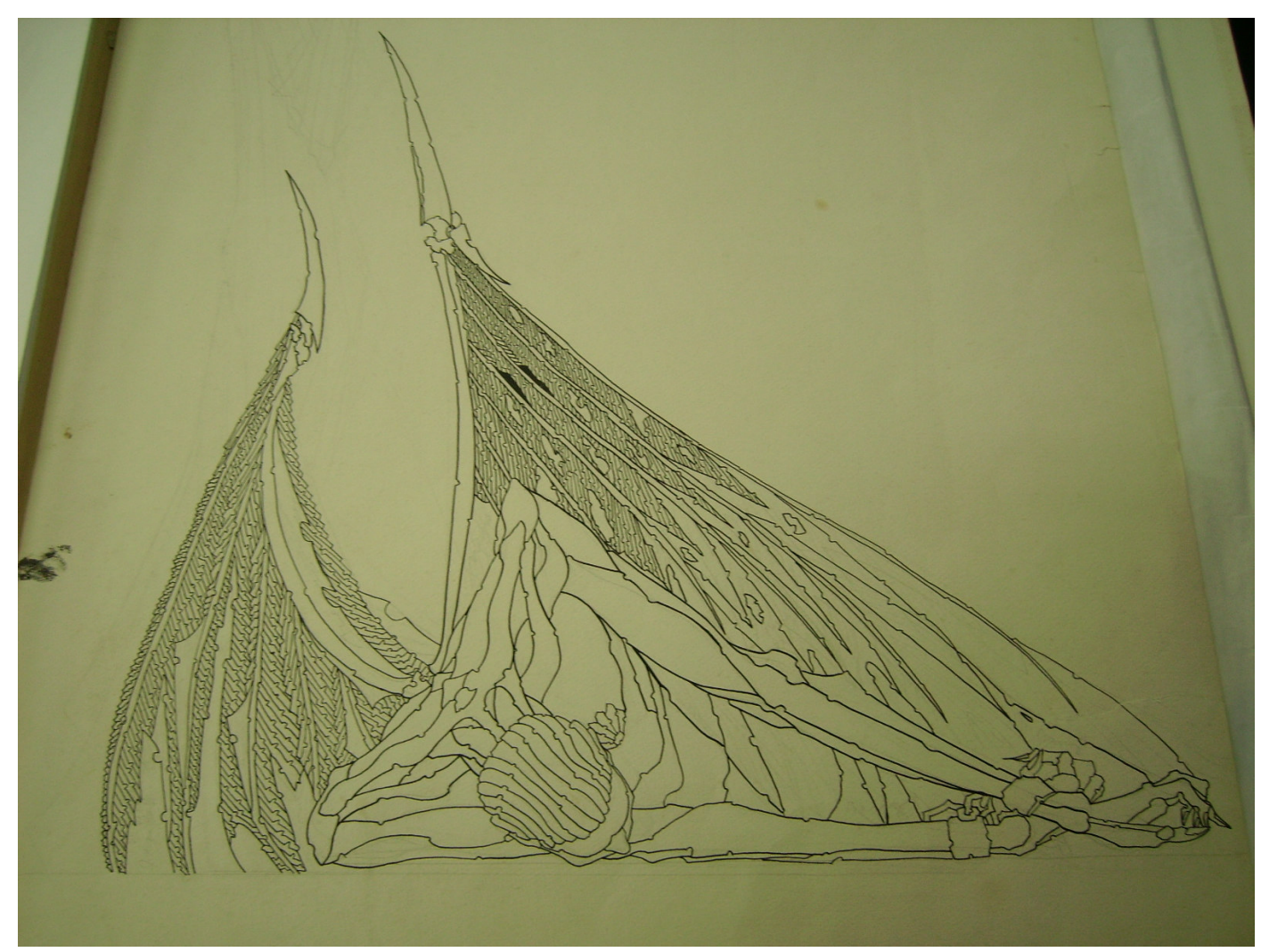

Cornélio Penna 


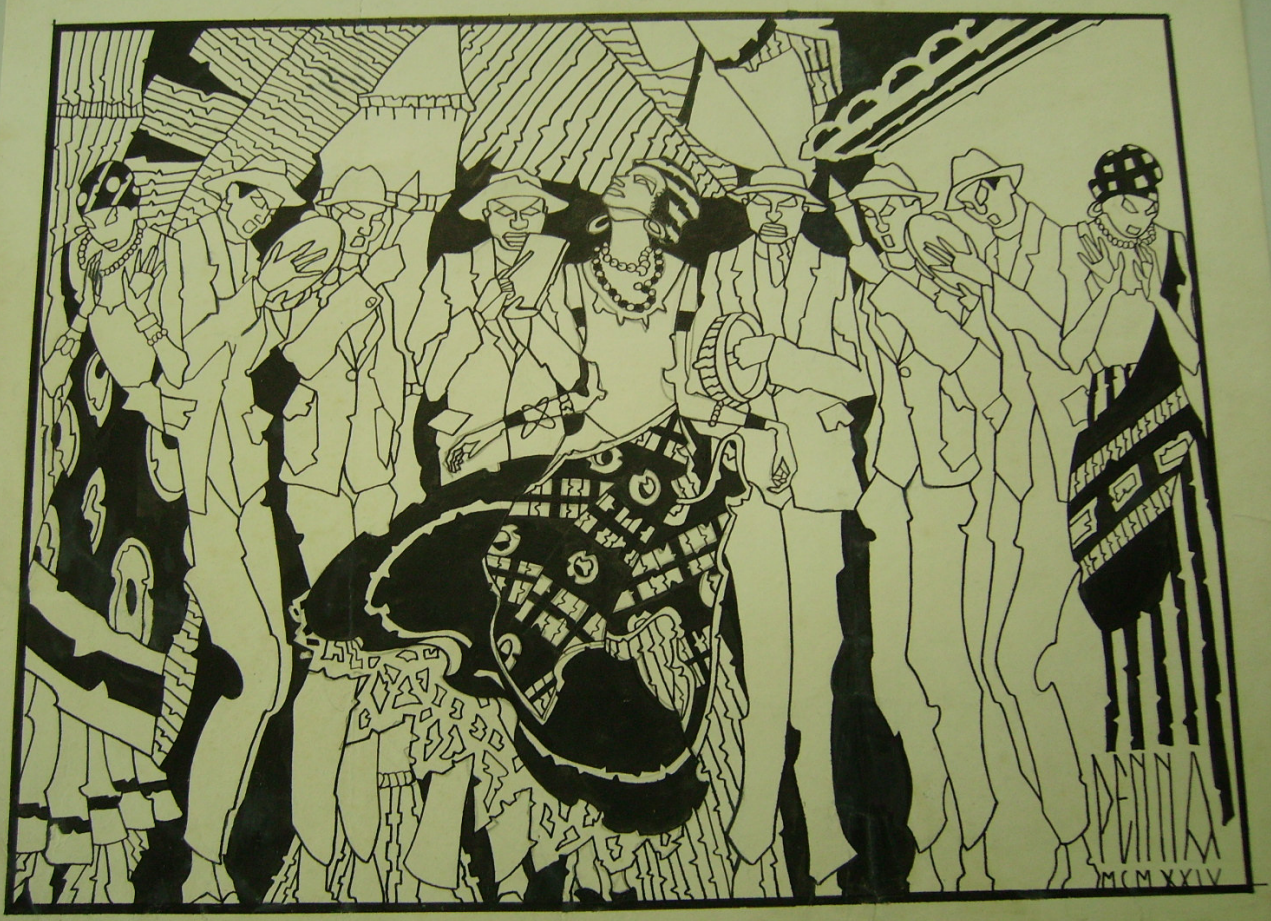

Cornélio Penna - 1924

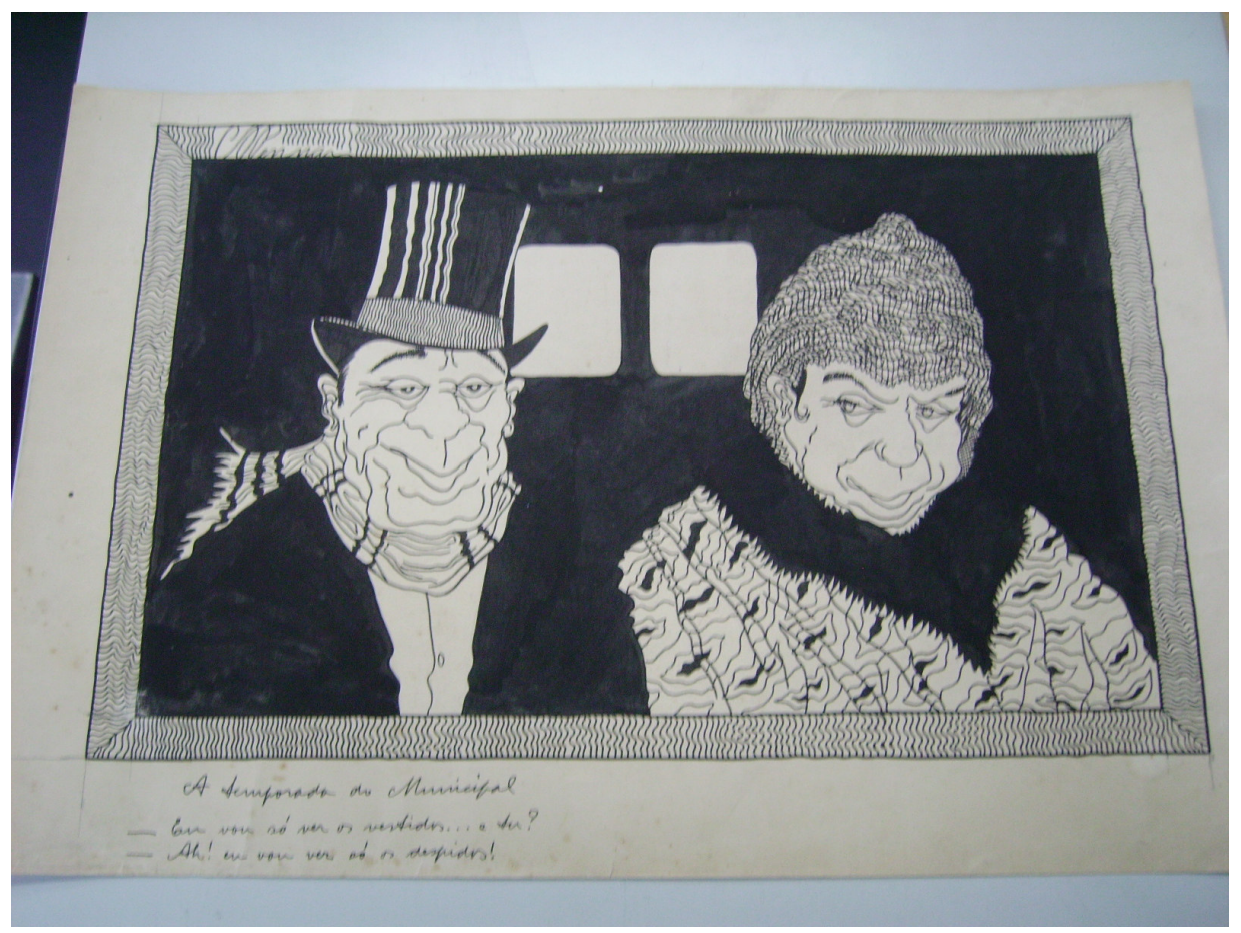

A temporada do Municipal

Cornélio Penna

- Eu vou só ver os vestidos... e tu?

- Ah! eu vou ver só os despidos! 